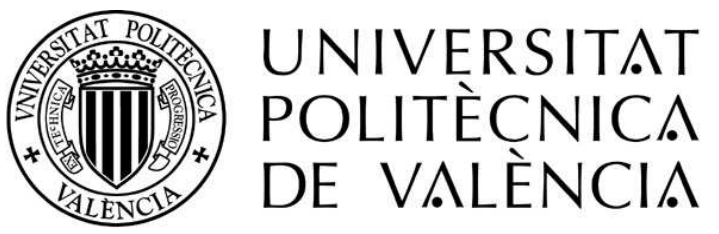

UNIVERSITAT POLITÈCNICA DE VALÈNCIA

FACULTAD DE BELLAS ARTES DE SAN CARLOS
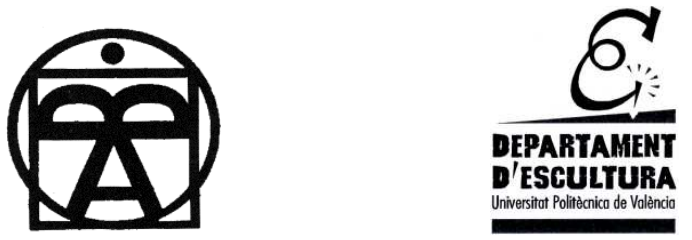

\title{
DE LA NATURALEZA DEL HOMBRE A LA
} NATURALEZA DE LA

OBRA DE ARTE. EL ARTE COMO CAMINO $Y$ VIDA, UNA REFLEXIÓN PREVIA AL SIGLO XX

\section{TESIS DOCTORAL}

Autora: LAURA PINILLA ZAPATER

Directora: Dra. CARMEN MARCOS MARTÍNEZ

Valencia, octubre 2015 

A mi familia y a mi directora de tesis por su apoyo $y$ paciencia. 



\section{AGRADECIMIENTOS}

Le doy las gracias a mi familia que me ha ayudado a seguir adelante en todo momento a pesar de las largas ausencias debido a las horas de estudio y frente al ordenador. Sin su esfuerzo y cariño no hubiera tenido la fuerza para realizar esta tesis.

También tengo mucho que agradecer a mi tutora Carmen Marcos por apoyarme y guiarme en la realización de la misma, por sus conocimientos, sus consejos, implicación y sobre todo por su persona.

Estoy contenta y agradecida con el "Universo" en general por haber podido estudiar Bellas Artes que fue una gran experiencia para mí, y ahora darme la posibilidad de realizar esta tesis. 



\section{RESUMEN}

La tesis titulada De la naturaleza del hombre a la naturaleza de la obra de arte. El arte como camino y vida, una reflexión previa al siglo XX, está concebida como un camino que comienza en el análisis y el estudio del hombre como naturaleza y parte de un Todo, hasta finalizar con una visión más subjetiva donde hemos dotado de vida a un proceso artístico como es la fundición artística a la cera perdida con molde de cáscara cerámica para crear una conexión entre el proceso nombrado y el ciclo vital de la mariposa.

No sólo se trata de encontrar los puntos de conexión actualmente casi invisibles entre el hombre y naturaleza, sino que basándonos en el hombre como ser artista desde su aparición en el planeta, hemos pretendido dotar de vida la obra de arte al albergar ésta los pensamientos, sentimientos y vivencias de su creador, convirtiéndose en una prolongación del artista. Por tanto, los procesos artísticos utilizados para crear estas obras artísticas también estarán dotados de naturaleza, pudiéndose llevar a cabo esa comparativa poética nombrada anteriormente. Además se convierten en caminos o canales por los que transitan esos sentimientos, miedos, vivencias y deseos del artista.

Basándonos en esta idea, hemos estudiado al hombre como naturaleza y hemos traspasado los límites de Occidente y nos hemos adentrado en la filosofía y el arte de Oriente antes de la era de la globalización.

El estudio de la vida y la obra de; Joseph Beuys, Giuseppe Penone y Wolfgang Laib por el sentimiento que vuelcan en sus creaciones y la fuerza visual y espiritual que éstas poseen, nos han servido de modelo para una mejor comprensión a la hora de dotar de vida la obra de arte.

La elección de la comparativa poética entre el proceso de fundición artística a la cera perdida y el proceso natural del ciclo vital de la mariposa es una elección intuitiva: ambos nos han atraído, por su fuerza, complejidad y belleza, además de ser un reto en cuanto que hay un choque visual entre la delicadeza, la ligereza, lo efímero y la fragilidad de la mariposa frente a la solidez, fuerza, peso y eternidad del bronce. 



\section{RESUM}

La tesi titulada De la naturalesa de l'home a la naturalesa de l'obra d'art. $L$ 'art com a camí $i$ vida, una reflexió prèvia al segle $X X$, està concebuda com un camí que comença en l'anàlisi i l'estudi de l'home com a naturalesa i part d'un Tot, fins a finalitzar amb una visió més subjectiva on hem dotat de vida un procés artístic, com és la fosa artística a la cera perduda amb motle de corfa ceràmica, per a crear una connexió entre el procés esmentat i el cicle vital de la papallona.

No sols es tracta de trobar els punts de connexió, actualment quasi invisibles, entre l'home i naturalesa, sinó que, basant-nos en l'home com ser artista des de la seua aparició en el planeta, hem pretés dotar de vida l'obra d'art, perquè abraça els pensaments, sentiments i vivències del seu creador, i es convertix en una prolongació de l'artista. Per tant, els processos artístics utilitzats per a crear estes obres artístiques, també estaran dotats de naturalesa, i es podrà dur a terme eixa comparativa poètica esmentada anteriorment. A més es convertixen en camins o canals pels quals transiten eixos sentiments, pors, vivències i desitjos de l'artista.

Basant-nos en esta idea, hem estudiat l'home com a naturalesa, hem traspassat els límits d'Occident i ens hem endinsat en la filosofia i l'art d'Orient abans de l'era de la globalització.

L'estudi de la vida i l'obra de Joseph Beuys, Giuseppe Penone i Wolfgang Laib pel sentiment que bolquen en les seues creacions i la força visual i espiritual que estes posseïxen, ens han servit de model per a una millor comprensió a l'hora de dotar de vida l'obra d'art.

L'elecció de la comparativa poètica entre el procés de fosa artística a la cera perduda i el procés natural del cicle vital de la papallona, és una elecció intuïtiva: ambdós ens han atret, per la seua força, complexitat i bellesa, a més de ser un repte, ja que hi ha un xoc visual entre la delicadesa, la lleugeresa, l'efímer i la fragilitat de la papallona davant de la solidesa, força, pes i eternitat del bronze. 



\section{ABSTRACT}

The thesis entitled "From the nature of man to the nature of the work of art. Art as pathway and life, prior to the twentieth century thinking", is conceived as a journey that begins with the analysis and study of mankind as nature and as part of a whole, to finish with a more subjective view where we have given life to the artistic process of lost wax smelting with ceramic shell, to create a connection between the mentioned process and the life cycle of the butterfly.

The question is not just finding the connection points between mankind and nature that are now almost invisible, but based on the man as an artist since his appearance on the planet, we have tried to enliven the artwork to hold this thought, feelings and experiences of its creator, becoming an extension of the artist. Therefore, the artistic processes used to create these artistic works will also be endowed with nature, being able to carry out the comparative poetics mentioned above. Besides they become paths or channels through which those feelings, fears, experiences and wishes of the artist go through.

Based on this idea, we have studied mankind as nature and we have gone beyond the limits of the western world entering the philosophy and art of the East before the era of globalization.

The study of the life and work of Joseph Beuys, Giuseppe Penone and Wolfgang Laib have been used as a model for a better understanding when it comes to give life to a work of art because of the feelings expressed in their creations and the visual and spiritual strength they have.

The choice of the poetic comparison between the artistic lost wax smelting process and the natural life cycle of the butterfly is an intuitive choice: they have both attracted us because of the strength, complexity and beauty, as well as being a challenge since there is a visual collision between delicacy, lightness, the ephemeral and the fragility of a butterfly when facing the solidity, strength, weight and eternity of bronze. 

DE LA NATURALEZA DEL HOMBRE A LA NATURALEZA DE LA OBRA DE ARTE. EL ARTE COMO CAMINO Y VIDA, UNA REFLEXIÓN PREVIA AL S. XX. 



\section{ÍNDICE}

INTRODUCCIÓN.

1. El Hombre Uno con la Naturaleza ..................................... 23

1.1. Filosofía oriental. I Ching. "El Libro de las Mutaciones"...... 31

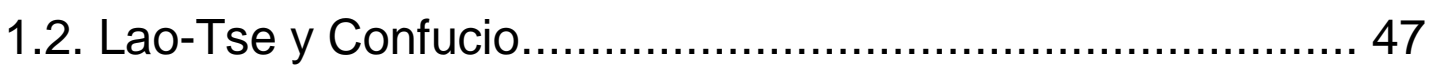

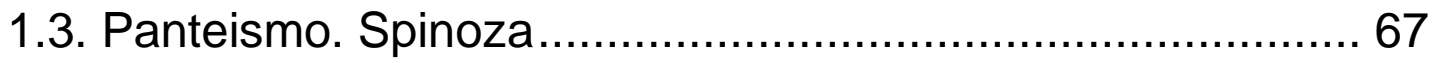

2. Concepto propio de hombre-naturaleza basado en el estudio de la obra de Gaston Bachelard, Mircea Eliade y

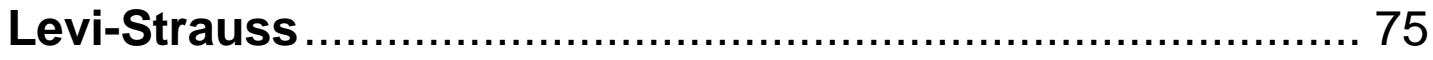

3. La naturaleza del "hombre-artista". Comparación entre

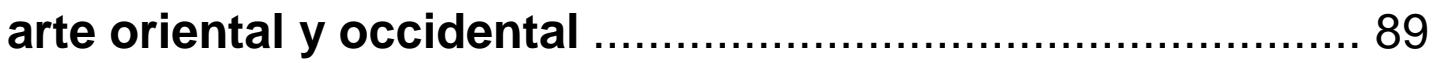

3.1. Arte como camino ..................................................... 101

3.2. Arte como proyección personal ..................................... 113

4. La obra de arte poseedora de vida y prolongación

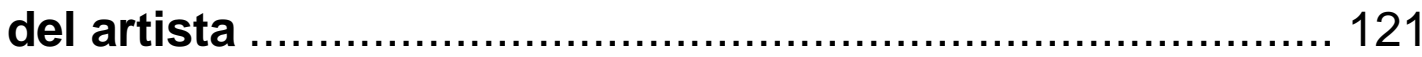

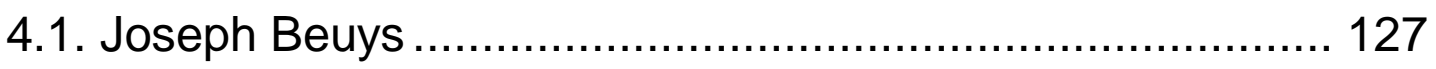

4.1.1. "I like America and America likes me".

("Me gusta América. Le gusto a América")...................................... 133

4.1.2. "Cómo explicar cuadros a una liebre muerta"........................ 137

4.1.3. "Bomba de miel en el lugar de trabajo".................................. 139

4.2. Giuseppe Penone ................................................... 145

4.2.1. "Piedra, cuerda, árbol, sol/Piedra, cuerda,

árbol, lluvia" 
4.2.2. “Ser río" ("Essere fiume”).................................................... 154

4.2.3. "Repetir el bosque" (Ripetere il bosco").............................. 157

4.2.4. "Soplo de hojas" ("Soffio di foglie") ......................................... 160

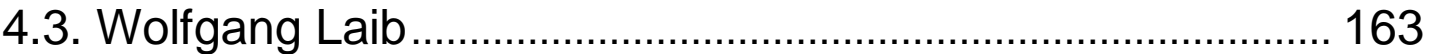

4.3.1. "Piedra de leche" ("Milkstone") ............................................. 170

4.3.2. "Platos de arroz" ("Rice Meals")........................................... 172

4.3.3. "Polen de avellano" ("Pollen from Hazelnut")......................... 174

4.3.4. "Cámara de cera" ("Wax Chamber")..................................... 177

5. Metamorfosis en el proceso creativo: una comparación poética entre el ciclo vital de la mariposa y el proceso de fundición artística a la cera perdida..................................... 181

5.1. El ciclo vital de la mariposa........................................... 183

5.2. El proceso de fundición artística a la cera perdida............ 197

5.3. Comparación poética entre el ciclo vital de la mariposa

y el proceso de fundición artística a la cera perdida ................ 219

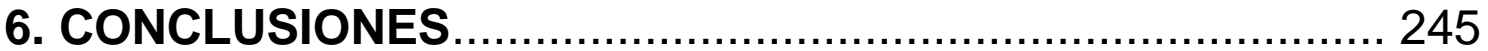

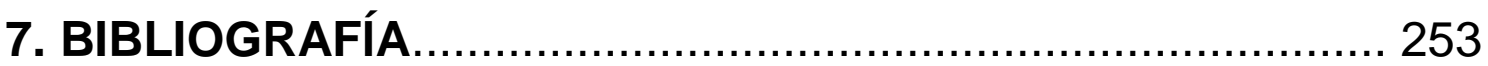

8. ÍNDICE DE ILUSTRACIONES ......................................... 261

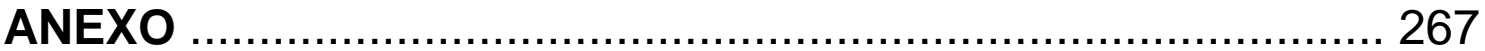




\section{Introducción}


El tema que abordamos, el hombre como naturaleza y la obra de arte como poseedora de vida por ser una prolongación del hombre-artista, en la actualidad, quizás parezca algo banal y de un tratamiento inferior al que nos merecemos debido al antropocentrismo que nos envuelve, y también por nuestro ego que nos hace creernos superiores. Tratar al hombre como uno especie más de la naturaleza, unificarlo y hablar de hermandad con el resto de seres vivos, equipar nuestra existencia con los fenómenos atmosféricos, los astros, el universo y hablar de buscar una unificación para alcanzar y formar parte de un Todo, no es algo nuevo. Intentar dejar de ver la obra de arte como un mero objeto decorativo, para darle vida por medio de los sentimientos, esperanzas y energía que el hombre-artista le ha transmitido al realizarla y unificarla con el universo y lo espiritual, es una visión que en Oriente ha arraigado durante largo tiempo.

Esta tesis, partía de una idea que nació en el taller de fundición artística tras observar este proceso creativo y poder participar activamente en su desarrollo. Contemplar la belleza, la fuerza, la energía, que se desprendía de cada fase de realización, pero sobre todo, en el momento de la colada en bronce, donde el aumento de temperatura, el olor, el color incandescente del metal, su densidad... era como estar presenciando algo mágico, impactante y sublime, nos adentró en un pensamiento en el que la idea del bronce como algo sólido, pesado, frío y eterno, desaparecía frente a una imagen vivaz, ligera, fluida y atemporal. Este cambio conceptual del metal, podía darse gracias a un proceso artístico que le permitía y le transfería la energía necesaria para realizar esa transformación. Una idea nos llevó a otra y sin darnos cuenta estábamos plasmando en un trabajo de investigación esa visión poética y subjetiva que nos había transmitido el proceso de fundición artística a la cera perdida. No fue fácil plasmar en papel esas ideas intangibles que aparecen como sensaciones y se alojan en nuestro pensamiento como una vía de estudio y desarrollo. Para ello, necesitábamos de un proceso natural, y el elegido fue el ciclo vital de la mariposa, por su complejidad, belleza y por la fragilidad y delicadeza del ser que emerge de la crisálida en contraposición a la dureza y frialdad aparente de la pieza de bronce. Una vez comenzado nuestro estudio, decidimos ir a la raíz de esta apropiación de "vida" de la pieza y 
llegamos a la conclusión, que todo comienza en el ser que la realiza que es el hombre-artista. Basándonos en esta idea, la tesis se transforma en una especie de camino que recorrer en el que cada apartado nos acerque más a la idea del hombre-artista como parte de la naturaleza, la obra de arte como poseedora de vida y prolongación de su creador y los procesos artísticos por tanto, se transforman en procesos naturales por ser el nexo de unión entre uno y otro.

Por tanto, nuestra hipótesis de investigación se basa en que variando el concepto que poseemos actualmente del hombre, obtendremos una nueva visión del arte basada en el espíritu natural del hombre-artista plasmando y formando parte de su obra, convirtiéndose los procesos creativos en nexos de unión cargados de naturaleza entre la obra de arte y su creador. Esto, nos permitirá crear una comparación poética entre un proceso natural y un proceso artístico.

Para ello, realizaremos un estudio sobre el lugar que ocupa el ser humano con relación a la madre naturaleza. Trataremos de encontrar los lazos perdidos entre ambos, evidenciando que el ser humano es una especie más del planeta, y que pertenecemos y formamos parte de un Todo que necesita de un equilibrio y un respeto mutuo para seguir existiendo. Una vez queda de manifiesto el lugar que le corresponde al hombre en su existencia, ampliaremos la investigación para centrarnos en el hombre-artista y su obra. Se trata de realizar un estudio donde quede reflejado cómo esa naturaleza pasa a formar parte de la obra de arte porque ésta no es ni más ni menos que la prolongación del artista, tanto conceptualmente, como sentimentalmente, como energéticamente.

Por tanto, los procesos artísticos realizados para llevar a cabo esas obras de arte, también estarán dotados de naturaleza, pudiéndose crear una comparativa entre un proceso, como es el proceso natural del ciclo vital de la mariposa, con el proceso artístico de fundición artística a la cera perdida, creando así una analogía poética.

El estudio de diversas fuentes bibliográficas ha sido clave en la realización de esta tesis como son: el I Ching. "El Libro de las Mutaciones" que nos ha aportado una gran visión espiritual y filosófica de Oriente y de la vida en 
general. Además nos ha adentrado en el concepto de Yin y Yang, donde hemos podido comprobar que nada puede ser cien por cien en su totalidad, porque su contrario, en mayor o menor medida, siempre habita en él; no existe el bien sin el mal, el día sin la noche, la luz sin la oscuridad... y cómo esa fuerza de opuestos es la que mueve el mundo. Otro libro que nos ha servido de guía en el desarrollo de la tesis es el "Tao Te Ching" escrito por el maestro LaoTse. Su estudio nos ha acercado al concepto del Tao, que suele traducirse por camino. Quien consiga vivir conforme el Tao, podrá alcanzar la inmortalidad, no desde la idea de no morir nunca, sino de vivir en un presente continuo donde no exista ni pasado ni futuro.

También hemos estudiado las creencias indígenas (hombre-naturaleza), mediante una carta escrita por el jefe indio Noah Sealth en 1854 y hemos recurrido a grandes pensadores como Gaston Bachelard, Mircea Eliade o LeviStrauss, para obtener una visión personal del hombre, basada en sus estudios.

El libro del "Psicoanálisis del fuego" y "La poética del espacio" de Gaston Bachelard entre otros ha sido de gran ayuda para poder plasmar nuestra visión poética al realizar la comparativa entre el proceso artístico de fundición a la cera perdida y el ciclo vital de la mariposa.

Para tratar el tema de arte como prolongación del artista, hemos escogido a una serie de artistas muy relevantes para nuestro trabajo por la fuerza, la energía y la simbología que son capaces de transmitir con sus obras, como son; Joseph Beuys, Giuseppe Penone y Wolfgang Laib. Una vez llegados a este punto, donde hemos visto al Hombre como Naturaleza y la obra de arte poseedora de vida, queda dotar de esta energía vital al proceso creativo por ser el nexo de unión entre el ser natural y artista con su obra. Para ello, y con la idea de unificar los procesos naturales con los procesos artísticos, hemos realizado una comparativa, subjetiva y poética, entre el ciclo vital de la mariposa y el proceso de fundición artística a la cera perdida.

La estructura de la tesis viene dada por una serie de capítulos y subapartados a desarrollar, ayudando así a una mejor comprensión por parte del lector. 
El primer capítulo, trata del hombre como naturaleza. Se encuentra dividido en tres subapartados. En él, hemos comentado la carta del jefe indio Noah Sealth en el año 1854 donde nos da una lección sobre quiénes somos y el respeto que hay que tener por la naturaleza. También nos hemos adentrado en la filosofía china, por medio del estudio de uno de los libros más importantes e influyentes de Oriente como es, el I Ching. "El Libro de las Mutaciones". Dos grandes maestros orientales que basaron sus enseñanzas en este libro como son Lao-Tse y Confucio, también serán analizados en este capítulo. Las filosofías que nacieron a raíz de sus enseñanzas, el taoísmo y el confucionismo, también serán objeto de estudio por poseer esos nexos de unión con la naturaleza, esa espiritualidad y la conciencia de que formamos parte de un Todo.

También aparece en este primer capítulo una visión más occidental por medio del estudio del Panteísmo y las ideas de uno de los filósofos más representativos de este periodo, Spinoza. Su idea de Dios, un Dios que nada tienen que ver con un ser único, sino que es la unificación de naturaleza, Dios y universo.

En el segundo capítulo hemos tratado de desarrollar un concepto de hombre-naturaleza propio basado en los estudios de tres grandes investigadores del ser como son Gaston Bachelard, Mircea Eliade y Levi-Strauss.

El tercer capítulo está basado en una comparativa entre las diferencias del arte oriental y el occidental, marcadas principalmente por su filosofía. Consta de varios subapartados. El primero de ellos, trata del arte como camino, basándonos en un estudio más filosófico del arte oriental frente al occidental. El segundo por el contrario, está basado en la proyección personal, que recae más en el arte occidental en cuanto que busca un reconocimiento y una autoría más notable. Recordemos que estamos refiriéndonos a antes de la era de la globalización.

El cuarto capítulo es un estudio de la obra de arte como prolongación del artista y poseedora de vida. Para una mejor comprensión de este capítulo, lo hemos dividido en tres subapartados dedicados cada uno a desarrollar y a analizar la obra de tres grandes artistas como son Joseph Beuys, Giuseppe 
Penone y Wolfgang Laib. La elección de estos artistas se debe a la fuerza visual, simbología, pasión y espiritualidad que poseen y transmiten sus obras.

Para una mayor comprensión de nuestra visión de la tesis, en este capítulo también analizaremos algunas de ellas.

El quinto capítulo, es una conexión poética basada en una comparativa entre el proceso de fundición artística a la cera perdida y el ciclo vital de la mariposa. Bajo una mirada subjetiva, trataremos de equiparar ambos procesos. Todo ello, con la idea de llegar a plasmar en papel la visión del proceso artístico como un camino, que une al hombre-artista con la obra de arte, por el que transitan las emociones, sensaciones, miedos, experiencias y vivencias del artista.

Para llegar a esa comprensión hemos explicado los dos procesos nombrados anteriormente por separado, para dar una visión al lector más ampliada y detallada de cada uno de ellos. $Y$ en el último subapartado, realizaremos esa conexión poética entre ellos, donde podremos comprobar que además de los puntos de unión que se puedan dar a simple vista, como por ejemplo la belleza de ambos procesos, existe toda una serie de conexiones ocultas que desvelaremos a lo largo del capítulo.

La tesis se cierra con las conclusiones, en las que hemos unificado pensamientos anteriores y posteriores a la realización del trabajo. Es un camino que nos lleva mediante la reorganización de ideas, desde el lugar de donde partíamos, hasta el final de nuestra investigación. 
1. El Hombre Uno con la Naturaleza 
En la época actual donde la técnica y la industria ocupan un puesto destacado en nuestra sociedad, donde el capitalismo y el afán por triunfar ocupan gran parte del pensamiento del ser humano, la visión de que el Hombre proceda de la naturaleza o sea una especie más de ella es prácticamente nula.

Gracias a la evolución, el ser humano ha pasado de ser nómada y habitar en cuevas a vivir asentado en grandes poblaciones. Ha pasado de ir desnudo a cubrir su piel con prendas y complementos de vestir. Su manera de comunicarse ya no es tosca y ruda, sino que gracias al desarrollo del lenguaje y la escritura somos capaces de comunicarnos de una manera global. Se han perdido los hábitos de la caza y la recolección, actualmente sólo unos pocos se dedican al cultivo, la pesca o la ganadería, el resto obtenemos los productos alimentarios necesarios mediante la compra en comercios especializados. Las relaciones sociales que se creaban en torno a las hogueras cerca de las cuevas o en los bosques, se han transformado en reuniones sociales en locales, discotecas, bares..., donde no existe esa sensación de bienestar y tranquilidad que otorgaba el estar cerca del fuego, porque las luces, el ruido y la aglomeración de gente, lo impide.

Las funciones del ser humano, también han sido trastocadas con el paso del tiempo. Antiguamente los hombres eran los que se encargaban de cazar, de pescar y de realizar las tareas de fuerza, mientras las mujeres recolectaban y se encargaban de la crianza de sus hijos. En la época actual existe una necesidad creada por la sociedad donde ambos progenitores deben de trabajar fuera del hogar, incluso cuando no puedan hacerse cargo de su propia progenie, legando su alimentación y gran parte de su educación a terceras personas.

La evolución del ser humano le ha permitido crear una serie de avances técnicos, industriales y científicos que han creado una brecha cada vez mayor entre el Hombre y su naturaleza.

La búsqueda de la felicidad que nos planteaba Aristóteles, ahora está basada en el consumismo y el poder. El Hombre está tan manipulado psicológicamente que en la mayoría de los casos no se da cuenta que esa realidad ficticia en la que se basa el mundo, no nos hace felices. Sólo hay que prestar 
atención a nuestro cuerpo para saber que hemos olvidado parte de nosotros en el camino. El afán de ser la especie dominante y separarnos del resto de seres vivos, nos está negando algo tan importante como nuestros instintos. No prestamos atención a nuestro cuerpo porque culturalmente nos han enseñado a no hacerlo, pero todos tenemos en el fondo de nuestro ser la añoranza de la tierra, del aire puro, del contacto con plantas y animales. Por cultura vivimos en altos edificios, en apartamentos o pisos, y desde ellos sólo se vislumbran otras ventanas, otros balcones, otras paredes... respiramos un aire cargado y sólo alcanzamos a respirar aire puro si nos esforzamos por encontrarlo yendo a lugares apartados de la civilización, donde el tiempo parece ralentizarse, sentimos la naturaleza entrando por nuestros poros y notamos cómo la paz y la tranquilidad nos envuelve. Sentimos que por primera vez en mucho tiempo formamos parte de algo, nos agrada y nuestra mente vuela y nos imaginamos en una casa en el campo con animales, un huerto y todo el tiempo del mundo para nosotros. Esa si es la felicidad real del ser humano, y no formar parte de una rutina diaria en la que trabajar y consumir es lo más importante, en la que el tiempo pasa tan deprisa que no nos damos cuenta ni del cambio de las estaciones.

Hemos olvidado de dónde provenimos y no sentimos respeto por la Madre Tierra. No queremos protegerla, cuidarla, respetarla... queremos dominarla. No nos damos cuenta que cada árbol que es talado, cada río que es secado, cada ser vivo que pierde la vida o es dañado se lleva con él parte de nosotros, porque formamos parte de un mismo Todo, y si no aprendemos a valorarnos y respetarnos, llegará el día en que nada existirá. Se romperá la unión del ser humano con el medio del que depende para subsistir, si éste es dañado el hombre también sufrirá las consecuencias.

El jefe indio Noah Sealth en el año 1854 escribió una carta como respuesta a la propuesta del presidente Franklin Pierce de comprarles sus tierras y "crear una reserva india para acabar con los enfrentamientos entre indios y blancos". Ésta, se ha convertido en el primer manifiesto ecologista, en defensa de la naturaleza.

\footnotetext{
${ }^{1}$ www.waste.ideal.es/sealth.htm (14/12/12 a las 9:30h).
} 
Algunos fragmentos que podemos encontrar en ella son:

"Los ríos son nuestros hermanos y sacian nuestra sed; son portadores de nuestras canoas y alimentan a nuestros hijos. Si les vendemos nuestras tierras, ustedes deben recordar y enseñarles a sus hijos que los ríos son nuestros hermanos $y$ también los suyos, y por lo tanto, deben tratarlos con la misma dulzura con que se trata a su hermano".

- $\quad$ "Sabemos que el hombre blanco no comprende nuestro modo de vida. El no sabe distinguir entre un pedazo de tierra y otro, ya que es un extraño que llega de noche y toma de la tierra lo que necesita. La tierra no es su hermana, sino su enemiga y una vez conquistada sigue su camino, dejando atrás la tumba de sus padres sin importarle. Le secuestra la tierra de sus hijos. Tampoco le importa. Tanto la tumba de sus padres, como el patrimonio de sus hijos son olvidados. Trata a su madre, la Tierra, y a su hermano, el firmamento, como objetos que se compran, se explotan y se venden como ovejas o cuentas de colores".

- ¿Qué sería del hombre sin los animales? Si todos fueran exterminados, el hombre también moriría de una gran soledad espiritual; porque lo que le sucede a los animales también le sucederá al hombre. Todo va enlazado".

- "Enseñen a sus hijos que nosotros hemos enseñado a los nuestros que la tierra es nuestra madre. Todo lo que le ocurra a la tierra le ocurriría a los hijos de la tierra. Si los hombres escupen en el suelo, se escupen a sí mismos. Esto sabemos: la tierra no pertenece al hombre; el hombre pertenece a la tierra; Esto sabemos. Todo va enlazado, como la sangre que une a una familia. Todo va enlazado,?

La fuerza y sabiduría de sus palabras no sólo ha traspasado fronteras llegando a todos los puntos del planeta, sino que ha perdurado en el tiempo y sus palabras todavía siguen vigentes. Esa fusión que se plantea del hombre con la naturaleza es pura, mística, lógica. La carta nos acerca a nuestro yo interior y nos hace plantearnos cuestiones tan profundas como el origen de nuestra existencia, la unión del hombre con el medio en el que vive y necesita para su supervivencia y la unión de destinos entre todo lo que existe. Ante esta unión, el ser humano debe de sentirse en igualdad con el resto de seres vivos, lo que actualmente es una visión muy alejada de nuestro antropocentrismo.

Desde la creación y dominio de la tecnología la visión del hombre ante la naturaleza ha variado. La capacidad de entender, controlar e incluso adelantarse a los fenómenos naturales, hacen que el ser humano se sienta superior al resto de seres vivos y pierdan el respeto sagrado por la naturaleza.

\footnotetext{
${ }^{2}$ Fragmentos de la carta del jefe indio Noah sealth, 1.854 www.waste.ideal.es/seath.htm (14/12/12 a las 9:30h).

La carta completa se encuentra en el anexo de la tesis.
} 
En la filosofía oriental esta unión está muy presente sobre todo en el taoísmo, donde el ser no tiene una limitación clara y pasa a fundirse con la naturaleza. El origen de todo lo existente para ellos, se denomina Tao y el hombre debe de basar su vida en armonía con él.

La palabra Tao suele traducirse por camino. Es el camino que el hombre debe seguir en su vida, si una persona se sale del Tao deberá regresar a él para encontrar la paz interior y estar en armonía con todo lo que le rodea, pues si no lo hace nunca alcanzará la finalidad del taoísmo, una longevidad plena. El hombre debe de estar en armonía con la naturaleza para poder ser inmortal, entendiendo esta inmortalidad como una superación del propio individuo a nivel personal y colectivo frente a los cambios constantes en la vida humana.

Para los taoístas el universo se mueve gracias a las fuerzas opuestas y por tanto, nada es perpetuo siempre hay un cambio. De esta idea nace el yin y el yang, el bien no existe sin el mal, y el mal no puede existir sin el bien. Nada es cien por cien en su totalidad, siempre su opuesto forma parte de él en mayor o menor proporción, según el momento de cambio en que se encuentre. El yin es la fuerza pasiva, húmeda, oscuridad, sutil, nubosa, turbia, femenina, la tierra... y el yang es la fuerza activa, iluminada, concreta, clara, masculina, seca, penetrante, el cielo... el Tao es la energía superior que las abarca.

\section{Yin y Yang}

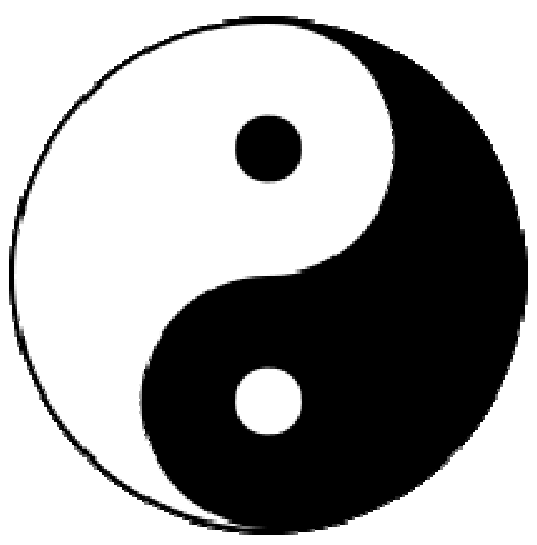

Ilustración 1. El taijitu, la forma más conocida de representar el concepto del yin y el yang (yīnyáng). 
En Oriente esta idea de orden universal donde todo se transforma constante e infinitamente, está presente en todos los ámbitos de la vida. Un ejemplo de ello puede ser el estilo de vida macrobiótica. Las personas que viven conforme a la Macrobiótica intentan vivir al compás del orden universal, es el camino a la longevidad. En griego, "macro" significa grande y "bios" significa vida. Gran parte de su creencia se basa en la alimentación, tanto física como espiritual. Según ellos, la dieta alimenticia tiene la capacidad de forjarnos el carácter y solo alimentándonos de una manera equilibrada con respecto al orden del universo, podremos alcanzarán la salud, la felicidad y la libertad que de otro modo nos es negada. Así, la persona que ingiera gran cantidad de proteína animal, será más agresiva que la que se alimente solo de vegetales. Una de las causas, es que la subida de adrenalina que el animal produce en el momento de su muerte pasa a formar parte del ser que la ingiere. Porque no hay que olvidar que todos los seres vivos pertenecemos a un mismo universo y el daño que inflijamos a otros en realidad nos lo estamos aplicando a nosotros mismos. 


\section{SUPLICA DIARIA PARA UN MUNDO EN PAZ}

Cuando comemos, comprendamos que somos obra del alimento que la naturaleza nos da por orden del universo infinito, y demos gracias por todo lo recibido.

Cuando conocemos gente, veámoslos como hermanos y hermanas y recordemos que todos hemos venido del infinito universo a través de nuestros padres y antepasados y recemos como Uno solo con toda la humanidad para obtener el amor universal y la paz en la Tierra.

Cuando contemplamos el sol y la luna, el cielo y las estrellas, las montañas y los ríos, los mares y los bosques, los campos y los valles, los pájaros, todos los animales y todas las maravillas de la naturaleza, recordemos que hemos venido con todos ellos desde el universo infinito. Estemos agradecidos por todo nuestro medio ambiente aquí en la Tierra y vivamos en armonía con todo lo que nos rodea.

Cuando vemos las granjas y los villorrios, los pueblos y las ciudades, las artes y culturas, las sociedades y las civilizaciones y todas las obras del Hombre, recordemos que nuestra creatividad ha surgido del universo infinito, pasada de generación en generación y diseminada sobre la faz de la Tierra. Estemos agradecidos por haber nacido sobre este planeta con inteligencia y sabiduría, y prometámonos todos realizar perpetuamente nuestro eterno sueño de Un Mundo en Paz a través de la salud, libertad, amor y justicia. ${ }^{3}$

\footnotetext{
${ }^{3}$ KUSHI, Michio. "El libro de la Macrobiótica". Ed. Sol Universal. Málaga. Primera traducción en español, 1979. Pag 6.
} 
La unión del hombre y la naturaleza es un tema vital en todas las zonas del planeta, no importa la época ni el momento social. Con el fin de desarrollar más profundamente este tema, hemos escogido como punto de partida dos de los maestros más influyentes de Oriente, Lao-Tse y Confucio.

También estudiaremos uno de los libros más importantes y antiguos de la filosofía china, el I Ching. "El Libro de las Mutaciones", basado en un universo regido por el cambio y la relación dialéctica de los opuestos. 


\subsection{Filosofía oriental.}

\section{Ching. "El Libro de las Mutaciones"}


El I Ching es uno de los libros más antiguos de China. Se cree que sus primeros textos están escritos hacia el 1.200 a.C. aunque si como se piensa Fu $\mathrm{Hi}$ es el inventor de los signos del libro, su antigüedad se remontaría a un periodo inmemoriable de la historia. Posteriormente el Rey Wen añadió breves sentencias, los Dictámenes, su hijo el duque de Chou realizó el texto de los trazos individuales y por último se cree que Kung Tse (Confucio) añadió el "Comentario para la Decisión" y el de las "Imágenes".

El libro nace con una visión taoísta basada en el cambio de fuerzas opuestas como motor del universo, aunque actualmente se le cataloga como uno de los Cinco Clásicos Confucianos.

Nace por parte de una cultura campesina, de la observación, el estudio y la comprensión de los fenómenos vitales que se producían y sus interacciones. Los sabios antiguos se dieron cuenta mediante el estudio, que todos ellos realizaban un movimiento cíclico, basado en el devenir de los opuestos.

Se dieron cuenta, que existía una especie de energía celestial que se depositaba en la Tierra, proveniente de todos los astros, satélites, planetas, galaxias... el Yang y una especie de energía que realizaba el camino inverso, proveniente del centro de la Tierra, el Yin. La primera, es una fuerza centrípeta y la segunda, es una fuerza centrífuga, ambas fuerzas se controlan mutuamente creando un equilibrio. De la unión de estas fuerzas surge la vida y sólo conociendo su funcionamiento podemos convertir la guerra en paz, el odio en amor, lo malo en bueno, la enfermedad en salud... y sólo así el Hombre será capaz de hallar el camino que debe seguir para estar en armonía con lo visible y lo invisible, con lo individual o lo colectivo, en definitiva, con el Todo.

Por tanto, el / Ching, basándose en estos estudios, intenta dar respuestas a las dudas de los hombres. El libro es un oráculo, que te indica el camino que debes seguir para no perderte en el sinuoso camino de la vida y actuar conforme a tu naturaleza, pero no de una manera impositiva, sino dándote las pautas para que cada persona se cree su propio destino.

El libro no sólo es un oráculo, también es un libro sapiencial, filosófico, moral y cosmogónico. Está basado en un sistema algebraico, una sucesión 
finita de signos que otorgan un sinfín de significados. Por tanto, su interpretación y aplicación es individual de cada persona. El libro como oráculo ayuda a quien lo consulta a conectarse con el Tao, y por tanto, le enseña el camino que debe seguir.

En uno de los escritos que se conocen como "Las Diez Alas" del / Ching, podemos leer:

- §1. "Los santos sabios de tiempos antiguos hicieron el Libro de las Mutaciones de este modo: para ayudar de manera misteriosa a las luminosas divinidades, inventaron el oráculo de los tallos de milenrama. Adjudicaron al cielo el número tres y a La Tierra el número dos y calcularon de conformidad los números siguientes. Contemplaron las modificaciones en lo oscuro y lo luminoso y establecieron de conformidad los signos. Engendraron movimientos en lo firme y lo blando e hicieron que de esta suerte se originaran las líneas individuales. Obraron en sí mismos la concordancia con el TAO y su VIRTUD* y de acuerdo con ello establecieron el orden de lo recto. Al penetrar con el pensamiento el orden del mundo externo hasta el fin, y la ley de su propia interioridad hasta el núcleo más profundo, arribaron a la comprensión del destino".

En un principio el libro era sólo de signos y su función era solo oracular, aunque se distanciaba mucho del resto de oráculos de la época ya que no sólo tenía el poder de contestar "si" o "no", sino que gracias a los ocho signos representados que actuaban como imágenes de lo que ocurría en el Cielo y la Tierra, se convertían en cambio y transición. Estos ocho signos, también llamados trigramas, se combinaron para formar 64 hexagramas, que a su vez se componen cada uno de seis trazos positivos y negativos.

- §5. Por eso existe en las Mutaciones el gran comienzo original. Éste engendra las dos fuerzas fundamentales. Las dos fuerzas fundamentales engendran las cuatro imágenes. Las cuatro imágenes engendran los ocho signos ${ }^{5}$.

Al principio del origen de todas las cosas, no existía la materia, todo era energía y ésta necesitaba de la unión de dos fuerzas fundamentales como son el Cielo y la Tierra, para materializarse. El Cielo correspondería a la parte Yang, lo luminoso, lo masculino, lo condicionante, lo creativo y vendría representado mediante un trazo continuo __ y la Tierra sería la parte Yin, lo oscuro, lo femenino, lo condicionado, lo receptivo y vendría representada por

\footnotetext{
${ }^{4}$ WILHEIM, Richard. I Ching. "El Libro de las Mutaciones". Versión del chino al alemán, con comentarios de Richard Wilheim. Traducción al español, con presentación y notas, por D. J. Vogelmann. Ed. Sudamericana. Buenos Aires, 2001. Pág. 349.

${ }^{5}$ WILHEIM, Richard. I Ching. "El Libro de las Mutaciones". Op. Cit. Pág. 406.
} 
un trazo dividido en dos partes iguales - Con la duplicación de estas dos fuerzas fundamentales surgen cuatro imágenes diferentes:

el Yang viejo o grande $=$ el Yin viejo o grande $=$ el Yang joven o pequeño $\Longrightarrow$ el Yin joven o pequeño, que corresponden a las cuatro estaciones del año. Mediante otro añadido de un trazo surgen luego los ocho signos o trigramas:

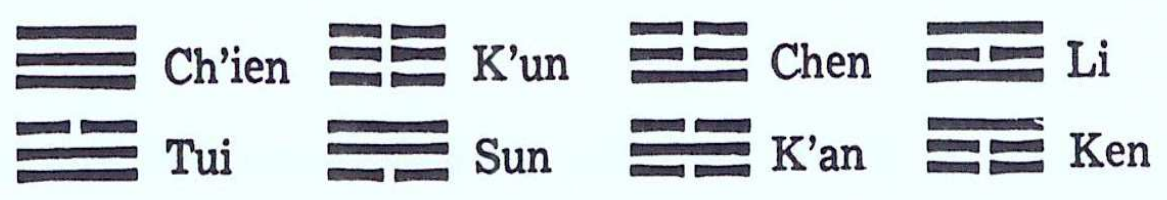

Ilustración 2. Cuatro imágenes iniciales que al añadirles un trazo más, se convierten en los ocho trigramas.

Estos ocho trigramas representan la transformación continua de todos los fenómenos. Los cuales, hacen mención al cielo (Ch'ien), la tierra (K'un), el agua (K’an), el fuego (Li), la montaña (Ken), el lago (Tui), el viento (Sun) y el trueno (Chen). De ellos, el Cielo y la Tierra, serían los progenitores. El viento y el trueno serían los hijos mayores, el fuego y el agua representarían a los hijos medianos y la montaña y el lago representarían a los hijos menores. Como he nombrado anteriormente, estos signos también poseen género, siendo el trueno, el agua y la montaña de género masculino y el fuego, el lago y el viento, de género femenino.

Estos ocho trigramas hacen mención a los cinco elementos o cinco transformaciones existentes en la cosmología oriental. Estos son, la Tierra, el Agua, el Fuego, la Madera y el Metal. En el / Ching, el elemento Tierra es representado por los trigramas Tierra (K'un) y Montaña (Ken), el elemento Agua es representado por el trigrama Agua ( $\left.K^{\prime} a n\right)$, el elemento madera es representado por los trigramas Viento (Sun) y Trueno (Chen) y el elemento Metal es representado por los trigramas Cielo (Ch'ien) y Lago (Tui) y el elemento Fuego es a su vez representado por el trigrama Fuego (Li). 
Los trigramas también indican dirección:

\begin{tabular}{|c|c|c|c|c|c|c|c|c|}
\hline Elemento & Metal & Metal & Fuego & Madera & Madera & Agua & Tierra & Tierra \\
\hline I Ching & Cielo & Lago & Fuego & Viento & Trueno & Agua & Montaña & Tierra \\
\hline Dirección & Noroeste & Oeste & Sur & Sureste & Este & Norte & Noreste & Suroeste \\
\hline Trigramas & $\equiv$ & 三 & I & $\equiv$ & : & $=$ & $\mathbf{\Xi}$ & $\mathbf{z}^{6}$ \\
\hline
\end{tabular}

Las imágenes representadas por los ocho signos o trigramas corresponden a estados de mutación, de cambio continuo, de transformación constante.

Es la duplicidad de estos ocho trigramas, la que nos lleva hasta los sesenta y cuatro hexagramas existentes en el I Ching. Cada uno de ellos se representa mediante seis trazos y hace mención a un cambio en la naturaleza. Estos cambios son cíclicos, como sucede con el día y la noche, el transcurrir de las estaciones, la vida y la muerte... y todo ello se basa en la dialéctica entre los opuestos. No puede existir el bien sin el mal, la pobreza sin la riqueza, la salud sin la enfermedad, la vida sin la muerte, la luz sin la oscuridad... Nada hay que sea inalterable al cambio, porque todo está en un constante movimiento. No existe el cien por cien, todo conlleva un porcentaje de su opuesto.

Como último componente del I Ching, encontramos los "Dictámenes o Sentencias", se podría decir, que su función es atribuir palabras a las imágenes que acompañan cada hexagrama.

El Libro de las Mutaciones fue tanto para Kung Tse (Confucio) como para Lao-Tse una gran fuente de estudio e inspiración. Confucio dedicó gran parte de su vejez a estudiar, analizar y meditar sobre el I Ching. Por tanto, y aunque ambos pensadores posean ideas opuestas ante el modo de actuación frente a la vida, las raíces del taoísmo y el confucionismo están basadas en un mismo libro.

\footnotetext{
${ }^{6}$ http://es.wikipedia.org/wiki/Wu_Xing (21/2/2014 a las 11h).
} 
Posteriormente la idea plasmada en este libro sobre la importancia de los opuestos, llegó a Occidente, donde filósofos o pensadores griegos como Heráclito, se valieron de ella para explicar su visión de la inteligencia y el razonar del hombre, lo que pasaría a denominarse "logos". El logos era una ley universal basada en el devenir de los opuestos. Todo está unido a un cambio constante, nada hay permanente ni en quietud, todo nace y muere.

- En los mismos ríos entramos y no entramos, (pues) somos y no somos (los mismos)"'?.

El agua está en constante movimiento y por tanto nunca nadie puede bañarse en las mismas aguas, aunque el hombre, tampoco es el mismo pues tanto física como psíquicamente ha sufrido una alteración por mínima que sea.

En el Libro de las Mutaciones el agua representa el origen de la vida en la Tierra, porque ella llega a lo terrenal desde el Cielo y cubre una de las necesidades básicas de los seres que allí habitan. El agua es lo Abismal y el lago es lo Sereno. Aunque su apariencia sea blanda y líquida es capaz de superar lo firme y lo sólido, es capaz de apagar el fuego.

Al igual que ocurre con la figura del hombre sabio o santo en el Libro de las Mutaciones, el hombre según Heráclito, es capaz de entender los designios del logos, porque éste nos habla, pero no todas las personas son capaces de entenderlo ni escucharle. Para él, todo parte de un mismo todo, en este caso el logos.

Podríamos seguir describiendo el Libro de las Mutaciones tanto en su faceta filosófica, oracular..., por tiempo ilimitado, pero lo que a nosotros nos interesa más de este libro es su manera de entender el mundo y la función y ubicación que el hombre ocupa en él.

Por tanto, no vamos a realizar un estudio más detallado de cada trigrama, hexagrama o Dictamen, sino que vamos a unificar todas las partes del I Ching e intentar darle una visión global, quedarnos con su esencia, con su espiritualidad.

\footnotetext{
${ }^{7}$ Es.wikipedia.org/wiki/Heráclito (12/2/13 a las 10:15 h).
} 
En el Libro de las Mutaciones se tratan el mundo espiritual e invisible y el mundo terrenal y visible, como opuestos que se complementan para crear la existencia. El mundo espiritual se le define como Ch ien/Lo Creativo, que tiene como imagen el Cielo, en él se da lo invisible, lo espiritual, lo luminoso, lo oscuro, el tiempo, lo masculino, el movimiento, el mundo superior e incorpóreo... Pero el cielo necesitará de K ún/ Lo Receptivo, que tiene como imagen la Tierra, en él se da, lo visible, lo terrenal, lo blando, lo firme, el espacio, la naturaleza, lo femenino, la quietud, el mundo inferior y corpóreo... para la creación de todo lo existente.

Kung Tse escribió al respecto que "grande en verdad es la fuerza original de lo Creativo, todos los seres le deben su comienzo. Y todo el cielo está compenetrado de esta fuerza,8.

Es como si partículas invisibles llenaran el espacio, latentes pero a su vez en constante movimiento en un tiempo concreto, donde todo su ser es espiritual, podemos decir que es el alma, esperando a entrar en contacto con lo terrenal, lo corporal, convirtiéndose la Tierra en madre portadora, engendradora y protectora.

En Lo Creativo por tanto, reside el movimiento y el tiempo, la energía creadora hace que todo se encuentre en perfecto cambio y en un periodo de tiempo idóneo. Por su parte Lo Receptivo, hace mención a lo terrenal, a la naturaleza, a lo femenino. De ahí que sea el encargado de portar y parir la semilla celestial. Las Mutaciones se pueden dar gracias a este constante movimiento producido por la fuerza de los opuestos, que hace que todo cambie y se den de este modo las estaciones, el transcurso de los años, la vida y la muerte, el día y la noche, la abundancia y la necesidad, la luminosidad y la oscuridad, el bien y el mal... Todo es cíclico, no hay nada en el universo que no lo sea, porque todo lo que tiene un principio tiene un final y a su vez un nuevo comienzo. El propio Libro de las Mutaciones termina con el signo "Antes de la Consumación" que hace mención al periodo anterior al orden, cuando todavía reina el caos y el desorden, haciendo un llamamiento al futuro en el que si debe

\footnotetext{
${ }^{8}$ WILHEIM, Richard. I Ching. "El Libro de las Mutaciones". Op. Cit. Pág. 80.
} 
de producirse ese tránsito, por tanto, hace mención a que cualquier final conlleva un nuevo comienzo.

- §3. "Lo Creativo y Lo Receptivo constituyen el verdadero secreto de las Mutaciones. Al presentarse lo Creativo y lo Receptivo en forma cabal, las mutaciones también quedan establecidas entre ellos. Si Lo Creativo y Lo Receptivo fuesen aniquilados, no habría nada en lo cual pudieran verse las mutaciones. Si ya no hubiese mutaciones para ser vistas, también cesarían paulatinamente los efectos de lo Creativo y lo Receptivo".",

Un ejemplo más corpóreo de esto sería la necesidad de todo ser vivo de reproducirse mediante la unión de lo masculino y lo femenino. En el caso del ser humano si el hombre y la mujer, como opuestos, no se complementaran, de su unión no nacería la vida y poco a poco la especie humana desaparecería. Lo mismo le sucedería al universo, si lo Creativo y lo Receptivo desapareciesen todo desaparecería con ellos.

Podríamos decir que mediante esa unión entre Cielo y Tierra, se forma todo el universo, es la transformación de la energía espiritual en terrenal. La energía es la base de todo movimiento. Una vez se ha producido esta unión entre lo Creativo y lo Receptivo, se da el nacimiento de todos los seres. Estos recibirán la energía celestial, pero a su vez también recibirán la energía terrenal, porque se encuentran sobre la Tierra.

El ser humano, en la filosofía oriental, como hemos podido ver forma parte de un Todo, equilibrado por esa complementación entre opuestos que permite crear unas energías de cambio constantes, como son las Mutaciones, y hacen que el orden del universo se mantenga estable de una manera cíclica. Ese orden también marca la vida del ser humano, pues lo Creativo otorga a cada ser su naturaleza y la mantiene en equilibrio con el universo. De ahí, la importancia del Tao, traducido normalmente por camino, todo ser humano debe guiarse por él, debe encontrar su camino y no desviarse durante toda su vida.

Para ello, el ser humano tiene como guía a personas capaces de relacionarse con lo celestial, como son; el rey, el noble o el sabio, que debido a su posición pueden enseñar a aquellas personas que se hayan desviado del

\footnotetext{
${ }^{9}$ WILHEIM, Richard. I Ching. "El Libro de las Mutaciones". Op. Cit. Págs. 410 y 411.
} 
Tao las claves para regresar al buen camino. Un camino de respeto, de lucidez, de razón, de humildad, de bondad, de paz, donde reine el bien. No hay que olvidar que cuando nacemos todos poseemos estas cualidades, pero la elección de nuestros actos conforme avanzamos en la vida va a determinar nuestro destino.

Como hemos podido ver en este mundo de opuestos el bien siempre lleva consigo el mal, y el mal siempre lleva consigo el bien. Por eso, el ser humano debe de aprender a caminar por el buen camino y rechazar y combatir el mal, porque esa es su naturaleza, todo lo demás lo ha mal aprendido.

El Libro de las Mutaciones ha sido creado y estudiado por sabios capaces de relacionarse con el cosmos, por eso plantea un microcosmos capaz de representar mediante los símbolos todas las acciones posibles.

- $\quad \S 2$. "Los santos sabios de tiempos antiguos hicieron el Libro de las Mutaciones de este modo: ellos quisieron escrutar las órdenes de la ley interior y del destino. Establecieron por lo tanto el TAO (sentido) del Cielo y lo denominaron: lo oscuro y lo luminoso. Establecieron el TAO (sentido) de la Tierra y lo denominaron: lo blando y lo firme. Establecieron el TAO (sentido) del hombre y lo denominaron: el amor y la justicia. Juntaron estas tres energías fundamentales y las duplicaron. Por esta causa son siempre seis trazos los que en el Libro de las Mutaciones forman un signo. Los puestos se distribuyen entre oscuros y luminosos; sobre ellos se sitúan, turnándose, trazos blandos y firmes. Por esta razón, el Libro de las Mutaciones tiene seis puestos que dan forma a las figuras lineales".

Para los taoístas alcanzar el Tao, otorgaba a la persona la vida eterna, no refiriéndose a no morir nunca, sino que al tener la capacidad de conocer y comprender las mutaciones, la complementación entre opuestos, el equilibrio universal... su visión del tiempo, tal y como la percibimos los demás, desaparece. En el Tao, el tiempo es presente, desaparece el pasado y el futuro para vivir en una especie de presente continuo.

- "El gran hombre concuerda en su carácter con el Cielo y la Tierra; en su luz con el sol y la luna; en su correcta consecuencia, con las cuatro estaciones; en la dicha y desdicha que origina, con los dioses y espíritus. Donde él se anticipa al Cielo, el Cielo no lo desmiente. Donde él sigue al Cielo, se guía por el tiempo del Cielo. Si aun el Cielo no se le opone, cuánto menos lo harán los hombres, dioses y espíritus." 11

\footnotetext{
${ }^{10}$ WILHEIM, Richard. I Ching. "El Libro de las Mutaciones". Op. Cit. Pág. 351.

${ }^{11}$ WILHEIM, Richard. I Ching. "El Libro de las Mutaciones". Op. Cit. Pág. 474.
} 
El gran hombre o sabio es el ejemplo a seguir, él no ha perdido el contacto con la virtud original otorgada por lo celestial. Sigue manteniendo su bondad e inocencia intactas, por eso, puede relacionarse con el Cielo. Su alma o espiritualidad todavía es pura y no se ha corrompido por las acciones de los hombres, pero puede ver las injusticias y conoce de los pecados y anhelos del hombre, por tanto, puede ayudarle a volver al camino correcto o a permanecer en él si todavía no ha sido corrompido. Son capaces de dirigir los ánimos de los individuos, de conocer el pasado y el futuro, la ventura y desventura y todo ello lo realizan de una manera sutil y sin vanidad, sin buscar un reconocimiento ni aparentar, no son arrogantes ni aduladores, sino personas justas, espirituales y pacíficas. Pero, no se debe olvidar que el mal no se puede llegar a eliminar, solamente hacerlo retroceder, pues el bien necesita y conlleva el mal, es un estado cíclico del que no se puede ni se debe escapar, sino aprender a conocer el universo y poder actuar en concordancia con él.

Como ejemplo de hombre sabio podemos tomar a Lao-Tse, el cual según se cree pudo vivir hasta los 150 años. Hombre humilde, enseñó su visión del mundo a sus seguidores, desde la humildad, la bondad, el respeto hacia el prójimo y hacia uno mismo, la pobreza, la inocencia del que ha culminado su búsqueda y su saber, la paz y la armonía.

Lao-Tse fue uno de los grandes pensadores de la filosofía oriental y por lo tanto, se merece un estudio más detallado en cuanto a su vida y obra. Por tanto, tiene su propio subapartado dentro de este primer capítulo ampliando así los conocimientos sobre él.

Hasta el momento hemos podido ver, cómo la unión del Cielo y la Tierra creaba todo el universo, pero, una vez llegado el momento en que la Madre Tierra pare, y los seres nacientes ocupan el mundo terrenal, es la naturaleza la encargada de alimentarlos y protegerlos. Es una madre protectora que no hace distinción alguna, para ella todos los seres tienen la misma valía. Para llevar a cabo su función necesitará del agua y el fuego, del trueno y el viento, de la montaña y el lago. Estos son los ocho signos del Libro de las Mutaciones.

Esta visión de la tierra como madre engendradora, también podemos encontrarla en la Prehistoria y en la alquimia. En la Prehistoria la cueva era un 
lugar místico de refugio, de protección, de unión entre lo terrenal y lo espiritual. Era en la caverna donde se representan las escenas de caza de una manera gráfica, esperando esa unión con lo espiritual. Era el lugar de protección y de refugio, era como la matriz materna que otorga bienestar y seguridad. Era como refugiarse en la Madre Tierra.

- "El papel ritual de las cavernas, probado en la prehistoria podría interpretarse igualmente como un retorne místico al seno de la <<Madre>>, lo que explicaría tanto las sepulturas en las cavernas como los ritos de iniciación verificados en estos mismos lugares"12.

Para los alquimistas la Madre Tierra guarda en su vientre los minerales como si de embriones se tratara, pues las cavernas y minas de la tierra hacen la función de matriz o de útero. Los minerales nacen, crecen en ella, e incluso se casan (aleaciones). Esta idea podemos encontrarla en el libro de "Herreros $y$ alquimistas" de Mircea Eliade.

- 'Las sustancias minerales participan del carácter sagrado de la Madre Tierra. No tardamos en encontrarnos con la idea de que los minerales<<crecen>> en el vientre de la Tierra, ni más ni menos que si fueran embriones"13.

Por tanto, el ser humano que desde el inicio de los tiempos se ha sentido atraído por esta unión, debe dar gracias a la naturaleza y debe seguir su ejemplo y actuar de una manera tan sabia como ella. La naturaleza no hace distinciones, la naturaleza es tranquila, pacífica, bondadosa y protectora, y ese es el comportamiento al que debe aspirar el hombre. Al fin y al cabo, el hombre no es más que cualquier otro ser alimentado y protegido por ella.

La comprensión y el respeto hacia uno mismo y todo lo que nos rodea, puede ser la clave para alcanzar la libertad, la felicidad y la paz que el ser humano tanto anhela.

Georges Ohsawa en su libro "Filosofía de la medicina de Extremo Oriente" nos da las claves para alcanzar la libertad infinita, la justicia absoluta y el amor eterno, nos otorga el secreto de "la Llave del Reino de los Cielos" en siete pasos:

\footnotetext{
${ }^{12}$ ELIADE, Mircea. "Herreros y alquimistas". Alianza editorial. Madrid, 1999. Pág. 40.

${ }^{13}$ ELIADE, Mircea. "Herreros y alquimistas". Op. Cit. Pág. 10.
} 
1. La ley de Inversión. "Todo lo que comienza, tiene fin".

2. La Ley del Frente y Dorso. "Siempre hay frente y dorso".

3. La Ley de No-Identidad. "Nada es idéntico a otra cosa en este mundo".

4. La Ley del Equilibrio. "Cuanto más grande y más ancho el frente, tanto más grande y más ancho el dorso".

5. El Cambio no es más que la diferenciación o la integración de dos factores antagónicos y complementarios. Yin y Yang. La estabilidad es un equilibrio.

6. Ley de la Polarización. "El infinito absoluto eterno se polariza en Yin y Yang".

7. El Infinito Absoluto Eterno es el Motor Inmóvil de todo lo que cambia, de la transformación incesante de Yin en Yang y de Yang en Yin. ${ }^{14}$

Esta leyes de la lógica universal planteadas por Ohsawa nos hacen comprender que nada tiene un comienzo ni un fin, que no podrían existir el uno sin el otro, que los opuestos se equilibran y se complementan, que las cosas de este mundo son distintas, que cada ser es diferente y que incluso un mismo ser se ve afectado por el tiempo y el espacio, que en muchos casos, las personas por ocultar su verdadera naturaleza y protegerse de esta sociedad, son capaces de cometer los actos más crueles, que el infinito está polarizado en el Yin y el Yang, que ellos están en equilibrio y forman parte de todas las cosas de este mundo y que están en un continuo cambio.

Según la filosofía oriental, las personas que no lleguen a comprender estas leyes y no sean capaces de entender el funcionamiento del universo infinito y nuestro lugar en él, nunca alcanzaran la felicidad, ni serán libres, vivirán atadas a una mentira como es la sociedad actual y olvidarán esa unión energética con todo lo que les rodea. Dejaran de ser parte consciente del Todo, para formar parte de algo ficticio, creado por otras personas con el fin de obtener beneficios.

Por tanto, toda mala acción, padecimiento o destrucción que llevemos a cabo contra la naturaleza, se tornará a su vez en dolor, padecimiento y destrucción para nosotros mismos, porque formamos y somos parte de ella.

\footnotetext{
14 OHSAWA, Georges. "Filosofía de la Medicina en Extremo Oriente. El libro del Juicio Supremo". Traducido por Mauricio Waroquiers. Págs. 98, 99 y 100. Publicaciones Gea. Buenos Aires - Argentina 2005.
} 


\section{Los 5 elementos}

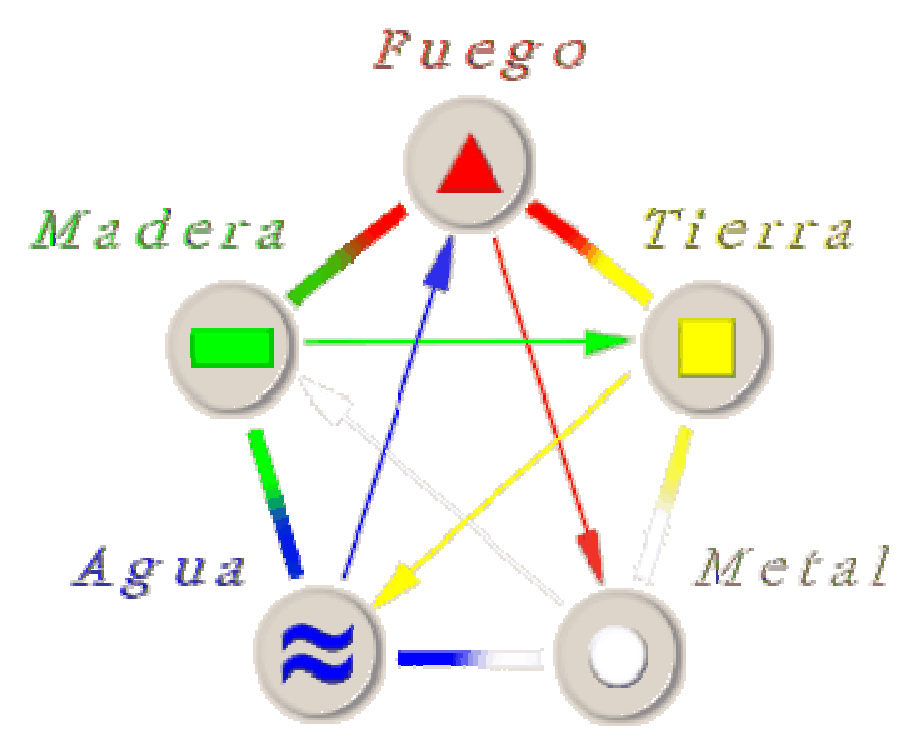

Ilustración 3. Los cinco elementos

forma alargada y color verde

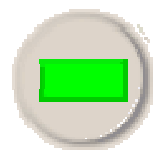

Otras correspondencias

PLANETA: JÚPITER

P. CARDINAL: ESTE

ESTACIÓN: PRIMAVERA

EMOCIÓN: CÓLERA

SENTIDO: VISTA

SABOR: ÁCIDO

ÓRGANO: HIGADO

PLANETA: MARTE

P. CARDINAL: SUR

ESTACIÓN: VERANO

EMOCIÓN: ALEGRÍA

SENTIDO: HABLA

SABOR: AMARGO

ÓRGANO: CORAZÓN 


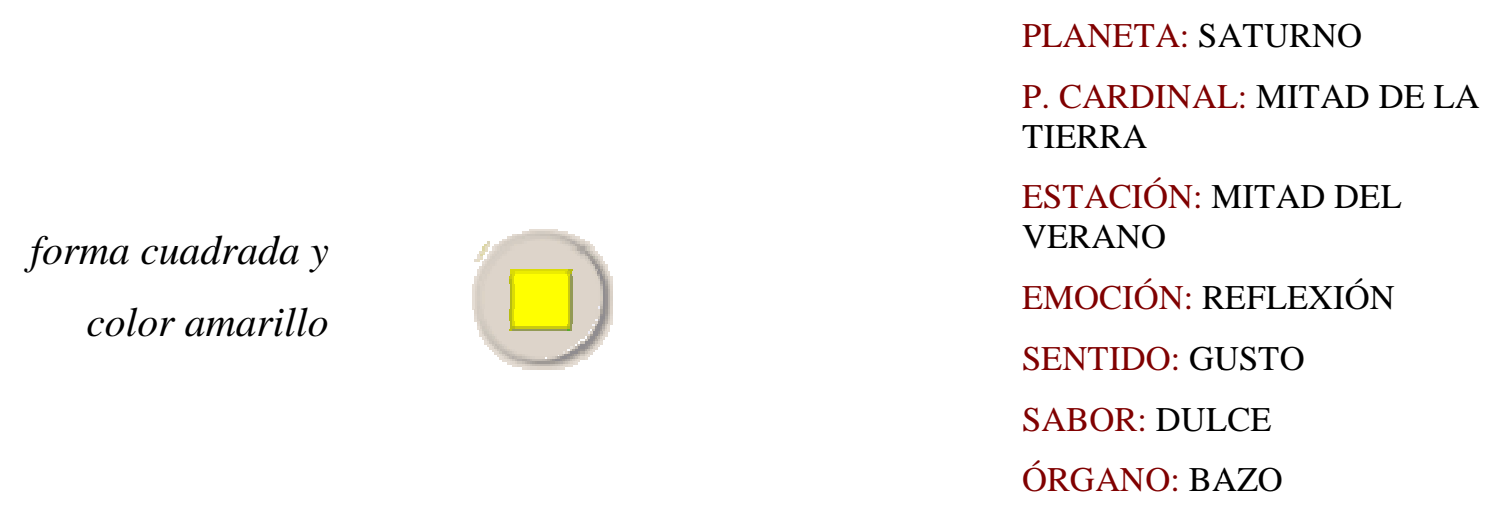

PLANETA: VENUS

P. CARDINAL: OESTE

ESTACIÓN: OTOÑO

forma redonda $y$

EMOCIÓN: TRISTEZA

color blanco

SENTIDO: OLFATO

SABOR: PICANTE

ÓRGANO: PULMÓN

PLANETA: MERCURIO

P. CARDINAL: NORTE

ESTACIÓN: INVIERNO

forma

EMOCIÓN: MIEDO

sinuosa y

SENTIDO: OIDO

color azul

SABOR: SALADO

ÓRGANO: RIÑÓN 
Los elementos se relacionan con los trigramas del I Ching y les prestan sus características y atributos.

Clasificación de los trigramas según los elementos:

\begin{tabular}{|c|c|c|c|c|}
\hline Metal & Madera & Tierra & Agua & Fuego \\
\hline Tui & Sun & Kên & $\mathrm{K}^{\prime} \mathrm{an}$ & $\mathrm{Li}$ \\
\hline$=$ & & $\bar{E}$ & $=$ & 물 \\
\hline Ch'ien & Chên & $\mathrm{K}^{\prime}$ un & & \\
\hline & $\bar{z}$ & 三三 & & \\
\hline
\end{tabular}

\footnotetext{
${ }^{15}$ http://www.saberoculto.es/HorCHINO4.htm [03/06/2015 a las 11h)
} 



\subsection{Lao-Tse y Confucio}


Se podría decir que las tres filosofías orientales más conocidas en Occidente son: el budismo, el taoísmo y el confucionismo. Esto se debe a que todas ellas poseen un gran número de seguidores en Asia. El budismo nace tras la muerte de Gotama (Buda), el taoísmo está basado en las enseñanzas de Lao-Tse y el confucionismo a su vez está basado en las enseñanzas de Kung Tse, más conocido como Confucio.

En el periodo de tiempo donde comienzan a darse estas filosofías tal y como afirma en su tesis Karl Jaspers, "se concentran y coinciden multitud de hechos extraordinarios. En China viven Confucio y Lao-Tse, aparecen todas las direcciones de la filosofía china, meditan Mo ti, Chuang-tse, Lie-tse y otros muchos. En la India surgen los Upanishads, vive Buda, se desarrollan, como en China, todas las posibles tendencias filosóficas, desde el escepticismo al materialismo, la sofística y el nihilismo. En el Irán enseña Zaratrusta la excitante doctrina que presenta el mundo como el combate entre el bien y el mal. En Palestina aparecen los profetas, desde Elías siguiendo por Isaías y Jeremías, hasta el Deuteroisaías. En Grecia encontramos a Homero, los filósofos- Párménides, Heráclito, Platón (...) Todo lo que estos nombres no hacen más que indicar se origina en estos cuantos siglos casi al mismo tiempo en China, en la India, en Occidente, sin que supieran unos de otros. En esta época se constituyen las categorías fundamentales con las cuales todavía pensamos, y se inician las religiones mundiales de las cuales todavía viven los hombres. En todos los sentidos se pone el pie en lo universal". ${ }^{16}$

El periodo de tiempo al que hace mención Karl Jaspers en esta cita es sobre el año 500 antes de Cristo. Es la primera vez que se da un movimiento digamos universal en busca del saber, de conocer de donde procede el hombre y qué función tiene en esta vida, cuál es nuestro destino y el sentido del mundo. Es una búsqueda, podríamos decir, espiritual.

Aunque como hemos visto a lo largo y ancho del planeta se estaba despertando un hambre de conocimiento y reflexión, nosotros nos centraremos en las enseñanzas de un gran maestro de la filosofía oriental como es Lao-Tse. También llamado Lao Zi o Lao Tzu.

\footnotetext{
${ }^{16}$ JASPERS, Karl (Tesis tiempo-eje) mencionado en "Los grandes maestros espirituales de Oriente y Occidente". Ed. Tecnos (grupo Anaya,S.A). Madrid, 2001. Págs. 11 y 12.
} 
Sus enseñanzas están basadas en el Libro de las Mutaciones. El I Ching. Él, al igual que Confucio, vio en este libro el camino a seguir. Lao-Tse basándose en un acercamiento del hombre a su naturaleza; y Confucio, desde una visión más enfocada al hombre en sí y la sociedad.

Estos dos grandes personajes se piensa que fueron contemporáneos en su tiempo, aunque Kung Tse era en ese momento una persona joven y Lao-Tse ya era un anciano. Es muy apreciada en Oriente una conversación que parece ser tuvo lugar entre ellos, donde Kung Tse pidió consejo sobre los ritos al maestro Lao-Tse. Es difícil asegurar si realmente tuvo lugar esta conversación entre ambos maestros, porque no hay datos fehacientes de ello. Pero de lo que si hay constancia es de las diferentes interpretaciones que ambos hacen del I Ching.

Aunque contemporáneos y ambos atraídos por el Libro de las Mutaciones, sus enseñanzas distan bastante una de otra, convirtiéndose LaoTse en el mayor crítico de Confucio. Pero no en todo eran contrarios, pues poseen algunas ideas similares al respecto de situaciones puntuales. Como hemos mencionado anteriormente, las enseñanzas de Lao-Tse se basan más en la naturaleza del hombre y las de Kung Tse en las del hombre como sociedad. 


\section{Lao-Tse:}

\begin{tabular}{|l|}
\hline \multicolumn{1}{|c|}{ XXIII } \\
Conocer a los demás es sabiduría, \\
conocerse a sí mismo es iluminación. \\
Vencer a los demás es tener fuerza, \\
vencerse a sí mismo es ser poderoso. \\
Esforzarse en avanzar es tener voluntad; \\
Saber contentarse es ser rico. \\
No alejarse de su sitio es durabilidad; \\
morir sin perecer es longevidad.
\end{tabular}

XLVIII
Quien se dedica al estudio crece día a día;
quien se dedica al curso mengua día a día.
Mengua y mengua
basta alcanzar la inacción.
No actuando, nada hay que no haga.
Se obtienen cuanto hay bajo el cielo
estando siempre desocupado.
En cuanto uno tiene ocupaciones,
no es apto para obtener todo bajo el cielo.

LXVIII
El mejor adalid no es belicoso;
el mejor guerrero no es impetuoso;
el mejor vencedor de enemigos es el que no se enfrenta;
el mejor empleador de hombres es el que se rebaja ante ellos.
Es lo que se dice virtud del no rivalizar,
es lo que se dice poder del empleo de hombres,
es lo que se dice cumbre de la conformidad con el cielo.

\footnotetext{
${ }^{17}$ Lao Zi. "Libro del curso y de la virtud. Dao de Jing". Prologo François Jullien. Edición y traducción del chino: Anne-Heléne Suárez. Ediciones Siruela. Madrid, 1998. Págs. 95, 125 y 165.
} 


\section{Confucio:}

\section{IV}

$\ll<$ A los quince años mi voluntad se aplicaba al estudio.

$>$ A los treinta estaba firme.

>>A los cuarenta no tenía dudas.

>>A los cincuenta conocía el Mandato del Cielo.

>> A los sesenta podía escuchar las verdades sin dificultad.

>> A los setenta podía seguir lo que mi corazón deseara sin hacer el mal>>.

\section{XXV}

< El hombre superior es fácil de servir y difícil de complacer. Si para complacerle no se utiliza un buen camino, no quedará complacido. Él, por su parte, dará a cada persona la responsabilidad para la que cada uno esté preparado. El hombre vulgar, en cambio, es difícil de servir y fácil de complacer. Aunque no se use del buen camino para complacerle, quedará satisfecho, mientras que pretenderá que cualquier persona cargue con cualquier responsabilidad $>$.

\section{IV}

<<Cuando el estado está bien gobernado, se puede actuar y hablar con osadía, cuando está mal gobernado, se puede actuar con osadía, pero hay que hablar con prudencia>>.

\footnotetext{
${ }^{18}$ Confucio. "Los cuatros libros". ANALECTAS. Libro II. WEI ZHENG. Ediciones R.B.A. Barcelona, 2006. Pág. 55.

${ }^{19}$ Confucio. "Los cuatros libros". Libro XIII. ZI LU. Op. Cit. Pág. 123.

${ }^{20}$ Confucio. "Los cuatro libros". Libro XIV. XIAN WEN. Op.Cit. Pág. 125.
} 
En estos ejemplos podemos ver claramente cómo Lao-Tse basa su vida en el no actuar (pero actuando), en el dejar fluir, en el estudio de uno mismo mediante meditación o técnicas que nos acerquen a nuestra naturaleza y nos enseñen el camino. Para ello, deberemos desaprender lo ya aprendido porque solo liberándonos de nuestras creencias, nuestra sabiduría... aprendida en el mundo físico alcanzaremos el Tao.

Para Confucio por el contrario, la sabiduría, la inteligencia y la enseñanza tienen valores completamente distintos. Él mismo busca el reconocimiento social y alcanzar una posición digna por medio de su sabiduría. Piensa que la inteligencia mejora al hombre y que el poseedor de ella, debe de hacerse notar, poseer grandes cargos y ser respetado. Lao-Tse busca todo lo contrario, es un sabio oculto, él no espera ni cree merecer ningún tipo de respeto especial, ni ningún cargo público, sólo desea vivir conforme al Tao, eliminando lo aprendido, respetando al prójimo, siendo justo, espontáneo, paciente, calmado, sin dejarse llevar por los bienes ni deseos materiales ni carnales, no actuando, sin dejarse notar como ocurre en el mandato de los grandes reyes pero sin aislarse del mundo, no es un ermitaño, no quiere vivir oculto, piensa que uno puede alcanzar el Tao en cualquier parte porque es algo intrínseco a uno mismo, depende de tus pensamientos, de tus meditaciones, de tus acciones...

Los occidentales históricamente se han sentido más unidos a las creencias de Confucio que a las de Lao-Tse. En el siglo XIV muchos ejemplares del taoísmo fueron quemados por estar relacionados con la brujería y las artes oscuras. Pero el taoísmo pervivió a esta persecución debido a que sus enseñanzas no solían ser escritas sino orales, con lo cual iban pasando de generación en generación.

Esta persecución y quema de ejemplares se debía a que la alquimia china siempre ha estado muy relacionada con el taoísmo, pues la búsqueda del elixir de la inmortalidad se basaba en el estudio de los Cinco Elementos, del I Ching, del Yin y el Yang, de la medicina china, de algunas artes marciales...

La inmortalidad no se puede alcanzar si no existe la unidad con el Tao, pero una vez alcanzada esta, el ser entra a formar parte de lo inicial, del origen 
de todo y por tanto, el concepto de vida y muerte desaparece. Ya no existe el tiempo tal y como lo conocemos, el pasado, el presente y el futuro, se unen y conviven en un único momento presente.

Lao-Tse se cree que vivió sobre ochenta años, aunque existen documentos donde se indica que no fue así y que llegó a vivir cerca de doscientos años por haber alcanzado esa inmortalidad tan deseada por los taoístas y los alquimistas orientales.

En el siglo XVII comenzaron a realizarse los primeros estudios sobre la cultura china, que se basaban en el estudio del canon confuciano y el budismo, no en el taoísmo. Con el paso del tiempo, el budismo también resultó ser una amenaza ante los ojos del cristianismo y sólo el canon confuciano fue aceptado por ellos. Tuvieron que pasar varios siglos hasta que se realizaron las primeras traducciones y estudios sobre el Dao de Jing.

Lao-Tse nació en el reino de Chu, aunque no hay constancia de la fecha exacta. Se cree que fue en el siglo VI a.C porque de no ser así la famosa conversación entre Confucio y él, no sería posible. El maestro no vivió aislado del mundo sin tener contacto con la sociedad del momento, sino que participó de la vida como el resto de sus contemporáneos pero siempre conforme al origen del Tao. Era una persona alegre, paciente, pacífica, de poco hablar y mucho escuchar, y nunca tuvo conflictos con nadie.

Falleció siendo muy anciano, tanto que algunas personas afirman que vivió entre ciento cincuenta y dos cientos años. Podemos decir que, Lao-Tse obtuvo esa "inmortalidad" tan preciada y buscada por los taoístas y que sólo los grandes sabios que viven conforme al Tao y llegan a integrarse con él, son capaces de alcanzar. Trabajó como historiógrafo (archivero de la corte de la realeza Zhou) en su reino natal hasta que cansado de ver cómo las costumbres iban desapareciendo, cada vez había más decadencia y lucha, pues el maestro vivió el periodo denominado Señoríos Guerreros, decidió a una edad ya avanzada dejarlo todo y marcharse hacia el occidente. Antes de irse dejó al guardián que había en la frontera un tratado con sus enseñanzas, unos cinco mil caracteres. El escrito estaba dividido en dos partes, en la primera Lao-Tse hacía mención al dao (curso), y en la segunda al de (virtud). Este escrito se 
convertiría en uno de los libros más importantes de la filosofía oriental, el Dao de Jing (en algunas obras el Dao viene escrito como Tao, el de aparece como te y Jing como King, pero su significado es el mismo o equivalente).

Hay una leyenda procedente de fuentes taoístas recogida por el sinólogo francés, L. Laloy que trata sobre la vida de Lao-Tse y el Tao Te Ching. En ella, Lao Tzu aparece en este mundo por nacimiento virginal. Su madre le dio a luz bajo la sombra de un ciruelo, después de haber tragado un huevo en forma de perla. El embarazo duró setenta y dos años. Lao nació como niño viejo, con cabello cano y rostro arrugado, y como tenía orejas más grandes de lo normal se le dio el nombre de Li-Tan (orejas largas), el que fue sustituido después por sus seguidores con el de Lao Tzu (el viejo sabio).

La leyenda indica luego varios viajes a distintos países de Oriente y su vuelta a la China donde ejerció un cargo de funcionario en el estado de Chu. Pero terminó bruscamente su carrera, cuando subió sobre un carro conducido por un buey azul, para alcanzar las fronteras del reino. Allí encontró a Yin-hi, oficial gobernador del paso de Han-ku, hombre virtuoso, que escondía su sabiduría. Yin-hi, que había tenido una premonición de que iba a encontrarse con un gran sabio, después de haber conversado con Lao Tzu, le suplicó que pusiera por escrito su enseñanza. ${ }^{21}$

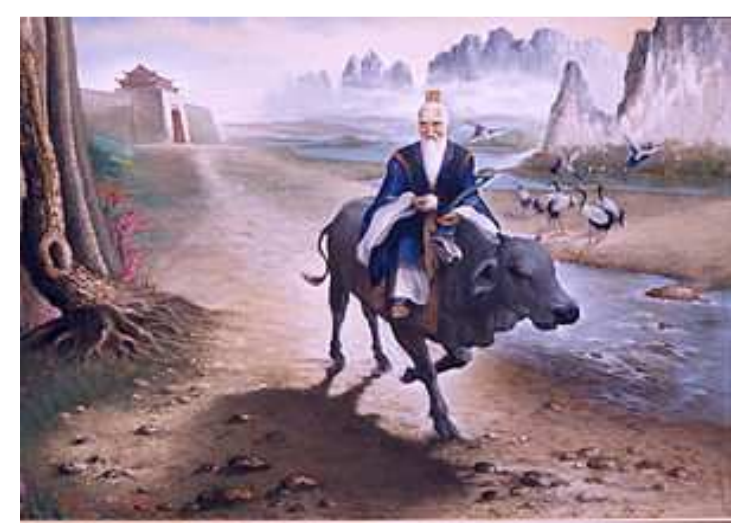

Ilustración 4. Lao-Tse

\footnotetext{
${ }^{21}$ LAO TZU. “Tao Te Ching”. Ed. Azul. Barcelona, 1999. Pág. 9. Ed. Azul. L. Laloy, nombrado en Tao Te Ching.
} 
En Oriente las orejas grandes son un símbolo de sabiduría, por eso en esta leyenda Lao Tzu es poseedor de ellas. También el hecho de que naciera anciano y con el pelo cano le otorga el saber de aquellos que ya han vivido y conocido las alegrías y las penurias de la existencia.

Como todo libro antiguo, ha sufrido alteraciones debido a que en cada periodo histórico, cultural o religioso, se ha ido modificando para estar en concordancia con la época, el lugar o la moda que existía en ese momento. De ahí la cantidad de versiones existentes del mismo libro.

En él, de una manera muy meditada pretende Lao-Tse que entendamos cual es el sentido del $<<D a o>>$ y del $<<D e>>$. Nos habla del camino que el hombre debe seguir para estar en unión con la naturaleza y el universo. Toda la filosofía de Lao-Tse se basa en el Dao.

El Dao o Tao, significa camino, aunque Lao-Tse prefiere llamarlo curso, y De o te, significa virtud.

- "El Tao es el mundo y todas las cosas, así como el origen y la meta del pensador. El contenido de esta filosofía consiste, en primer lugar, en qué es el Tao; en segundo lugar, en cómo lo que es, es a partir de él y para él; en tercer lugar, en cómo vive el hombre en el Tao, y en cómo puede perderlo y recuperarlo como individuo o en la situación del gobierno del Estado,22.

${ }^{22}$ JASPERS, Karl. "Los grandes maestros espirituales de Oriente y Occidente”. Op. Cit. Pág. 75. 


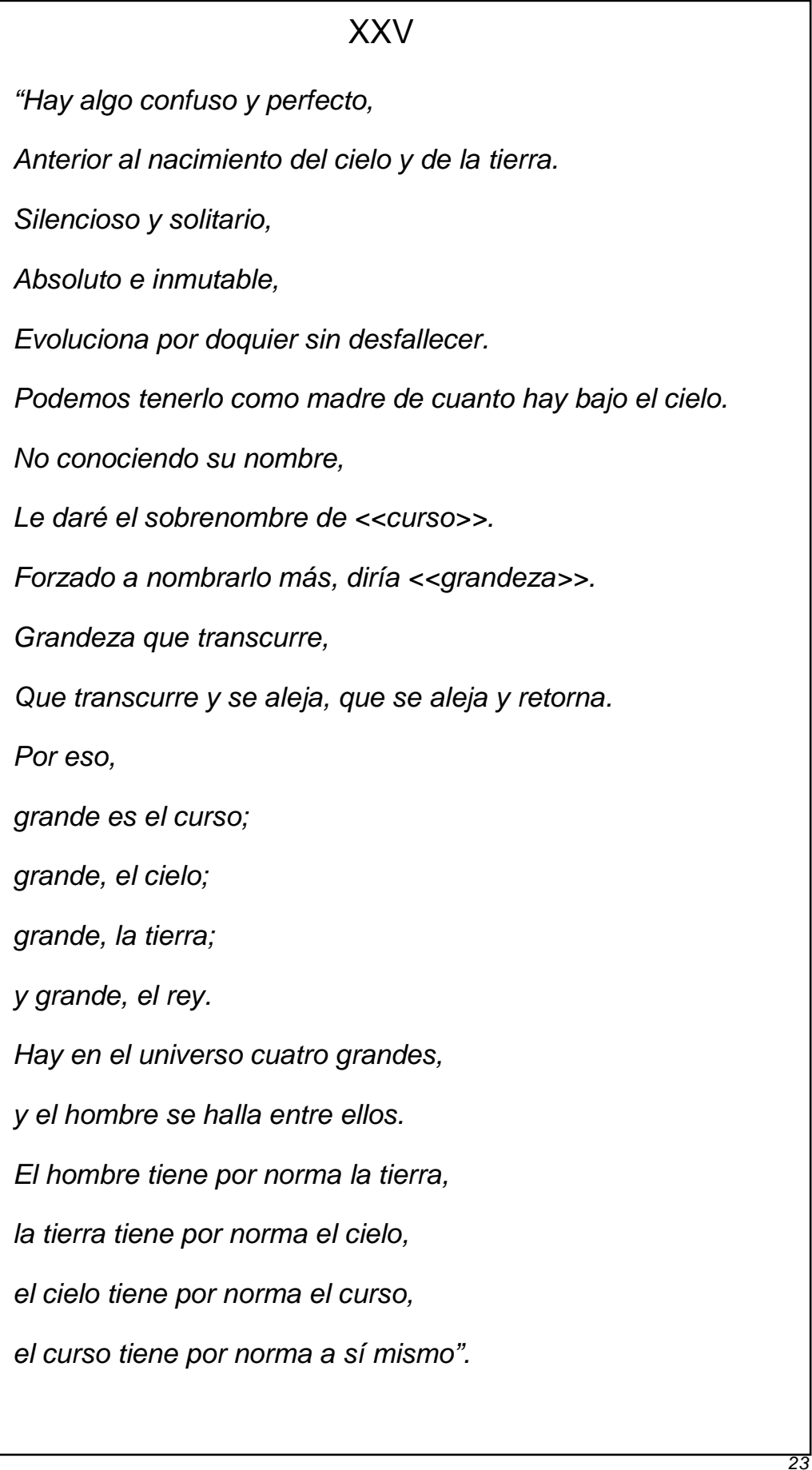

${ }^{23}$ LAO ZI. "Libro del curso y de la virtud. Dao de Jing”. Op. Cit. Pág. 79. 
El Tao es para el maestro el fondo del ser, va más allá de la ordenación del universo, del comienzo de todas las cosas, es el principio de todo y a la vez el fin. Se encuentra presente en todo lo terrenal y lo celestial, porque ya existía antes del Cielo y la Tierra, antes de los dioses. Por eso, Lao-Tse dice que no tiene nombre, que no se puede dividir, no se puede clasificar, es innombrable, indivisible, inmutable, inagotable, imperceptible, lo absoluto, no envejece... Da origen al Cielo y la Tierra y la unión de éstos a su vez da vida a todos los seres vivos. Convirtiéndose el Cielo en el elemento masculino que fecunda al elemento femenino en este caso, la Tierra. Una vez engendrada, nacerán los diez mil seres.

- "Aunque es imperceptible, podemos experimentarlo en todos los entes como el ser auténtico. Está presente en todo, es aquello en virtud de lo cual todo, sea lo que sea, recibe su ser. Los signos de su presencia en el mundo son:

a) Se presenta como no ser.

b) Actúa como si no actuara.

c) El Tao es, en todo ser uno, el origen de lo Uno.

d) Todo ser recibe su existencia a través del Tao.

e) El Tao se encuentra más allá del bien y del mal y, sin embargo, es infinitamente dadivoso". ${ }^{24}$

El hombre debe vivir en el Tao y para ello debe actuar como él. No debe dejarse llevar por los bienes materiales, por los deseos, por los sentimientos, debe de ser cabal, sencillo, débil, tierno, espontáneo, humilde, blando, aprender a actuar no actuando, a ser no siendo, a dejar que todo fluya en el universo. No hay que olvidar que el daño que hagamos a otros o a la propia naturaleza nos lo estamos haciendo a nosotros mismos pues todos somos Uno.

Las cualidades nombradas anteriormente se asemejan a las del elemento agua, este es blando, fluido, adaptable... pero es capaz de vencer a lo rígido, lo fuerte, lo seco, lo duro... porque las cualidades primeras nos acercan a la vida y las últimas cualidades nos acercan a la muerte. Si una persona realiza acciones que ofenden a los demás y no vive en paz con ellos, ni consigo mismo, se creará enemigos y no podrá vivir de manera tranquila. Este comportamiento y aptitud le llevará seguramente a morir a temprana edad.

\footnotetext{
${ }^{24}$ JASPERS, Karl. "Los grandes maestros espirituales de Oriente y Occidente". Op.Cit. Págs. 78 y 79.
} 


LXXVI
El hombre es al nacer, blando y débil;
al morir, queda duro y rígido.
Las plantas y los árboles, al nacer, son tiernos y frágiles;
al morir, quedan secos y enjutos.
Por eso,
lo duro y rígido va camino de la muerte;
lo blando y débil va camino de la vida.
Así,
El arma rígida es destruida,
el árbol rígido se quiebra.
Lo duro y lo rígido es inferior;
lo tierno y débil es superior.

El ser humano es poseedor de dos tipos de almas y debe mantenerlas en unidad y eso sólo es posible si se vive conforme al curso. Una de ellas, es celeste y reside en el espacio y volverá a él una vez el ser humano perezca. La otra se introduce en el ser humano en el momento de su concepción y permanecerá en él, una vez fallecido. Ambas se complementan.

No hay que olvidar que somos parte de un Todo y somos una especie de energía, por denominarla de alguna manera, que está presente en el universo y que llegado el momento se materializa por medio de la unión del cielo y la tierra, pero una vez fallecidos esa energía regresa a ese infinito

El ser humano debe ser débil y tierno porque estas características siempre superan a lo fuerte y lo duro. Como ejemplo de ello encontramos el junco. Éste es capaz de doblarse con el viento y así, permanecer siempre en

${ }^{25}$ LAO ZI. “Libro del curso y de la virtud Dao De Jing “. Op. Cit. Pág. 181. 
pie. Si el tronco es muy rígido pierde esta capacidad de adaptación y si sufre graves inclemencias del tiempo puede llegar a quebrarse y morir.

Los niños al nacer son inocentes, blandos, sencillos, espontáneos y esa es la esencia que no se debe perder, así es el sabio. Es el momento de la vida donde más conectados estamos con el Tao y es esa conexión la que debemos de mantener o tratar de recuperar conforme vayamos creciendo porque al alejarnos del Tao nuestro carácter y con él nuestro cuerpo se va secando, se vuelve rígido y nos acerca a la muerte.

Otro ejemplo de esto, puede ser el agua. Es uno de los elementos más fuertes que existen debido a su naturaleza blanda porque puede engendrar la vida y a su vez puede apagar el fuego, destruir y arrasarlo todo a su paso.

LXXVIII
No hay bajo el cielo cosa más blanda y débil que el agua.
Sin embargo, en su embate contra lo rígido y duro,
nada lo supera,
es irremplazable.
El que lo débil vence a lo duro
y lo blando vence a lo firme
es cosa que, bajo el cielo, nadie ignora,
más nadie aplica.
(...)

Por tanto, lo débil, lo blando y lo tierno nos acercan a la vida y lo duro, lo rígido y lo fuerte nos acercan a la muerte.

El ser humano también debe de actuar no actuando, debe dejar que el universo fluya sin interrumpirlo. No se trata de no hacer nada, sino de actuar de modo que tu actuación no afecte al Tao.

\footnotetext{
${ }^{26}$ LAO ZI "Libro del curso y de la virtud. Dao de Jing”. Op. Cit. Pág. 185.
} 
Pensamos erróneamente que todo lo que sucede en el mundo se debe y gira alrededor de nuestro entorno, que magnificamos todo lo que tocamos y que nada se llevaría a cabo sin nuestro aporte, pues somos el animal racional de la naturaleza y por tanto, el más sabio y conocedor del mundo, pero no es así. El resto de seres vivos pueden no tener un cerebro tan desarrollado y complejo como el nuestro pero nos demuestran con sus acciones que están más unidos a la naturaleza que nosotros, que su instinto les guía en su supervivencia, que cuidan el medio en el que viven y son capaces de percibir el peligro mucho antes de que ocurra y eso es porque no han perdido la conexión con el universo.

Cuando Lao-Tse hace mención a dejar fluir, se refiere tanto a los acontecimientos que puedan surgirnos a lo largo de nuestra vida, como a los cambios cíclicos que experimenta la naturaleza. Es decir, el día da paso a la noche, las estaciones se repiten, las personas nacen y mueren, la luz da paso a la oscuridad, la sequía da paso a una época lluviosa... Todo ello sucede sin que nada ni nadie intervenga y por mucho que intentemos evitarlo no podemos alterar el curso natural de las cosas.

En nuestra vida cotidiana, también nos irán surgiendo una serie de dudas, problemas, enfermedades... pero como el universo se rige por el cambio y el movimiento dado por la complementación de los opuestos, no hay más que aceptar las cosas tal y como vienen porque somos conscientes que todo tiene un sentido y llegado a un punto, lo que era negro se tornará blanco, lo que era oscuridad se tornará lumínico, lo que era enfermedad se tornará en salud, lo que era tristeza se tornará alegría, todo es cuestión de no actuar y tener paciencia, el tiempo lo cambia todo. No hay que enfrentarse a nadie, no hay que contestar a las ofensas sino es con buenas palabras, hay que tratar a todos con respeto sin que nos dañen sus opiniones o sus actos, hay que seguir el camino del Tao y dejarse llevar por él. Hay que ser agua frente a lo duro y seco.

Todas estas actitudes y comportamientos nombrados hasta el momento, son los que debe de poseer un buen gobernante. Además, debe actuar sin que el pueblo sienta su presencia, porque así el pueblo se siente libre y actúa como 
debe. Si un gobernante impone al pueblo lo que debe hacer, éste se revela y comienzan los conflictos y por tanto, ha errado como gobernante.

LXXII
Cuando el pueblo no teme a la majestad,
mayor majestad advierte.
No lo hacines en sus moradas,
no lo canses en su vivir.
Sólo no cansándolo
no se cansará.
Por eso, el santo
se aprecia a sí mismo pero no se exhibe;
se aprecia a sí mismo, pero no se enaltece;
pues rechaza esto y elige aquello.

La sabiduría y la inteligencia no son aspectos que Lao-Tse valore de manera especial, cree que es más fácil gobernar un pueblo que vive en la ignorancia porque ellos alcanzarán antes su bienestar y no surgirán envidias ni males promovidos por el hombre, pues somos buenos, justos y sabios por naturaleza. Por tanto, todo lo aprendido nos aleja de esa naturaleza primordial e inicial con la que nacemos. La justicia no hace más que alimentar el pecado y eliminar la piedad intrínseca del ser humano. La justicia, la sabiduría, la inteligencia, la industria, todo lo artificial, nos aleja del Tao y por tanto, debemos evitarlo.

- "Cuando surgen la inteligencia y el saber aparece el gran artificio". ${ }^{28}$

Hay que dejar de lado las necesidades creadas por la civilización y buscar la simplicidad y la naturaleza. Olvidarse del exceso de cultura y dejar

\footnotetext{
${ }^{27}$ LAO ZI. "Libro del curso y de la virtud. Dao de Jing". Op. Cit. Pág. 173.

${ }^{28}$ LAO ZI "Libro del curso y de la virtud. Dao de Jing". Op. Cit. Pág. 65.
} 
que todo lleve su curso conforme a las leyes universales. Todo saber aprendido nos aleja del Curso, para acercarnos a él debemos olvidar lo ya aprendido para no acercarnos con ideas preconcebidas, actuaciones no innatas... el Curso se alcanza con el no actuar, con la espontaneidad, con la no intencionalidad...

Pero como he mencionado anteriormente, la doctrina taoísta, no nace con Lao-Tse. Su origen podemos encontrarlo en la antigua cultura china. Se desarrolló en el valle del río Amarillo donde gobernaba el Emperador Amarillo (Huang di). Las tribus que vivían en esa zona estaban muy unidas al chamanismo y a los oráculos, practicaban técnicas adivinatorias.

Los campesinos miraban al cielo y buscaban respuestas a los cambios climáticos, las precipitaciones, el nacimiento de las diferentes especies, comportamientos humanos, etc. Para ello, elaboraron un calendario para que tanto los cambios estacionales como la agricultura y las relaciones sociales se hallaran en armonía en los distintos periodos de cambio. Con estos estudios cosmológicos, llegaron a la conclusión que todo venía dado por un movimiento cíclico y que era la ley de los opuestos el motor que hacía girar el mundo. Es decir, al día siempre le sigue la noche, a un periodo de bajas temperaturas siempre le sigue uno de temperatura elevadas, a la vida le sigue la muerte, a la luz la oscuridad...y se dieron cuenta que no existía nada que poseyera el cien por cien en su totalidad. Es decir que, el bien siempre conlleva el mal, la salud siempre conlleva la enfermedad, la alegría siempre conlleva la tristeza, la riqueza siempre conlleva la pobreza, la paz siempre conlleva la guerra... y a la inversa. Esta complementación entre opuestos es el motor del universo. 
II

Todos bajo el cielo reconocen la belleza de lo bello, luego la fealdad.

Todos reconocen la bondad de lo bueno, luego la maldad.

Por eso,

el ser y la nada se generan uno a otro,

lo difícil y lo fácil se complementan uno con otro,

lo largo y lo corto se forman uno de otro,

lo alto y lo bajo se vierten uno en otro,

el sonido y el tono se armonizan uno con otro,

el antes y el después se siguen uno a otro.

(...)

Todas estas enseñanzas están plasmadas como hemos podido ver, en el que sería uno de los libros más relevantes e importantes de la cultura china, el I Ching o Libro de las Mutaciones. Posteriormente y con una serie de añadidos, este libro se convirtió en uno de los oráculos más utilizado en Oriente, y con el paso de los siglos también en Occidente.

Se podría decir que, este libro es el padre de las dos doctrinas más importantes de Oriente, el taoísmo y el confucionismo. No hay que olvidar que el taoísmo tal y como lo conocemos actualmente es una religión que, aunque basada en las antiguas enseñanzas del maestro, ha visto alterada su visión por el paso de los años, las guerras y la sociedad. Actualmente la figura de LaoTse es venerada, conocida y admirada en todo el mundo, mientras el maestro solo quería permanecer "oculto".

${ }^{29}$ LAO ZI "Libro del curso y de la virtud. Dao de Jing”. Op. Cit. Pág. 33. 
Lo mismo sucede con el budismo, el confucianismo y muchas otras doctrinas que con el paso de los años se han convertido en religiones establecidas.

Pero como hemos mencionado anteriormente, Lao- Tse no sólo basó sus enseñanzas en la creación del Tao Te King. También existió una enseñanza oral entre el maestro y sus discípulos, gracias a ella el taoísmo fue capaz de sobrevivir durante los siglos en los que estaba perseguido. Sus discípulos se encargaron de seguir difundiendo las enseñanzas del maestro una vez desaparecido éste. Estas enseñanzas posteriormente quedarían reflejadas en el libro Hua Hu Ching.

Otro gran maestro de la filosofía oriental mencionado anteriormente fue Kung Tse, más conocido como Confucio.

Confucio nació y murió en el pequeño estado de Lu en China. Se piensa que en el periodo de 551 a.C. al 479 a.C. Vivió bajo el mandato de la dinastía Zhou.

Aunque su padre murió cuando él era tan solo un niño, recibió una buena educación y llego a convertirse en Ministro de Justicia en el estado de Lu. Por desacuerdos con la manera de gobernar del príncipe renunció a su cargo y decidió enseñar su sabiduría de una manera regular a los alumnos que quisieron seguir sus enseñanzas. Podemos decir que, fue el primer maestro en crear una escuela. Aunque dista bastante del concepto y la visión que poseemos de la educación y la escuela actual. Era un aprendizaje oral basado en teoría y práctica donde el maestro por medio de una serie de preguntas basadas en situaciones ficticias o reales formuladas a sus alumnos, le permitía conocer por las respuestas de estos, cómo obrarían en determinadas situaciones y enseñarles cómo deberían hacerlo mediante frases o acciones, que les incitaran a razonar sobre ellas y así, obtener ellos mismos las conclusiones deseadas.

La educación y la música son las grandes pasiones de Confucio. La música es para él la prolongación de quien la produce, se puede llegar a percibir los sentimientos y emociones de una persona al escucharla tocar una 
melodía. La música nos acerca al mundo animal, al mundo vegetal e incluso crea vínculos entre los hombres.

Confucio basaba sus enseñanzas en el hombre como individuo dentro de una sociedad, de una cultura y el orden que ésta debe de ocupar dentro del universo al que pertenece, no concibe el hombre como individuo aislado. De ahí, que Lao-Tse se convirtiera en su mayor crítico.

La tolerancia, la bondad, la benevolencia, el amor al prójimo (mayor grado de moralidad) y el respeto a los mayores y antepasados se convirtieron en las principales virtudes de su enseñanza y los ritos también entraron a formar parte de ella. Todo con el fin de enseñar y potenciar la naturaleza humana. Una naturaleza que se crea en el Cielo como parte de un Todo y que con sus actos no debe esperar ninguna recompensa que no sea la satisfacción y la tranquilidad que da el estar en armonía con el Cielo.

El Cielo es, el lugar donde se crea todo y de él provienen las leyes universales que el hombre debe seguir a lo largo de su vida. El soberano tiene una relación directa con las leyes del Cielo y por eso, es capaz de guiar por el buen camino a su pueblo y crear una sociedad correcta y en paz con el universo. Podríamos decir, que el Tao en este caso, es el camino a seguir para estar en concordancia con el Cielo y poder llevar así, una vida plena, tranquila y feliz; aunque no desde una visión individual, sino social. El hombre nunca llegará a alcanzar la felicidad, el bienestar, la paz... fuera de una sociedad.

Del elemento creador dice Confucio:

- $\quad<$ <rande es, en verdad, la sublimidad del elemento creador, al que deben todas las cosas su comienzo y que penetra todo el cielo. Las nubes corren y la lluvia hace germinar, y todas las criaturas son arrastradas dentro de su forma.

El camino del elemento creador obra por el cambio y la transformación; cada cosa recibe su verdadera naturaleza $y$ destino $y$ viene a estar de acuerdo permanentemente con la gran armonía: esto es lo estimulante y lo perseverante>>.

(...) La creación se realiza, por decirlo así, en dos actos. El primero es el conjunto de todos los seres, el cosmos, que, como un todo, debe el comienzo al elemento creador, al verse penetrado todo el cielo; el mundo invisible de la fuerza, por los estímulos creadores. El segundo acto es el tránsito del ser en general al ser de este o aquel modo. ${ }^{30}$

\footnotetext{
${ }^{30}$ WILHELM, Richard. “Confucio”. Alianza editorial. Madrid, 1986. Págs. 231 y 232.
} 
Confucio entiende el comienzo de la vida con la unión de Cielo y Tierra, tal y como hemos podido estudiar en el / Ching, de esa unión nacerían todos los seres, incluido el ser humano, y debemos seguir ligados a ella en cuanto debemos obrar correctamente, respetar al prójimo, ser benevolentes, tener amor filial... y no desviarnos del camino correcto. Sus enseñanzas se basan en enseñar a ser y a actuar como hombres en armonía con el Cielo. Un Cielo y una Tierra que nos otorgan todo lo necesario para sobrevivir y poder nutrirnos tanto a nivel físico como espiritual. No existe el concepto de antropocentrismo, es más bien, un concepto de igualdad y de hermandad con relación al resto de seres vivos.

No está de acuerdo con Lao-Tse en la visión de que la ignorancia es buena para las personas, porque evita conflictos mayores. Piensa que el estudio y el saber es la clave para llevar una vida correcta. El hombre posee en su interior la fuerza cósmica que le ayudará a seguir en el camino correcto, pero para ello, debe de guiarse tanto por las enseñanzas como por la práctica de éstas. Por eso Confucio enseña a sus discípulos con su ejemplo, una vida basada conforme a las leyes del Cielo. Una vida en la que el maestro no se aisló del mundo, sino que trabajó como Ministro de Trabajos Públicos y posteriormente, como Ministro de Justicia. Una vida basada en el respeto, el estudio, la tradición, la música...

Confucio dedicó sus últimos años de vida a estudiar y ampliar el / Ching. El Libro de las Mutaciones, donde como hemos podido comprobar, el devenir de los opuestos es la energía que mueve el mundo y lo hace de una manera cíclica. 


\subsection{Panteismo. Spinoza}


Esta idea de la existencia de un Todo, no es algo puntual en Oriente. Filósofos posteriores como Heráclito o el neerlandes, Baruch Spinoza en el siglo XVII basan sus ideas en un Dios creador que dista mucho de la imagen o concepto que tenemos de él actualmente. Su Dios es más como una unidad que lo envuelve y crea todo, es el sumo y todo bien. Nada existe y se concibe sin él. Es una visión monista, que nace de la unificación de universo, naturaleza y Dios. Por eso, aunque sus filosofías parten de la razón, son clasificados por algunas personas como ateas, al eliminar o no creer en Dios como un ser aislado o superior y así, negarle su divinidad.

Tanto Spinoza como Heráclito, junto con otros filósofos como Bruno o Plotino, fueron llamados racionalistas y clasificados en una doctrina filosófica denominada Panteísmo. A Spinoza se le considera uno de los miembros más destacados de esta creencia.

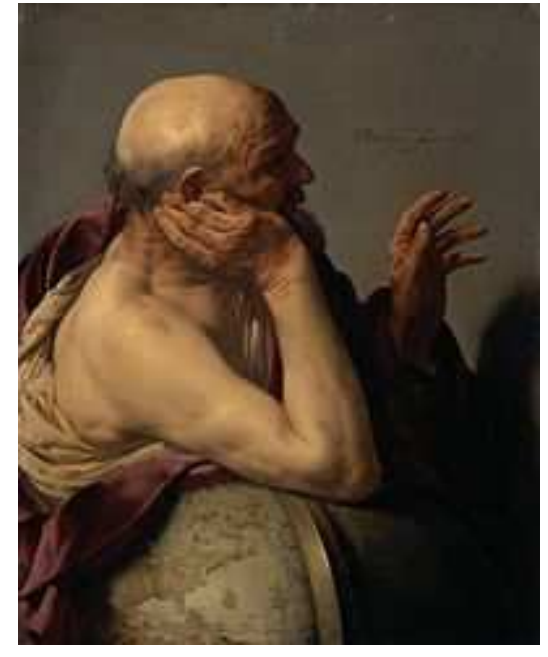

Ilustración 5. Heráclito llorando, por Hendrick Ter Brugghen (1628)

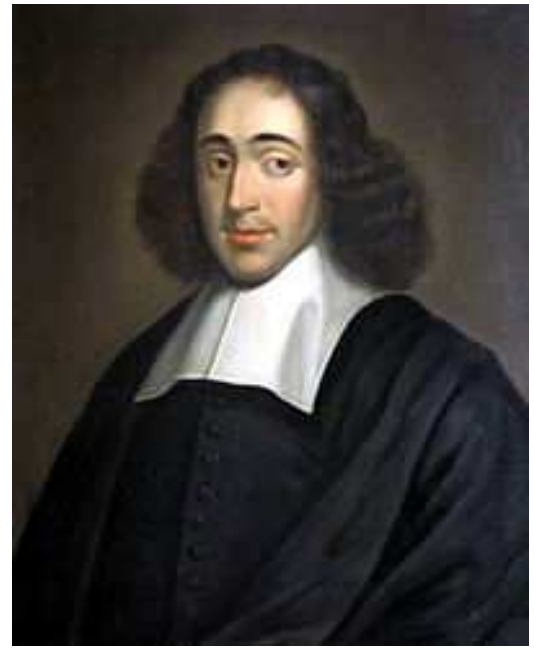

Ilustración 6. Retrato de Baruch de Spinoza cerca de 1665 
Si analizamos la palabra panteísmo podemos comprobar que “(...) La palabra está compuesta del término griego mãv (pan), que significa todo, y $\theta \varepsilon o ́ s$ (theos), que significa Dios; así se forma una frase que afirma: todo es Dios y Dios es todo". ${ }^{31}$

El panteísmo está basado en la idea de unificación del universo, la naturaleza y Dios. Por tanto, siempre hay que tener presente que cuando habla de Dios en realidad está hablando de esa unión y no de un ser creador único con el poder de salvar u otorgar la felicidad a la raza humana, porque la libertad del hombre reside en la razón y en aceptar que todo está regido por unas leyes universales de las que formamos parte como lo hacemos de Dios. Es una visión que nos acerca a la naturaleza y al momento presente, de respeto, de admiración, de valorar lo que somos, lo que poseemos, lo que vemos, lo que sentimos, nuestro entorno, el resto de seres vivos, el cosmos... y dejar de pensar en una salvación de nuestra alma cuando nuestra existencia en la Tierra ya haya desaparecido.

Aunque los pensamientos de Spinoza y Heráclito están alejados de las enseñanzas del maestro Lao-Tse, podemos apreciar que la idea de que el hombre forma parte de la naturaleza, depende y se ve regido por ella, si está presente en sus escritos. También nos encontrarnos con la idea, de que el hombre forma parte de un Todo, y formamos parte de las obras que él, en este caso llamado Dios, realiza. La libertad del hombre viene dada por el razonamiento.

Heráclito cree que todo está en constante cambio y la fuerza de los opuestos crea el movimiento y rige el mundo, hay una permanente guerra de contrarios, que le ayuda a fluir. Para él, no es un fluir caótico ni desorganizado porque viene controlado por el Logos, el cual está presente y nos habla, pero sólo algunas personas son capaces de percibirlo.

Este cambio o devenir viene marcado por el elemento fuego, pero no estamos hablando de un modo literal, se basa en la transformación de la materia y el movimiento que esta confrontación de opuestos lleva a cabo.

\footnotetext{
${ }^{31}$ https://es.wikipedia.org/wiki/Pante\%C3\%ADsmo (30/07/2015 a las 08:28h).
} 
Gaston Bachelard también dedica un libro al elemento fuego como parte del ser, como una fuerza que se encuentra en nuestro interior, que tiene la capacidad de transformarnos tanto a nivel mental, espiritual... que puede poseernos con las pasiones, los odios y que puede llegar a consumirnos y destruirnos; o que por el contrario nos puede proporcionar la candidez del hogar, del amor, de la digestión, de la cocina... Por tanto, el fuego en sí es contradictorio, puede purificar o destruir, nacer o consumirse, doblegarse 0 descontrolarse...

- "Brilla en el Paraíso. Abrasa en el Infierno. Dulzor y tortura. Cocina y apocalipsis. El fuego es placer para el niño sentado prudentemente cerca del hogar; $y$, sin embargo, castiga toda desobediencia cuando se quiere jugar demasiado cerca con sus llamas". ${ }^{32}$

Como podemos observar hasta el momento, no existen unas diferencias tan notables como podíamos pensar en un primer acercamiento entre las ideas que envuelven al panteísmo y las ideas plasmadas en el I Ching. El Libro de las mutaciones. Hallamos coincidencias en varios aspectos: en el devenir de los opuestos, en el movimiento y la transformación continua y en que nada es cien por cien de una manera, que en el bien se aloja el mal, en la oscuridad la luz... que no pueden existir el uno sin el otro.

Para Spinoza el hombre es una parte más de la naturaleza y ve erróneo el concepto de religión actual porque en ella, el hombre es quien posee el control, incluso la capacidad de purificar su alma y otorgarle la salvación y la vida eterna.

- "La naturaleza es conocida por sí misma y no por ninguna otra cosa. Ella consta de infinitos atributos, cada uno de los cuales es infinito y perfecto en su género, y a cuya esencia pertenece la existencia. De ahí que, fuera de ella, ya no existe otra esencia o ser, y coincide, por tanto, exactamente con la esencia de Dios, único excelso y bendito". ${ }^{33}$

Para Spinoza la idea de religión tal y como la conocemos nace de las necesidades erróneas del hombre por encontrar en la naturaleza cosas que le beneficien porque cree que la naturaleza está para servirles. Gracias a la ignorancia de la gente, este planteamiento puede mantenerse. En la religión el hombre tiene la posibilidad de expiar sus pecados y alcanzar la felicidad que

\footnotetext{
${ }^{32}$ BACHELARD, Gaston. "Psicoanálisis del fuego". Ed. Alianza. Madrid, 1.966 . Pág. 18.

${ }^{33}$ SPINOZA. "Tratado breve". Alianza editorial. Madrid, 1990. Pág. 170. 
según Aristóteles es el fin de todo hombre. Pero para Spinoza el hombre de una manera individual y sin ser consciente del lugar que ocupa en el mundo, sin seguir las leyes universales, nunca podrá alcanzar la felicidad ni la salvación. Para ello, debe de guiarse por la razón.

"Ahora vemos, pues, que, dado que el hombre es una parte de toda la naturaleza, de la que depende y por la que también es regido, no puede hacer nada por sí mismo para su salvación y felicidad". ${ }^{34}$

De una manera errónea el intento de ser felices nos lleva a rezar y adorar a dioses y posteriormente a supersticiones que no son el comportamiento ni el pensamiento adecuado para el hombre porque para Spinoza, Dios no hace las cosas con un fin. La religión para él, es una manera de sumisión. Por tanto, critica este comportamiento porque la idea de que la naturaleza y Dios existen para servirnos no es cierta, y está basada en la ignorancia del pueblo, y la ignorancia siempre lleva a la servidumbre, con la que Spinoza está en desacuerdo. La naturaleza es la madre de la existencia y formamos parte de ella. Dios es la esencia existente y creadora y la naturaleza no es creada por Dios para llegar a fines concretos, sino porque está en su esencia. Todo es Uno. Sus pensamientos son similares a los expresados anteriormente, donde mencionábamos que, el ser humano en vez de proteger, respetar y comprender la naturaleza porque forma parte de ella, se creía con capacidad para dominarla y pensaba que estaba por encima de ella.

Spinoza cree que el hombre juzga tanto a sus semejantes como a todo lo que le rodea porque se cree el centro de todo y cree poder explicar la naturaleza de los fenómenos y las cosas, y ese planteamiento no es correcto. Al observar el comportamiento de los animales se puede apreciar claramente que el hombre forma parte de la naturaleza, porque nos regimos por instintos, por pasiones ocultas. Todos los seres poseen en su interior una luz que nos acompaña desde el momento de nuestra existencia hasta la eternidad. Es una fuerza o energía interna que persiste en nosotros aunque nuestro cuerpo-alma se vea corrompido por los placeres y vicios terrenales.

Spinoza otorga a la naturaleza varios nombres para poder diferenciar cuando hace referencia a Dios, a los atributos o a las ideas. Basándonos en la

\footnotetext{
${ }^{34}$ SPINOZA. “Tratado breve”. Op. Cit. Pág. 138.
} 
división que podemos encontrar en su obra titulada "Tratado breve" hemos realizado el siguiente esquema:

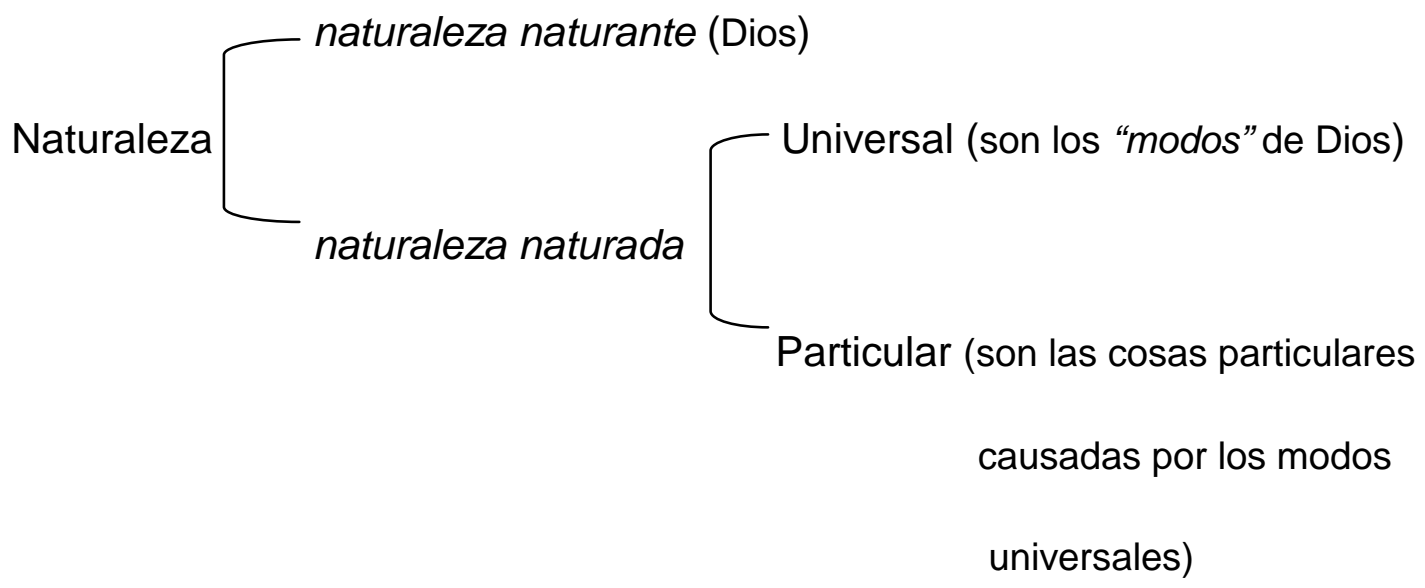

- " "(...) toda la Naturaleza naturada no es más que un único ser; pues de ahí se sigue que el hombre es una parte de la naturaleza, que debe estar en consonancia con las demás". ${ }^{35}$

Formamos parte de un Todo y ello nos lleva a la necesidad de estar en armonía con el resto de seres vivos, con el cosmos, con lo inanimado, con Dios...no existe esa visión antropocéntrica tan presente en nuestros días.

La idea de ser una especie superior capaz de dominar y doblegar a los demás seres vivos del planeta y a la propia naturaleza, es errónea, pues al hacerlo nos estamos condenando nosotros mismos, porque todos somos uno.

El ser humano desde tiempos antiguos se ha valido de dioses para explicar los fenómenos naturales que no tenían explicación en su momento, para sentirse seguro ante una naturaleza extraña que no eran capaz de controlar, comprender ni predecir. Los ritos a estos dioses creaban una especie de unión entre estos hechos inexplicables y el ser humano, formándose así, un vínculo de seguridad, protección, temor y respeto. El ser humano creía merecer la piedad y el servicio de estos dioses porque en cierta manera creía que era capaz de controlarlos y verse favorecidos por ellos. La ignorancia de las

\footnotetext{
${ }^{35}$ SPINOZA. "Tratado de la reforma del entendimiento/Principios de filosofía de Descartes/Pensamientos metafísicos". Alianza editorial. Madrid, 1988. Pág. 269.
} 
personas ayuda a mantener esta creencia y así el pueblo llano, es más manipulable y controlable a manos de personas ilustradas.

Tanto Dios como la naturaleza poseen gran número de atributos, y como ambos son infinitos, estos también lo serán. Aunque no hay que olvidar que nada existe por su propia materia o fuerza, sino es creada su esencia y existencia por Dios. 

2. Concepto propio de hombre-naturaleza basado en el estudio de la obra de Gaston Bachelard, Mircea Eliade y Levi-Strauss. 
El hombre ha sufrido una gran evolución desde su aparición en el planeta Tierra, hasta nuestros días, sobre todo debida a su capacidad de raciocinio. Esta capacidad, le ha permitido al hombre investigar, observar, imaginar, crear, reflexionar, pensar, evolucionar, relacionarse de una manera consciente además de instintivamente, con seres de su misma especie o de especies diferentes y con todo lo que le rodea.

Pero por muy avanzados intelectualmente que nos hallamos desarrollado, el hombre sigue siendo naturaleza, en cuanto que formamos parte de ella, al igual que los animales, los minerales y los vegetales. Interactuamos con ella, y participamos y sufrimos sus alteraciones y sus ciclos, dependemos de sus elementos para nuestra supervivencia.

Gaston Bachelard con títulos como "El agua y los sueños", "La poética del espacio", "Psicoanálisis del fuego", "El aire y los sueños: ensayo sobre la imaginación del movimiento", "La tierra y los ensueños de la voluntad"... nos acerca al mundo de los cuatro elementos unidos a los temores, ensoñaciones y vivencias de los hombres.

Esto se debe a que desde el mismo instante en que nacemos (da igual la época), el hombre queda expuesto a un sinfín de experiencias, sensaciones, emociones que nunca antes había experimentado. Pasamos de la protección del útero materno que nos otorga bienestar, seguridad y calor, a un universo extraño lleno de ruidos, luces, frío, movimiento... Cómo no podemos subsistir por nosotros mismos, nuestra vida queda en manos de terceras personas con la que nos comunicamos con medio de llantos, risas y enojos a falta de un lenguaje claro. En este momento de nuestra vida somos seres vulnerables y al igual que cualquier ser vivo, tenemos todo un mundo por descubrir. Hasta llegada una edad, nuestras emociones son las que mandan y tenemos una necesidad primordial de experimentar y de poner a prueba nuestros sentidos, con el fin de aprender y avanzar, y solemos hacerlo en soledad de una manera lúdica y divertida, y sin darnos cuenta, estamos creando los cimientos de la persona que seremos algún día.

Todas estas experiencias residirán en nosotros para siempre y basta con un olor, una visión, una sensación, para hacernos retornar a ellas, y volver a 
sentir las mismas emociones que cuando éramos niños. Según Gaston Bachelard: “(...) la permanencia en el alma humana de un núcleo de infancia, de una infancia inmóvil pero siempre viva, fuera de la historia, escondida a los demás, disfrazada de historia cuando la contamos, pero que sólo podrá ser real en esos instantes de iluminación, es decir en los instantes de su existencia poética,36.

Por tanto, el hombre adulto no ha madurado dejando atrás los años ya vividos y centrándose sólo en el presente o en el futuro, sino que el pasado de una manera u otra es nuestro compañero de viajes y de vez en cuando, salta en el tiempo para presentarse en nuestro presente más vivo que nunca.

- "Soñando con la infancia, volvemos a la cueva de las ensoñaciones, a las ensoñaciones que nos han abierto el mundo. La ensoñación nos convierte en el primer habitante del mundo de la soledad ${ }^{\text {,37. }}$.

Por tanto, no existe una línea de tiempo correlativa en el ser humano, al menos, no emocionalmente.

- "Sólo cuando el alma y el espíritu están unidos en una ensoñación por la ensoñación nos beneficiamos de la unión de la imaginación y la memoria. Sólo del tal unión podemos decir que revivimos nuestro pasado, que nuestro ser pasado se imagina que revive, ${ }^{38}$.

$Y$ de igual manera que el hombre revive sus recuerdos y estos momentos de soledad vividos en la infancia y permanecen con nosotros el resto de nuestra existencia, podemos ampliar esta visión en el tiempo y en el espacio, creando una unión entre el hombre primitivo y el hombre actual en cuanto que gran parte de las costumbres, ritos y mitos de nuestros ancestros han pasado a formar parte de nosotros mismos. Son acciones $u$ hechos aprendidos que han pasado de generación en generación hasta llegar a nuestros días.

No podemos saber a ciencia cierta cómo era el hombre primitivo porque todas nuestras conjeturas están basadas en el estudio e interpretación de los restos arqueológicos encontrados; huesos, pinturas, utensilios, pieles... pero

\footnotetext{
${ }^{36}$ BACHELARD, Gaston. "La poética de la ensoñación". Fondo de cultura Económica de México. México D.F, 1972. Pág. 151.

${ }^{37}$ BACHELARD, Gaston. "La poética de la ensoñación". Op. Cit. Pág. 155.

${ }^{38}$ BACHELARD, Gaston. "La poética de la ensoñación". Op. Cit. Pág. 158.
} 
eso sólo es la parte material y física, la parte emocional, social, de pensamiento, todo ello nos es ajeno porque por mucho que lo intentemos no hay forma física de volver al pasado y formar parte de este periodo.

Igual ocurre con el estudio e interpretación de los ritos y los mitos.

- “... cada día se descubre más que, para interpretar correctamente los mitos y los ritos, y aun para interpretarlos desde un punto de vista estructural (y nos equivocaríamos si lo confundiésemos con un simple análisis formal), es indispensable la identificación precisa de las plantas y de los animales de que se hace mención, o que son utilizados directamente en forma de fragmentos o de despojos, 39 .

El no saber el significado y el valor que cada cultura otorga a los diversos elementos que formaban parte del rito y por qué se realizaban en un lugar determinado y en un periodo de tiempo concreto, hace que no seamos capaces de llegar a entender ni a interpretar de manera correcta los rituales que realizaban nuestros ancestros o que se realizan en cualquier otro lugar del planeta.

Lo que sí sabemos, es que las cuevas fueron un espacio importante en sus vidas, puesto que les servía de protección, cobijo y además las utilizaban como lugar sagrado. En comparación, no distan tanto de las funciones que poseen las casas actuales, las cuales nos otorgan el bienestar y el descanso que nuestro cuerpo necesita después de una larga jornada laboral, porque nos sentimos protegidos y tranquilos en ellas.

- “(...) la casa alberga el ensueño, la casa protege al soñador, la casa nos permite soñar en paz".

- "La casa es un cuerpo de imágenes que dan al hombre razones o ilusiones de estabilidad"41

No obstante, al igual que no todas las zonas de la cueva estaba dotada de la misma significancia o simbolismo, nuestra casa, también presenta lugares que nos invitan a una ensoñación más profunda. $Y$ podemos hacer una distinción entre las cuevas, las casas de antaño y las actuales, porque el paso

\footnotetext{
${ }^{39}$ LEVI-STRAUSS, Claude. "El pensamiento salvaje". Fondo de cultura económica de México. México D.F, 1964. Pág. 76.

${ }^{40}$ BACHELARD, Gaston. "La poética del espacio". Fondo de cultura de México-Buenos Aires. México, 1965. Pág. 38.

${ }^{41}$ BACHELARD, Gaston. “La poética del espacio”. Op. Cit. Pág. 51.
} 
de los años ha hecho que se perdiera en gran medida esa misticidad 0 concepto de lugar sagrado. Las casas de antaño todavía poseían esa unión mística con la presencia del sótano, la escalera, el desván, el jardín y la buhardilla, que aportaba diferentes sentimientos a sus inquilinos, pero ahora con la mecanización y la industrialización, los espacios más reducidos, el hacinamiento en pisos, se ha perdido toda esa magia. La sociedad industrial ha terminado con esos lugares sagrados. En la actualidad, según Le Corbusier, la casa es una <<máquina de residir>>. Se alinea, pues, entre las innumerables máquinas producidas en serie en las sociedades industriales. La casa ideal del mundo moderno debe ser, ante todo, funcional, es decir, debe permitir a los hombres trabajar y descansar para asegurar su trabajo. Se puede cambiar de <<máquina de residir >> con tanta frecuencia como se cambia de bicicleta, de nevera o de automóvil ${ }^{42}$.Las relaciones sociales también se han visto alteradas por nuestro cambio de vida, hemos pasado de relacionarnos ante el fuego a apenas conocer a nuestros vecinos. Hemos cambiado el aire puro, por el aire viciado y contaminado de las ciudades y nos hemos dejado llevar por una ilusión de vida que no nos pertenece.

- "Los edificios no tienen en la ciudad más que altura exterior. Los ascensores destruyen los heroísmos de la escalera. Ya no tienen ningún mérito vivir cerca del cielo. Y él en sí no es más que una horizontalidad. A las diferentes habitaciones de una vivienda metida en un piso le falta uno de los principios fundamentales para distinguir y clasificar los valores de intimidad.

A la ausencia de valores íntimos de verticalidad, hay que añadir la falta de cosmicidad de la casa de las grandes urbes. Allí las casas ya no están dentro de la naturaleza. Las relaciones de la morada y el espacio se vuelven facticias. Toso es máquina y la vida íntima huye por todas partes". ${ }^{43}$

No somos más libres que nuestros antepasados ni tenemos mayor control sobre lo que nos rodea, porque si antes el problema era los efectos de la naturaleza, ahora son los hombres con poder quien dirigen nuestras vidas.

Era más fácil adorar a las divinidades de las aguas, de la montaña, el sol... y asegurar por medio de rituales y tributos una feliz cosecha, una vida

\footnotetext{
${ }^{42}$ LE CORBUSIER, citado por Mircea Eliade en "Lo sagrado y lo profano". Ed. Paidós Orientalia. L’Hospitalet de Llobregat. Barcelona, 2009. Pág. 42.

${ }^{43}$ BACHELARD, Gaston. "La poética del espacio". Op. Cit. Pág. 62.
} 
tranquila, una temperatura y precipitaciones óptimas que confiar en una sociedad capitalista donde el consumo es a lo único que uno aspira.

Tampoco todas las casas son iguales, porque la casa de nuestra infancia nos marca para el resto de nuestra vida. Ella es nuestro segundo hogar después de la seguridad del vientre materno, y eso nos une a ella con un cordón umbilical invisible que permanecerá para siempre.

Según Gaston Bachelard la vida empieza bien, empieza encerrada, protegida, toda tibia en el regazo de una casa ${ }^{44}$.

Una vez realizado el estudio sobre el hogar, debemos centrarnos en la comparativa del hombre primitivo y el hombre actual, donde no existe una rotura en la historia que nos haga pensar que parte de ese hombre arcaico no esté presente y forme parte de la actual humanidad, pues somos su evolución. Los estudios de Charles Darwin colocaron al ser humano en la misma cadena evolutiva que a las demás especies del planeta. Todos los seres vivos quedaron equiparados biológicamente y de estos estudios nació, The Origins of Species en 1859.

Según la teoría de la evolución de Darwin: "Los tipos biológicos 0 especies no tienen una existencia fija ni estática sino que se encuentran en cambio constante.

La vida se manifiesta por una lucha constante por la supervivencia. La lucha constante provoca que los organismos que menos se adaptan a un medio natural específico desaparezcan y permite que los mejor adaptados se reproduzcan, a este proceso se le llama "selección natural". La selección natural, el desarrollo y la evolución requieren de un enorme periodo de tiempo, tan largo que en una vida humana no se pueden apreciar estos fenómenos" ${ }^{\star 45}$.

Por tanto, el ser humano, aunque debido a nuestro antropocentrismo nos creamos el centro de todo, no somos más que un eslabón más en la cadena evolutiva. El ser actual es la evolución a lo largo del tiempo del ser que habitaba en las cuevas, que realizaba pinturas en ellas y ritos sagrados, que

\footnotetext{
${ }^{44}$ BACHELARD, Gaston. "La poética del espacio". Op. Cit. Pág. 39.

${ }^{45}$ http://redescolar.ilce.edu.mx/redescolar/act_permanentes/historia/histdeltiempo/mundo/ prehis/t_teoesp.htm (15/1/2.010 a las 10'26h).
} 
cazaba y recolectaba para sobrevivir, que una vez tuvo el poder y el conocimiento para crear y controlar el fuego fue capaz de cocinar, calentarse, sociabilizarse y ampliar las horas de luz y posteriormente aprendió a utilizar los metales mediante la fundición lo que supuso el comienzo de una serie de cambios que impulsados por el ansia de conocimiento llevaron al hombre a lo que se ha denominado revolución industrial, aumentando la brecha entre hombre y naturaleza.

Actualmente, el hombre, tiene una visión altiva de él frente a sus ancestros. Somos tan egocéntricos que ya no nos basta con no sentir hermandad con el resto de seres vivos, nos cuesta reconocer nuestros orígenes y no queremos que se nos relacione con el hombre primitivo o con las tribus denominadas "salvajes", porque creemos que son rudas, toscas, fuertes, poco inteligentes,... es una negación a nuestros orígenes porque nos da miedo, nos asusta que nuestros genes lleven implícitos parte del hombre primitivo. Por eso, los equiparamos con el resto de especies de animales las cuales se rigen por los sentidos y el instinto, creando una brecha entre el hombre del pasado y el hombre del presente. Así, nos sentimos seguros pensando que somos el centro del universo y somos capaces de controlarlo todo.

-(...) nunca en ninguna parte el "salvaje" ha sido, sin la menor duda, ese ser salido apenas de la condición animal, entregado todavía al imperio de sus necesidades y de sus instintos, que demasiado a menudo nos hemos complacido en imaginar $y$, mucho menos, esa consciencia denominada por la afectividad y ahogada en la confusión y la participación. Los ejemplos (...) testimonian a favor de un pensamiento entregado de lleno a todos los ejercicios de la reflexión intelectual, semejante a la de los naturistas y los herméticos de la Antigüedad y de la Edad Media,46.

Su mundo está estrechamente ligado a símbolos, ritos y mitos, que les proporcionan una comunicación directa con los diferentes dioses. Normalmente es la figura del chamán quien es el encargado de esta misión, ya que posee la capacidad de interconectar con ellos.

Pedían protección, cubrir sus necesidades básicas y otorgaban gran relevancia a la fertilidad y al sexo.

\footnotetext{
${ }^{46}$ LEVI-STRAUSS, Claude. “El pensamiento salvaje”. Op. Cit. Págs. 69 y 70.
} 
Todo el clan o tribu, participaba de una manera activa en estos rituales, donde cada elemento de la sociedad tenía su función y debía seguir con sus obligaciones como el resto de los presentes.

Esto se debe a que hay una sacralización por parte del hombre primitivo ante los fenómenos naturales y ante las relaciones con el entorno. Actualmente, esa visión sacra, de todo lo que nos rodea ha desaparecido conforme la brecha entre hombre y naturaleza ha ido creciendo. Vivimos en una sociedad con base religiosa, pero no todo el mundo es creyente, hay practicantes de la fe, hay ateos y agnósticos. Nos esforzamos por separarnos de la religión porque tenemos un pensamiento más centrado en la historia, en cuanto a datos y fechas concretas. En muchos casos lo que no somos capaces de percibir de una manera lógica, física y material, no nos aporta la seguridad que necesitamos. No creemos en aquello que no podemos percibir y por tanto, se rompe esa comunicación con lo divino, con lo celestial, con el cosmos, con lo universal, pero el ser profano ha sido un "invento reciente", los seres humanos hemos venido arrastrando toda una serie de costumbres, fiestas, celebraciones... que han podido modificarse con el paso del tiempo para adaptarse a la época y al momento histórico y social en el que se realizaban, pero su esencia ha seguido intacta.

- "(...) el mundo profano en su totalidad, el cosmos completamente desacralizado, es un descubrimiento reciente del espíritu humano. (...) la desacralización caracteriza la experiencia total del hombre no religioso de las sociedades modernas; del hecho de que, por consiguiente, este último se resiente de una dificultad cada vez mayor para reencontrar las dimensiones existenciales del hombre religioso de las sociedades arcaicas, ${ }^{, 47}$.

No hay que olvidar que el ser humano profano, parte de una cultura y unas raíces religiosas. Las fiestas de nuestro calendario están basadas en la religión y prácticamente todo el mundo las celebra, con lo que se está participando activamente en esos ritos que desde la vertiente intelectual se niegan.

“(...) el hombre que opta por una vida profana no logra abolir del todo el comportamiento religioso, 48 .

\footnotetext{
${ }^{47}$ ELIADE, Mircea. "Lo sagrado y lo profano". Op. Cit. Pág. 16.

${ }^{48}$ ELIADE, Mircea. "Lo sagrado y lo profano". Op. Cit. Pág.23.
} 
- “(..) el hombre profano es el descendiente del homo religiosus y no puede anular su propia historia, es decir, los comportamientos de sus antepasados religiosos, que lo han construido tal como es hoy día. Y tanto más cuanto que una gran parte de su existencia se nutre de los impulsos procedentes de lo más hondo de su ser, de esa zona que se ha dado en llamar el inconsciente. Un hombre exclusivamente racional es una mera abstracción: jamás se encuentra en la realidad"49

Los lugares sagrados se mantienen vivos en nuestra sociedad; templos, ermitas, iglesias, catedrales... allí se sigue realizando el culto a la divinidad. Se convierten en espacios especiales donde podemos tener una conexión con lo divino y se convierten en espacios atemporales donde se siguen manteniendo el culto y los ritos ancestrales-actuales.

Es como un lugar aislado dentro de la sociedad que nos permite diferenciar entre espacio sagrado y espacio profano.

Para el no creyente todos los lugares son sagrados, carentes de magia.

- “(..) para el hombre profano, el espacio es homogéneo y neutro: ninguna ruptura diferencia cualitativamente las diversas partes de su masa,50.

Al igual que el profano, no puede huir del todo de lo sagrado, el hombre contemporáneo, no puede dejar atrás sus orígenes, ni años de evolución.

El hombre primitivo, era un ser creativo y hacedor en cuanto que era capaz de expresarse mediante signos, pinturas y dibujos, y tenía la necesidad de experimentar y de crear. Este comportamiento no dista tanto de los niños que aunque no puedan comunicarse con un lenguaje fonético claro o mediante la escritura, pasan su tiempo en un continuo aprendizaje, gracias a la observación, reflexión, experimentación, manipulación de diferentes materiales...

- “(..) la infancia está en los orígenes de los mayores paisajes. Nuestras soledades de infancia nos han dado las inmensidades primitivas.

Soñando con la infancia, volvemos a la cueva de las ensoñaciones, a las ensoñaciones que nos han abierto el mundo. La ensoñación nos convierte en el primer habitante del mundo de la soledad, ${ }^{151}$.

La imaginación y el arte, juegan un papel muy importante en el desarrollo físico y mental del ser humano. La imaginación nos hace libres, nos traslada a lugares increíbles, nos ofrece las mejores historias jamás relatadas,

\footnotetext{
${ }^{49}$ ELIADE, Mircea. "Lo sagrado y lo profano". Op. Cit. Pág. 152.

${ }^{50}$ ELIADE, Mircea. "Lo sagrado y lo profano". Op. Cit. Pág.22.

${ }^{51}$ BACHELARD, Gaston. "La poética de la ensoñación". Op. Cit. Pág. 155.
} 
nos permite crear personajes, animales, mundos... y siempre nos acompaña. Forman parte de esos momentos de soledad que tanto nos marcan en la infancia, donde sólo nos acompaña nuestra imaginación y dejamos que fluya toda una serie de hechos irreales, de sueños, de deseos, de miedos, de pasiones, de fantasía y nos dejamos arrastrar por mundos irreales, donde podemos ser héroes o villanos, hadas, brujas o princesas.

- "Mil veces la sabiduría popular ha significado la importancia de la imaginación incluso para la salud del individuo, para el equilibrio y la riqueza de su vida interior. Algunas lenguas modernas siguen considerando a quien $<<c a r e c e$ de imaginación >> como un ser limitado, mediocre, triste, un pobre desgraciado,52

Los lugares donde pasamos esos ratos de soledad suelen marcarnos para siempre, se convierten en espacios especiales donde regresaremos en nuestras ensoñaciones. Da igual que sea una zona de la casa natal, una cueva o un lugar frente al fuego, ese momento de liberación, de bienestar y de sueños, quedarán grabados en nosotros para siempre.

Es un recuerdo de una época en el que las obligaciones y las responsabilidades no ocupaban gran parte de nuestro tiempo y no sufríamos estrés, ni ansiedad, ni agotamiento laboral, nuestros quehaceres eran más simples, observábamos, aprendíamos, experimentábamos, imaginábamos, nos divertíamos y el tiempo no corría a la misma velocidad, era más pausado.

El arte siempre ha estado presente en nuestro desarrollo, quien no ha visto a un niño dibujar con un palo en el barro, apilar objetos en forma de torre, mancharse las manos y plasmarlas en cualquier superficie o pintarse la cara. Estos son claros ejemplos de que de manera inconsciente, el ser humano es un ser expresivo, artístico y plástico.

En la sociedad actual, el arte va perdiendo la importancia que tuvo en otras épocas, para quedar relegado a un segundo plano frente a materias creadas por el hombre como la informática, la robótica, la mecánica, etc.

Perdemos nuestros lazos con la naturaleza, con nuestros instintos y nos dejamos arrastrar por una cultura industrializada y capitalista.

\footnotetext{
${ }^{52}$ ELIADE, Mircea. “Imágenes y símbolos”. Ed. Taurus Humanidades. Madrid, 1999. Pág. 19.
} 
Nos separa cada vez más de nuestros ancestros que pintaban imágenes en las cuevas, pero no hay que olvidar que el arte al igual que muchas acciones y ritos que podemos encontrar en nuestros días, también son la evolución de aquel periodo.

El arte no ha logrado extirparse del todo ese carácter sacro que le envolvía en sus primeros tiempos. Puede que los artistas sean una especie de chamanes capaces de transmitir, desvelar, abrir la mente y crear sentimientos en los espectadores que admiran sus obras, pero el proceso de elaboración por el cual el artista, se enfrenta al material en soledad, como hemos visto anteriormente, también crea un momento mágico, sagrado y de ensoñación.

Para Mircea Eliade un artista que sería un claro ejemplo de lo nombrado anteriormente, sería Brancusi.

- “(...) trata la piedra con la sensibilidad, y quizás la veneración, de un hombre de la prehistoria. La paciencia, atención, alegría con las que cincelaba sus obras hasta que transformaba las superficies en espejos ondulados-de tal modo que uno desearía acariciarlas-, el tiempo que prodigaba en cincelar innumerables réplicas de tantas de sus obras sería para mí inexplicable si no adivinara en ese largo y monótono trabajo la beatitud que proporciona la intimidad indefinidamente prolongada con la materia cristiana,53

La imaginación y las necesidades del hombre por crear y sobrepasar sus conocimientos en todas sus facetas, contengan buenos o malos ideales, hace que el mundo este en un constante cambio.

Algunas personas volcaron ese conocimiento hacia una faceta donde el metal y los minerales poseían poderes extraordinarios y basaban su vida en su estudio, desarrollo y elaboración. Estamos hablando de los alquimistas.

La alquimia es una ciencia que se basa en la creencia de que la materia se puede curar, transformar y perfeccionar. El elemento fuego, se convierte en el aliado principal de los alquimistas, lo que nos hace retomar la unión con el hombre primitivo, donde como hemos comentado, el fuego para ellos, era de suma importancia puesto que, era el único elemento que podía crear y controlar. El fuego alquímico está cargado de sexualidad, pues es la parte

\footnotetext{
${ }^{53}$ ELIADE, Mircea. "El vuelo mágico". Ediciones Siruela. Madrid, 1995. Pág. 155.
} 
masculina y la tierra y el agua, la femenina. También se ha estudiado el origen del fuego como un frotamiento sexual por parte de nuestros ancestros.

- "El ensayo objetivo de producir fuego mediante el frotamiento es sugerido por experiencias perfectamente íntimas. En todo caso, por este lado es más corto el circuito entre el fenómeno del fuego y su reproducción. El amor es la primera hipótesis científica para la reproducción objetiva del fuego, ${ }^{, 54}$.

La Tierra era por tanto, un ser femenino que albergaba en su útero los minerales y los metales, allí, estos se formaban, crecían, se desarrollaban y morían.

Vuelve a darse una similitud con la función de las cavernas en la época prehistórica donde estas también hacían de madre protectora de sus inquilinos, les otorgaba un lugar espiritual y de recogimiento.

- “(..) las grutas y las cavernas eran asimiladas también a la matriz de la Madre Tierra. El papel ritual de las cavernas, probado en la prehistoria, podría interpretarse igualmente como un retorno místico al seno de la $<<$ Madre $>>$, lo que explicaría tanto las sepulturas en las cavernas como los ritos de iniciación verificados en estos mismos lugares, 55 .

Los mineros eran los encargados de extraerlos del interior de su madre como si de un parto se tratara y posteriormente, si estaban poco madurados, se utilizaban los calderos aplicándoles una temperatura adecuada, como si de una bolsa marsupial se tratara. En ellos, esos embriones, llegaban a convertirse en adultos.

No son trabajos científicos, ni químicos, ni se pueden comparar con estas ciencias, porque la alquimia, busca la pureza y el alma de la materia, por medio de una ensoñación hecha realidad. Hay una fe, una creencia, una espiritualidad que envuelve al alquimista, por medio de la unión del estudio, la ensoñación y la ciencia.

El alquimista, cree que existe la manera de crear un elemento con el poder de salvar el mundo. De otorgar la salvación a todas las especies y a la propia naturaleza. Estamos hablando de la "piedra filosofal".

\footnotetext{
${ }^{54}$ BACHELARD, Gaston. "Psicoanálisis del fuego". Op. Cit. Pág. 43.

${ }^{55}$ ELIADE, Mircea. "Herreros y alquimistas". Op. Cit. Pág. 40.
} 
- "Según los alquimistas, el cristianismo ha salvado al hombre, pero no a la naturaleza. El alquimista sueña con curar el mundo en su totalidad: la piedra filosofal es concebida como el Filius Macrocosmi que cura el mundo. El fin último de la <<obra>> alquímica es la apokatastasis, la Salvación cósmica,56.

Buscaban lo que se ha catalogado como la "vida eterna o paraíso", porque si hay algo que se mantiene como una constante desde la aparición del hombre en el planeta hasta nuestros días, es el estudio, miedo y respeto hacia los conceptos de vida, muerte y resurrección. Los ritos, las creencias, han pasado de generación a generación con el fin de que hallemos el camino en nuestra vida mortal, para que después de la muerte, seamos participes del reino de los cielos y podamos hallar el bienestar, la salvación, la reencarnación... El hombre primitivo poseía divinidades de la montaña, las aguas, el sol... y realizaba ritos para mantener contentas a los dioses pensando de alguna manera que podía comunicarse con ellos y controlarlos con ofrendas o sacrificios. El indígena, realizaba ceremonias donde se les asignaba un animal totémico a los iniciados que consigan convertirse en adultos para que les diera sus cualidades y los protegiera.

- "Los indígenas tenían el sentimiento muy vivo de una afinidad física y psicológica entre los hombres y sus tótems, y de la obligación correspondiente, a cada grupo, de perpetuar un tipo de conducta, ${ }^{, 57}$.

El hombre cristiano ve la vida como un tránsito hacia un lugar mejor, la muerte es un trámite un despojo del cuerpo físico para alcanzar la eternidad y la espiritualidad. Sólo necesita haberse comportado correctamente durante su fase mortal, como puede ser; ayudando al prójimo o no cometiendo actos impuros. Así, conseguirá albergar un alma pura para acceder al reino de los cielos.

En Oriente, se encuentran como ya hemos comentado anteriormente, diversas filosofías; el budismo, el taoísmo, el confucionismo... Todas ven el paso por la vida mortal como un camino de estudio en el cual conseguir alcanzar la espiritualidad.

Por tanto, no existe una brecha ni una separación histórica entre nuestros ancestros y nosotros, son la base de nuestra especie, somos su

\footnotetext{
${ }^{56}$ JUNG citado por Mircea Eliade. "El vuelo mágico". Op. Cit. Pág. 98.

${ }^{57}$ LEVI-STRAUSS, Claude. "El pensamiento salvaje”. Op. Cit. Pág. 171.
} 
evolución. Provenimos de un mundo de ritos, mitos y cultos religiosos y mágicos.

- "No hay religión sin magia, como no hay magia que no contenga, por lo menos, un poco de religión, 58 .

- "El comportamiento mágico-religioso de la humanidad arcaica revela, en el hombre, una toma de conciencia existencial con respecto al Cosmos y a sí mismo.

(...) una metafísica, es decir, una concepción global y coherente de la Realidad, y no una serie de gestos instintivos regidos por la misma y fundamental <<reacción del animal humano ante la naturaleza>>,59.

Por tanto, la visión del hombre primitivo como un ser instintivo, con apenas capacidad para relacionarse y ser consciente del mundo que le rodeaba, deja paso a una labor de observación, de reflexión, de estudio y de comprensión ante la naturaleza.

${ }^{58}$ LEVI-STRAUSS, Claude. “El pensamiento salvaje”. Op. Cit. Pág. 321.

${ }^{59}$ MIRCEA, ELlade. "Imágenes y símbolos”. Op. Cit. Págs. 189 y 190. 
3. La naturaleza del "hombre-artista". Comparación arte oriental y occidental. 
Al hablar del arte oriental, hemos basado nuestro estudio principalmente en el arte de Japón y China, al igual que cuando nos referimos a Occidente, hemos reducido nuestro estudio a Italia, Alemania, Inglaterra, Francia y España.

El periodo en que está ubicado nuestro estudio, es anterior a la era de la globalización por creer que esta unificación de culturas, de sociedades, de políticas, de economías, aspiraciones y tecnologías, hacen que las tradiciones antiguas y las verdaderas raíces de cualquier país se vean demasiado viciadas por la conexión con el resto del mundo y su interdependencia.

Desde que el hombre apareció en el planeta Tierra, ha sido un ser creativo, no importa el tipo de arte que hiciera ni lo que representara, pero ha sido capaz de expresarse de una manera plástica. Con palos, ramas, barro, pigmentos sacados de la naturaleza... podemos decir que es una cualidad innata en nosotros. Dependiendo de la zona geográfica, la cultura, la política, la filosofía, la religión, etc. nos encontraremos a lo largo de la historia ante un tipo de arte u otro.

En nuestro caso, vamos a desarrollar una comparativa a rasgos generales entre el arte oriental y el arte occidental. Una visión del arte (más oriental) como camino frente a una visión del arte (más occidental) como proyección del artista.

Existen grandes diferencias entre el arte occidental y el arte oriental, esto se debe principalmente, a que el arte no es un elemento aislado e inalterable, se ve afectado como hemos comentado anteriormente, por los cambios que se producen a su alrededor, tanto políticos, culturales, sociales, psicológicos y por tanto, también por el periodo histórico y el lugar geográfico.

Es complicado desde el punto de vista occidental, entender y comprender el arte oriental, el cual se basa en una cultura y unas costumbres que nos son ajenas. Por mucho que intentemos ponernos en su lugar, no alcanzaremos a captar sus obras en su justa medida, ni entenderemos el valor espiritual que cohabita en ellas. Lo mismo debe de suceder a la inversa, el arte occidental con ese sentimiento de búsqueda continua que en ocasiones lleva a la 
desaparición de los cánones del estilo predecesor, debe de resultar cuanto menos chocante a una cultura que basa su arte en el aprendizaje y realización de copias de los grandes maestros de obras realizadas en tiempos antiguos. Sólo podrán acceder a la originalidad cuando controlen la copia de estos grandes artistas. Y no una originalidad tal y como se plantea en Occidente, sino un estilo propio, pero basándose en su aprendizaje. Esto no quiere decir que en Occidente no se valore el arte anterior a nuestro tiempo y que no se realicen copias de los grandes maestros como medio de aprendizaje, sino que nuestro concepto de originalidad va más unido a nuestro ego como artistas y a nuestro afán por destacar, ser reconocido y recordado.

- "Copiar los originales o imitar el estilo de un maestro no tiene ese alcance negativo que atribuimos entre nosotros y son un homenaje retrospectivo, decidido a garantizar una más alta perfección artística, ${ }^{, 00}$.

Esto no sólo sucede en el ámbito de la pintura, sino que se amplía al resto de especialidades artísticas, como es por ejemplo el caso de la cerámica china.

- "(...) al estar poco desarrollada en el espíritu chino la necesidad de una originalidad creadora, los ceramistas se adaptaron sin dificultad a la repetición o a la reproducción, incluso a distancia de siglos, de las más antiguas formas ya exportadas y arraigadas aun cuando hubieran caído en desuso,61

Las diferencias entre un arte y otro, también están condicionadas porque Oriente, sobretodo Japón, hasta el siglo XIX era un país encerrado en sí mismo, con poco contacto con el exterior. Hubo un periodo de varios siglos antes donde si hubo influencias por parte sobre todo de los ingleses, porque sus fronteras se abrieron al exterior pero posteriormente, las fronteras se cerraron y durante siglos no volvieron a abrirse, lo que hace que posea una cultura más pura y un arte más profundo, basado en sus creencias. Por otra parte, Occidente si tiene abiertas sus fronteras y se pueden apreciar influencias entre los distintos países europeos.

Para los artistas occidentales del siglo XIX el arte oriental fue todo un descubrimiento, vieron en él la manera de enriquecer su arte, estamos

\footnotetext{
${ }^{60}$ PISCHEL, Gina. "Breve historia del arte chino". Ed. Labor, S.A. Barcelona 1967. Pág. 7

${ }^{61}$ PISCHEL, Gina. "Breve historia del arte chino". Op. Cit. Pág. 24
} 
hablando de un periodo de "vanguardias", donde se intentaba llevar al límite todo canon establecido.

- " (...) aliado que los impresionistas encontraron en su atrevida búsqueda de nuevos temas y nuevos esquemas cromáticos fue la estampa coloreada japonesa,62.

Estas estampas llegaron a Occidente en el siglo XIX, y tuvieron mucha aceptación sobre todo por parte de los impresionistas que incluso las coleccionaban.

- "Cuando el Japón se vio obligado, a mediados del siglo XIX, a entrar en relaciones comerciales con Europa y América, esas estampas se emplearon a menudo para envolver y para rellenar paquetes, y podían encontrarse muy baratas en las tiendas de té. Artistas del círculo de Manet fueron los primeros en apreciar su belleza y en coleccionarlas ávidamente. Aquí hallaron una tradición no corrompida por aquellas reglas académicas y aquellas rutinas de las que se esforzaron en zafarse los pintores franceses. Las estampas japonesas tuvieron preferencia por las representaciones de aspectos insólitos y espontáneos del mundo. (...) Fue este atrevido desdén de una regla elemental de la pintura europea lo que sugestionó a los impresionistas. Descubrieron en esta regla un último reducto del antiguo predominio del conocimiento sobre la visión,63.

Pero no sólo fueron los pintores los que se vieron atraídos por el arte oriental, también los arquitectos se vieron influenciados por el arte del Extremo Oriente. Ejemplo de ello, son las construcciones de Víctor Horta.

- "Horta aprendió del arte japonés a descartar la simetría, introduciendo las líneas curvas del arte oriental. Pero no fue un mero imitador, sino que trasladó estas líneas a las estructuras de acero, que tan bien se acomodaban a las exigencias modernas ${ }^{, 64}$.

\footnotetext{
${ }^{62} \mathrm{GOMBRICH}$, Ernst H. “Historia del arte”. Alianza Editorial. Madrid, 1982. Pág. 441.

${ }^{63} \mathrm{GOMBRICH}$, Ernst H. "Historia del arte". Op. Cit. Págs. 441 y 442.

${ }^{64} \mathrm{GOMBRICH}$, Ernst H. "Historia del arte". Op. Cit. Págs. 450 y 451.
} 


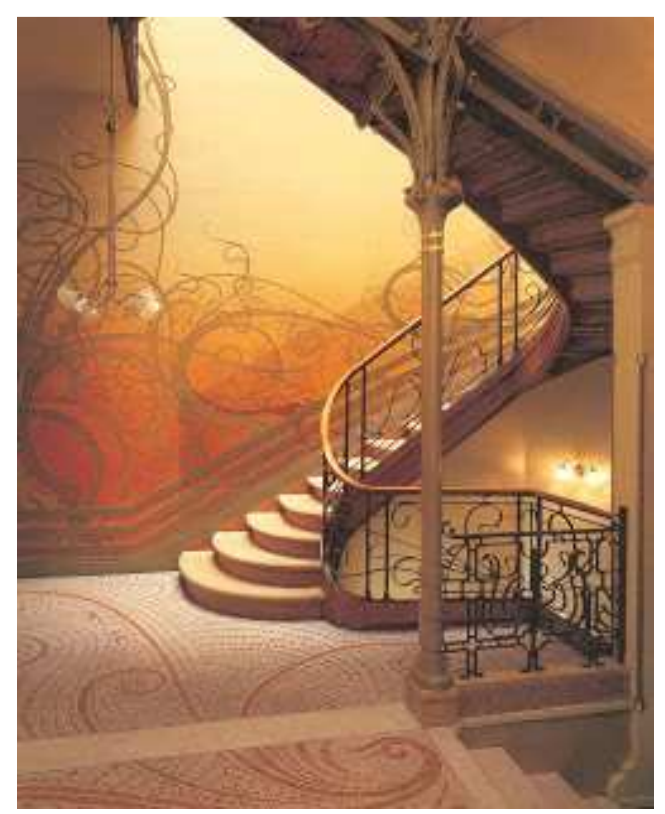

Ilustración 7. Casa Tassel (Escaleras). Victor Horta

Otras diferencias notables entre el arte oriental y occidental, las encontramos en la temática, la resolución técnica, el color y su clasificación en cuanto al término "artes menores".

La temática principal en el arte oriental, es la naturaleza. En ella están basadas casi todas las obras, más concretamente en el paisaje, aunque también se realiza un notable número de arte floral y animal. En China se recrean los fenómenos naturales (el viento, la lluvia...). El cuerpo humano cuando aparece representado no lo hace como elemento principal pues al encontrarse ubicado entre el cielo y la tierra, forma parte del concepto oriental de naturaleza y se iguala en importancia al resto de fenómenos y seres vivos.

- "La concepción de la naturaleza, diferente de la occidental, determina la estética del arte del Extremo Oriente en general. La simbología de los elementos de la naturaleza se basa en la teoría de no- jerarquización de aquellos. En China la palabra naturaleza significa <<todo lo que hay entre el cielo y la tierra >>, incluyendo tanto al hombre como a una brizna de hierba, un insecto, una montaña, el viento o la lluvia, como queda plasmado en esta pintura de Ren Xun,65.

\footnotetext{
${ }^{65} \mathrm{KIM}$, Sue-Hee. "El arte del Extremo Oriente". Ed. Anaya. Madrid, 1993. Pág. 4.
} 


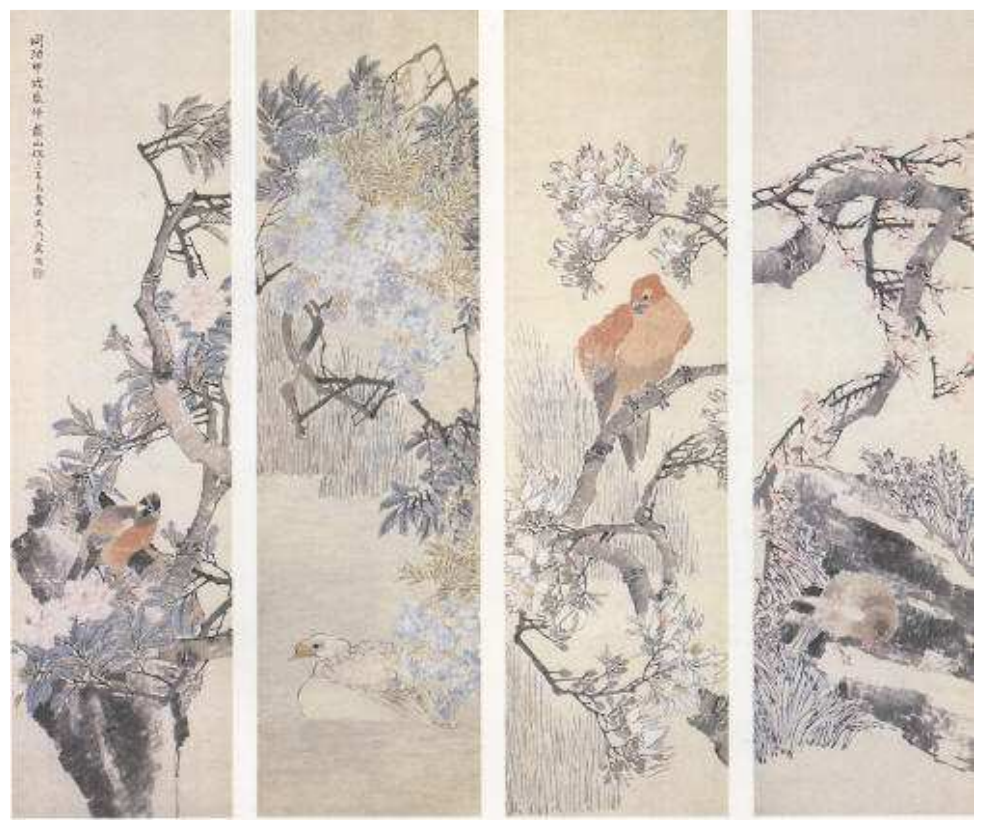

Ilustración 8. Pintura de Ren Xun (1835-1893)

$\mathrm{Ni}$ el formato, ni la manera de enfrentarse a una obra es igual para el artista oriental frente al occidental. No hay que olvidar que su caligrafía no se lee igual que la nuestra y por tanto, a la hora de dar importancia a las escenas o composiciones en una obra, la ubicación con respecto a la visión occidental, estará trastocada. Existen rollos pintados horizontalmente, en los que en concordancia con su lenguaje, narran las escenas de derecha a izquierda.

La caligrafía y la pintura van estrechamente ligadas la una a la otra, se han encontrado un gran número de obras pictóricas que poseen parte de caligrafía o texto en ellas. Esto se debe a que la poesía y la pintura van de la mano en el arte oriental.

- 'La pintura-poesía es la característica más peculiar de la pintura propiamente dicha del Extremo Oriente en comparación con la europea. (...) Los pintores de esta época son, primero, poetas y calígrafos y, después, pintores. En ellos se encuentra el origen de la pintura de letrados, cuya máxima manifestación culmina en la pintura de paisaje-poesía,66.

La tinta es muy utilizada a la hora de realizar obras pictóricas. El color negro será uno de los más utilizados, creando una pintura monocroma. A veces

\footnotetext{
${ }^{66} \mathrm{KIM}$, Sue-Hee. "El arte del Extremo Oriente”. Op.Cit. Pág. 30.
} 
aparece algún rasgo de color, pero no existen cambios bruscos, son aguadas de colores suaves y puros, creando composiciones elegantes, armónicas y de una belleza extraordinaria, conforme a la naturaleza representada.

- "La tinta, procedente de pasta de hollín vegetal, es negra y monocroma;(...) La pintura china, aunque comparada con la occidental resulte monocroma, está llena de matices cromáticos que evocan magistralmente el significado de los colores de la naturaleza. Rara vez utilizan el color directamente, pero cuando lo hacen se sirven de escasas pinceladas en rojo, azul y amarillo (los colores básicos) ${ }^{167}$.

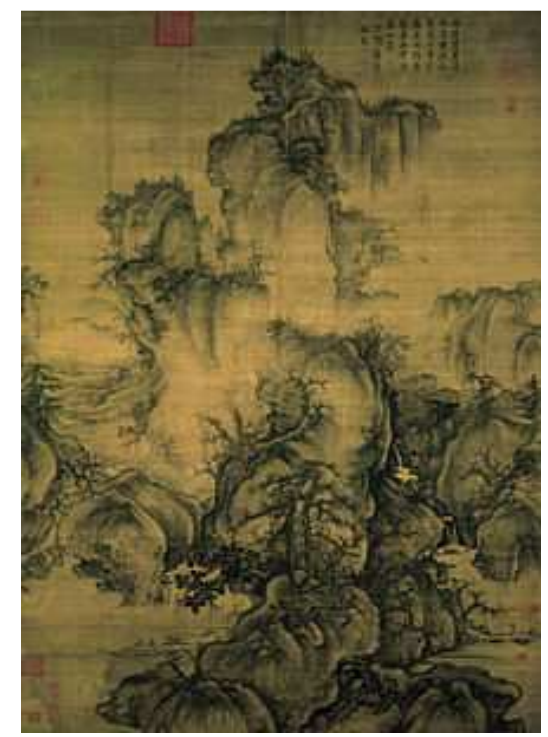

Ilustración 9. Guo Xi. Principios de la primavera, firmado y fechado en 1072. Colgante pergamino, tinta y color en $158.3 \times 108.1$ seda. Museo Nacional del Palacio, Taipei.

En el arte occidental no se valoran o catalogan a todas las artes por igual, la arquitectura, la pintura, la escultura, el dibujo... son las artes principales mientras que las lacas, los esmaltes, el vidrio... serían consideradas como "artes menores". En Oriente todas ellas presentan tal importancia en su elaboración, en su perfección y en su belleza que nos hace pensar que esa distinción tal y como la comprendemos nosotros, no existía. La arquitectura china no formaba parte de la categoría superior de arte, porque no se construían grandes edificaciones religiosas, debido a que el taoísmo y el confucionismo, no las necesitaban.

\footnotetext{
${ }^{67}$ GARCÍA- ORMAECHEA, Carmen. "Las claves del arte oriental”. Ed. Ariel, S.A. Barcelona, 1988. Pág. 51.
} 
- "El uso muy difundido e indebido de la estética y de la historia del arte occidental en la terminología, ha tenido como inmediata consecuencia que se abarque con el término de <<artes menores >> una serie de producciones artísticas que, en lo que respecta a China, está muy lejos, en efecto, de ser de interés secundario: las lacas, la orfebrería, la labor del vidrio, el tejido de la seda, etc., suponen una aportación muy importante en el estudio del gusto y de las técnica chinas,68.

El artista oriental, no posee ese afán de búsqueda e innovación, que en ocasiones rompe con los cánones establecidos por sus predecesores como ocurre en el arte occidental, no posee ese interés por marcar la diferencia y destacar. Allí se aprecian y se valoran las pinturas realizadas en otros tiempos, y se aprende mediante el estudio y la práctica de éstas. La copia en Occidente, se encuentra mal valorada, pero por el contrario en Oriente, es una técnica que se usa constantemente y por eso, es tan difícil catalogar las obras de arte en un periodo concreto.

La autoría tan importante para el artista de Occidente, carece de valor para el artista oriental. Actualmente, este concepto está variando, ya que se están realizando grandes exposiciones sobre arte oriental contemporáneo, en las que las obras van tomando un cariz influenciado por Occidente y la autoría se hace presente debido a que gran número de ellas se están llevando a cabo en países occidentales. Por tanto, se han visto influenciadas por otras culturas, debido a que el comisariado, el lugar expositivo y el espectador son occidentales. Debido a ello, es normal que las obras se nos presenten occidentalizadas.

De todos modos, no vamos a entrar en más detalle conforme al concepto de autoría Oriental-Occidental debido a que este concepto merecería por sí solo una tesis doctoral.

En la obra de la diseñadora Yang Liu podemos observar las diferencias que para ella, que nació en China y posteriormente se trasladó a Alemania, residen entre la cultura oriental y occidental. Los cuadrados de color azul, hacen mención a Occidente y los cuadros de color rojo, a Oriente.

\footnotetext{
${ }^{68}$ PISCHEL, Gina. "Breve historia del arte chino". Op. Cit. Pág. 114.
} 
Presentamos a continuación las más significativas (para un mayor estudio del tema, mirar anexo).

\section{Enfoque para resolver un problema}

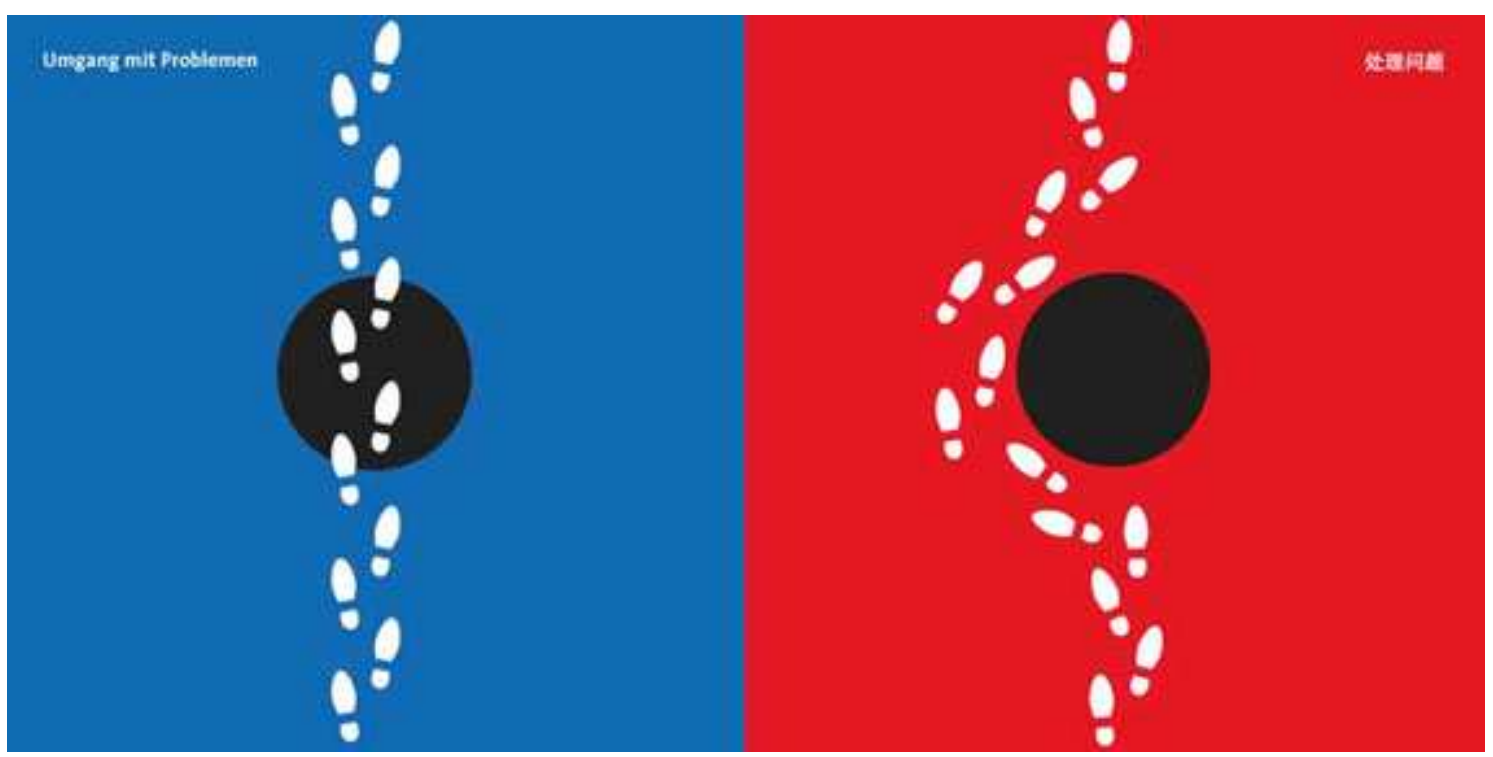

Ilustración 10. Diferencias cultura occidental y oriental.

\section{Contactos interpersonales}

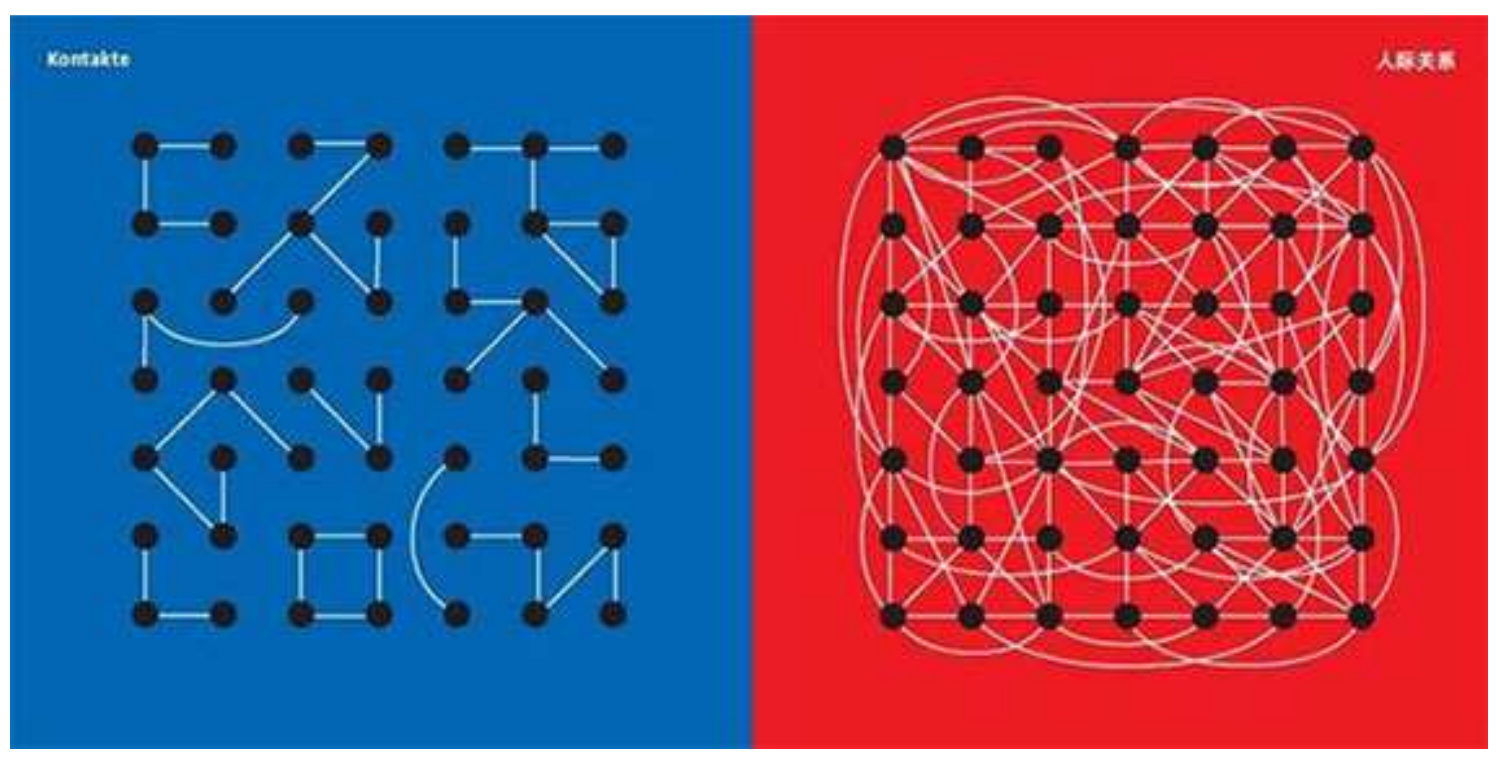

Ilustración 11. Diferencias cultura occidental y oriental. 


\section{Estilo de vida}

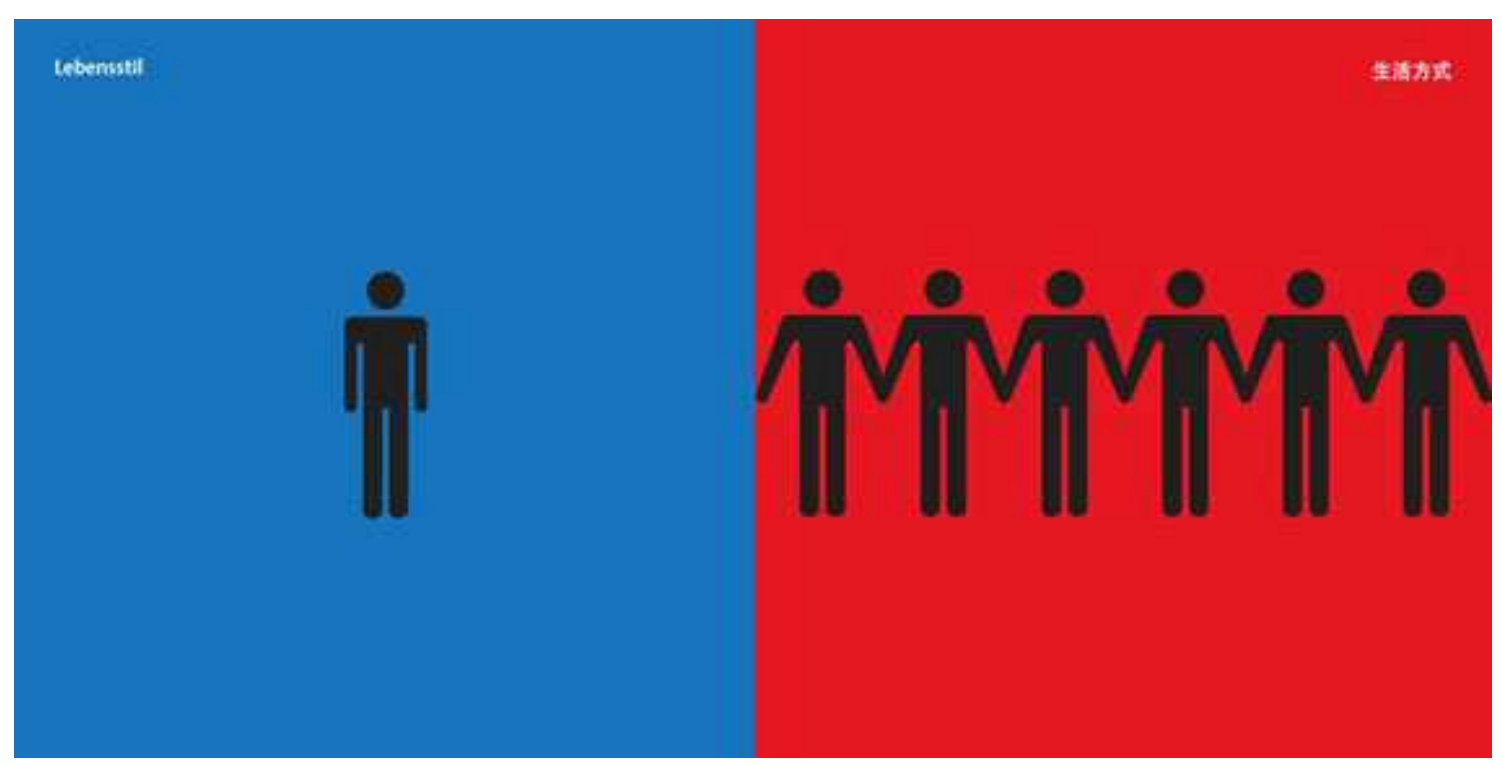

Ilustración 12. Diferencias cultura occidental y oriental.

\section{El Ego}

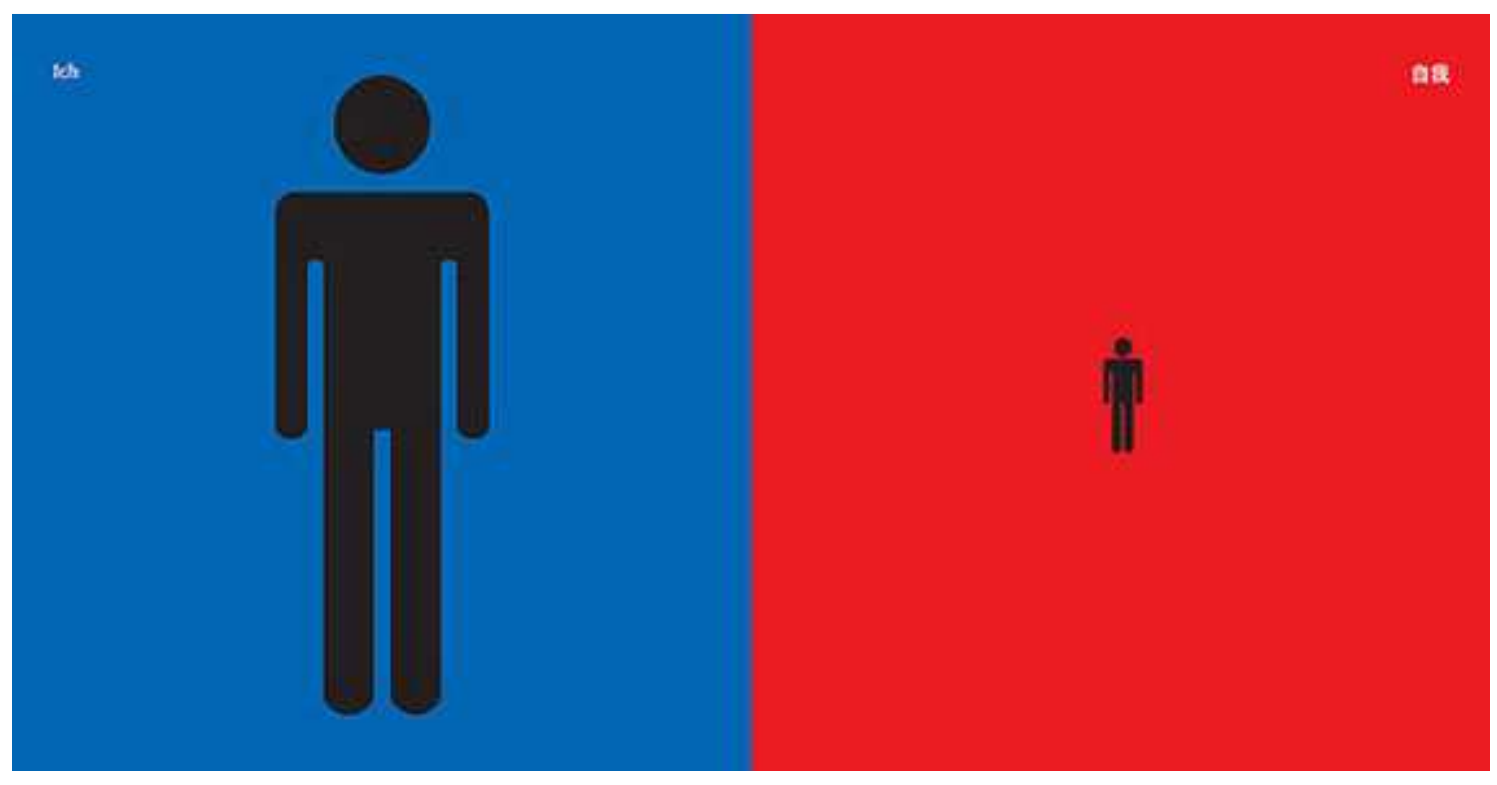

Ilustración 13. Diferencias cultura occidental y oriental. 


\section{Expresión de las opiniones}

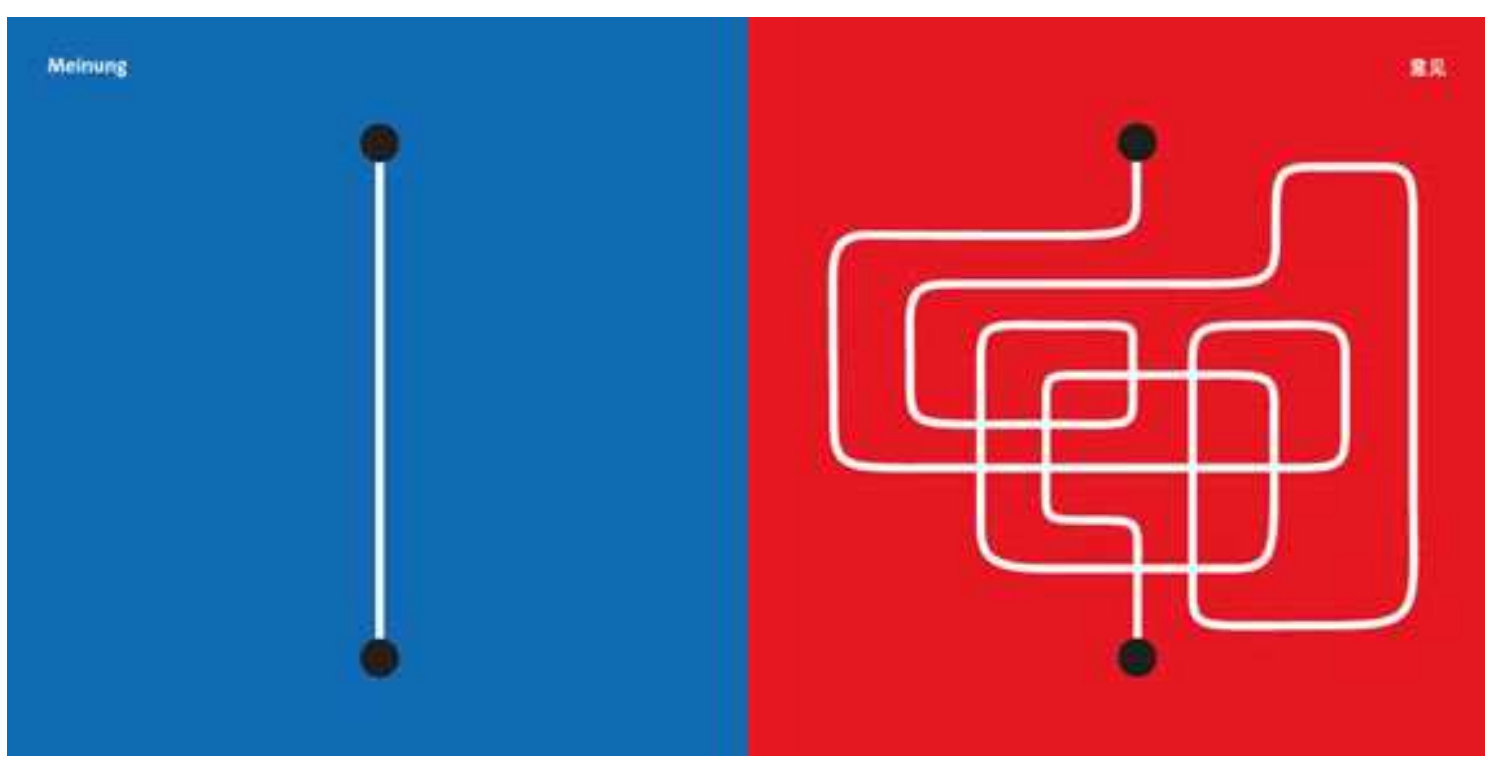

Ilustración 14. Diferencias cultura occidental y oriental.

\section{Reacción ante algo nuevo}

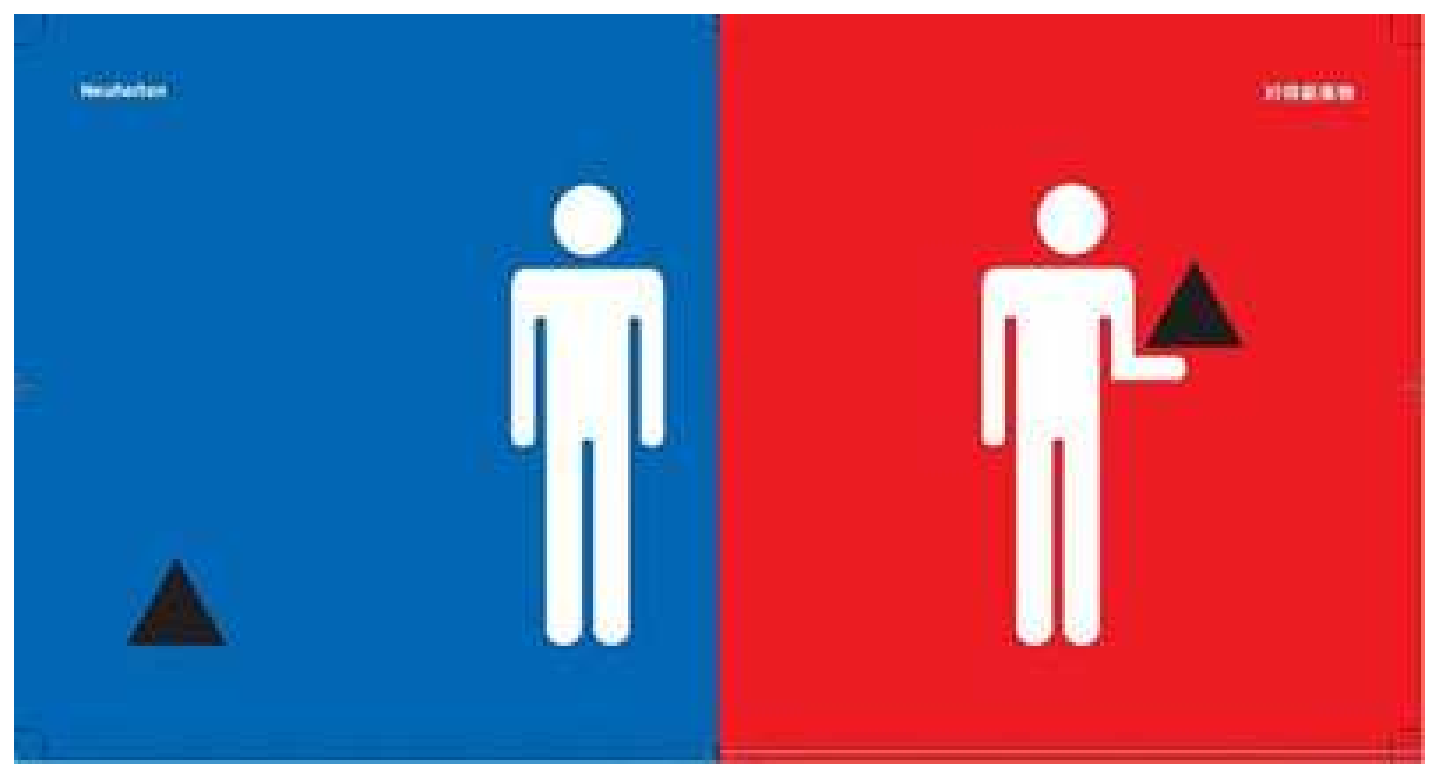

Ilustración 15. Diferencias cultura occidental y oriental. 
Las obras de los artistas contemporáneos orientales siguen poseyendo esa espiritualidad arraigada durante tantos años, y por eso, resultan tan atrayentes.

"Aunque los artistas de la China de hoy crezcan en un ambiente político todavía por alcanzar su plenitud democrática, su relación con el arte occidental es muy fuerte en términos de implantación de técnicas junto a la asimilación de sus tradiciones ancestrales. Esta fusión explica el dominio de lenguajes personales, que abarcan desde las críticas sociales hasta íntimas memorias personales, y que tanto ha impactado a la escena internacional, (...,, 69

Desde sus inicios el arte tiene un fin espiritual, místico o sagrado. Recordemos al hombre primitivo, y sus dibujos llenos de espiritualidad, convirtiendo al lugar donde se representaban en un lugar sagrado, en el que sólo unos pocos elegidos eran capaces de adentrarse. Con la evolución del hombre y todo lo que le rodeaba, el arte también fue evolucionando, pero no perdió ese carácter religioso, da igual que fuera destinado a un conjunto de divinidades de la naturaleza o a un solo Dios. Da igual que hablemos de una religión u otra, todas están unidas al arte.

A continuación desarrollaremos esta idea que une arte con religión, viendo cómo en el arte oriental (principalmente) acompaña al hombre en el camino de la vida y se convierte en su guía. También veremos cómo el artista occidental (principalmente) entiende el arte como proyección personal.

\footnotetext{
${ }^{69}$ CISCAR CASABÁN, Consuelo en VV.AA. "The Real Thing. Arte contemporáneo de China". Producción: Tate, 2008. IVAM Institut Valencià d’Art Modern. Valencia, 2008. Pág. 8. 


\subsection{Arte como camino}


Como hemos podido ver el arte nace con el Hombre, y nos acompañará hasta nuestra extinción. Sufre alteraciones de unas zonas del planeta a otras, por las diferencias culturales, políticas, pensamientos filosóficos, descubrimientos técnicos y científicos. La religión o función sagrada, entendida ésta como toda creencia o fe, tanto si va dirigida a un solo Dios o a diferentes divinidades también ha sido un factor importante en el arte desde sus inicios, aunque de manera progresiva se ha ido dando una separación entre ambas. En Occidente, este distanciamiento es mucho más notable ya que gran parte del arte que se hace actualmente nada tiene que ver con la religión.

Un ejemplo de ello podemos encontrarlo en Extremo Oriente.

- "Es importante también la creencia ancestral en el dios del cielo, Shang-Di, que otorga beneficios o que castiga a sus descendientes a través de fenómenos naturales (...). Los reyes y el pueblo ofrecían ceremonias y sacrificios a los espíritus de sus antepasados. Tanto las ceremonias litúrgicas como los objetos creados para éstas demuestran que el arte del Extremo Oriente se inició en relación con este culto" ${ }^{\prime 70}$.

- "El archipiélago japonés desarrolla su propia cultura a lo largo de la historia, aunque son innegables las huellas de las culturas china y coreana. Para comprender el arte japonés además de tener en cuenta su relación con el arte chino y coreano, hay que fijarse en unos elementos y características peculiares que lo relacionan con el sintoísmo, la religión autóctona, que rinde culto a los dioses de la naturaleza, lo cual es comparable a las creencias ancestrales chinas" ${ }^{\prime 11}$

Por tanto, el arte nos acompaña en el camino de la vida y en muchos casos, nos ayuda a liberar sentimientos, y nuestros momentos de alegría aumentan al contemplar una obra plástica o escuchar una bella melodía. En las grandes ocasiones, la música suele estar presente y la melodía escuchada pasa a formar parte de nuestra memoria, es un recuerdo unido a nuestras vivencias.

La música, para Confucio, era parte de la vida. Mediante ella, era capaz de conocer el estado de ánimo de una persona, podía transportarlo a lugares espirituales, influía en él y le expresaba sentimientos, formaba parte de sus recuerdos, mediante composiciones antiguas, aprendía la historia de sus ante-

\footnotetext{
${ }^{70} \mathrm{KIM}$, Sue-Hee. "El arte del Extremo Oriente". Op. Cit. Págs. 4 y 5.

${ }^{71} \mathrm{KIM}$, Sue-Hee. "El arte del Extremo Oriente". Op. Cit. Pág. 65. 
pasados... Por tanto, era un medio para conocer a los demás y también a sí mismo.

- “...) Kungtsé vive en la música, cómo la música significa para él una emoción de índole suprema, que revela, no solamente el sonido, sino también la personalidad moral de quien la produce ${ }^{\sharp 2}$.

- "Vemos como Kungtsé sabía con su música manifestar de tal manera su estado de ánimo, que un oyente ilustrado podía deducir su sentimiento"73.

En Occidente, solemos dar mayor importancia a las artes visuales que a las sonoras, convirtiendo a la escultura y la pintura como artes mayores frente a la poesía, la música, y también frente a otras artes como la orfebrería o los esmaltes. El cristianismo, se valió de la pintura y la escultura para mostrar de una manera visual sus enseñanzas y creencias al pueblo llano e iletrado. Por tanto, al igual que nuestros antepasados, hemos otorgado más valor a las artes visuales que al resto de artes que requieran la utilización de otros órganos sensoriales como puede ser la música o la poesía.

- "Aunque "arte" es un término que abarca todas las bellas artes (poesía y música tanto como arquitectura, pintura, dibujo y escultura), los aspectos plásticos del arte son los que afectan más directamente nuestra vida, puesto que están siempre en torno a nosotros y forman parte de nuestro medio. La música y la poesía son artes privadas a las que su público necesita aproximarse de manera deliberada. No están físicamente presentes como objetos, sino que deben trabajar invisiblemente en nuestra sensibilidad"74.

- $\quad$ "Históricamente las artes plásticas tienen también una cierta prioridad. La escultura y la pintura prehistóricas continúan siendo una realidad visual y no conocemos otras artes de tal antigüedad" ${ }^{\prime 75}$.

El arte medieval, no sólo se dedicó a enseñar la religión, fue más allá, todo en la vida estaba relacionado con lo sagrado, con lo celestial. Una espiritualidad que con el paso de los siglos va desapareciendo hasta llegar a la creación de obras sacras sin espíritu ni devoción. Imágenes creadas por necesidad, pero sin misterio ni religiosidad. La sociedad occidental se deja llevar por la psicología, la ciencia y la tecnología y esto lleva a un arte más experimental,

\footnotetext{
${ }^{72}$ WILHELM, Richard. "Confucio". Op. Cit. Pág. 18.

${ }^{73}$ WILHELM, Richard. "Confucio". Op. Cit. Pág. 26

${ }^{74}$ READ, Herbert en VV.AA. "Las Bellas Artes. Orígenes del Arte Occidental". Enciclopedia ilustrada de pintura, dibujo y escultura. Grolier Incorporated. New York, London...1969. Pág. 5.

${ }^{75}$ READ, Herbert en VV.AA. "Las Bellas Artes. Orígenes del Arte Occidental". Op. Cit. Pág. 5.
} 
basado en geometría, formas abstractas, interpretación de sueños, representación de miedos...

- “(..) la belleza nunca fue una aspiración del pintor cristiano. El pinta lo que $<<c r e e>>$, y será a través de su creencia que podrá acercarse a la belleza- a la belleza tal como él la entiende: a Dios"76.

- "El artista del Renacimiento quiere, ergo sabe, dibujar- pintar- las cosas del natural: las <<copia>>. El artista occidental, desde el siglo XV al XIX, <<copia>>. Ya no pinta lo que $<<$ crees> porque la esfera de la creencia ha quedado divorciada del arte. Pinta lo que $<<v e>>" 77$.

Cada etapa del arte occidental intenta diferenciarse de la técnica, de la estética y del canon de su predecesora, no es un camino lineal como en Oriente, es un camino entrecortado en el que cada periodo artístico tiene un principio y un final más o menos delimitado. Aunque exista algún tipo de retroceso o mirada hacía períodos artísticos antiguos por parte de los artistas de otras épocas, sólo se rescatará algún pequeño rasgo, pero no habrá un retroceso concreto. En parte, porque la época en que se vivió ese arte ya no existe para nosotros, ese momento concreto con un sinfín de necesidades sociales, políticas y filosóficas concretas, ha variado de unos siglos a otros. El arte de entonces, ya nada tiene que ver con las necesidades y la búsqueda que promueve el arte de la época sucesora.

En Oriente, la copia, no posee la misma calificación que en Occidente, pues en estos países, los artistas en su proceso de aprendizaje deben de realizar la copia de antiguas obras de grandes maestros para aprender las técnicas de otros tiempos y además revivir esa espiritualidad, esa manera de abordar esa composición que poseían ellos. Por tanto, no existe una ruptura con el pasado, existe una línea continua que avanza en un doble sentido y que se amplía con el paso del tiempo, creando un camino de conexión entre el pasado y el presente artístico. Además todas las creencias y filosofías que giran en torno a estos países tienen un fin común, con lo cual no existe una variación tan grande de unos siglos a otros. Lo que implica que el arte antiguo, si forme parte y participe del nuevo.

\footnotetext{
${ }^{76}$ FUSTER, Joan. "El descrédito de la relidad". Facultad de Bellas Artes de la Universidad Politécnica de Valencia. Valencia, 1999. Pág. 33.

${ }^{77}$ FUSTER, Joan. "El descrédito de la relidad". Op. Cit. Pág. 35. 
En realidad el arte como camino está más unido al mundo oriental debido al tipo de filosofía que se da en esos países. Da igual que sea en India, China, Japón o Corea, el fin espiritual es llegar a la unificación, ser parte de un Todo. Vivir en un periodo atemporal donde no exista el pasado ni el futuro y fundirnos en un continuo presente. Para ello, hay que vivir conforme el "Tao" (China) o el "Do" (Japón) que es el camino para alcanzar ese estado de "vida eterna" o "paraíso celestial". Retomamos las filosofías orientales estudiadas en el primer capítulo de la tesis, para tratar el arte como el camino hacía el ser y la unidad con Todo. El arte es un medio como podría ser la escritura, la lectura, etc. para alcanzar ese punto de conexión y esto se consigue con cualquier acción que nos ayude a centrarnos tanto en nuestra labor que nos haga olvidarnos del tiempo, del espacio, que deje a un lado nuestros pensamientos y nos haga fundirnos con la obra que se está realizando. No basta con dar pinceladas, tallar o esmaltar, deben de poner su "alma" en cada hacer, en cada detalle, ser parte de lo representado y unificarse con él.

- "La pintura china constituye un mundo propio, vivido e imposible de repetir, cuyo lenguaje alcanza una íntima expresión de vida. (...), la obra pictórica china nos habla un lenguaje más universal, más fácil y más evidente: nos convierte en partícipes de un instante de vida que destruye las distancias en el tiempo y en el espacio",78.

Esto se consigue mediante la contemplación de lo que se quiera representar, entrando en contacto con él; pasear por ese espacio, oler las flores, escuchar o acariciar los animales, observar los rostros... Pero el artista, para llegar a ese tipo de fusión con la obra debe de llevar una vida según el "Tao", no lo conseguirá si se aleja de él.

Esto ayuda a que cada pincelada sea firme y determinada, pues no existen las dudas.

- " “...) el vitalismo y el movimiento que reflejan la personalidad y el pensamiento del artista son primordiales para mostrar el carácter de la persona retratada; el estado espiritual del pintor es básico en la captación y la plasmación de la realidad psíquica de su modelo",79.

\footnotetext{
${ }^{78}$ PISCHEL, Gina. "Breve historia del arte chino". Op. Cit .Pág. 56.

${ }^{79}$ Xie He, nombrado por KIM, Sue-Hee. “El arte del Extremo Oriente”. Op.Cit. Págs. 22 y 23.
} 
Algunos artistas meditan o hacen yoga, antes de abordar la obra. Esto les conecta con el universo, es el caso de la India.

- "Lógicamente, el artista debe adecuar su espíritu a través del yoga antes de lanzarse a tan compleja tarea,80.

- "(...) por su propio ritmo respiratorio, el yogîn repite y en cierto modo revive el Gran Tiempo cósmico, las creaciones y las destrucciones periódicas del universo',81.

- "Todo ejercicio de concentración o de meditación yoga <<aísla>> a quien la práctica, le sustrae el flujo de la vida psico - mental y, por consiguiente, disminuye la presión del tiempo,82

Todo lo nombrado anteriormente, nos lleva a la mentalidad oriental y al tipo de filosofía que se establece en estos países; budismo, lamaísmo, taoísmo, confucionismo, zentrismo... estas doctrinas o enseñanzas, aunque distintas entre ellas, promueven la paz, el bienestar, el respeto, la meditación, el conocerse a sí mismo... todas buscan seguir el camino correcto en la fase terrenal, para alcanzar un mayor esplendor espiritual, ya sea mediante la reencarnación, mediante la "vida eterna", el vacío, la vida celestial... es un camino en el que las enseñanzas antiguas siguen vigentes con el paso de los siglos, ganando importancia unas u otras, dependiendo del periodo, la dinastía o las influencias en un momento dado, que se dan entre unos países de Oriente a otros.

El cristianismo en sus orígenes, también sirvió en Occidente como guía para los hombres en nuestra vida terrenal, para conseguir con nuestras buenas acciones no salirnos del camino correcto y alcanzar la vida eterna después de la muerte y ascender al reino de los cielos. Esta visión como hemos visto, se mantiene en el arte medieval, pero se va perdiendo con el paso del tiempo.

- “(..) para el hombre cristiano anterior al Renacimiento, no era sólo la realidad que le entraba por los sentidos: veía, percibía en ella, además, de una manera clara, el peso de un parentesco supremo, la mano creadora que encauzaba todo hacia un fin exterior a él,83.

\footnotetext{
${ }^{80}$ GARCÍA- ORMAECHEA, Carmen. "Las claves del arte oriental". Op.Cit. Pág. 27.

${ }^{81}$ Mircea Eliade. "Imágenes y Símbolos". Op.Cit. Págs. 93 y 94.

${ }^{82}$ Mircea Eliade. "Imágenes y Símbolos". Op. Cit. Pág. 95.

${ }^{83}$ FUSTER, Joan. "El descrédito de la relidad". Op. Cit. Págs. 42 y 43. 
- "Es también significativo que el testimonio artístico de los primeros cristianos que confiaban en una vida futura mejor se revelara en la decoración de tumbas, prueba de que su principal interés no estaba en ese mundo, sino en el futuro,84.

El confucionismo al igual que sus enseñanzas, realizaba un arte más realista, austero, sobrio y frío frente a la candidez, dulzura, sutileza y poética del taoísmo. El budismo por su parte, recurre a la creación de templos, monasterios, santuarios, estupas y estatuas de buda y bodhisattva. Con el lamaísmo se crean principalmente templos y esculturas sacras. Lo más destacado de la filosofía zen, quizá sea sus jardines, creados en el exterior o interior de las edificaciones como espacios ocultos y sagrados que otorgan paz y bienestar a quien los contempla e incitan a la meditación, son recreaciones de la naturaleza y nos conectan con el universo.

Por tanto, la temática principal en todas las épocas es la naturaleza, una naturaleza en la que el hombre al igual que el resto de seres vivos forma parte de ella, no existe el antropocentrismo, no somos más que una hormiga, que una planta, que el viento... una naturaleza que se representa en su mayoría, en tinta negra y pinturas monocromas que reflejan a la perfección los paisajes con o sin fenómenos atmosféricos. La figura del hombre carece de importancia frente al paisaje, aunque la figura humana, aparece en algunas escenas de costumbres tradicionales o temas relacionados con la historia, retratos, etc.

- "(...) pintura, sobre todo la de paisaje de las épocas Tang y Sung, que representa el más atractivo a veces incluso mágico vértice del arte chino, tiene sus complejas particularidades. Escapa a esas categorías de imitación de la realidad de representaciones naturalistas y de visión lírica en las que se ha desarrollado la pintura occidental de paisaje. Es un mensaje evocador, altamente subjetivo, hecho de una amplia e íntima compenetración contemplativa en los fenómenos y ritmos de la naturaleza, pero de sensible y esencializada estilización de formas, donde el vacío, la omisión, la eliminación de detalles adquieren tanta fuerza sugestiva como lo representado. Es arte que tiende, incluso mediante el vacío y la ausencia, a expresar lo visible y sugerir lo invisible, firme en el principio tradicional del $<<i$ tao pi pu tao>>: <<presente la idea, el pincel puede ahorrarme la ejecución>>; y es arte que, confiado esencialmente en los valores colorísticos de la tinta, es esencialmente caligrafía, 85

En el arte oriental, todavía existe esa conexión con la naturaleza que el mundo occidental ha ido perdiendo conforme nos hemos ido alejando de ella.

\footnotetext{
${ }^{84}$ BOVINI, Giuseppe en VV.AA. "Las Bellas Artes. Orígenes del Arte Occidental". Op. Cit. Pág. 39.

${ }^{85}$ PISCHEL, Gina. "Breve historia del arte chino". Op. Cit. Págs. 7 Y 8.
} 
Perduran las tradiciones ancestrales, el respeto y el estudio por las artes y libros antiguos, se mantienen las enseñanzas de maestros ya fallecidos en cuanto que se crean religiones posteriores a su fallecimiento basadas en ellos.

- "Confucio no fue sino un filósofo más (...). Sin embargo, de él se desarrolló el confucionismo, que durante dos milenios imperó en China, hasta que en el año 1912 se puso término a su poderío político". 86

- $\quad$ "En toda aquella evolución la persona de Confucio desempeñó un papel destacado. Siempre la mirada estuvo fija en él como la única excelsa autoridad. (...) Ante su tumba se ofrendaba, aún, con las formas del culto de los antepasados. Más tarde se erigió un templo. (...). Luego, a Confucio se le erigieron templos en todo el imperio chino. A principios del siglo XX, fue proclamado dios. Es, pues, una evolución digna de memoria que Confucio, que no quiso ser sino un hombre más, sabiendo que ni siquiera era un santo, acabó por ser dios". ${ }^{87}$

Es un arte basado en los cinco elementos (agua, fuego, tierra, aire y metal), que representa la naturaleza; paisaje, flores, animales, hombres... El artista no busca la autoría de la obra plástica, en muchos casos y debido a la copia de estilos anteriores, no es fácil ni siquiera su catalogación. Sólo buscan mostrar un paisaje o contar una historia desde su espiritualidad.

- $\quad$ "El arte chino surge, principal e indiscutiblemente, del rito y de una mitología de la fundación del país basada en la teoría de la creación de los cinco elementos del universo. La esencia del arte chino se refleja en los objetos de bronce y en las inscripciones de la dinastía Shang, en las pinturas murales de las tumbas de los Han y en las esculturas y pinturas de las dinastías posteriores, ${ }^{, 88}$.

Al intentar describir la estética taoísta Carmen García-Ormaechea escribe:

- "A lo largo de todos los tratados chinos aparecen claramente definidos seis principios que, aunque reciben títulos distintos, tratan de:

1. Espíritu. La captación del alma de la naturaleza, que se adentra en la realidad esencial huyendo de la mera ilusión óptica. Se debe tener siempre presente que el paisaje es un trozo de Tao, y que una sola pincelada contiene en sí misma el universo. (...)

2. Empatía. El objetivo de la pintura china es la transmisión poética al espectador. Para ello, el artista precisa de una gran capacidad de sugestión, y el espectador de una absoluta concentración y devoción, (...)

\footnotetext{
${ }^{86}$ JASPER, Karl. "Los grandes maestros espirituales de Oriente y Occidente". Op. Cit. Pág. 67.

${ }^{87}$ JASPER, Karl. "Los grandes maestros espirituales de Oriente y Occidente". Op. Cit. Pág. 71

${ }^{88} \mathrm{KIM}$, Sue-Hee. "El arte del Extremo Oriente". Op. Cit. Pág. 7.
} 
3. Composición. El artista debe tener una idea global y genérica del tema y una prolongada meditación sobre cada elemento antes de agruparlos armónicamente en la contemplación. (...)

4. Comunión con la naturaleza. (...). Supone la íntima comunión del artista con el paisaje que quiere representar, en el que debe integrarse a fuerza de tratarlo, viviéndolo o paseándolo: (...)

5. Pincel. No se trata de sustancia ni de forma; es un movimiento, un vuelo, trasciende los aspectos meramente técnicos, de tipos de pinceladas, etc., para evidenciar la recreación en el proceso más que la obra <<terminada>>. La soltura necesaria se debe adquirir copiando a los clásicos, (...)

6. Tinta. (...) debe ofrecer variaciones de gradación a fin de producir una sensación de localización y profundidad de los objetos, formando de esta suerte una pauta natural. (...), 89 .

En Oriente, todas las artes poseen un papel relevante, desde el esmalte y las lacas, hasta la pintura en seda o la escultura. Existen diferencias notables, pero no una clasificación que marque una línea abismal entre ellas, y se agrupan según las necesidades de las distintas épocas. Así, podemos encontrar las pinturas con poemas, espejos, pinturas en seda, porcelana, diversos trabajos en jade... Los artistas en ocasiones no eran expertos en pintura o escultura, sino letrados que realizaban pinturas caligráficas, de gran composición y belleza. Según el periodo histórico los pintores y escultores eran catalogados como artesanos o tallistas.

- "La pintura propiamente dicha, es decir, la pintura-poesía (caligrafía) es obra de los pintores-poetas. Su tema preferido es el paisaje de modo que practicaban el género de San Shuihua, es decir, la pintura de montañas y de agua,

En el arte coreano; "La pintura de letrados siguió su desarrollo y difusión entre poetas y eruditos confucionistas con altos cargos en la administración. Sus temas preferidos eran el bambú y la rama florida del ciruelo, junto con la poesía caligrafiada, ${ }^{, 01}$.

Como acabamos de comentar, las obras reflejaban paisajes hermosos, las diversas costumbres del país, flores o animales, todas ellas estaban, cargadas de espiritualidad, de calma. El artista, antes de abordar la pintura, tenía una labor de contemplación, después ponía la máxima atención en su realización y volcaba su anhelo y afán por expresar lo que ese paisaje inspiraba pero

\footnotetext{
${ }^{89}$ GARCÍA- ORMAECHEA, Carmen. "Las claves del arte oriental”. Op. Cit. Págs. 52,53 y 54.

${ }^{90} \mathrm{KIM}$, Sue-Hee. "El arte del Extremo Oriente". Op. Cit. Pág. 30.

${ }^{91} \mathrm{KIM}$, Sue-Hee. "El arte del Extremo Oriente". Op. Cit Pág. 63.
} 
no con cualquier técnica, sino con la aprendida de los grandes artistas del pasado. Con su obra, nos está relatando, nos está enseñando una realidad. En muchas ocasiones ayudado como hemos visto, por las palabras.

- El pintor chino deduce, por tanto, de la observación de la realidad una imagen que suscita en su espíritu una íntima y poética vibración; pero ésta se concreta, por encima de un fiel realismo, en una fantasía poética que encuentra su consistencia más en la armonía universal de las cosas que en la continuidad de lo real. (...). El hecho de que se intensificara entonces la necesidad de añadir a las obras pictóricas largas leyendas puede ser explicado precisamente por los caracteres evocadores de la pintura china de paisaje. Los chinos debieron encontrar en la palabra, de por si abstracta, y en la escritura ideográfica, de por sí elegante, una ayuda eficaz para una más amplia penetración de la obra pictórica. (...). Nace así, un curioso punto de encuentro, desconocido en los demás países pero muy de acuerdo con la mentalidad china: la poesía o el comento literario hablan al espectador de lo que ve representado figurativamente; y recíprocamente, lo figurativamente representado se realza al concretar un sentido poético más universal",92

Las grandes obras arquitectónicas sagradas orientales no se realizan durante la aplicación del confucionismo y el taoísmo, ya que no existe un Dios o ser único en el que se basen sus creencias. El templo y el santuario, se erguirá por el budismo con grandes imágenes de Buda.

- "...) ni el confucionismo ni el taoísmo presentan dioses a quienes dedicar templos, ni postulan religiones que congreguen a los fieles a la oración, por lo que tenemos que renunciar a la gran arquitectura sacra, 93

El arte también está presente en las construcciones funerarias como un vínculo entre el difunto y el más allá. En el interior de las tumbas, al principio, eran seres humanos y animales vivos los que acompañaban al difunto, después fueron sustituidos por cerámicas que representaban a la perfección toda la compañía que quería llevarse o necesitaría en su viaje después de la muerte. También se incorporaron joyas, sedas, espejos... objetos que podría necesitar el difunto en su paso al mundo celestial.

- “(...) erradicaron los sacrificios funerarios, al dar el gran salto ético de <<engañar >> a los dioses sustituyendo los seres vivos por estatuas de cerámica u otros materiales. Este último hecho tienen una gran incidencia artística porque desarrolla el ajuar funerario, que es una de las manifestaciones más importantes de China, pues supone una fuente inagotable de obras de arte con un gran valor documental, ${ }^{\text {,94. }}$.

\footnotetext{
${ }^{92}$ PISCHEL, Gina. "Breve historia del arte chino". Op. Cit. Pág. 91.

${ }^{93}$ GARCÍA- ORMAECHEA, Carmen. "Las claves del arte oriental”. Op. Cit. Pág. 42.
} 
También se han encontrado objetos funerarios en tumbas más sencillas para honrar y comunicarse con sus antepasados.

- "El arte está presente en los numerosos objetos encontrados en los yacimientos funerarios del río Amarillo. Los ritos funerarios estaban dedicados a los antepasados, quienes aseguraban el orden social y la armonía del universo. La comunicación con los espíritus dio lugar a un lenguaje mágicorreligioso del que fueron derivando los primeros caracteres escritos, pictográficos, que representaban ya desde su origen aspectos tanto concretos como abstractos" ${ }^{\prime \prime 5}$.

Por tanto, la religión o creencia espiritual y sagrada ha marcado el arte de cada periodo tanto en Occidente como en Oriente. Esto se debe a que al igual que el arte nace y convive con el hombre, las creencias mágicas y religiosas, también nacen y perduran a lo largo de su existencia.

Como ya comprobamos en el capítulo anterior, aunque actualmente el arte profano o la visión no sacra del mundo en Occidente está muy presente, no puede dejar de lado sus raíces, fiestas, ni creencias provenientes de un pasado religioso. Por tanto, este arte rompedor, provocativo, a veces insultante, en ocasiones alejado de la belleza que se viene realizando en el siglo XX, sigue poseyendo en su esencia un cariz espiritual y mágico.

${ }^{94}$ GARCÍA- ORMAECHEA, Carmen. "Las claves del arte oriental”. Op. Cit. Pág. 37.

${ }^{95}$ GARCÍA- ORMAECHEA, Carmen. "Las claves del arte oriental”. Op. Cit. Pág. 33. 

3.2. Arte como proyección personal 
Como hemos comprobado en el arte oriental, el artista no posee la necesidad de destacar, de ser conocido, de ser original, de que lo valoren los demás. Para él, eso no es importante porque si se deja llevar o caer en la trampa del ego, estará alejándose del camino correcto. Lo importante no es lo que se encuentra en la visión racional, en cuanto que ésta deriva en rencores, odios, egoísmos, miedos, insatisfacciones... y todo ello bloquea nuestro ser, nuestro momento presente

En el mundo occidental, nos dejamos llevar y valoramos en suma el raciocinio, esto nos hace vivir en el pasado, volvemos a él una y otra vez, pero también nos hace pensar en el futuro y que pasemos parte de nuestro tiempo proyectando ideas y actos para tiempos venideros. Esto demuestra que en contra de la intención del pensamiento oriental de alcanzar y vivir en un presente continuo, en Occidente el presente es el gran olvidado. Nos cuesta centrarnos y valorar lo que tenemos en el momento actual, nuestra mente siempre está yendo y viniendo en un camino de ida y vuelta, por eso nos cuesta encontrar la felicidad tan ansiada por el ser humano.

- "Acudir al pasado para explicar el presente trae aparejados otros problemas inherentes; la memoria es notablemente defectuosa, tanto a causa del paso del tiempo como de los filtros que pasaron nuestras primeras percepciones, percibidas por un cerebro todavía incapaz de tener pensamientos reflexivos y abstractos ${ }^{, 96}$.

Por lo que es erróneo buscar en esos recuerdos las explicaciones o justificaciones de lo que nos ocurre en el presente.

Esto no quiere decir que en Oriente no echen la vista atrás, porque como hemos podido comprobar sus enseñanzas y su arte se basan en libros antiguos y maestros de otras épocas, pero no lo hacen desde la misma perspectiva.

La vanidad, el egoísmo, el afán por destacar, la búsqueda del triunfo, todas ellas son invenciones "modernas", se dan en mayor medida en la cultura de Occidente, en cuanto que nos movemos en un ambiente competitivo donde desde pequeños se nos enseña la rivalidad, nos educan para triunfar y destacar, haciendo que nos sintamos fracasados y decepcionados si no conseguimos nuestros objetivos. En Oriente las enseñanzas les separan de

\footnotetext{
${ }^{96}$ HAMILTON, Elizabeth. "Desentrena a tu loro. La mente y el camino del Zen". Editorial Edaf, S.I. Madrid, 2010. Pág.128.
} 
esta búsqueda, aunque claro está, no se encuentran cien por cien exenta de ella.

- $\quad$ "Las personas se consumen en pos de cosas: la longevidad, la fama, la posición social y la riqueza. Sin embargo, no saben que estas cuatro cosas sólo traen problemas $y$ ansiedad,97.

- 'Son las personas que pueden ver más allá de las quimeras de la longevidad, la fama, la posición social y la riqueza las que no se ven sobrecargadas por la ansiedad y el miedo. (...). Si no codicias la longevidad, no tienes miedo de morir. Si no te preocupas por la fama, te dará igual cómo te presentas ante los demás. Si no estás interesado por la posición social, no te preocupará lo que otras personas piensen de ti. Si no eres posesivo con el dinero, no agotarás tu mente y tú cuerpo para acumularlo. No tendrás necesidad de envidiar a los demás y podrás seguir tus propios principios y ser fiel a ti mismo,98

- "Por supuesto, no se puede disfrutar de la vida si no se tiene algo de riqueza o longevidad. Sin embargo, forzarte hasta el agotamiento para seguir estas metas y no saber dónde detenerse es robarte a ti mismo el tiempo que tienes en este mundo, 99 .

No hay que olvidar que los grandes maestros orientales, no eran personas que vivieron rodeadas de lujos, proyectando en los demás su superioridad ni su grandeza. Por el contrario, eran personas cercanas que decidieron dar a conocer lo que ellos entendían como el camino a seguir para alcanzar la paz, el bienestar, la felicidad. Podríamos decir que encontraron la piedra filosofal que tanto anhelaban los alquimistas, el "paraíso celestial".

Esta idea de hacer, sin destacar, podemos encontrarla en el arte. La copia de obras antiguas como hemos comprobado anteriormente, en ocasiones impedía la datación de éstas, porque no se podían diferenciar con claridad del original puesto que, no poseían signos distintivos que delataran la autoría del artista.

En Occidente, en el arte románico, algunos autores, ya dejaban impreso un signo o un dibujo que hiciera reconocible la "autoría" del artista.

\footnotetext{
${ }^{97}$ WONG, Eva. "LIE TSE. Una guía taoísta sobre el arte de vivir". Editorial Edaf. Madrid. 2012. Pág. 278.

${ }^{98}$ WONG, Eva. "LIE TSE. Una guía taoísta sobre el arte de vivir". Op. Cit. Pág. 278

${ }^{99}$ WONG, Eva. "LIE TSE. Una guía taoísta sobre el arte de vivir". Op. Cit. Pág. 280.
} 
- "Nuestro conocimiento de los artistas y artesanos a quienes debemos las pinturas murales y los manuscritos es muy limitado. En ocasiones hay documentos que los mencionan y algunas veces, pero sólo en muy raros casos, el pintor firma un manuscrito o incluso añade un esquemático autorretrato indicando una conciencia hasta entonces desconocida de la importancia del artista. Muchos copistas de libros y sus ilustraciones eran monjes" ${ }^{\text {"100 }}$.

A partir de este momento y hasta nuestros días, la búsqueda por un reconocimiento por parte del artista, ha ido en aumento, y cada vez se le ha ido otorgando una mayor importancia a la autoría de la obra que al objeto creado.

El espectador deja de ver las representaciones para centrarse en la persona que las realiza y cuanto más renombre tiene el artista, más alabadas y veneradas serán sus obras (y por tanto aumentará su cotización, su valor comercial), sin importar lo que éstas nos transmitan. Esto se debe a que el ser de Occidente, basa su vida, en el status social. Esto marca la diferencia, ya no nos dejamos llevar por nuestros sentimientos ni nuestros instintos, nos dejamos llevar por todo aquello que creemos va a hacer mejorar nuestra posición en la sociedad, nos va a hacer superiores ante nuestros iguales El ego está presente en todas las facetas de nuestra vida y eso nos ciega ante la realidad.

De ahí que se quiera romper con todo lo establecido pero siempre acorde con las necesidades del momento, porque debemos innovar, ser los mejores, conseguir logros, descartar lo antiguo, para ser nosotros los inventores del nuevo arte. Esto naturalmente nos lleva a decepciones, y si nadamos a contracorriente, nos puede llevar a la desesperación. Ejemplo de ello pueden ser las obras que en ciertos periodos surgieron y que no fueron bien valoradas por la sociedad en su momento, y años o siglos después, se ha considerado a sus creadores como los propulsores de nuevas tendencias actualmente muy bien valoradas. Han pasado de no vender su arte y vivir prácticamente en la miseria toda su vida, a entrar a formar parte del elenco de grandes artistas y que sus obras formen parte de grandes colecciones pictóricas, adquiridas a unos precios descomunales.

La cuestión es quiénes son los encargados, y con qué juicio o baremo se valora a unos artistas o a otros. Por qué el espectador se ve coaccionado por

\footnotetext{
${ }^{100}$ ZARNECKI, G. en VV.AA. "Las Bellas Artes. Orígenes del Arte Occidental". Op. Cit. Pág.115. 
las galerías a tener en mayor estima unas obras o unos artistas que otros, cuando sus intereses son económicos.

- $\quad$ "El tema auténtico es tabú. Circula una jovial literatura entorno a las exposiciones, y nunca se sabe-- ¿hay la posibilidad de saberlo?-qué pintor es <<mejor>> que el siguiente"101.

Actualmente, el arte tanto de Occidente como de Oriente, se ven influenciados el uno por el otro. El arte oriental se ha abierto al mundo, y la autoría está presente en todas sus obras, los artistas buscan ese reconocimiento occidental y aunque conservan la esencia de sus países, la temática y la técnica de realización, se ha visto alterada y modernizada. El arte se está convirtiendo en una industria artística.

- "Si primero fue la economía el motor que movió y propició el cambio, (...), ahora le toca a la cultura manifestar toda su fuerza. $Y$ es que el reciente desarrollo económico de China está teniendo su paralelismo en el ámbito de la cultura. El arte, como uno de los exponentes más destacados de la industria cultural, ha abandonado las consignas para incorporar nuevos temas, anteriormente censurados, aumentando su reconocimiento y repercusión internacional" ${ }^{\prime 102}$.

Esto nos lleva a que muchos artistas sean del país que sean, caigan en la producción y reproducción de obras con el único fin de sacar beneficio económico de ellas, sin prestar apenas atención a lo que representan. Se convierte en un arte vendible, pero sin corazón. Muy lejos de las <<creencia>> del arte medieval, y la contemplación y estudio del arte oriental hasta hace relativamente poco tiempo.

- "Con la creciente comercialización del mercado del arte y la rápida subida de precios, gracias a la cual determinados artistas se han enriquecido hasta niveles increíbles, se ha producido una consiguiente tentación para muchos artistas de seguir creando un arte que sea vendible ante todo, en lugar de interesante, desde el punto de vista creativo"103.

Las galerías de arte se han convertido en "tiendas" donde exponer la mercancía, y se piensa en las ganancias a la hora de escoger la obra de unos artistas $u$ otros, no se valora en sí el objeto ni quien lo realiza, sino su proyección en el mercado del arte. Lejos queda esa visión anónima del artista,

\footnotetext{
${ }^{101}$ FUSTER, Joan. "El descrédito de la relidad". Op. Cit. Pág. 175.

${ }^{102}$ CISCAR CASABÁN, Consuelo en VV.AA. "The Real Thing. Arte Contemporáneo de China". Op. Cit. Pág. 9.

${ }^{103}$ GROOM, Simon en VV.AA. "The Real Thing" Arte contemporáneo de China. Op. Cit. Pág. 16.
} 
cuya única satisfacción era saber que había realizado una obra conforme a la espiritualidad y unión con el universo.

- "Esta ha sido la difícil labor del artista indio (Jilpin) que siempre anónimo, dedicó su esfuerzo como si se tratara de una oración o un sacrificio a una obra concreta para un lugar, tiempo y ritual perfectamente definidos, quedando así al margen del artista y la obra de arte occidental exhibida en las actuales galerías de arte. Renuncia a su protagonismo, pero se purifica al participar de la obra creadora de la naturaleza, (...),104.

Todo este devenir occidental, aparece conforme el hombre se ha ido alejando de la religión y se ha ido formando una cultura más laica, pues el arte también ha ido perdiendo su espiritualidad y su magia. A partir del siglo XIX, los artistas no estaban por la labor de mirar atrás en el tiempo, querían avanzar y participar de la política, la cultura y los problemas de su sociedad.

- "El siglo XIX europeo conoció una tendencia revolucionaria de fondo, en torno a la cual se organizaron el pensamiento filosófico, el político y el literario, la producción artística y la acción de los intelectuales" ${ }^{\text {105. }}$.

El arte moderno se vio marcado por la revolución francesa y a partir de ese momento, entró a formar parte de esa lucha, ya que muchos artistas participaron en ella de forma activa. El arte más que nunca iba unido a la política y a la historia, dejando atrás su faceta mágico-religiosa y espiritual, para buscar la libertad.

- LLa claridad, la evidencia, el compromiso eran la característica fundamental en la que el arte, en su tendencia general, debía inspirarse" ${ }^{\text {,106 }}$.

La ciencia y la técnica entraron a formar parte del arte y el hombre se convirtió en el principal protagonista. Como ejemplo de ello, nos encontramos el arte realista de Courbert.

\footnotetext{
${ }^{104}$ GARCÍA- ORMAECHEA, Carmen. "Las claves del arte oriental”. Op. Cit. Págs. 26 y 27.

${ }^{105}$ DE MICHELI, Mario. "Las vanguardias artísticas del siglo XX". Alianza editorial. Madrid, 1985. Pág.13.

${ }^{106}$ DE MICHELI, Mario. "Las vanguardias artísticas del siglo XX". Op. Cit. Pág. 15.
} 


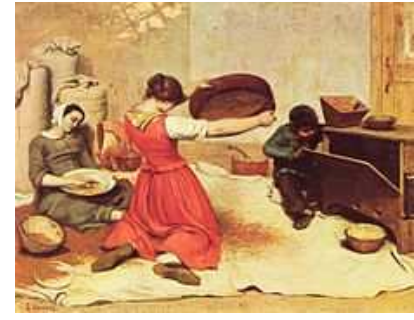

Ilustración 16. Las cribadoras, 1859

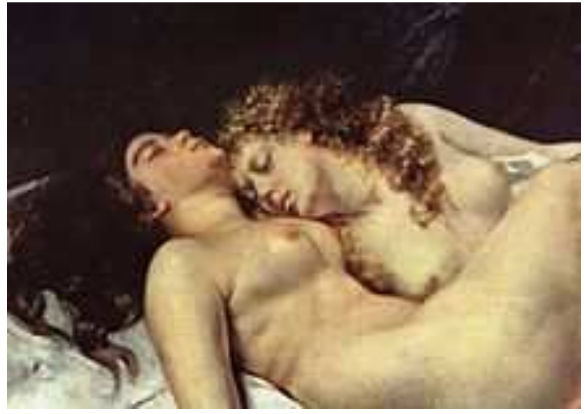

Ilustración 17. El sueño, detalle, 1866

El arte igual que nuestra sociedad se ve corrompido por la avaricia y el deseo de triunfo, todas las facetas de nuestra vida se convierten en una carrera donde lo único válido es ganar, ya no nos vale el hecho y el disfrute de participar.

Es extraño pero a veces nos preguntamos quien se acerca más a lo que podríamos considerar la esencia del arte; la persona que pinta de manera autodidacta por el placer de expresarse en su casa o en cualquier lugar en soledad o quien dedica su tiempo a realizar obras con el único fin de hacer objetos comerciales.

No es una pregunta sencilla y nosotros tampoco poseemos una respuesta concreta, pero pensamos que el declive del arte va unido al descontento con la sociedad. 

4. La obra de arte poseedora de vida y prolongación del artista. 
Para tratar el tema del arte, deberíamos retroceder hasta las primeras señales artísticas creadas por el hombre. Estamos hablando de lo que se ha denominado arte Paleolítico.

El hombre como las demás especies de la naturaleza ha ido evolucionando a lo largo de su vida, y sólo los más fuertes y adaptados al medio en el que vivimos hemos sido capaces de sobrevivir.

La evolución del Hombre le permitió controlar los materiales y las materias primas que la naturaleza le ofrecía aunque de una manera tosca y ruda en sus inicios. Con el paso del tiempo y el incremento de su capacidad cerebral, además de un mejor manejo de los diferentes materiales, también aumentaron sus necesidades de comunicación, sociabilidad y control de los fenómenos naturales y del medio en el que vivía. El Hombre como cualquier ser vivo necesitaba alimentarse, reproducirse, protegerse de las inclemencias del clima, de los depredadores y de las enfermedades. Necesitaba intentar explicar los fenómenos que ocurrían a su alrededor y la mejor manera que encontró fue la religión y la magia. Estos le aportaban la seguridad que necesitaba ante los fenómenos que no podía explicar de una manera racional.

Esta necesidad de dominar las fuerzas de la naturaleza adversas, de cubrir sus necesidades básicas de supervivencia, dieron lugar a la aparición de los primeros dibujos y grabados realizados por el hombre. Este primer arte muestra la realidad inmediata del ser humano. Solían representar escenas de caza, donde aparecían animales solos, en manada o heridos. El lugar elegido para realizar estas pinturas era el interior de las cuevas, convirtiéndose en una especie de santuario o de templo, de lugar sagrado.

- "Grabado y pintura, o la combinación de ambos, dominan en el interior de las cuevas. Las siluetas están completadas con frecuencia con raspados, estriados 0 trazos, para evidenciar los volúmenes. Ésta fue una de las preocupaciones esenciales de los artistas del Paleolítico y explica la utilización de relieves naturales, desde las aristas rocosas, estalactitas y estalagmitas para ciertas representaciones como patas, sexo o senos (...) Fisuras y relievas naturales eran utilizados o retocados para producir los efectos deseados. (...) En cuanto a la paleta, ésta se limita a dos colores básicos: el negro del manganeso (...) a veces alterado tendiendo al azulado o al violáceo, y el rojo de ocre o de óxidos de hierro 
en sus diversas variantes que pueden ir desde el marrón hasta el anaranjado o el amarillo terroso". ${ }^{107}$

El soporte utilizado era la pared de la cueva y los pigmentos, aglutinantes, herramientas, etc, eran materias primas obtenidas de la naturaleza.

La función de estas imágenes era mágica-religiosa. Creían que existía una unión entre la cueva y la realidad, una magia simpática capaz de influir en el hombre o animal representado. Pensaban que si dibujaban un animal herido en la pared, tendrían buena caza y acabarían matándolo.

- "En lo recóndito de las cuevas, los brujos o magos del clan admitían a los iniciados y a los que iban a iniciarse, pintaban o grababan las figuras de los animales y luego danzaban ante ellas y las herían simbólicamente creyendo que así facilitaban su caza y reproducción. En estos santuarios no se representaba la imagen de manera realista con el fin de evitar que pudiera ser objeto de influencias mágicas desfavorables". 108

Como hemos comentado, las cuevas se convertían en un lugar de protección, de templo o santuario sagrado. Por tanto, el arte del hombre primitivo no tenía una función estética sino funcional.

El arte ha ido evolucionando conforme lo ha ido haciendo el hombre, paralelo a sus necesidades en cada momento. Conforme el hombre ha aumentado su raciocinio ha ido creando una brecha cada vez más grande entre él y la naturaleza. Ha pasado de utilizar el arte como un medio mágico, a hacerlo de una manera, estética, revolucionaria, funcional... Ha pasado por grandes cambios estéticos que van desde el esquematismo del arte Paleolítico hasta la abstracción.

Pero hay un nexo de unión entre todas las épocas y todas las obras artísticas realizadas, una serie de metamorfosis que toda obra de arte sufre desde el momento en que es concebida hasta que queda plasmada en dos o tres dimensiones. Estamos hablando de una ensoñación del artista que posteriormente se convierte en una idea, que a su vez se transforma en una imagen, que se acaba convirtiendo en un boceto, que por último dará paso a la creación de la obra.

\footnotetext{
${ }^{107}$ RIPOLL, Eduardo. "Historia del Arte. El arte Paleolítico". Ed. Historia 16. Madrid, 1986. Págs. 25 y 26.

${ }^{108}$ RIPOLL, Eduardo. “Historia del Arte. El arte Paleolítico" Op.. Cit. Pág. 120.
} 
No hay que olvidar que cada artista tiene un estilo propio a la hora de crear sus obras. Esto se debe a que todos somos seres únicos e irrepetibles, que entendemos la vida, la sentimos y la vivimos de modos diferentes. Por tanto, parte de nuestros sentimientos, alegrías, miedos, odios... aparecen representados en las obras de arte. Son el medio de liberación de nuestros sentimientos más profundos, la representación de nuestro inconsciente, nuestra vía de escape, nuestra realidad, nuestro yo oculto... Cada obra posee la impronta de quien la ha realizado, en ella podemos apreciar la fuerza del trazo, la sensibilidad a la hora de realización, la fuerza del artista. Es como si parte de la energía que el autor ha empleado para hacerla haya quedado impresa en ella. La obra de arte se convierte en la prolongación del artista. Y al igual que el cocinero vuelca sus sentimientos en los platos que crea, el artista traspasa su energía vital a la obra de arte. Lo hace desde el mismo instante en que la ensoñación se vuelve materia. Desde el momento, en que algo abstracto se transforma en visual, físico o material.

Por tanto, el arte se convierte en una "herramienta" que acompaña al hombre desde su aparición en este mundo y se ve afectado por los mismos cambios sociales, racionales, políticos e ideológicos que él experimenta. El arte no es algo aislado, comprendido en un periodo de tiempo concreto o periodo específico de la historia. Es el medio en el cual se ven reflejados los sentimientos, los miedos, y las creencias del artista. A lo largo de la historia el arte ha tenido diferentes funcionalidades; mágico-religiosas, educativas, políticas, estéticas...

Los hombres del Paleolítico creían que existía una magia simpática por la cual las escenas representadas en la cueva acabarían siendo una realidad. Por eso, dibujaban sobre todo escenas cotidianas referentes principalmente a la caza, donde los animales solían estar representados con flechas clavadas. Las cuevas para ellos, se convierten en un lugar de culto, una especie de templos o santuarios. En este periodo el arte tiene una funcionalidad, no es meramente estético.

Pero como hemos comentado, el arte evoluciona de una manera paralela a las necesidades del hombre en cada momento de la historia y eso implica que el arte es algo vivo, en movimiento, social... 
Algunos artistas contemporáneos han basado su arte en la realización de fragmentos de sus vivencias, de hechos reales que han ocurrido en el mundo a modo de crítica social o política. Otros han buscado en el arte un medio para acercarse a esa naturaleza cada vez más olvidada por el hombre y encontrar los lazos perdidos que nos unen a ella: un retorno a nuestros inicios, una búsqueda donde el tiempo juega un papel importante. En ambos casos, sus obras de arte son como ventanas que el artista entreabre permitiendo al espectador ser testigo de sus más íntimos sentimientos, sus instintos, sus ensoñaciones y también sus miedos y temores.

A continuación haremos un estudio sobre algunos artistas donde la unión del hombre y el arte parece darse de una manera más intensa como son; Joseph Beuys, Giuseppe Penone y Wolfgang Laib. 



\subsection{Joseph Beuys}


El arte no es independiente a los pensamientos, vivencias, ideas y sentimientos del artista. Las obras artísticas le sirven como medio de difusión y de expresión ante el mundo. Son una prolongación del artista. Su impronta y su energía residen en ellas.

Si estudiamos la vida y obra de Joseph Beuys, podremos darnos cuenta, la unión que existe entre los materiales escogidos a la hora de crear sus obras y sus vivencias personales.

De una manera multidisciplinar, este artista nos acerca a un mundo donde el fieltro, la grasa, la miel y lo animal toman una relevancia y una semántica que sólo él, es capaz de aportar. $Y$ al utilizarlo en sus obras de alguna manera revive su pasado y a su vez nos permite ser espectadores de sus sentimientos, vivencias y conocimientos.

Joseph Beuys nació en Alemania en el año 1921 y murió en 1986 de una afección cardiaca. Demostró ser una persona inquieta e imaginativa, preocupada por la sociedad y la política existente en nuestros días. Declaró abiertamente su rechazo a la guerra de Vietnam y defendió el concepto de que el arte era igual a la vida, y que éste podría cambiar el mundo. Como se puede apreciar, sus ideas políticas y sociales están presentes y forman parte de su obra. No son algo aislado.

El artista es llamado a filas en la Segunda Guerra Mundial y en uno de sus vuelos, el avión que pilotaba se estrelló durante una tormenta de nieve en Crimea y cuando creía que iba a morirse congelado, unos nómadas tártaros lo encontraron y le salvaron la vida. Le curaron y pasó del frío de la nieve, del miedo, de la incertidumbre, de la pena, de la nostalgia, de la resignación a encontrarse untado en una grasa cálida que lo arropaba y envuelto en fieltro como si fuera una especie de crisálida que le aportaba protección, calor, bienestar, imaginamos que sería como volver al útero materno, al hogar. Le dieron miel de abejas para que su cuerpo entrara en calor y debió de sentir como su fuego interno casi ahogado por el frío iba resurgiendo hasta hacerse dueño de todo su cuerpo. 
Debieron de ser momentos muy duros y a su vez muy cálidos. Él sentir el calor de esas gentes que le cuidaban sin pedir nada a cambio, volcar su vida en manos de un extraño cuando el mundo estaba en un momento tan delicado.

Aunque no hay ninguna prueba fehaciente de que estos hechos ocurrieran realmente, basándonos en el estudio de sus obras podemos llegar a creer que son ciertos y que de ellos, nace la constante utilización de estos materiales en sus obras o acciones. No hay que olvidar que Joseph Beuys fue un artista multidisciplinar y realizó performances, happenings, escultura, dibujo, música...

Tras sanar de sus heridas vuelve al combate donde será nuevamente herido y una vez recuperado y con honores, regresa a Alemania. Estudia Bellas Artes y trabaja de profesor de escultura durante un tiempo, pero no estando conforme con el tipo de enseñanza tradicional, se mete en política y funda con otros compatriotas el partido verde y crea su propia universidad, la Freie Internationale University.

Durante un periodo de tiempo su obra podríamos incluirla en la dialéctica del antiarte, pero no buscaba una provocación como ocurre con la obra de Marcel Duchamp, sino que el arte pierda esa imagen de elitismo y privilegio que posee. Busca una unión entre el arte y la vida, entre la sociedad y el arte, entre cada individuo en particular y el arte. Para ello, utiliza materiales pobres y pasa a formar parte del grupo Fluxus, donde trabajan este concepto y dialéctica artística.

Su carácter le impedía aceptar la sociedad tal y como estaba instaurada: Beuys creía en una sociedad más humana donde la creatividad fuera un nexo de unión. Buscaba la libertad que el ser humano había perdido, el acercamiento a lo natural, la defensa del medio ambiente. Para él, todos podían ser artistas, puesto que las acciones formaban parte del arte y todos éramos capaces de realizarlas. Como comenta Bernard Lamarche, (...) para Joseph Beuys cualquiera es artista y la existencia individual y colectiva es el material de todos, ya que la creatividad consiste esencialmente en recuperar la totalidad de los fenómenos como término positivo de pensamiento, de emoción y de 
continuidad del proceder. ${ }^{109}$ No buscaba hacer un arte elitista, ni duradero, ni que sus obras alcanzaran valor por su autoría, buscaba crear un arte para todos. Un arte que escapara de los museos y de las galerías y fuera libre para instalarse en las calles, los parques, las carreteras, etc. Un arte para que todo el mundo disfrutara de él, hecho expresamente para el lugar concreto donde iba a ser expuesto y que fuera efímero. Su arte era igual a vida.

Tras recuperarse de una fuerte depresión que le obligó varios años a estar inactivo, regresa con un arte cargado de simbolismos que nace del estudio por parte de Joseph Beuys de sí mismo y de sus vivencias. Intenta esclarecer qué es el arte, tanto para él, como para los espectadores y a partir de este estudio, sus acciones, obras o instalaciones, recogen una serie de elementos que se convertirán en una constante en su trabajo: la grasa, la miel, el fieltro, lo animal... Era el reflejo de sus ideas políticas, de sus ideas sociales, culturales... Era la prolongación de los pensamientos, vivencias e ideales del artista. Las obras o acciones cobran vida mediante estos elementos repetitivos, porque estos materiales dejan de tener un sentido literal para convertirse en una especie de fetiches, y Joseph Beuys pasa de ser un artista a convertirse en un hechicero o chamán que nos enseña sus ensoñaciones y nos hace partícipes de ellas.

- "El chamán es más que un curandero y un especialista de técnicas extáticas: es, además, el amigo y el señor de las fieras, imita sus voces, se transforma en animal; además, es cantor, poeta, civilizador". ${ }^{110}$

Podemos ver al artista en una de sus acciones hablando con una liebre muerta que acoge entre sus brazos, mientras le explica el sentido del arte. También podemos encontrarlo conviviendo con un coyote salvaje en una galería de Nueva York.

Es la conexión del artista con lo natural, con lo animal, con lo viviente, con lo pensante... se ha convertido en un chamán de nuestro tiempo y el espectador es capaz de contemplar una especie de ritual ancestral adaptado a la sociedad actual. Beuys fue testigo de este tipo de rituales en Mongolia.

\footnotetext{
${ }^{109}$ LAMArCHE-VADEL, Bernard. "Joseph Beuys". Ed. Siruela. Madrid, 1994. Pág. 29

${ }^{110}$ ELIADE, Mircea. "Imágenes y símbolos". Op. Cit. Pág. 178.
} 
- "(...) el modelo del chamán se origina, en efecto, en la organización social y religiosas de las tribus de Mongolia que Beuys entrevió en 1942 y sobre las cuales, no cabe duda, tuvo oportunidad de documentarse posteriormente, asignando a este episodio una función simbólica en el transcurso de su destino". ${ }^{111}$

Una vez más las vivencias pasadas por el artista, se unen a sus inquietudes del presente complementándolo como individuo y reflejándose en su trabajo artístico.

Analizando sus obras podemos ver el valor semántico que el artista da a los cuatro materiales anteriormente nombrados. También aparece el concepto de nómada porque hace mención al cambio, al movimiento, a la libertad, a la naturaleza, etc. Y el bastón, que reporta al artista a su niñez, cuando caminaba por el campo y soñaba con ser pastor.

${ }^{111}$ LAMARCHE-VADEL, Bernard. "Joseph Beuys". Op. Cit. Pág. 3. 



\subsection{1. "I like America and America likes me". ("Me gusta América. Le} gusto a América"). Acción realizada en 1974.

Su oposición a la guerra de Vietnam y a la política belicista americana era algo sabido por todos, pues hizo pública su repulsa ante estos hechos.

La acción que realizó en la galería Block de Nueva York, no comenzó en el interior de ésta, cómo sería de esperar; sino que empezó en la residencia del artista en Düsseldorf. Una ambulancia recogió a J. Beuys de su domicilio envuelto en una manta de fieltro, lo trasladó a un avión donde una vez instalado (siempre dentro de su manta), emprendió el viaje a Nueva York. Después del aterrizaje, fue trasladado por otra ambulancia hasta la galería de arte donde realizaría la acción. Al estar envuelto en una manta evitó cualquier contacto visual con la sociedad americana, con sus edificaciones y monumentos, con sus gentes, etc.

En la galería le esperaba un coyote salvaje con el que convivió un tiempo y su única defensa ante él era un bastón y la protección de su envoltura de fieltro. Tras conseguir que el coyote se tienda a sus pies, Beuys da por concluida la acción y regresa al avión del mismo modo que había llegado a Nueva York, posteriormente es llevado a su domicilio de igual forma.

El coyote (animal totémico) representaba la cultura india, masacrada por el pueblo americano. Para él, este ataque directo contra los aborígenes se debía más a la capacidad para estar unidos a la tierra, a los animales, a lo espiritual que a la necesidad de ocupación de sus tierras. Los indios tenían una fusión con todo lo que les rodeaba y esto les hacía libres. Esa libertad que Joseph Beuys busca en la sociedad actual, viene representada por el coyote como ser vivo y libre.

- "El enfrentamiento entre el artista y el coyote, y su recíproco amansamiento, simbolizan la reconciliación de la cultura y la naturaleza". ${ }^{112}$

El artista crea esta acción expresamente para el pueblo americano, basándose en su cultura y su historia. Es el retorno al enfrentamiento entre los indios y el hombre blanco, entre la libertad y la opresión, entre la naturaleza y la

${ }^{112}$ LAMARCHE-VADEL, Bernard. "Joseph Beuys". Op. Cit. Pág 35. 
civilización. Es el intento de que en el pueblo americano emane la culpa por la sangre derramada por los aborígenes y aparezca una fraternización y paz entre ambos.

- "Este pacto de solidaridad es sellado por un asesino escocés (que pertenece a la raza de los conquistadores de América) con la erección de una estatua en honor de quien, en su retraimiento, ha hecho olvidar el divorcio entre el hombre y la naturaleza, entre lo social y lo asocial, el domiciliado y el nómada, el hombre blanco y el hombre rojo". ${ }^{113}$

Él, envuelto en fieltro y con un bastón representa el pueblo americano. El fieltro es como una capa protectora que envuelve a la sociedad americana, pero que en su interior es consciente y se siente culpable por el daño ejercido a los indios. Es difícil creer en una sociedad americana que represente la libertad cuando ésta se basa en el exterminio o represión de los pueblos indígenas.

Aquí podemos ver un claro ejemplo de una acción pensada para un lugar y tiempo concreto. No busca el reconocimiento, no concede entrevistas, sólo busca expresar su visión política y social. Su obra es una ampliación de sus pensamientos e ideales. En ella reside la fuerza y la energía del autor, su presencia, su respiración, es una prolongación de su ser.

\footnotetext{
${ }^{113}$ LAMARCHE-VADEL, Bernard. "Joseph Beuys". Op. Cit. Págs 35 y 36.
} 

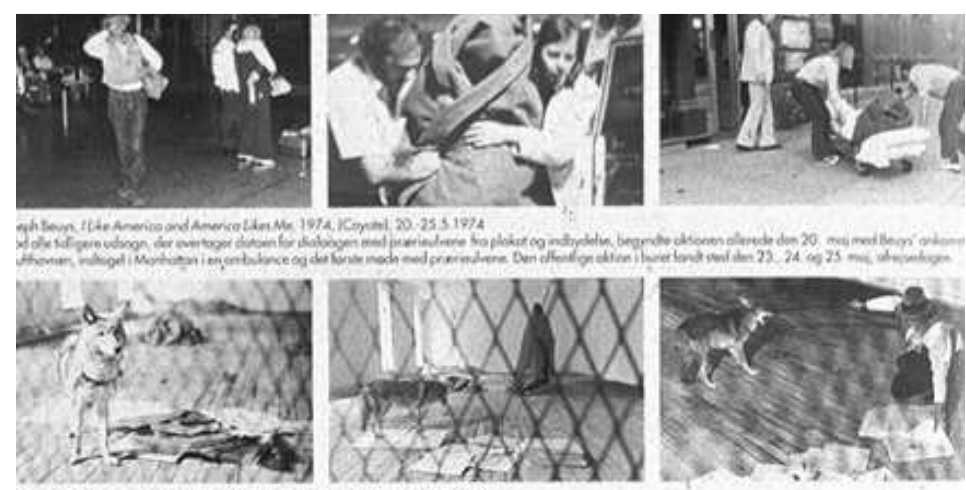

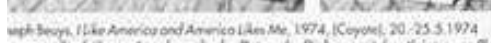

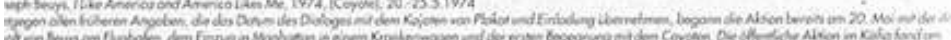

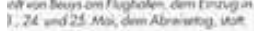

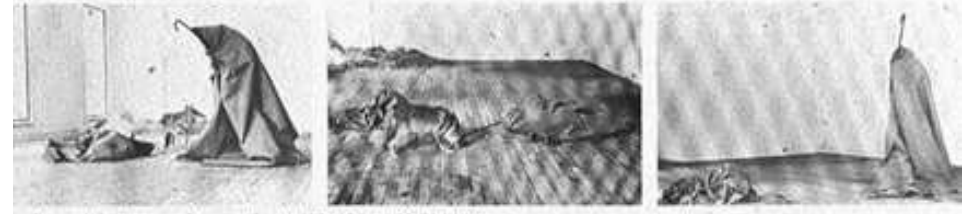

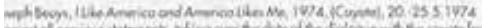
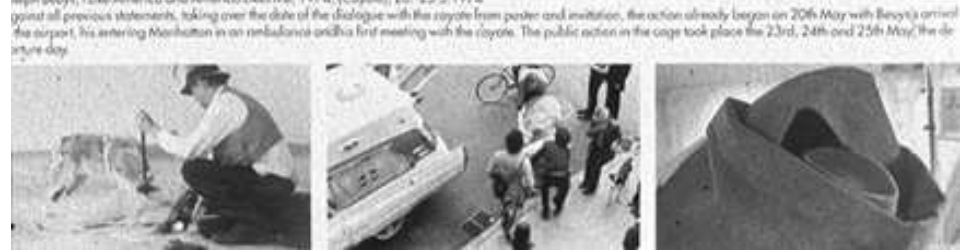

Ilustración 18 . Joseph Beuys I Like America and America Likes Me, 1974. (Coyote) 

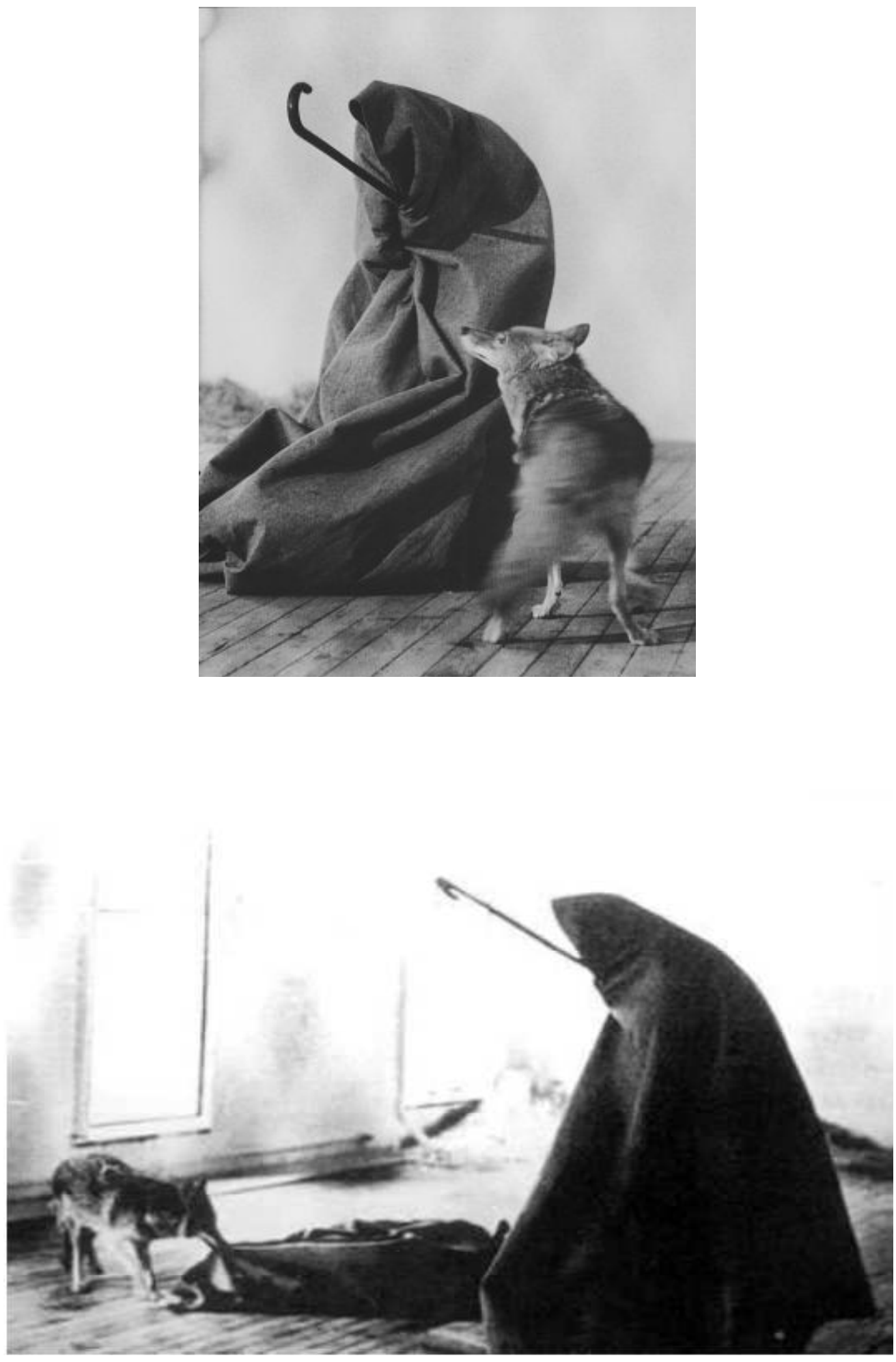

Ilustraciones 19 y 20. Me gusta América. Le gusto a América-1974. 


\subsection{2. "Cómo explicar cuadros a una liebre muerta". Acción realizada en} 1965.

Joseph Beuys realiza una acción en la galería Schmela de Dusseldorf donde el espectador podía ver al artista por medio de una retransmisión desde el exterior de la galería. Éste se encontraba en el interior de un recinto con paredes de vidrio donde había un taburete metálico y un micrófono. El hombreartista llevaba entre sus brazos una liebre muerta que posicionaba como si estuviera acunándola. Al animal, le está explicando una serie de cuadros mientras lleva una capa de polvo de oro y miel colocada en su cabeza. El nivel sonoro es muy bajo, por lo que el espectador apenas escucha sus palabras, es un momento íntimo con la naturaleza, con lo animal, con lo viviente, con lo espiritual, etc. Es una especie de rito o momento sagrado donde reaparece la figura del chamán.

Joseph Beuys en una entrevista con Bernard Lamarche-Vadel en agosto de 1979 nos habla del por qué de la utilización de la figura del chamán:

- "Utilizo este carácter chamanístico para afirmar que no poseemos una comprensión completa de la vida, de la cultura del anthropos. (...) No habría podido descubrir un medio mejor de aclarar los distintos niveles de conciencia, de vida y de cultura que la connotación del chamán. Lo cual asimismo implica una conciencia de todas las energías presentes y de todas las dimensiones espirituales. No es éste el caso de la actualidad, debido a una visión restringida de la antropología y al materialismo que nos aleja de los poderes espirituales". ${ }^{114}$

Cuando toma asiento, el micrófono que hay debajo del taburete, permite al espectador ser partícipe de esa conexión mística que envuelve a la liebre y al artista. En la acción, podemos ver como Joseph Beuys tiene uno de sus pies unido a una superficie metálica provocando ruido con cada movimiento. Por el contrario, el otro pie se encuentra colocado sobre una plantilla de fieltro.

Hay una interconexión entre el animal y él. Nos muestra cómo el hombre puede relacionarse con lo animal, con la naturaleza, con la vida, con la muerte, con lo espiritual. En este caso podríamos hablar de una representación de la existencia original, donde la liebre inerte y quieta, nos hablaría de muerte y el artista con la cabeza untada en miel representaría la vida. Al explicarle las

\footnotetext{
${ }^{114}$ Entrevista de Joseph Beuys con Bernard Lamarche-Vadel, agosto de 1979 publicada en Lamarche Vadel, Bernard. “Joseph Beuys”. Op. Cit. Pág. 72.
} 
pinturas de la galería le está otorgando a la liebre una equiparación con el hombre. Para él, el mundo animal está más unido a la vida, a la supervivencia y a la libertad. Para poseer un pensamiento vivo y creador como la liebre, se unta la cabeza con miel. Esto se debe a que la miel nos aporta calor y energía, y además está creada por otro ser vivo del reino animal, la abeja. Así aleja los pensamientos nocivos de esta sociedad y su pensamiento se vuelve vivo y a la vez está protegido por una capa de metal.
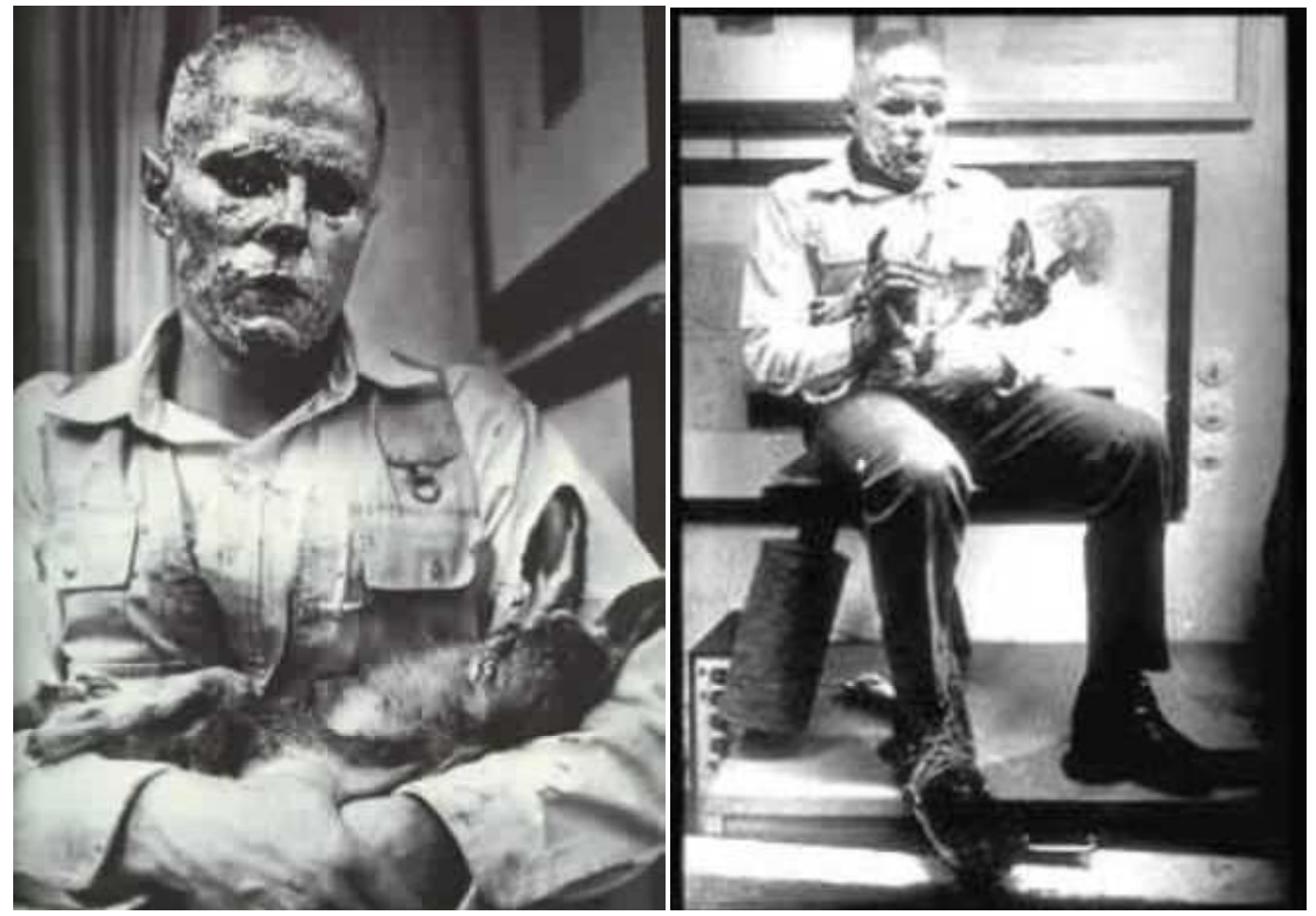

Ilustraciones 21 y 22. Cómo explicar cuadros a una liebre muerta - 1965 
4.1.3. “Bomba de miel en el lugar de trabajo”. Instalación realizada en 1977.

Joseph Beuys creó para la exposición internacional de arte Documenta VI realizada en Kassel en 1977, una instalación que consistía en una bomba de miel que ubicó en la sede de la FIU y de la oficina de información de la Organización para la Democracia. Por medio de tuberías de plástico y dos motores consiguió impulsar la miel desde el sótano a la azotea del edificio. El entramado de tuberías recordaba al aparato circulatorio del ser humano; los motores serían el corazón, las tuberías representarían las venas y las arterias y la sangre sería la miel.

Los motores estaban lubricados con grasa y eran capaces de bombear dos toneladas de miel por el edificio.

Estaba llenando de vida y energía un espacio. Un lugar donde él daba conferencias y hacía charlas sobre política, sociedad, cultura y psicología de nuestra época. Un lugar donde las ideas fluían, estaban vivas y donde la creatividad y la ciencia se convertían en herramientas para cambiar el mundo. Un lugar ahora más vivo que nunca porque en su interior podemos encontrar un aparato circulatorio cálido, energético y vital que nos ayuda a pensar, que nos acerca a las fuerzas creadoras y por tanto, a la libertad.
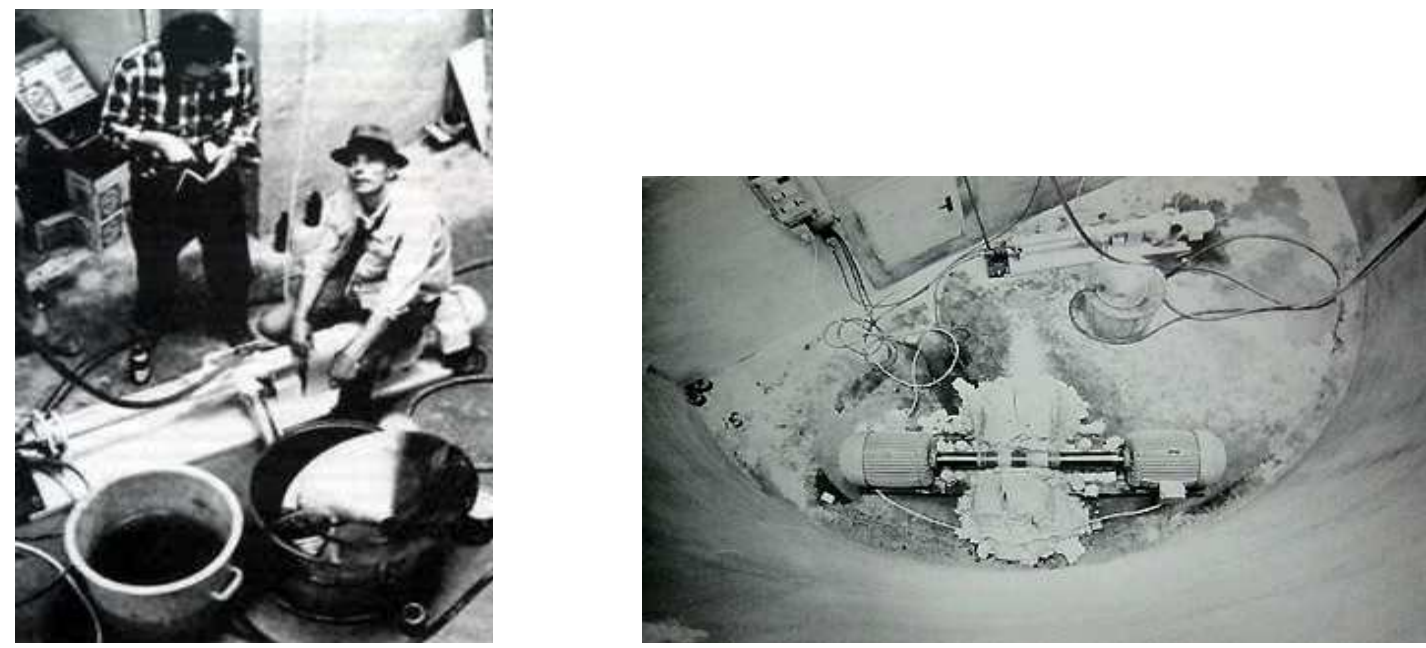

Ilustraciones 23 y 24. Bomba de miel en el lugar de trabajo -1977 


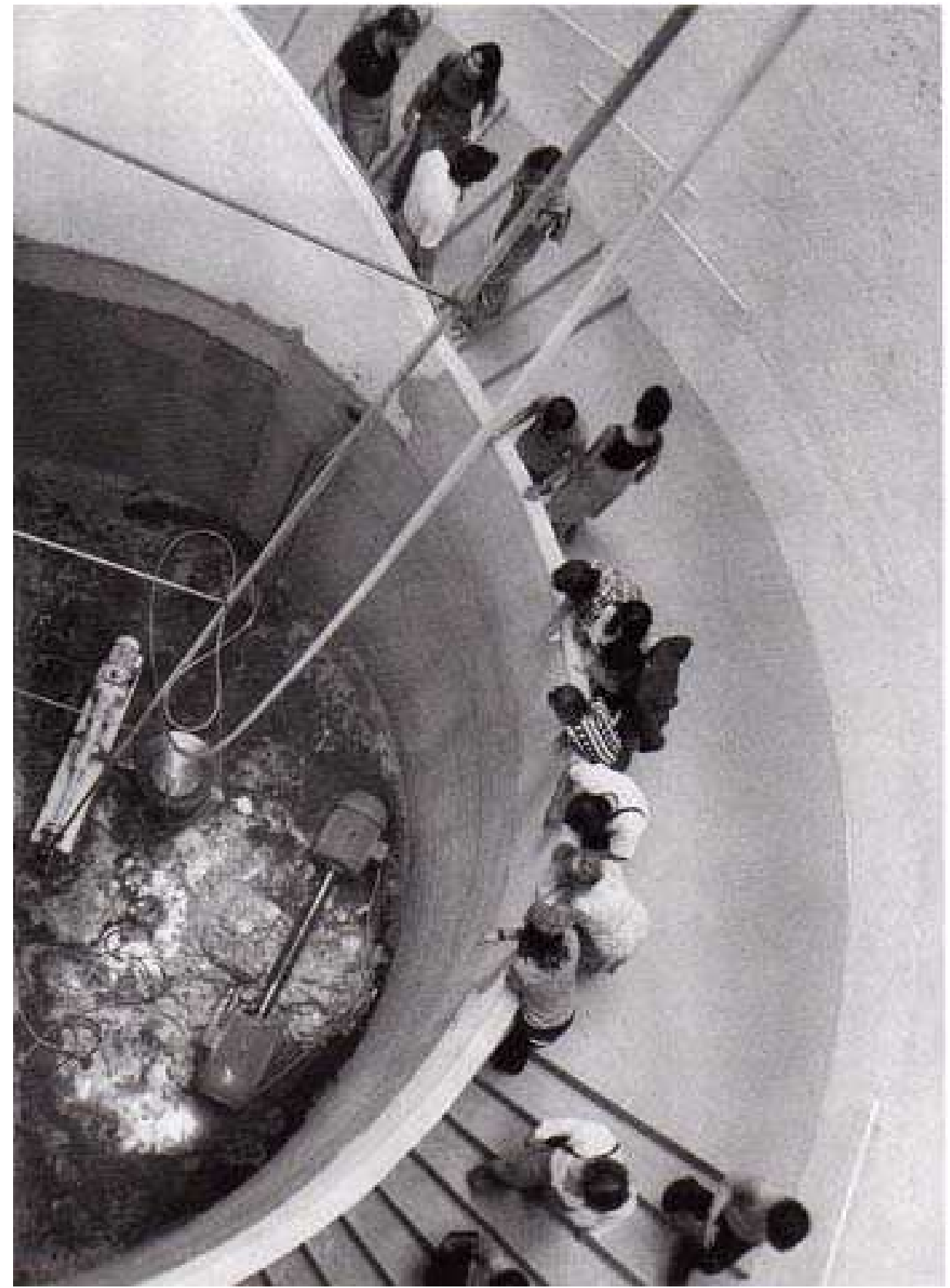

Ilustración 25. Joseph Beuys. Bomba de miel en el lugar de trabajo, 1977 
El fieltro, la grasa, lo animal y la miel son una constante en la obra del artista, así como el concepto de nómada.

El fieltro será uno de los materiales más representativos. Joseph Beuys le otorga un significado semántico de protección, aislamiento y calidez. Es una capa protectora como lo podría ser una crisálida, el calor que desprende su interior nos acerca a la vida, a la candidez, al bienestar, al reposo y a la ensoñación. Su función es mágica, aislante, hace las veces de hogar y de lugar espiritual, chamánico y salvador. El fieltro es una doble piel que nos protege, es la piel del animal, una vestimenta no humana que nos acerca a la vida.

La grasa además de calor y energía nos remite al cambio, al movimiento. Al aplicarle calor se deforma, pero cuando esta fuente calorífica deja de actuar sobre ella, después de un tiempo vuelve a recuperar su antiguo estado. Es por tanto, un movimiento o cambio temporal, no permanente. Esto nos acerca a la visión del arte por parte del artista, donde no busca la eternidad, sino lo efímero y lo nómada.

La miel es otro material que aporta calor y energía. Es creado por las abejas y eso le otorga un aspecto sagrado. Creada por el reino animal, el ser humano puede aprovecharse de sus propiedades al consumirla aportándole energía, calor, dulzura y vitalidad. Tanta, que en ocasiones se puede utilizar como cura o prevención de algunas enfermedades. Este material al igual que la grasa posee la capacidad de cambiar de estado aplicándole frío o calor. Esto hace que no posea una forma eterna, sino de cambio y movimiento como las instalaciones y acciones del autor.

A lo largo de la historia a la miel se la ha relacionado con lo sagrado o místico y le han otorgado cualidades especiales. Esto en gran medida se debe al animal que la crea. La abeja simboliza la vida, la muerte y la resurrección tanto para los antiguos griegos, como para el cristianismo.

"A las abejas se les ha otorgado desde la Antigüedad numerosas cualidades humanas y poderes divinos. Estas cualidades eran según Lucía 
Impelluso; la laboriosidad, la concordia, el valor o la castidad ${ }^{115}$. Todas estas cualidades derivaban del proceso de la creación de la miel. Las abejas desde la Antigüedad han sido muy respetadas y valoradas por ser las creadoras de sustancias tan deliciosas como la miel y la jalea real. En las culturas primitivas se creía que la abeja nacía del toro porque a la miel se la relacionaba con la sabiduría y no hay sabiduría sin sufrimiento, y los bueyes representaban el sacrificio. Esta idea podemos encontrarla en el libro de las Geórgicas de Virgilio:

- "No hay tardanza. Al punto cumple con lo indicado por la madre. Se llega a los santuarios, levanta los altares prescritos, guía cuatro toros que sobresalen por su hermosa estampa y otras tantas novillas cuyo cuello no ha sufrido el yugo. Después, cuando la novena aurora había hecho acto de presencia, envía las ofrendas fúnebres a Orfeo y vuelve a visitar el bosque. Entonces es cuando contempla un prodigio repentino y que causa maravilla decir: a través de las entrañas licuefactas de los bueyes brotaban las abejas por todo el vientre, bullían entre las costillas rotas, se alzaban en nubes inmensas y luego se apiñaban en lo alto de un árbol, de cuyas ramas flexibles pendían como un racimo" ${ }^{116}$

Lo animal, en la obra de Joseph Beuys representa el acercamiento a la naturaleza, a lo viviente, a lo sagrado, a la libertad, a nuestros orígenes. No entiende el desprecio y el concepto de ser superior que tiene el hombre frente a lo animal. El raciocinio en muchos casos no nos lleva a la libertad, sino a políticas belicistas, desigualdad, sufrimiento, pero los animales se mueven por instinto, están unidos a la naturaleza, viven el presente y son libres. Ellos nos acercan a la libertad que tanto ansia el artista y que le gustaría que existiera en nuestra sociedad.

Los materiales anteriormente nombrados acompañaran al artista desde sus comienzos hasta su muerte. Como hemos podido ver, esa unión entre el autor y los elementos nace de un hecho importante en la vida del artista, que si bien no se ha podido corroborar nunca, se cree cierto por la relación e importancia que obtienen los elementos en su obra y porque el propio Joseph Beuys era el encargado de relatar su vivencia con los tártaros nómadas. De ahí, proviene esa búsqueda del movimiento, de lo espiritual, de la vida, de la muerte, de lo natural, del cambio, la fluidez, etc. en su obra.

\footnotetext{
${ }^{115}$ IMPELLUSO, Lucía. "La naturaleza y sus símbolos: plantas, flores y animales". Ed. Electa. Barcelona, 2003. Pág. 334.

${ }^{116}$ VIRGILIO MARÓN, Publio. “Bucólicas/Geórgicas”. Ed. Planeta. Barcelona, 1988 (Libro IV. Pág. 140). 
Recrimina al artista de su época su pasividad ante el mundo y ante la sociedad existente, ante las políticas belicistas, la deshumanización, el poder... porque piensa que la creatividad puede llegar a cambiar el mundo y todos podemos ser artistas puesto que, todos somos capaces de crear e imaginar.

Joseph Beuys se convirtió en uno de los artistas más influyentes de su época en Alemania. Pensamos que se puede comprobar de una manera clara y concisa cómo existe una conexión y una prolongación de sus ideales en su obra. Da igual el medio de expresión que utilice; performance, escultura, música, dibujo... Todos ellos son reflejo de sus ideales, poseen su energía y su fuerza. Es una parte privada del artista, en la que el espectador puede acceder sólo durante un breve periodo de tiempo, porque todo es efímero. Sus obras son claras prolongaciones de su ser y reflejo de sus vivencias. 



\subsection{Giuseppe Penone}


El arte siempre ha ido unido al ser humano y al momento social e histórico en el que se encuentra. Sus necesidades, sus ideales, su política, su sociedad, sus valores... se han visto alterados a lo largo de la historia y el arte ha sufrido cada una de estas transformaciones. El arte paleolítico era un arte basado en las necesidades primarias de alimentación y protección. Su función era mística o sagrada y las cuevas eran un lugar de culto. Hay una interconexión entre el hombre primitivo y la naturaleza que se va quebrando conforme el hombre va evolucionando. El arte deja de tener una funcionalidad para convertirse en algo estético y va adquiriendo valores económicos, estatus social, autoría, etc. conforme se desarrolla la civilización.

Entre el ser humano y la naturaleza se crea una brecha porque el hombre se cree superior a ella y al resto de seres vivos que habitan el planeta. Coloca en un pedestal su raciocinio y otorga niveles inferiores al instinto, a la libertad, a la independencia, a la espiritualidad, a los lazos de unión con el universo y la naturaleza. El arte acompaña estos pensamientos y refleja esas realidades, y en muchos casos el arte se convierte en algo frio, inerte y carente de vida.

En los años 70 nace un movimiento artístico denominado arte Póvera. Podríamos decir que busca retomar esa conexión perdida entre el hombre, la vida y la naturaleza. Trabajan con la energía que fluye de sus acciones o de sus obras, de ese diálogo con lo natural, con lo viviente. Sus obras están realizadas con materiales básicos o pobres sacados de la naturaleza.

- “(..) encontramos en la obra póvera una atención hacia las materia primas en su acepción más literal, primas como primeras. Los artistas nos invitan a volver a los orígenes e introducirnos en el mundo de los cuatro elementos democristianos y a la consideración del artista como hacedor-alquimista-manipulador." 117

Evitaban exponer sus obras en los museos y las galerías porque preferían hacerlo en plena naturaleza. Un monte, un río, una arboleda, una pradera, un valle, un camino, un lago, etc. eran sus ideales expositivos y los materiales empleados eran; hojas, ramas, un río, una piedra, el carbón, polen, tierra, cera, verduras, árboles, arbustos, barro... No querían delimitar su trabajo, querían crear lugares de experiencias, de encuentros.

${ }^{117}$ FERNÁNDEZ POLANCO, Aurora. “Arte Povera” Ed. Nerea, S.A. Guipúzcoa, 1999. Pág. 25. 
Según Miguel Fernández-Cid director del C.G.A.C en 1999, para el artista italiano Giuseppe Penone, la naturaleza (el río, la piedra, el árbol) es arte y el hombre es artista en tanto que es naturaleza, en tanto que repite los comportamientos escultóricos de la naturaleza. No se trata de imitar sus resultados sino de acercarse, de entender los procesos de transformación: "El hombre no es espectador o actor sino simplemente naturaleza". ${ }^{118}$

Para él, una piedra que ha sufrido una erosión o una deformación por el efecto del tiempo o por los fenómenos atmosféricos, se convierte en una escultura creada por la naturaleza. El musgo y la erosión son las pátinas que la colorean.

Con la utilización de estos materiales, las obras se vuelven dinámicas, efímeras, cálidas, naturales... Esto lleva al artista a crear una unión entre el lugar expositivo, la pieza y el autor. El proceso adquiere gran importancia porque nos acerca a nuestros orígenes, no sólo por estar en la naturaleza; sino porque el hombre retorna al ser primitivo que utilizaba las materias primeras para elaborar su arte y los utensilios necesarios para la vida, se convierte en ser manipulador.

- "El artista es, por definición, homo ludens pero sin dejar de ser sapiens y, por supuesto, faber, hacedor, constructor febril y curioso bricoleur. Los materiales han dejado de ser los oficiales. Todo vale, porque con todo entran en relación directa. (...) La materia se expresa y el artista escucha con avidez. Todo habla: el agua, el fuego, la tierra, el aire, los materiales que ayudan al hombre a sobrevivir, los fardos de heno, la estopa, el carbón, así como también los modernos, la electricidad, el neón. Los materiales organizan la obra, y en el corazón de esa transformación se encuentra la energía, por eso se huye de una estática determinación de las formas, se acude a su devenir y se pone especial atención en el proceso". ${ }^{119}$

Nos ofrecen una mirada nueva ante la naturaleza, podemos sentir la energía que cohabita en las obras y que proviene del artista. Tanto de sus pensamientos, como de su fuerza, su visión, sus sentimientos... son poseedoras de la ensoñación, la mirada poética y romántica del autor.

\footnotetext{
${ }^{118}$ PENONE, Giuseppe citado por FERNÁNDEZ-CID, Miguel en VV.AA tras comentario propio. "Giuseppe Penone, 1968-1998: 22 Xaneiro-4 abril 1999". Edita Centro Gallego de Arte Contemporáneo. Santiago de Compostela: Xunta de Galicia, D, L.1999. Pág. 12.

${ }^{119}$ FERNÁNDO POLANCO, Aurora. "Arte Povera". Op. Cit. Págs. 27 y 28.
} 
Algunos artistas que pertenecen o han pertenecido al arte Póvera son Mario Merz, Fabro, Penone, Giovanni Anselmo y Michelangelo Pistoletto. Dentro de este grupo de artistas, puede que sea Giuseppe Penone quien refleja más claramente la idea de entender la obra de arte como prolongación del artista y poseedora de vida

Giuseppe Penone nació en 1947 en Garessio. Se crió en una granja, con lo cual sus primeras experiencias y recuerdos giran en torno a la naturaleza; a la lluvia, al viento, los árboles, el rocío, los olores, la tierra, el agua, las hojas, la luz, etc.

Tras varios años fuera de su hogar, periodo en el que estudió Bellas Artes, regresó a Garessio y comenzó a intervenir en un bosque cercano a su casa. Era el reencuentro del artista con sus vivencias, sus miedos, sus ensoñaciones, sus recuerdos... era el retorno a sus orígenes.

Las obras que Giusepe Penone realiza están unidas a sus raíces. La importancia que en su infancia tuvieron las materias primeras todavía sigue viva en el interior del artista. Los lugares donde soñó de niño, ahora le sirven de lugar expositivo. No le son ajenos, sino que forman parte de él, son su prolongación, poseen su energía y respeto. Crea una unión visual, sentimental y sensible entre el lugar expositivo y la obra creada. Ésta, respeta a la naturaleza y se funde con ella, intenta encontrar con sus obras los lazos perdidos del hombre con la naturaleza, un retorno a nuestros orígenes, una fusión entre lo natural y lo cultural. Para ello, hay que dejar de lado lo que la sociedad nos ha enseñado e intentar ver el mundo como lo hacían nuestros ancestros, sólo así seremos capaces de sentir, imaginar, soñar y crear como ellos. A partir de ese momento seremos conscientes y capaces de usar lo aprendido para conseguir nuestros objetivos.

Como hemos visto anteriormente, para el artista italiano Giuseppe Penone, la naturaleza (el río, la piedra, el árbol) es arte y el hombre es artista en tanto que es naturaleza (...)

- $\quad$ "El hombre no es espectador o actor sino simplemente naturaleza"120

\footnotetext{
${ }^{120}$ PENONE, Giuseppe citado por FERNÁNDEZ-CID, Miguel en VV.AA tras comentario propio. "Giuseppe Penone, 1968-1998: 22 Xaneiro-4 abril 1999".Op.Cit. Pág. 12.
} 
- "Una piedra que se levanta de la tierra por efecto de la lluvia, del rocío. Una piedra que vive las variaciones de humedad del ambiente en el que se encuentra es escultura al aire libre". ${ }^{121}$

- “ ¿Tiene aún sentido repetir que las únicas esculturas del subsuelo son las patatas, los nabos, las raíces, las semillas que germinan?". ${ }^{122}$

Las esculturas del subsuelo antes nombradas, también aparecen en su obra "Patatas" (“Patates”). En ella, el artista creó un habitáculo, lo rellenó de tierra y plantó unos moldes huecos con la forma de algunos de sus órganos de los sentidos (nariz, boca y orejas) y unas patatas, al cabo de unos meses, al recolectarlas, las patatas habían crecido y poseían la forma de estos órganos sensoriales. Se habían convertido en esculturas naturales.

El tiempo es un elemento presente en su obra porque la mayoría de sus piezas como hemos comentado, son efímeras, otras necesitan el paso de meses o décadas para concluirse e incluso algunas seguirán en constante movimiento después de su muerte, como en su obra titulada Alpi Marittime Continuerà a crescere tranne che in quel punto. Se crea un movimiento y cambio constante de la obra conforme el árbol crece envolviendo a la mano de bronce del artista incrustada en él desde que éste era joven. Se dará una alteración continua y unión entre ambos elementos, mientras que el árbol siga creciendo, es decir, mientras siga vivo.

Esto se debe, a que Giuseppe Penone no siente la madera como algo sólido y quieto, sino como algo vivo, en movimiento, fluido. También le otorga a la piedra las mismas características.

- "Desde finales de los sesenta quiso ser río tallando piedras a imitación de los cantos rodados, ser árbol repitiendo el bosque, ser viento dejando la huella de su aliento sobre el follaje, ser paisaje descubriendo los accidentes de la propia piel del interior del cráneo...." 123

\footnotetext{
${ }^{121}$ PENONE, Giuseppe citado por FERNÁNDEZ-CID, Miguel en VV.AA “Giuseppe Penone, 1968-1998: 22 Xaneiro-4 abril 1999".Op.Cit. Pág. 12.

${ }^{122}$ PENONE, Giuseppe citado por FERNÁNDEZ-CID, Miguel en VV.AA. “Giuseppe Penone, 1968-1998: 22 Xaneiro-4 abril 1999". Op. Cit. Pág 13.

${ }^{123}$ elena.vozmediano.info/giuseppe-penone/ (31-05-2015 a las 9:58h).
} 
En la obra del artista se pueden ver sus inquietudes, su sensibilidad ante la elección del lugar expositivo, la importancia del proceso de creación, el amor y la energía que ha desprendido desde que era una simple idea, hasta su transformación en obra de arte. La satisfacción de los resultados y la unión espiritual y mental que se alcanza al dejar entrar al espectador en una parte íntima y privada de su vida.

Las obras realizadas por el artista son el mejor medio para ver reflejado todo lo dicho hasta el momento. En gran parte de ellas, el elemento tiempo o los fenómenos atmosféricos juegan un papel muy importante en la pieza. La autoría del artista en algunos casos es compartida por la naturaleza, desapareciendo ese antropocentrismo típico de nuestra cultura. En el libro "La construcción de la naturaleza" de José Albelda y José Saborit podemos leer que desde otra perspectiva, la pérdida de protagonismo se concentra en una autoría compartida. La obra no la concluye el artista con sus manos, hay una voluntaria renuncia al control absoluto-que por otra parte siempre es ficticio- $y$ una concesión a la aleatoriedad de los procesos naturales que contribuirá a la formación de la obra y a darle su sentido final. ${ }^{124}$

\footnotetext{
${ }^{124}$ ALBELDA, José y SABORIT, José. "La construcción de la naturaleza". Edita Direcció General de Promoció cultural, Museus;Belles Arts Consellería de Cultura, Educació i Ciéncia. Generalitat Valenciana, 1997. Pág. 158.
} 

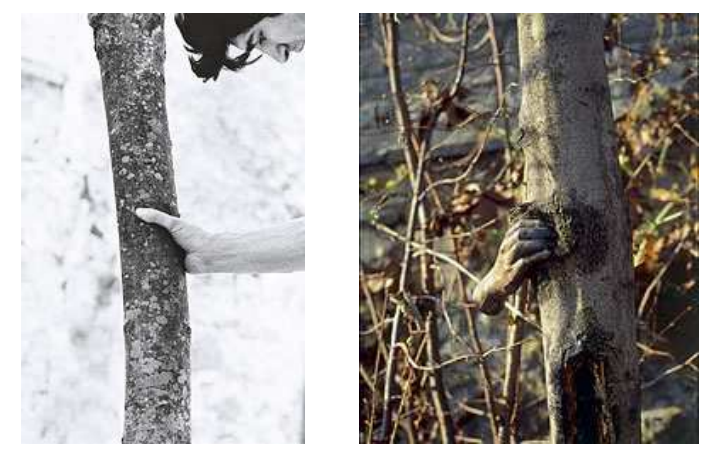

Ilustración 26. [Alpes Maritimos. Continuará creciendo excepto en aquel punto], 1968 Vista tomada durante la realización de la obra Ph. Claudio Basso 1968.

Acero, arbreVue tomada en un momento de crecimiento del árbol Ph. Giuseppe Penone y Dina Carrara, 1978.

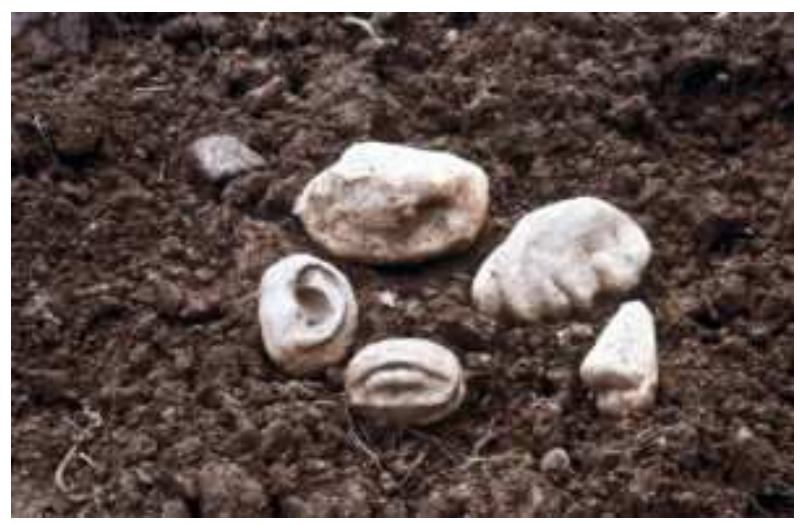

Ilustración 27. "Patatas" ("Patates") realizada en 1977. 

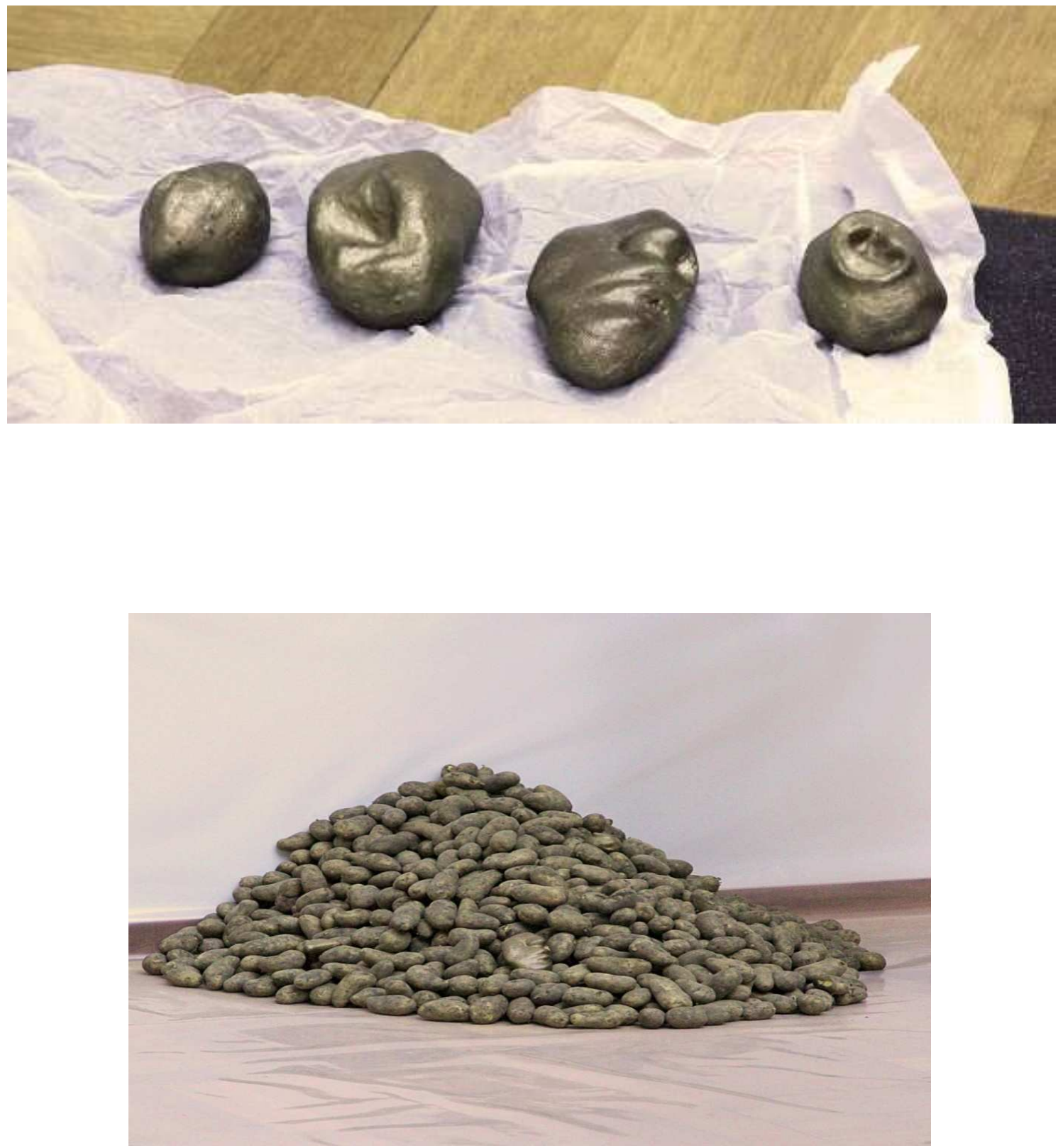

llustraciones 28 y 29. Patatas con forma de ojos, oidos, nariz y boca. Giuseppe Penone. Basler Kunstmuseum 
4.2.1. “Piedra, cuerda, árbol, sol/Piedra, cuerda, árbol, Iluvia”. Escultura realizada en 1968.

El artista coloca en una zona concreta de un bosque, una piedra unida a un árbol por una cuerda vegetal. Existen unos metros de separación entre ambos elementos. La lluvia y el rocío del ambiente, tensan la cuerda elevando así, la piedra. Cuando la cuerda se dilata a causa del buen tiempo, la piedra vuelve a descender lentamente hasta el suelo. Comenzando el ciclo de nuevo. La piedra se convierte en una escultura al aire libre.

Todos los materiales son naturales, cohabitan perfectamente con el lugar expositivo. Su intervención no es eterna, porque el tiempo hará mella en ella, desgastándola y erosionándola. Su movimiento es aleatorio, no depende de él, está en manos de la naturaleza.

Nos enseña como un simple gesto o acción puede llegar a ser una intervención artística. Detrás de cada una de las acciones realizadas por Giuseppe Penone, hay un gran estudio y un claro pensamiento del objetivo que se quiere alcanzar.

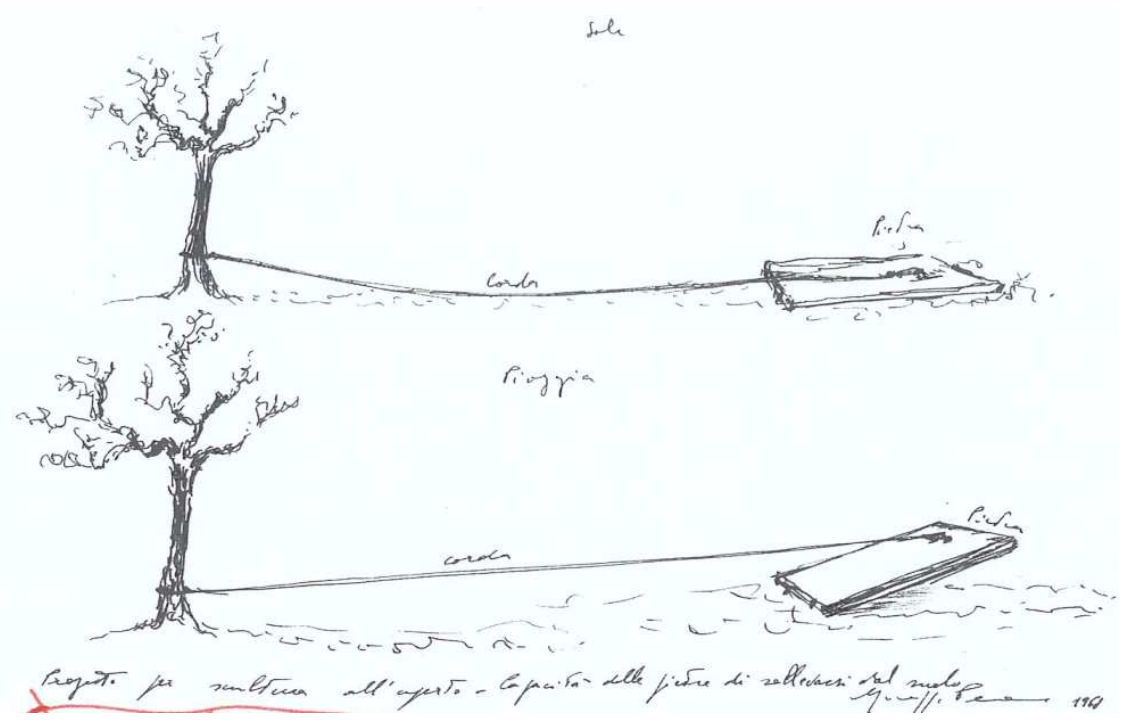

Ilustración 30. Proyecto para escultura al aire libre. 
4.2.2. "Ser río" ("Essere fiume"). Esculturas realizadas desde 1981.

En esta obra, Giuseppe Penone nos presenta dos piedras rodadas aparentemente iguales, donde la diferencia reside en que una está sacada del lecho del río con las erosiones, las fracturas y el desgaste que el viaje desde la montaña al lugar donde es rescatada por el artista le han provocado y la otra piedra posee las mismas incidencias físicas debido a que el artista ha intervenido en ella, de manera escultórica.

Ambas piedras pertenecen a la misma zona de montaña, donde el río pasa por debajo de ellas.

En esta obra podemos apreciar cómo el artista equipara las herramientas de trabajo del escultor con los materiales naturales que han hecho posible que la piedra sacada del río se encuentre en ese estado; las piedras, la arena, la corriente, el agua se convierten en cinceles, en papel de lija, en punzones, etc.

El concepto tiempo también es un elemento importante en la obra, puesto que el río ha tardado varios siglos en conseguir transformar la piedra tal y como nos la presenta Penone, mientras que él, ha reducido ese tiempo drásticamente al mimetizarla.

Todo tiene un fin, todo se deteriora; los materiales nobles, la madera, la piedra... pero en algunos casos este proceso es tan lento que no podemos ser conscientes de ello, pero tarde o temprano todo desaparece, da igual que hablemos de una pieza en bronce, de mármol o de un mariposa.

El llegar a entender y a equipara al río como escultor y ser capaz de buscar el lugar originario de la piedra y decidir imitarlo, no es un proceso al que se llegue sin pensar, sin sentir, sin imaginar. El artista ha llegado a ponerse en el lugar del río, ha llegado a sentir como él, se ha convertido en él. Su visión temporal unida a los elementos naturales utilizados en sus obras, nos acercan a los pensamientos íntimos del artista, a sus dudas y su concepción del mundo.

Sus obras reflejan las horas de estudio en la naturaleza, la unión entre el hombre y ella, el transcurrir del tiempo, la fluidez de los materiales, el movi- 
miento. Son obras con una energía vital increíble donde el espectador es consciente de esa unión hombre-naturaleza que intenta rescatar el artista de nuestra memoria olvidada.

\begin{abstract}
"El golpearse de las rocas durante el curso de las crecientes, el frotamiento incesante de la arena en suspensión, el movimiento continuo de las aguas sobre el fondo, provocan el muy lento desplazamiento de las grandes rocas, el lento movimiento de las piedras de dimensiones medianas, el curso más rápido de las piedrecillas, el escurrir acelerado de la arena fina, verdadero río dentro del río. (...) El río transporta la montaña. El río es el vehículo de la montaña. Los golpes, los choques, las violentas mutilaciones que el río inflige a las rocas más grandes golpeándolas con otras más pequeñas, la infiltración de las aguas en los brazos más delgados, en las fallas, desprenden pedazos de bloque. Todo sirve para esbozar la forma-efecto de un trabajo continuo de erosión, de presión sorda. La forma se dibuja y se evidencia. ¿No tiene únicamente el río, como proyecto, revelarnos la esencia, la cualidad más dura, la más secreta, la densidad extrema de cada elemento de la piedra? [...] Imposible imaginar, imposible trabajar la piedra según un modo diferente del que utiliza el río. El punzón, la broca, la tijera, el abrasivo, el papel de lija, son útiles mismos del río. (...) Extraer una piedra que el río ha esculpido, retroceder hacia la historia del río, descubrir el lugar preciso de la montaña desde donde la piedra ha venido, extraer de la montaña un bloque nuevo, reproducir en éste exactamente la piedra extraída del río, es ser río uno mismo. [...] Para esculpir la piedra realmente, hay que ser río». ${ }^{125}$
\end{abstract}

\footnotetext{
${ }^{125}$ PENONE, Giuseppe. [1988], citado por Georges Didi-Huberman en su obra "Ser cráneo. Lugar, contacto, pensamiento y escultura". Ediciones de Medianoche. Que a su vez es citado desde G.Celant, Giuseppe Penone, trad. A. Machet, Milan-Paris, Electra-L\&M. Durand-Dessert, 1989. Pág.110 en http://www.facartes.unal.edu.co/catedra_creacion/craneo.pdf (09-06-2015 a las 10:26h).
} 


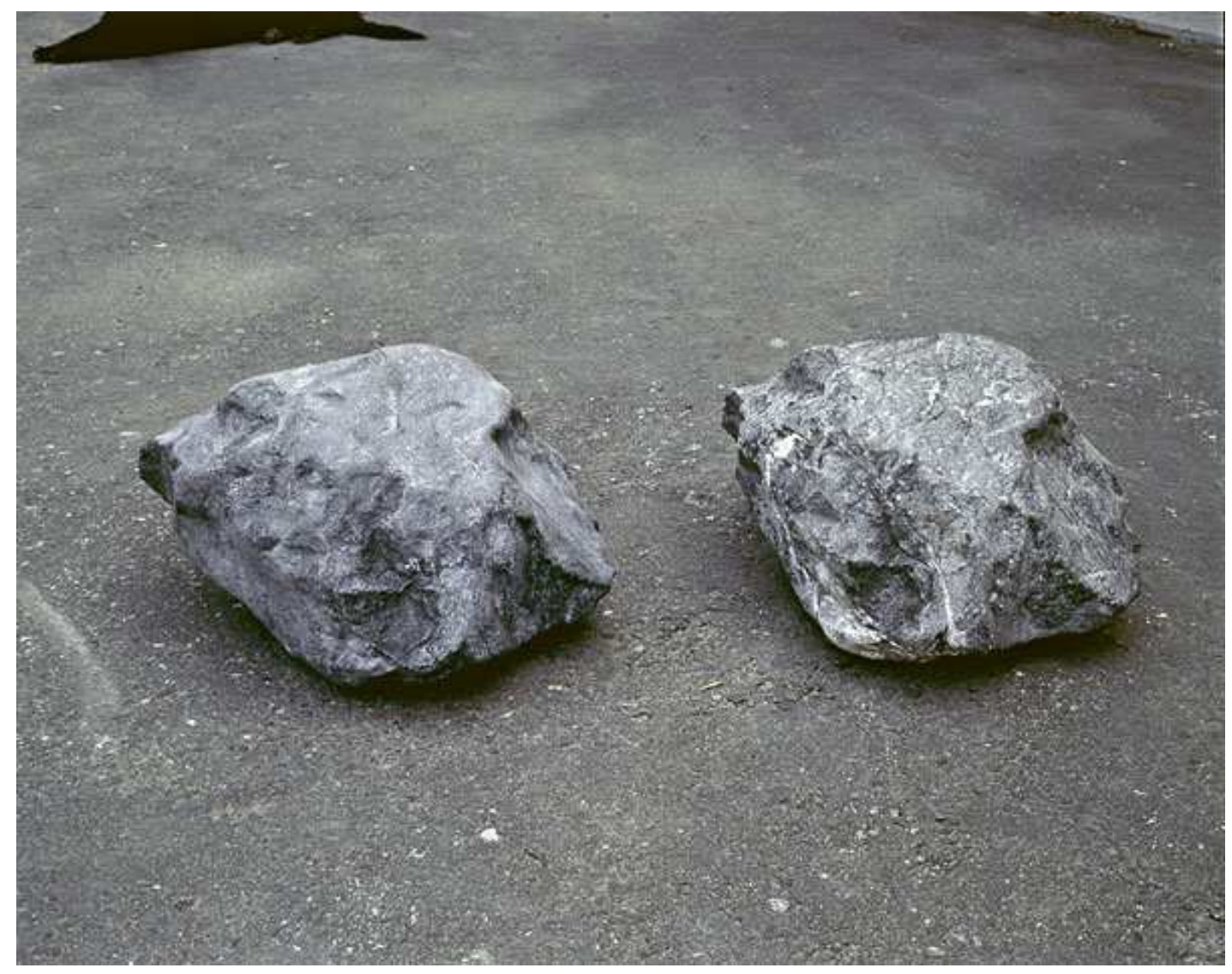

Ilustración 31. Être fleuve 1 [Essere fiume 1], 1981. Pierre naturelle et pierre taillée. (Ser río), 1981. Piedra natural y piedra tallada. Ph. Salvatore Mazza, 1981 


\subsection{3. "Repetir el bosque" (Ripetere il bosco"). Obras realizadas desde} 1969.

En estas obras Giuseppe Penone busca "revivir" o devolverles la noción de árbol a las maderas que nos acompañan en nuestra vida cotidiana tras un proceso industrializado (mesas, vigas, postes, sillas...), para que la memoria de lo que fueron y en lo que se habían convertido siga viva tanto en la mirada del espectador como en la propia materia, el artista deja un espacio de la madera sin trabajar, el resto sufre un proceso por el cual, va retomando su condición de árbol.

Para ello, realiza un estudio de sus aros de crecimiento, con el fin de determinar su edad y comienza a retirar mecánicamente la madera, para dejar al descubierto las ramas y el tronco que esa madera ya poseía anteriormente.

Sus obras albero-porta están basadas en el mismo planteamiento que hemos comentado, creando en un tronco una puerta que nos enseña el corazón del árbol.

El árbol simbólicamente, para gran número de culturas a lo largo de la historia, ha estado relacionado con la vida, con la creación y en este caso, es el artista quien ha actuado como creador, devolviéndole al material, su forma y esencia original.

En el libro de Mircea Eliade "Imágenes y símbolos” podemos ver cómo, la variante más extendida del simbolismo del Centro es el Árbol Cósmico, que se halla en el medio del universo, y que sostiene como un eje los tres Mundos. La India védica, la antigua China, la mitología germánica, así como las religiones "primitivas", bajo formas diferentes, conocen este Árbol Cósmico, cuyas raíces se hunden hasta los Infiernos y cuyas ramas tocan el Cielo". ${ }^{26}$

Es un acercamiento del hombre con la naturaleza que nos envuelve cada día y a cada momento. Guy Tosatto al hablarnos de la obra de Giuseppe Penone, nos dice que la evidente diferencia entre la percepción del material madera y su relación con su forma originaria, el árbol, se diría que traduce la dificultad que, en nuestros días, encuentra el hombre de la civilización urbana

\footnotetext{
${ }^{126}$ ELIADE, Mircea. "Imágenes y símbolos". Op. Cit. Pág.47
} 
de reconocer y, por consiguiente, de admitir la aparición de la Naturaleza en su entorno, que se vuelve cada vez más artificial; y, por tanto, la creciente distancia entre el hombre "natural", que vivía en simbiosis con la naturaleza, y el hombre "cultural", separado de sus raíces originales. ${ }^{127}$

Esta separación es cada vez más notable, en cuanto que el hombre ya no se ve uno con la naturaleza, ni trata al resto de seres vivos como hermanos, sino que se siente superior y capaz de controlar y dominar todo y a todos. Pero esta obra nos hace reconsiderar ese planteamiento: el ser humano siempre tiene la naturaleza cerca, porque la madera, el barro, las patatas, las calabazas siempre poseerán su energía, porque es su esencia. Es un acercamiento entre lo cultural y lo natural.

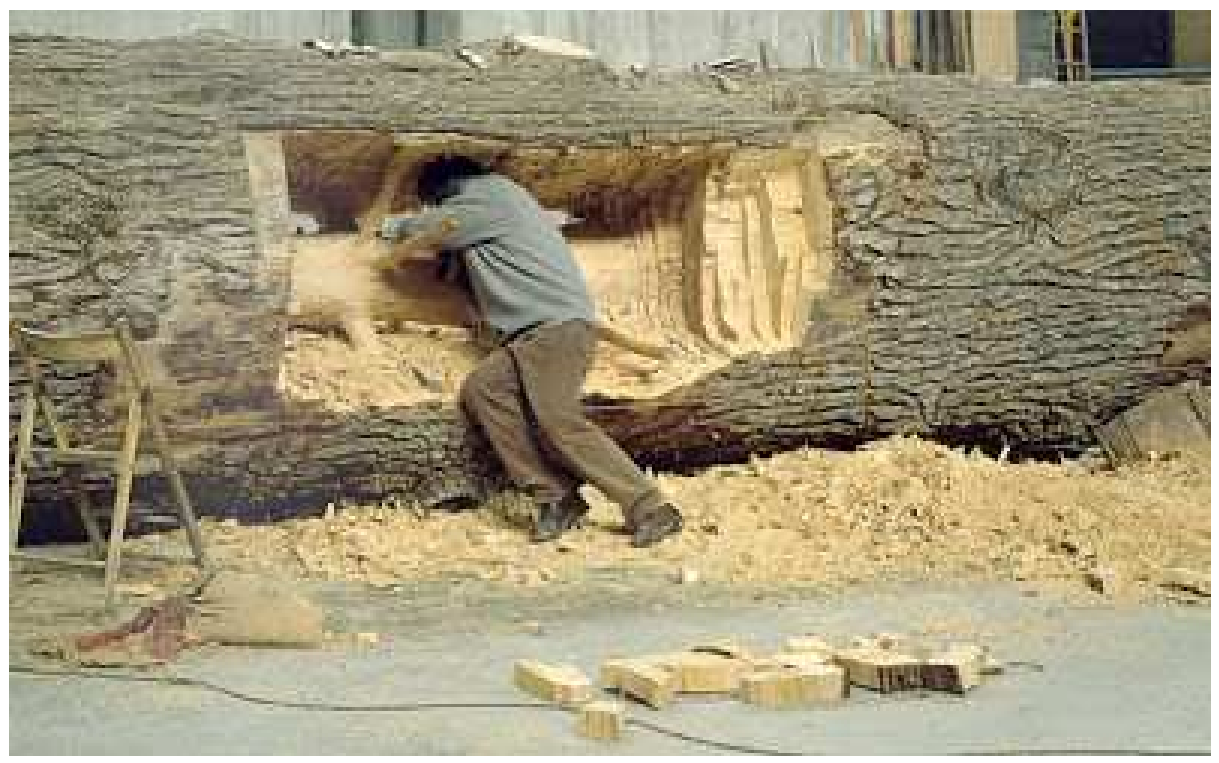

Ilustración 32. G.PENONE travaillant au Cèdre de Versailles, 2000 (G.Penone trabajando el cedro de Versalles,2000)

${ }^{127}$ TOSATTO, Guy en VV.AA. “Giuseppe Penone, 1968-1998: 22 Xaneiro-4 abril 1999”. Op. Cit. Pág. 148. 


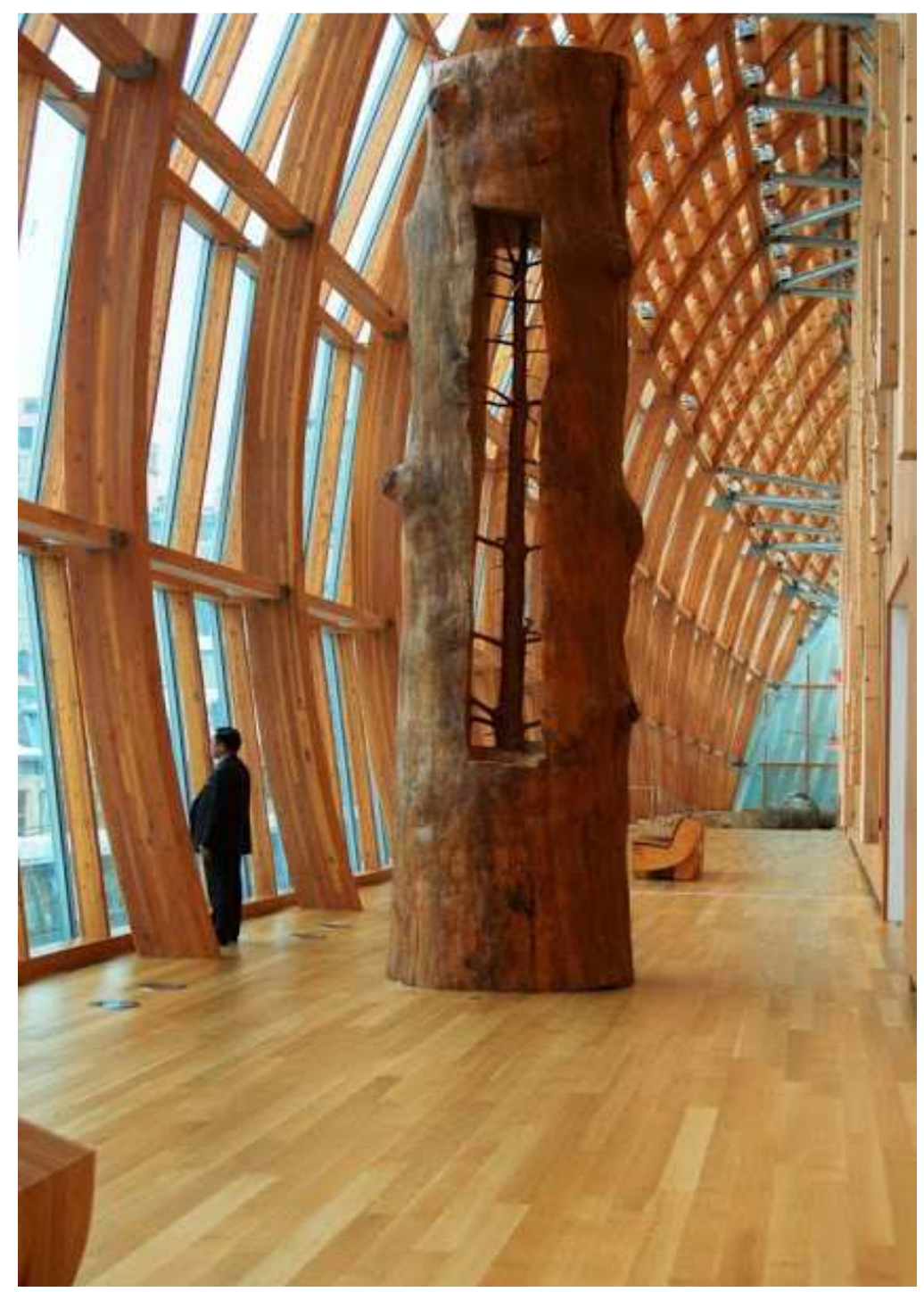

Ilustración 33. Cèdre de Versailles, 2000-2003

(Cedro de Versalles, 2000-2003) 
4.2.4. "Soplo de hojas" ("Soffio di foglie"). Escultura realizada en 1979.

Para su creación el artista sólo utilizó como materiales un montón de hojas de boj colocadas en el suelo y su propio cuerpo. Giuseppe Penone se tumba sobre el montón de hojas y la presión que ejerce su cuerpo sobre ellas, deja impresa su silueta. A la altura de su boca el artista realiza un soplo donde las hojas son movidas por ese aire interno que sale del de su cuerpo dejando plasmada su respiración.

- "El soplo es movimiento. Se concretiza en el hombre con la respiración y, en el universo, con el viento". ${ }^{128}$

Pero el hombre cada vez que inspira deja entrar en su interior parte de la naturaleza que nos envuelve y por el contrario, al expirar devolvemos a la naturaleza parte de nosotros mismos. Es un intercambio mutuo, una simbiosis. Esta sencilla y a su vez tan compleja obra, nos ayuda a darnos cuenta de que formamos parte de un Todo, que se encuentra conectado y que si una parte es dañada, todos sufrimos las consecuencias. Si los bosques (pulmones de la Tierra) son talados en masa, nosotros y todos los seres vivos que compartimos ese soplo de vida universal y que contribuimos a que ese ritmo constante se mantenga, también sufriremos las consecuencias.

Retomando de nuevo un fragmento de la carta del jefe indio Noah Sealth, podemos comprobar la importancia que el viento y la respiración tenían para los indios. Para ellos, era el aliento vital de todos los seres vivos porque todos compartimos el mismo aire y por tanto en cada respiración, estamos absorbiendo parte de ellos.

- "(...) Nosotros preferimos el suave susurro del viento sobre la superficie de un estanque, así como el olor de ese mismo viento purificado por la lluvia del mediodía o perfumado con aromas de pinos. El aire tiene un valor inestimable para el piel roja, ya que todos los seres comparten un mismo aliento-la bestia, el árbol, el hombre, todos respiramos el mismo aire". ${ }^{129}$

En esta obra además de una clara intención por parte del artista de plasmar el soplo, con toda la dificultad que ello conlleva, también intenta materializar, algo tan etéreo, ligero, sutil como es el movimiento del aire, tanto

\footnotetext{
${ }^{128}$ TOSATTO, Guy en VV.AA. “Giuseppe Penone, 1968-1998: 22 Xaneiro-4 abril 1999”. Op. Cit. Pág. 257.

${ }^{129}$ Fragmento carta del jefe indio Noah Sealth, 1.854 www.waste.ideal.es/sealth.htm $(14 / 12 / 12$ a las $9: 30 h)$
} 
representado por la respiración como por el viento, convirtiéndose en una obra muy compleja. Pero ese soplo, no es el soplo de un desconocido, es la propia respiración del artista la que está plasmada en su obra, es como si su aliento vital envolviera a la obra y la llenara de vida, no es algo inerte, respira.
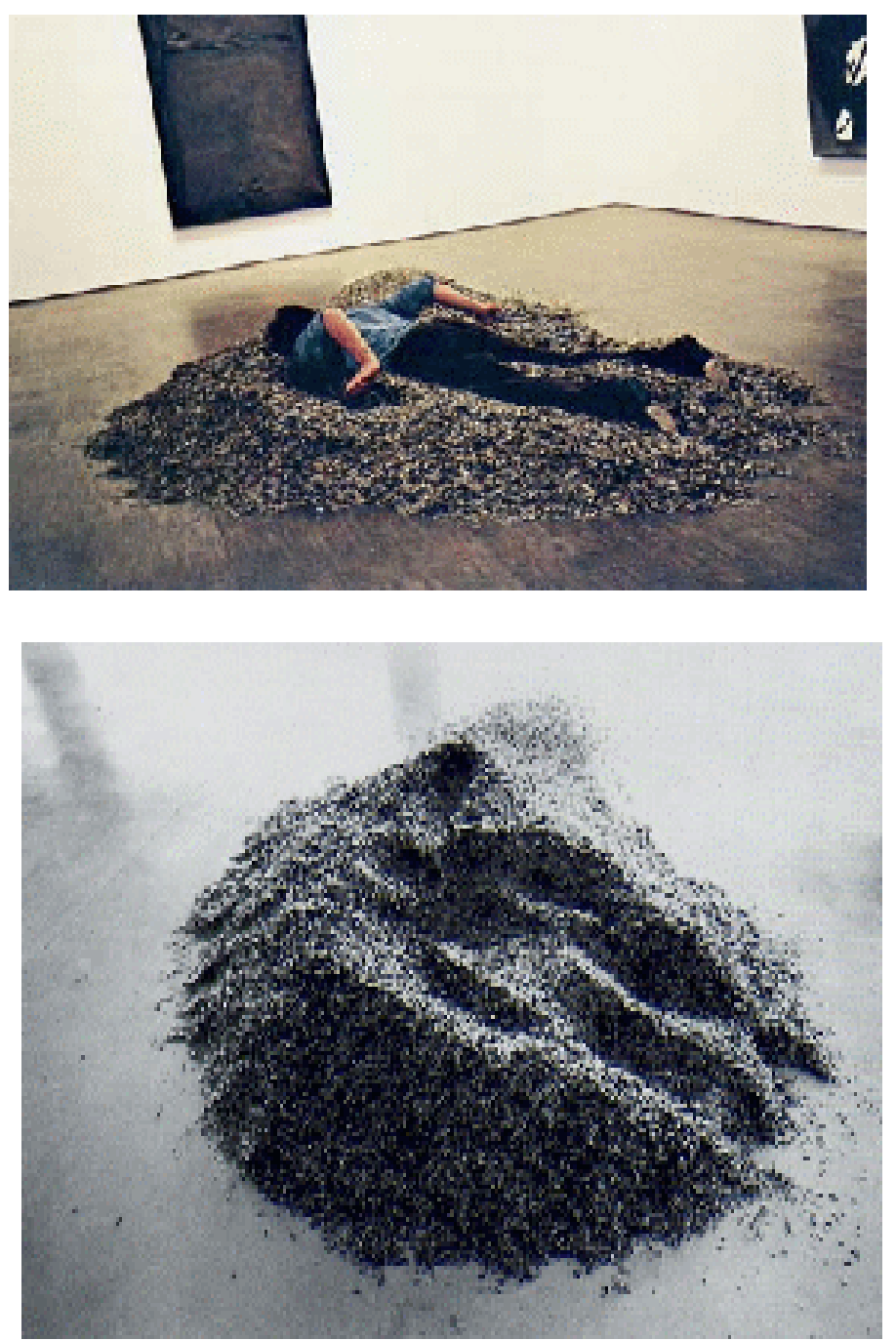

Ilustraciones 34 y 35. Soplo de hojas. Hojas de boj. 1979 



\subsection{Wolfgang Laib}


Además del Arte Povera surgido en la década de los 70, también aparecen otros movimientos similares en años posteriores como es el Land Art. En este movimiento artístico, se sigue actuando en la naturaleza y los materiales usados también suelen ser primarios, pero en ocasiones las obras son lo que se podría denominar una mezcla entre la escultura y la arquitectura. Las dimensiones de las instalaciones artísticas suelen ser enormes, y su objetivo es alterar el paisaje donde se encuentran. Es una manera de que el espectador interactúe con el lugar expositivo y los sentimientos que éste puede llegar a provocarle. No se trata de realizar una instalación que nada tenga que ver con su ubicación, sino que hay un estudio por parte del artista del espacio expositivo y una comunicación con él y a partir de ahí, nace un nuevo paisaje gracias a la visión y el trabajo del artista.

También está influenciado por los trastornos que la naturaleza estaba sufriendo por parte del hombre y sus consecuencias.

Algunos de los artistas que formaron parte de este movimiento son; Robert Smithson, Richard Long, Christo, Andy Goldsworthy y Wolfgang Laib.

De entre todos ellos, hemos seleccionado a Wolfgang Laib para hacer un estudio más detallado de su obra, principalmente por el tipo de material y colorido que se puede apreciar en sus instalaciones, porque es capaz de adueñarse de los sentidos del espectador que ve su trabajo y lo transporta a un mundo místico y espiritual, donde el tiempo se ralentiza y emana de sus instalaciones un sentimiento de paz, meditación, prosperidad y calma.

- $\quad$ "Estas no son ni esculturas de pequeñas y medianas dimensiones, ni objetos, sino más bien enunciados plásticos invitando a la meditación: meditar lo frágil y lo intocable, meditar la materia, meditar la procreación en la naturaleza y el cerebro, meditar el pigmento puro y la riqueza del polen amarillo intenso así como su aroma, meditar la pureza, meditar el tiempo-el tiempo invertido por el artista, su propio tiempo, el tiempo de la naturaleza, el tiempo universal". 130

\footnotetext{
${ }^{130}$ SZEEMAN, Harald citado por AVRILLA, Jean-Marc en VV.AA. "Château de Jau. Musée d'art moderne de Collioure. «<xpositon sentimentale»>". Ed. Musée d'art contemporain de Bordeaux. Bordeaux, 1992. Pág. 15

"Ce ne sont ni des sculptures de petites et moyennes dimensions, ni des objets, mais bien des enonces plastiques invitant a la meditation: mediter le fragile et l'intouchable, méditer la matiere, mediter la procreation dans la nature et le cerveau, mediter le pigment pur et la richesse des jaunes intenses des pollens ainsi que leur senteur, mediter la purete, mediter le temps-le temps investi par l'artiste, son propre temps, le temps de la nature, le temps universo".
} 
El artista nació en 1950 en Metzingen Alemania. Al igual que parte de su familia, estudió medicina pero también se vio cautivado por el estudio del arte. Interesado por la cultura, lenguaje y sabiduría oriental realizó frecuentes viajes a la India y a otros países orientales. Seducido por estas filosofías basó todo su trabajo en crear instalaciones u obras de carácter minimalista, místico y religioso. Otorgando al espectador que los contempla; calma, paz, serenidad, sosiego... el espacio donde se encuentra ubicado su trabajo pasa a convertirse en un lugar sagrado, de meditación. Las obras de Wolfgang Laib son el reflejo de cómo entiende y siente el mundo que le rodea. Es el culto a la sencillez, a la sutileza, a la delicadeza, al color monocromático, al olor, etc. Es el retorno a la idea inicial que nos aparecía en el "l Ching” de que todo está en constante movimiento y lo hace de una manera cíclica. La noche deja paso al día y el día a la noche, la primavera deja paso al verano y éste a su vez, deja paso al otoño, que con su fin da comienzo al invierno y una vez éste concluye vuelve a florecer la primavera y el ciclo se repite indefinidamente.

- "Sus obras son concebidas como un ritual, un proceso integro conectado a un orden cósmico, a la mística de la naturaleza que han desarrollado diferentes culturas y religiones. Sigue un proceso cíclico en el que trata de preservar un sentido de pureza conectada al orden natural lo que implica la recolección de los materiales en las estaciones y lugares específicos, el montaje meticuloso para la exposición y el mantenimiento diario de las piezas, que incluye el reciclado de los elementos que las integran. Un ritual cíclico en el que cada pieza se ha renovado una y otra vez a lo largo de los años, y se amplía el círculo con nuevas creaciones". ${ }^{131}$

Los materiales utilizados por el artista son, naturales; el arroz, la cera de abeja, el polen, el mármol y la leche. Todos ellos aunque simples a la vista, son portadores de una gran simbología. La mayoría de ellos, son efímeros y necesitan de ese mantenimiento y renovación constante en sus obras que deben de realizar las personas del museo o de la galería.

- "Cuando muestro el polen o la leche en cualquier país en el mundo, todo el mundo sabe lo que es el polen o lo que es la leche. Y no tiene nada que ver con el arte alemán o con el arte europeo. Es algo tan universal, cualquier ser humano puede relacionarse con ella sin lenguaje o explicación". ${ }^{132}$

\footnotetext{
${ }^{131}$ www.museoreinasofia.es/exposiciones/wolfgang-laib-sin-principio-sin-fin (10/06/2015 a las 10:51h)

${ }^{132}$ WOLFGANG, Laib entrevistado por SarahTanguy

http://www.sculpture.org/documents/scmag01/may01/laib/laib.shtml

$(10 / 07 / 2015$ a las $16: 14 h)$
} 
El arroz es uno de los alimentos más utilizados en Oriente y se le otorgan algunos poderes curativos y de limpieza tanto física como espiritual. Tal vez por ello, el artista lo utiliza en su trabajo.

La cera como ya hemos comentado al hablar de la obra de Joseph Beuys, hace mención a las abejas y por tanto, a la vida, a la muerte y a la resurrección.

A éstas, como hemos dicho anteriormente, citando de nuevo a Lucía Impelluso se les otorgaban numerosas cualidades humanas y poderes divinos. Estas cualidades eran la laboriosidad, la concordia, el valor o la castidad ${ }^{133}$. La cera se utiliza desde la Antigüedad con diferentes fines y es un elemento importante en muchos procedimientos artísticos como por ejemplo la fundición artística a la cera perdida que trataremos en el capítulo siguiente ampliando las cualidades de las abejas y la utilización y clasificación de la cera.

El artista, para la realización de una de sus obras titulada "NowhereEverywhere", utilizó láminas de cera para crear bloques de cera de abeja, que por superposición formaban la imagen de un zigurat (pirámide escalonada). Detrás de esta figura, existe todo un mundo de simbologías y creencias. Como podemos leer en el libro de Mircea Eliade "Imágenes y símbolos":

- "El zigurat era en realidad una montaña cósmica, es decir, una imagen simbólica del cosmos: los siete pisos representaban los siete ciclos planetarios; al subirlos, el sacerdote llegaba a la Cima del Universo",134.

\footnotetext{
${ }^{133}$ IMPELLUSO, Lucía. "La naturaleza y sus símbolos: plantas, flores y animales". Op.Cit. 2.003. Pág. 334.

${ }^{134}$ ELIADE, Mircea. “Imágenes y símbolos”. Op. Cit. Pág. 46. 


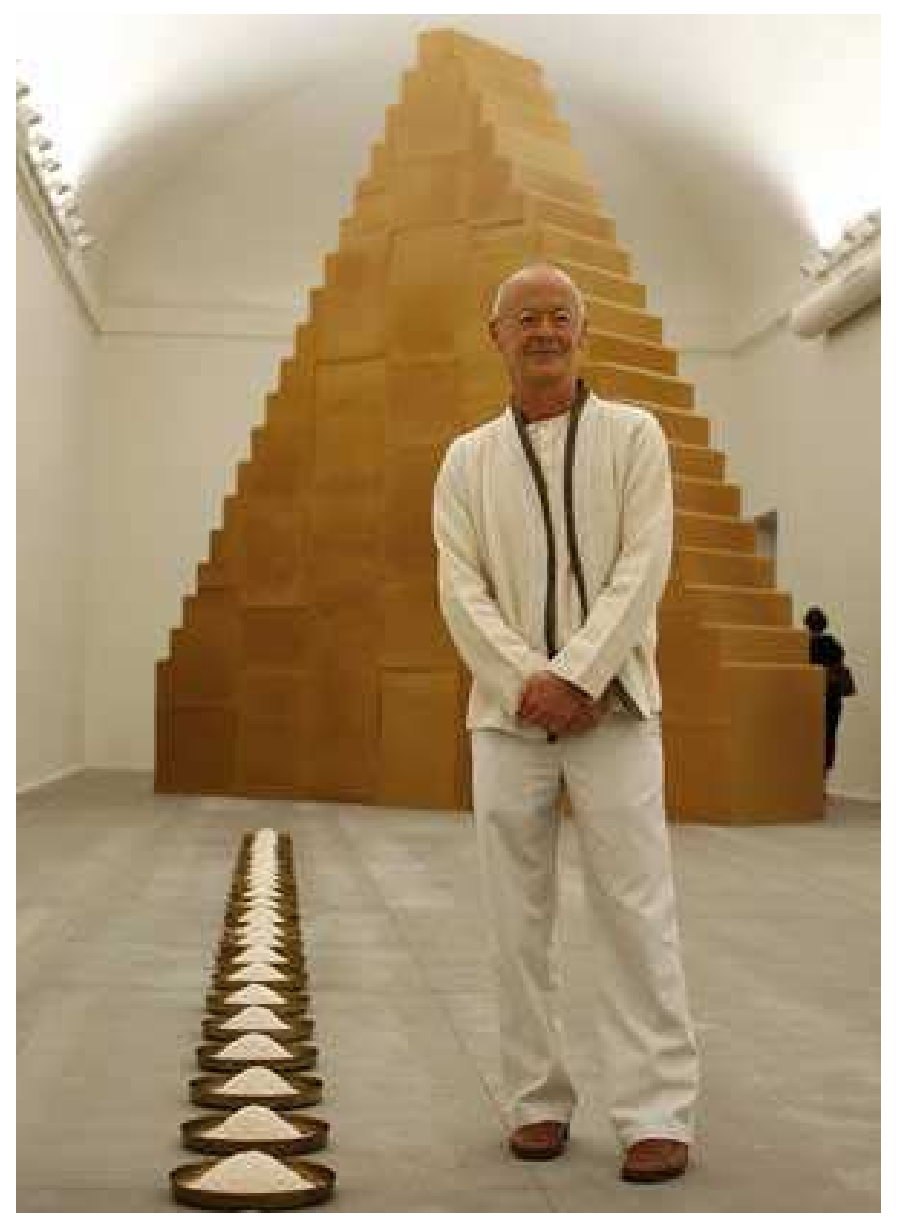

Ilustración 36. Wolfgang Laib posa junto a su obra, 'Nowhere-Everywhere'. (Foto: EFE)

Es una obra que impacta al espectador tanto por su fuerza visual como por su aroma. El olor nos acerca a la naturaleza, a la miel, al campo... el sentido del olfato muchas veces olvidado en temas artísticos donde lo visual suele ser lo predominante, nos transporta a otro lugar e incluso a otro tiempo, tal vez a alguna ensoñación o recuerdos de la infancia.

Los seres humanos siempre hemos valorado en gran medida a las abejas por su capacidad de crear la miel y la jalea real. Alimentos de un sabor agradable, energéticos y con cualidades curativas. Además se creía que la jalea era el alimento de los dioses, por tanto, era un alimento venerado y tomado en gran estima.

Otro elemento repetitivo en la obra del artista, es el polen. Wolfgang Laib le otorga al polen, un puesto especial en su trabajo, ya que es él personalmente quien lo recolecta en los campos cercanos a su casa y lo 
conserva en tarros de cristal, cuidadosamente cerrados y almacenados, para poder utilizarlos en sus obras posteriores. Es como un ritual que el artista realiza aproximadamente durante 30 años. Su simbología está unida a la fertilidad, a la creación, a la vida. Existe una conexión entre las abejas y el polen, ya que si éstas no polinizaran el planeta, la vida en él, desaparecería.

La mayoría de elementos empleados por el artista son a simple vista, de uso común y utilitario, no nos son desconocidos, pero tampoco somos capaces de producirlos. Ahí es donde reside la complejidad y el simbolismo de la obra.

- "Yo uso la leche y utilizo el polen o la cera de abeja, que yo no he creado. Participo en las cosas más bellas del mundo, que yo nunca podría crear". ${ }^{135}$

La leche representa el sustento vital de los seres vivos después de su nacimiento. Este líquido blanco nos alimenta, nos nutre y nos protege de las enfermedades. Nos conecta con su portadora y nos otorga bienestar y seguridad.

El mármol es un elemento sólido o líquido, recordemos la visión temporal de Giuseppe Penone. Es uno de los pocos materiales duraderos que el artista utiliza en sus obras. Es creado por la naturaleza y representa la majestuosidad, la fuerza... Es el contraste o complemento, según su visión, frente al resto de elementos utilizados.

Basta con realizar un estudio de su trabajo artístico para darse cuenta de que todas las experiencias de sus viajes y sus estudios sobre religión y misticismo, han quedado plasmadas en sus obras. Ellas se han convertido en el reflejo de sus pensamientos, emociones, sueños y manera de entender y comprender el mundo. El espectador se ve envuelto en esa visión y por unos instantes entra a formar parte de ella. Nos envuelve con su paz, su delicadeza, su elegancia, su simplicidad, su calma, nos otorga una ralentízación del tiempo, es una experiencia espiritual y mágica.

La dialéctica de su obra puede llegar a recordarnos algunas acciones de Joseph Beuys, donde la magia, la espiritualidad y el misticismo, estaban

\footnotetext{
${ }^{135}$ WOLFGANG, Laib entrevistado por SarahTanguy http://www.sculpture.org/documents/scmag01/may01/laib/laib.shtml

(10-07-2015 a las 16:36h) 
presente en ellas. Ambos artistas creen que el arte puede llegar a cambiar el mundo.

- "Kassel o Venecia me parecían oportunidades únicas, sobre todo cuando crees que el arte puede cambiar el mundo. Y por eso sigo queriendo hacer llegar mi trabajo al mayor número de receptores posibles. Me siento como un embajador. Después de esas citas, todo se precipitó. Sigo convencido de que la cultura y el arte pueden conseguir más cambios para el mundo que los que puede prometer un político". ${ }^{136}$

Pero por quien más se ha visto influenciado su trabajo es por el artista rumano, Brancusi. También estudió el taoísmo y a Laozi.

Unas de sus obras más conocidas y que mejor reflejan la visión de la prolongación del artista en ellas son: "Milkstore", "Rice Meals" y "Pollen from Hazelnut".

\footnotetext{
${ }^{136}$ Wolfgang Laib en una entrevista con Javier Díaz-Guardiola http://salonkritik.net/06-07/2007/04/ originalmente en abc.es $\quad(10 / 07 / 2015$ a las $16: 04 \mathrm{~h})$
} 


\subsection{1. “Piedra de leche” (“Milkstone”). Escultura creada en 1975.}

Fue uno de sus primeros trabajos y los materiales empleados para su creación fueron, el mármol y la leche.

El artista complementa lo sólido con lo líquido, lo duradero con lo efímero, creando una pieza de una delicadeza extrema donde el bloque de mármol nos otorga una visión completa de su estructura después de ser rellenada una hendidura provocada por Wolfgang Laib en la parte superior del bloque con leche.

La obra ubicada en el suelo, consta de un bloque plano y pulido de poco grosor que nos acerca al minimalismo, por su sencillez y sutileza visual, su blancura y virginidad. El espectador que contempla la obra, es testigo de una ilusión óptica, donde el bloque de mármol parece poseer una forma sólida gracias a la leche.

La pureza del color, su claridad, su delicadeza, su paz... conecta al espectador con la manera de sentir y vivir del artista. Es el reflejo de toda una vida atraído por la espiritualidad y el misticismo, es una parte de él, expuesta en un museo.

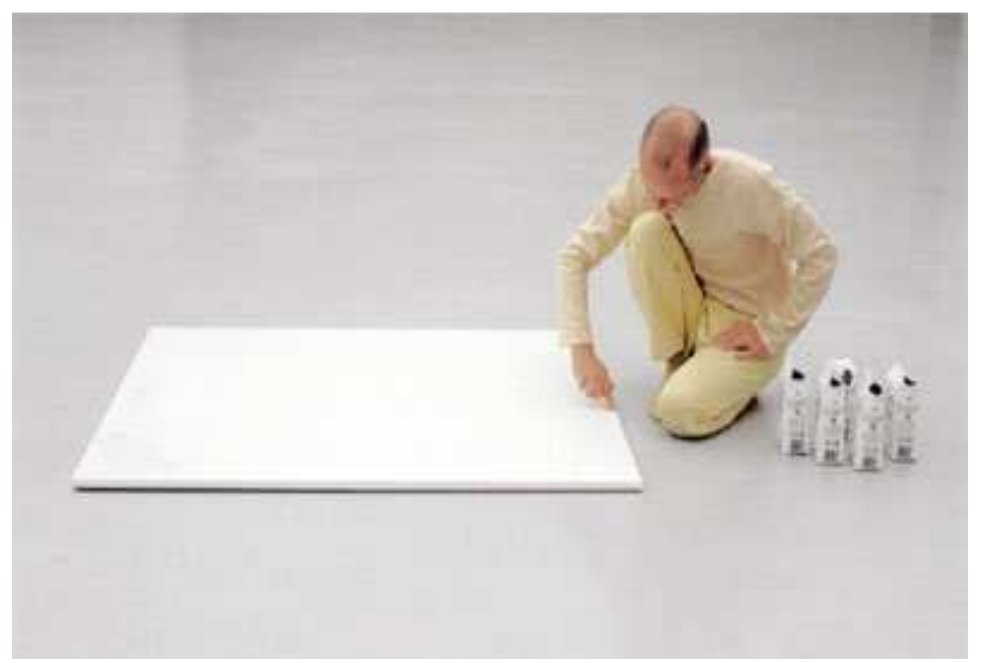

Ilustración 37. Proceso "Milkstone" ("Piedra de leche"). 


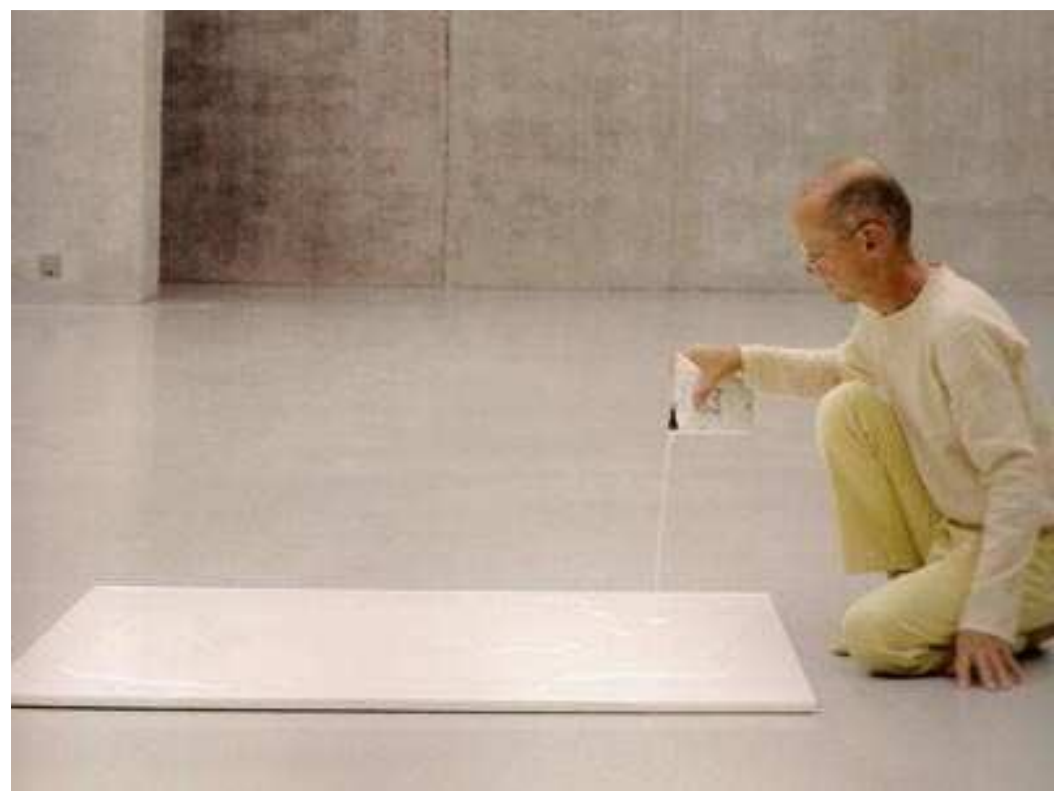

Ilustración 38. Milkstone, every day ritual

(Milkstone, ritual diario)

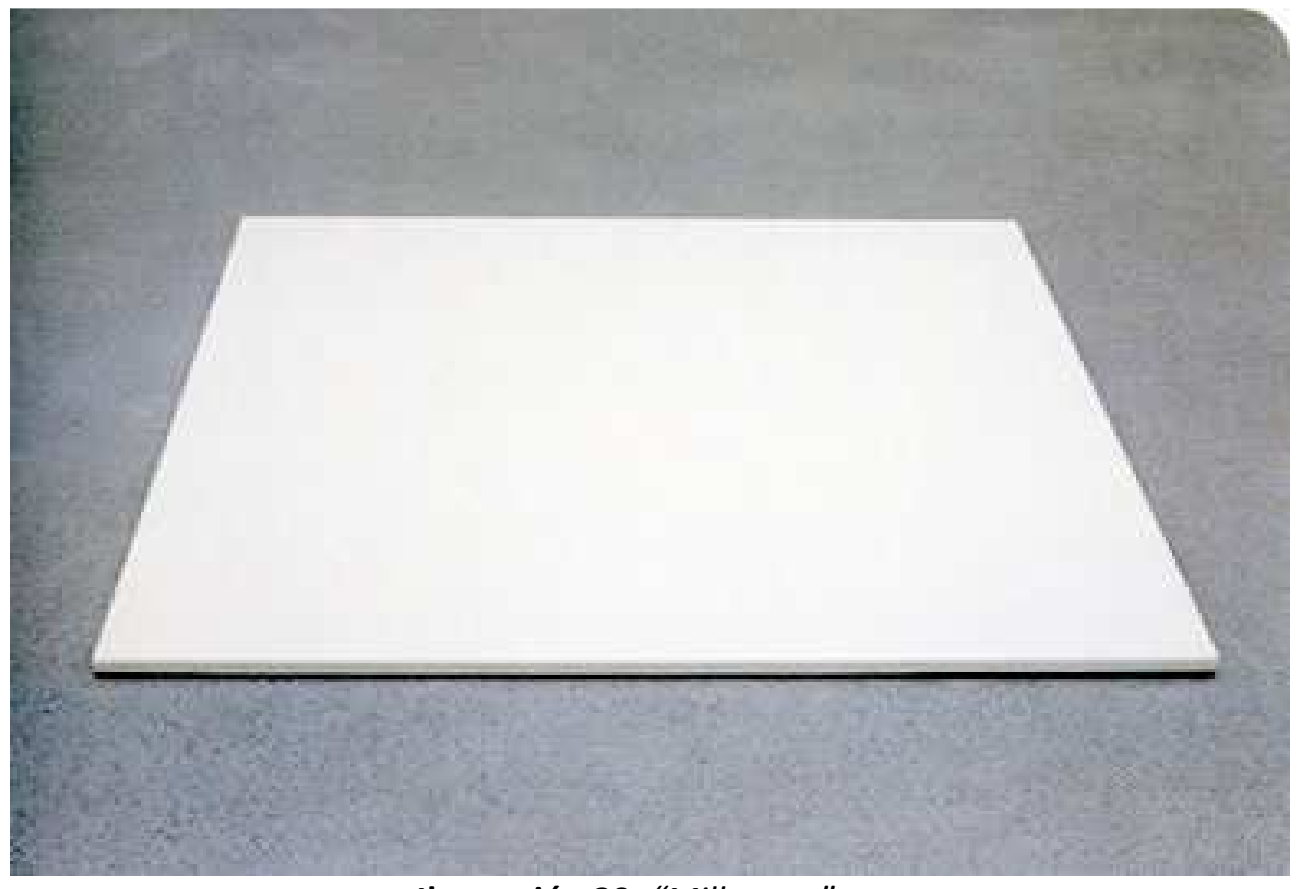

Ilustración 39. "Milkstone" 


\subsection{2. “Platos de arroz” (“Rice Meals”). Instalación creada en 1983.}

Su trabajo consta de 33 platos de latón "thali", colocados en fila y con una separación constante entre ellos, cada uno alberga una cantidad más o menos regular de arroz, creando una especie de camino de peregrinación.

Este alimento tiene una gran simbología en Oriente, pues en muchos países es la base principal de su alimentación, se le otorgan cualidades curativas tanto físicas como espirituales y es venerado y respetado.

Además los platos de latón, son utilizados en la India tanto para comer como para realizar ofrendas, con lo cual juega con la idea de lo sagrado, de la creencia, del rito, del culto... El lugar expositivo se convierte en un lugar de peregrinación, místico y espiritual, acercando al espectador a las costumbres, rituales, ofrendas... de las que el artista ha sido participe en sus viajes.

Es una conexión o acercamiento entre la cultura oriental y la occidental.

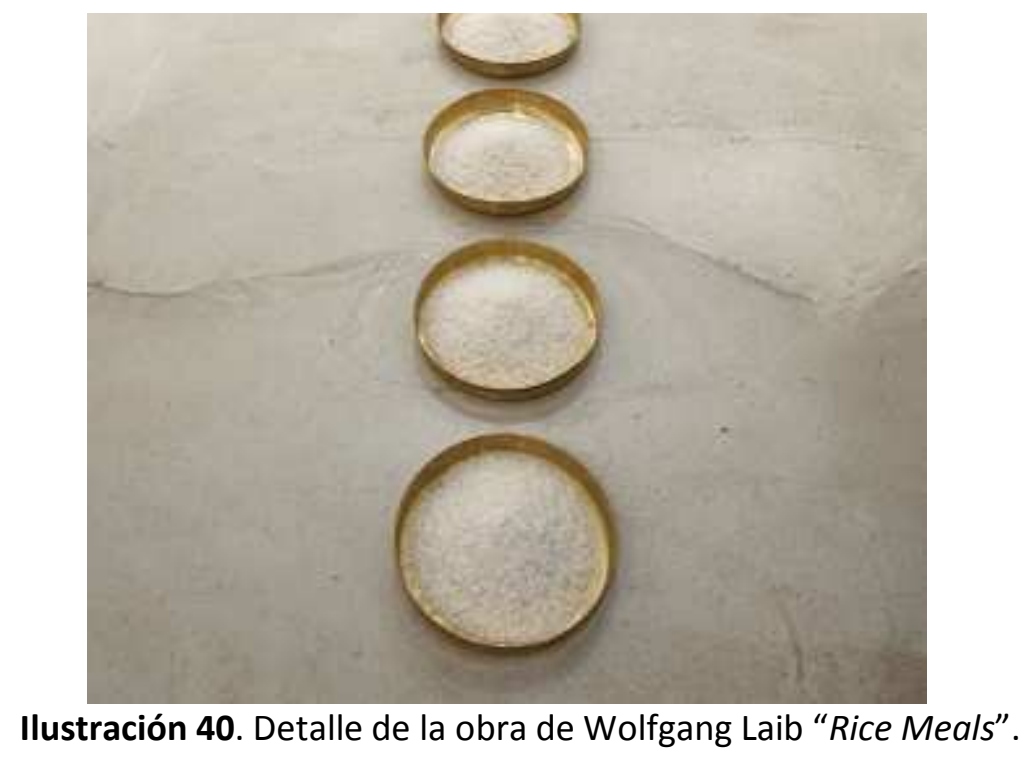




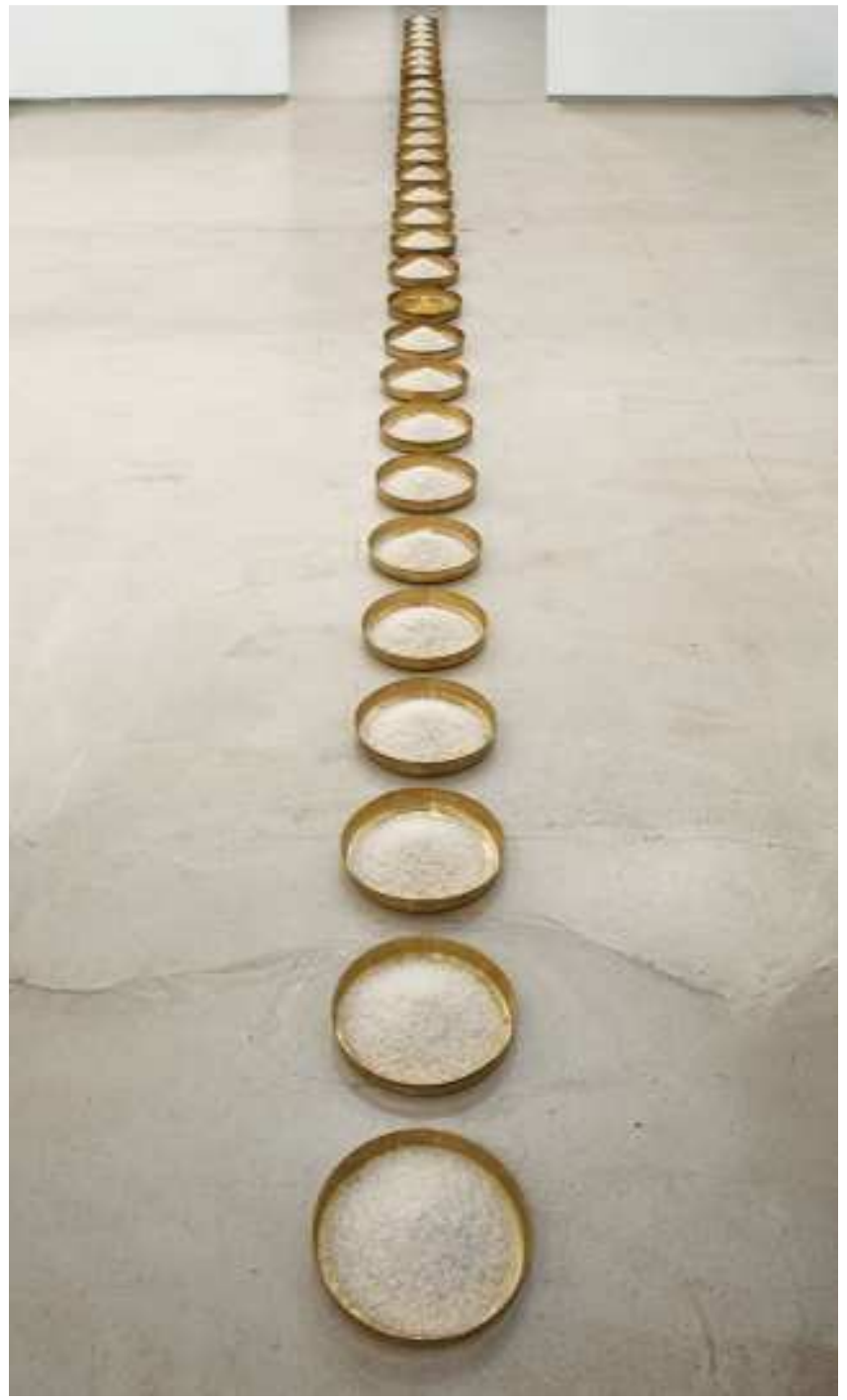

llustración 41. "Rice Meals" ("Platos de arroz") 


\subsection{3. "Polen de avellano" ("Pollen from Hazelnut").}

La instalación la compone un solo material, el polen.

En ella podemos ver cómo el artista se funde con su proyecto. Durante 30 años, ha repetido el ritual de recolectar él mismo el polen de los campos cercanos a su residencia, conservándolos en tarros de cristal desde la primavera-verano hasta su utilización, es un acto cíclico que repite año tras año. En este caso concreto, el material utilizado para crear un cuadrado en el suelo es, polen de avellano.

Una vez el artista necesita del polen almacenado con tanto mimo y cuidado, es colocado directamente sobre el lugar expositivo mediante un colador y una cuchara para facilitar su cribado. No hay más herramientas que las nombradas y la paciencia, el tiempo y la calma del artista. Como si de un acto sagrado, ofrenda o ritual se tratara, Wolfgang Laib va llenado el espacio expositivo de una manera constante pero pausada. Es como si el tiempo se ralentizara, no existen las prisas, ni los agobios, es un momento de paz, de meditación, donde todos sus sentidos están puestos en ese movimiento que se repite una y otra vez que es ver caer el polen, llenando el espacio de un color amarillo intenso.

Esta obra, aunque minimalista, está cargada de simbología, de vida.

El espectador la percibe en todo su esplendor, es como si parte de la naturaleza, de la primavera se hubiera ubicado en la galería o museo donde se encuentra, tanto por su colorido como por su aroma. 


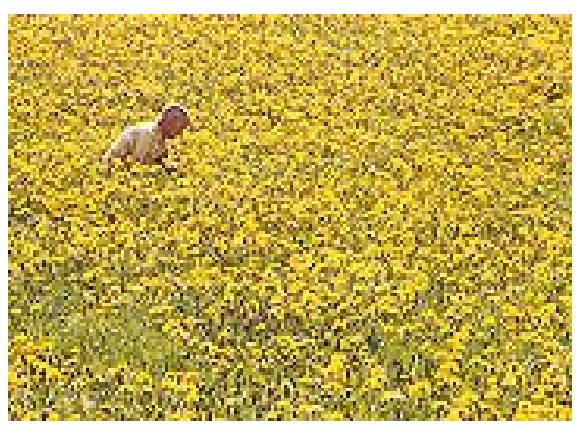

Ilustración 42. Recolección de polen por Wolfgang Laib.

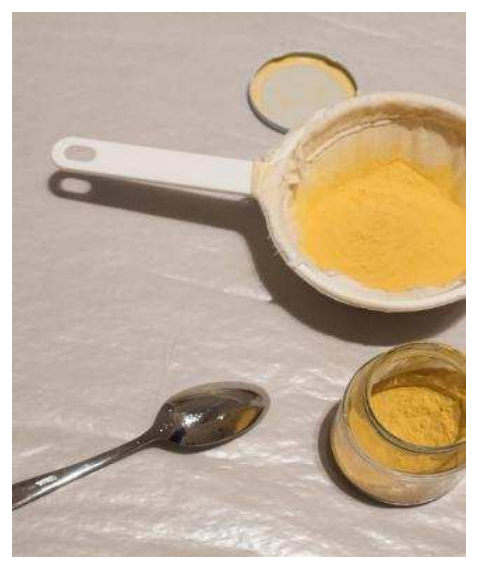

Ilustración 43. Materiales de trabajo.

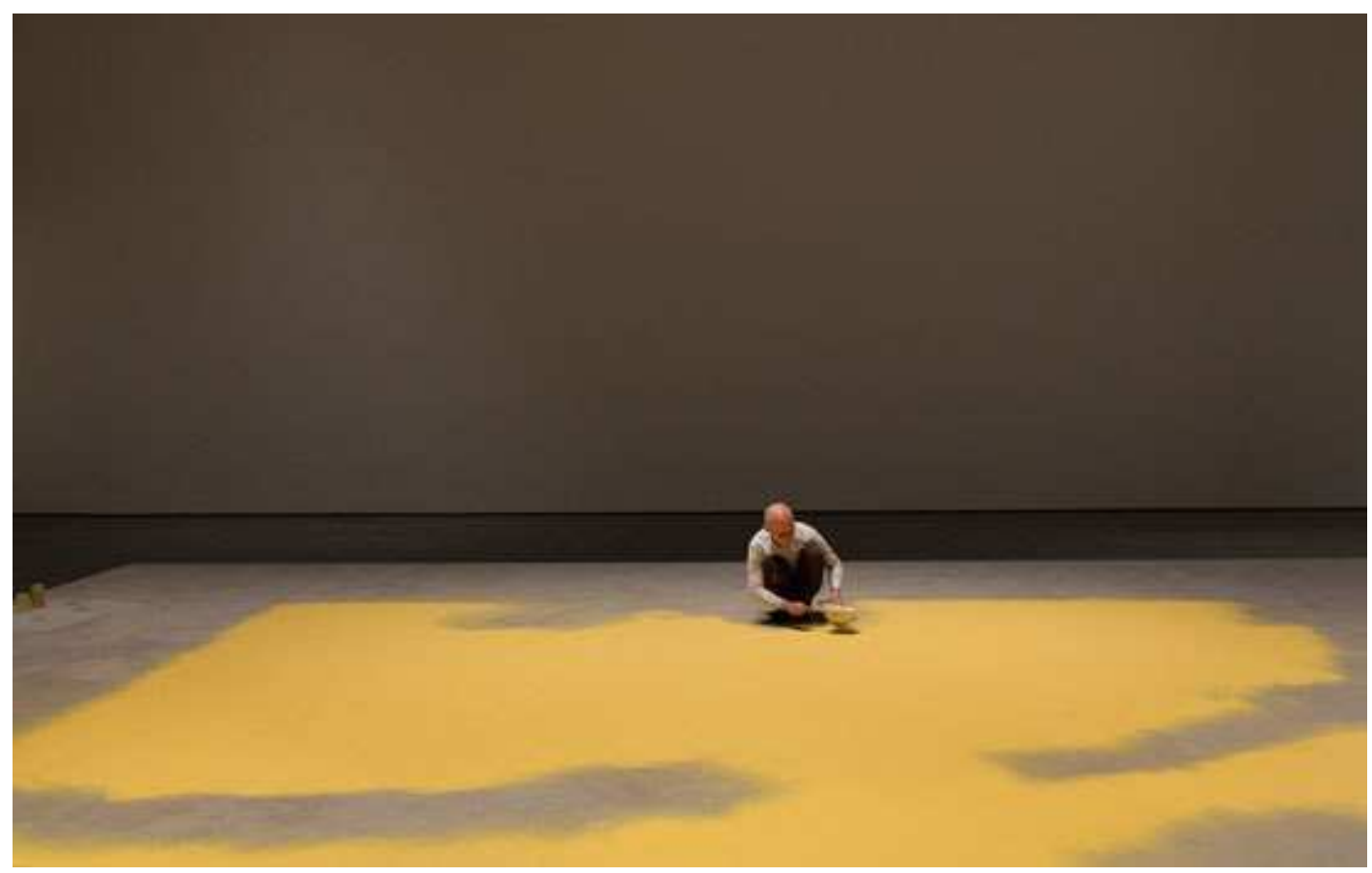

Ilustración 44. Wolfgang Laib instalando su trabajo "Pollen from Hazelnut" en el MOMA. 2013 


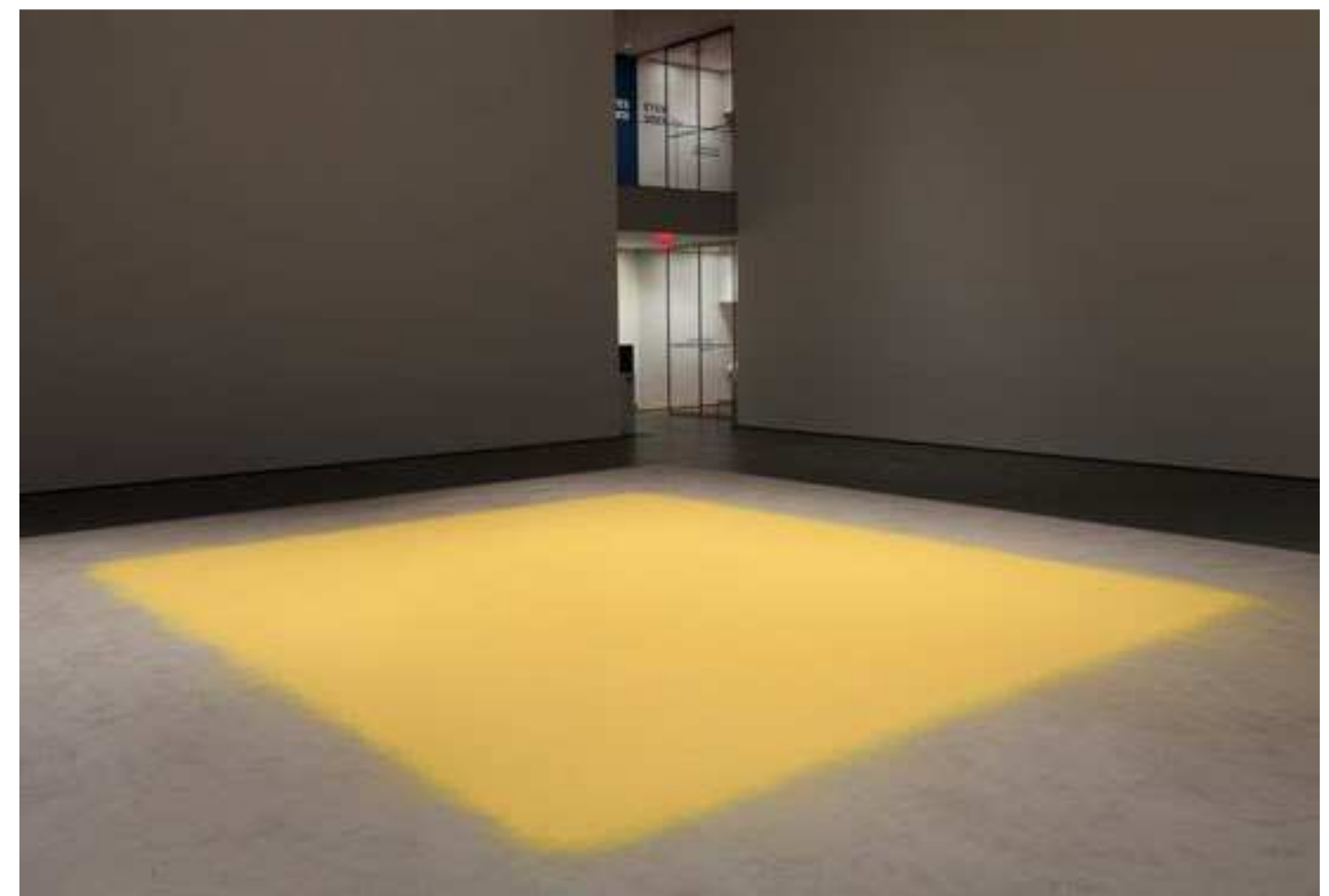

Ilustración 45. "Pollen from Hazelnut" en el MOMA. 2013 
4.3.4. “Cámara de cera” ("Wax Chamber”), creada por primera vez en 1988.

Sus cámaras de cera, son como indica el título, habitaciones donde todas las paredes están cubiertas de láminas de cera de abeja. El habitáculo de un color amarillo intenso, sólo posee una bombilla en el techo, y su olor es penetrante, reavivando los sentidos del espectador acercándole a la naturaleza. La mezcla y la aplicación de este material lo realiza el artista con una espátula, asegurándose por medio de una fuente de calor que todo esté en orden y las paredes queden sujetas. La acción es similar a la que realiza en su obra anterior, donde hay una especie de ritual a la hora de aplicar la cera y trabajarla. El tiempo no importa, es un trabajo de esfuerzo, de laboriosidad, casi podíamos decir que, existe una similitud entre el trabajo y ser del artista y el animal que crea la cera, la abeja. Con este material Wolfgang Laib está creando un lugar de protección, de aislamiento, de bienestar, hace las veces de lugar espiritual, sagrado, de culto y de meditación. Se podría decir que simboliza el poder de la cueva para el hombre primitivo o la crisálida para la oruga.

Ha creado un lugar atemporal donde escapar de la velocidad de la sociedad actual, es un presente permanente. Lugar de paz, de relajación y a su vez claustrofóbico, encerrado, aislado.

Estas habitaciones de cera, se van adaptando conforme al espacio expositivo de los museos y las galerías, creándose en espacios a veces tan reducidos que la sensación de entrar debe de ser como estar envuelto en cera, podríamos decir que, es como estar enterrado en vida. 


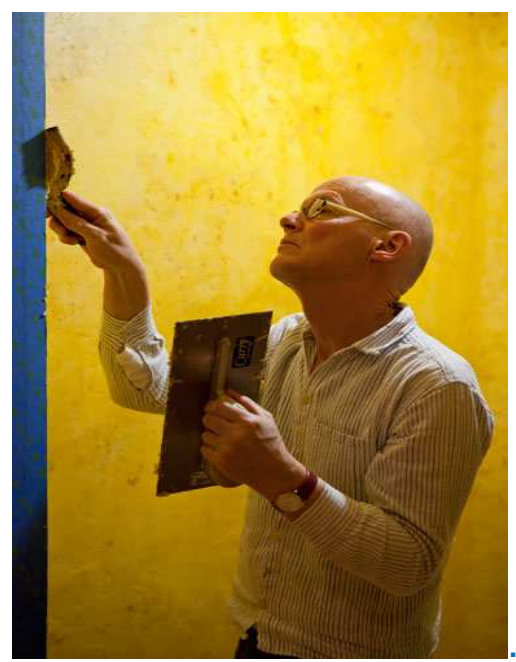

llustración 46. Wolfgang Laib instalando la "Habitación de cera". Photo by Rhiannon Newman.

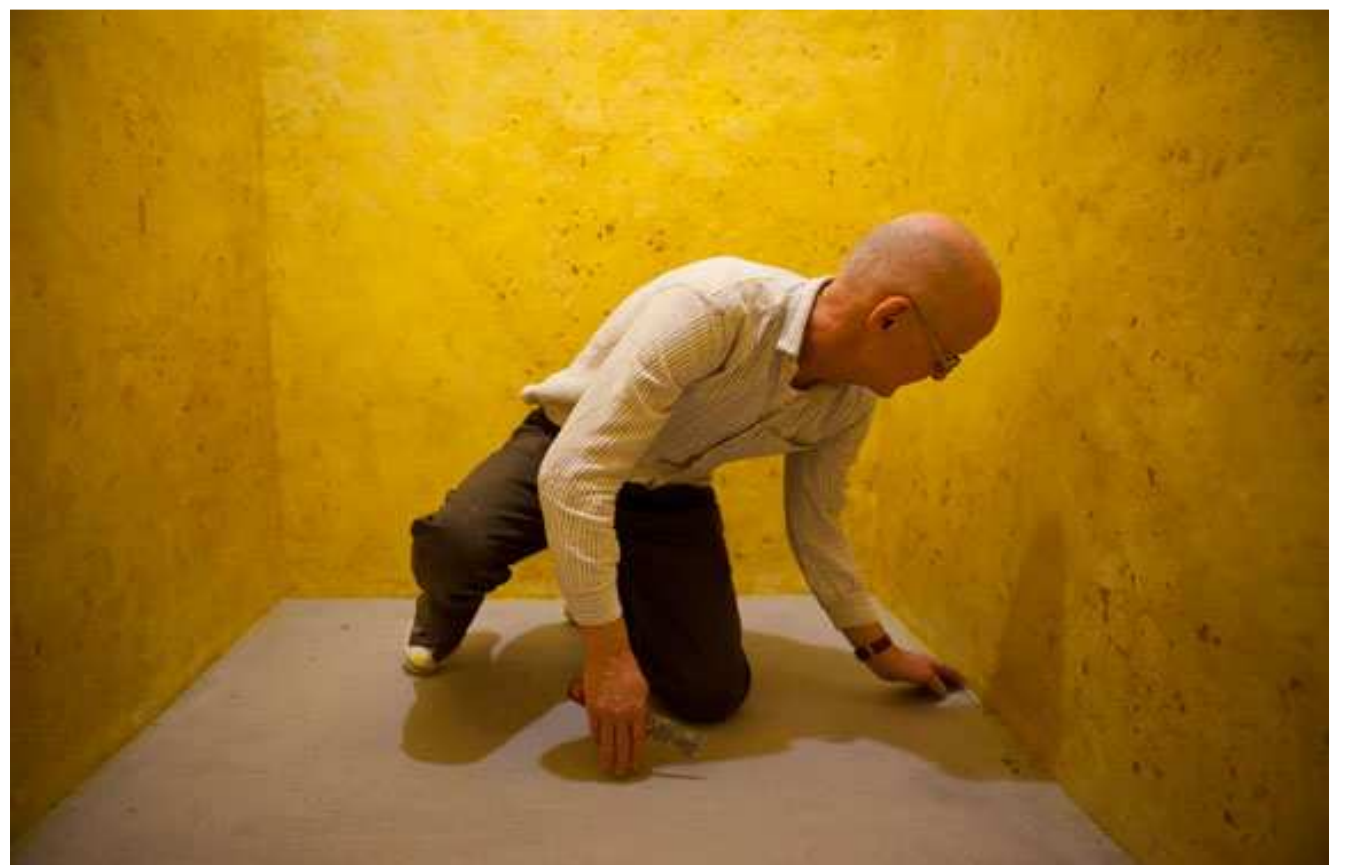

Ilustración 47. W. Laib utiliza una plancha caliente, cuchillos y espátulas para trabajar la cera de abejas. Foto por Rhiannon Newman. 
Toda su obra es el reflejo de todas las vivencias, creencias, religiones, cultos, rituales, emociones que el artista ha aprendido, visto, experimentado y estudiado a lo largo de su vida. Pero no son fragmentos aislados e individuales colocados en una galería o un museo, representan a nivel global y son, toda una vida dedicada a la espiritualidad y al estudio de diferentes culturas y religiones, poseen la energía del artista, su calor, su delicadeza, su paz y armonía.

Como hemos podido comprobar su trabajo está cargado de misticismo, es la unión de lo efímero y lo duradero, lo sólido y lo líquido, Oriente y Occidente... Sus instalaciones acercan al espectador a lo aprendido y vivido por el artista en sus frecuentes viajes y esto lo consigue creando lugares de culto, sagrados, de meditación, místicos, simbólicos, libres de presiones, de competiciones, donde el tiempo adquiere una nueva dimensión, ya no existen las prisas, el tiempo se detiene y nos acerca a un momento presente en el que todos nuestros sentidos están fijos en él, no existe el pasado ni en el futuro, contemplando su obra, somos sólo presente. 

5. Metamorfosis en el proceso creativo: una comparación poética entre el ciclo vital de la mariposa y el proceso de fundición artística a la cera perdida. 
Una vez hemos tratado el tema del hombre como una especie más de la naturaleza, el arte como camino para expresar las emociones, ideales y sentimientos del artista (capaz incluso de cambiar el mundo), de intentar desarrollar la idea de que la obra de arte es por tanto, la prolongación del artista y en ella además de su impronta, su fuerza y energía, también están las vivencias y creencias del autor, que con cada obra abre una ventana a su verdadero ser y deja que el espectador por unos instantes pueda ser testigo de su realidad más íntima. Damos un paso más hacia la conexión entre la naturaleza y el arte, creando una comparación poética e imaginativa entre un proceso natural como es el ciclo vital de la mariposa y un proceso artístico como es el proceso de fundición artística a la cera perdida, pues los procesos artísticos se convierten por tanto, en la vía de conexión y comunicación entre la obra de arte y su creador. Al ser estas una prolongación del artista y estar dotadas de vida, los procesos elegidos para realizarlas también se convertirán en procesos naturales, pudiéndose llevar a cabo esta comparativa. Para ello, estudiaremos los materias principales en el proceso de fundición artística a la cera perdida: el fuego, la cera y el metal.

Explicaremos a grandes rasgos ambos procesos por separado para después, obtener una mejor comprensión global. 
5.1. El ciclo vital de la mariposa 
La mariposa es un ser de una belleza extraordinaria, delicada y frágil, que ha inspirado a grandes artistas en todos los géneros. Nadie queda indiferente ante su aleteo, sus coloridos y su elegancia.

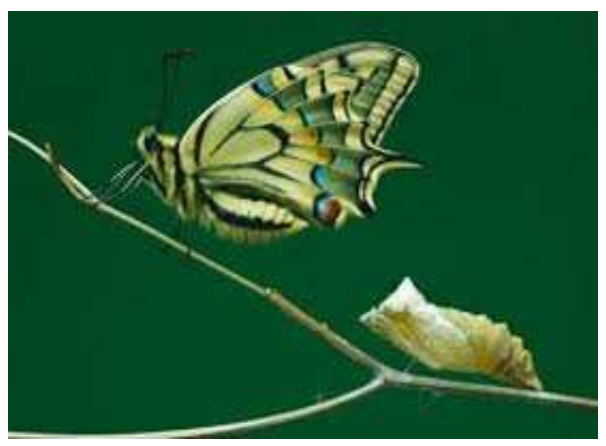

"Cuando nace una mariposa, si eso se puede llamar nacer, no puede ser más que una princesa, tal vez por realizar un sueño, o tal vez por surgir de una transformación que sólo puede ser producto de la imaginación del mejor escritor de cuentos infantiles". ${ }^{137}$

Ilustración 48. Imago recién emergido de Papilio machaon.

Gabino Marín

Los insectos son los animales más numerosos; las polillas y las mariposas pertenecen a este grupo. Podemos dividirlas en dos grupos; diurnas y nocturnas, pero ambas reciben el nombre de Lepidópteros.

- "Una buena definición de mariposa podría ser la de un insecto, con alas cubiertas de escamas y con un ciclo biológico que requiere de una metamorfosis para llegar a adulto". ${ }^{138}$

Según David Carter las mariposas diurnas se reconocen por sus colores brillantes y sus peculiares antenas en forma de maza, aunque también por su posición de descanso, con las alas verticales y juntas. La base de sus alas posteriores es fuerte $y$ ancha, a fin de soportar y acoplarse con las anteriores durante el vuelo. Las mariposas nocturnas "polillas", son tan diversas que es difícil dar de ellas una descripción general. Suelen distinguirse por sus antenas plumosas o filamentosas, cuyos extremos adolecen las "mazas". 139

Desde su aparición en el mundo, las mariposas han sufrido una evolución al igual que el hombre y resto de seres vivos del planeta. Han demostrado que bajo su aspecto frágil y delicado hay un ser fuerte con

\footnotetext{
${ }^{137}$ CÓRDOBA LEÓN, Juan ramón; SESMA MORANAS, José Manuel y MARTín TORAL, Gabino. “Mariposas en libertad". Ediciones Publimarca. Madrid, 2.006. Pág. 4.

${ }^{138}$ CÓRDOBA LEON, Juan ramón; SESMA MORANAS, José Manuel y MARTín TORAL, Gabino. "Mariposas en libertad". Op. Cit. Pág. 35.

${ }^{139}$ CARTER, David. "Mariposas diurnas y nocturnas". Ediciones Omega. Barcelona, 1993. Págs. 10 y 11. 
capacidad para adaptarse a cualquier clima y por ello, las podemos encontrar en cualquier parte del planeta.

Los principales enemigos de las mariposas además de las inclemencias del tiempo somos los seres humanos, porque en ocasiones devastamos los territorios donde ellas habitan llevando a la extinción a especies enteras.

También son un manjar exquisito para arañas, hormigas, avispas, ranas, lagartijas... y para su supervivencia sólo poseen algunas estrategias defensivas como; los colores advertidores, el mimetismo y los ocelos.

Las orugas al igual que las mariposas poseen varios mecanismos de defensa: puestas muy abundantes, puestas muy separadas y orugas crípticas difíciles de ver.

Con la puesta masiva de huevos en un mismo lugar, se busca la supervivencia de algunas orugas ante el ataque de los depredadores. Con la puesta muy separada, se pretende que los depredadores debido a la escasez de alimento no pierdan tiempo buscándolas.

En cuanto a las orugas, algunas poseen aspecto amenazador para evitar ser atacadas. También son capaces de mimetizarse con el entorno.

De todos modos, sólo una mínima parte de las orugas que nacen llega a convertirse en adultos. Si lo consiguen, habrán culminado un proceso en el que todos sus tejidos habrán desaparecido dejando paso a otros nuevos, durante la fase de metamorfosis. Por tanto, la mariposa que emerge de la crisálida nada tiene que ver con la oruga que creó ese espacio protector. La misión de la oruga es alimentarse para crecer y crear la crisálida o pupa que dará paso a la transformación en mariposa. La función de la mariposa es reproductora, una vez puestos los huevos éstas se mueren dejando paso a su congénere.

Como hemos podido apreciar, el ciclo vital de la mariposa consta de cuatro fases diferenciadas que son; el huevo, la oruga o larva, la crisálida o pupa y la mariposa o imago.

Tanto en la primera como en la tercera fase no habrá movilidad, aunque el ser si sufra alteraciones y cambios. Por el contrario, la segunda y cuarta fase es activa y móvil. 


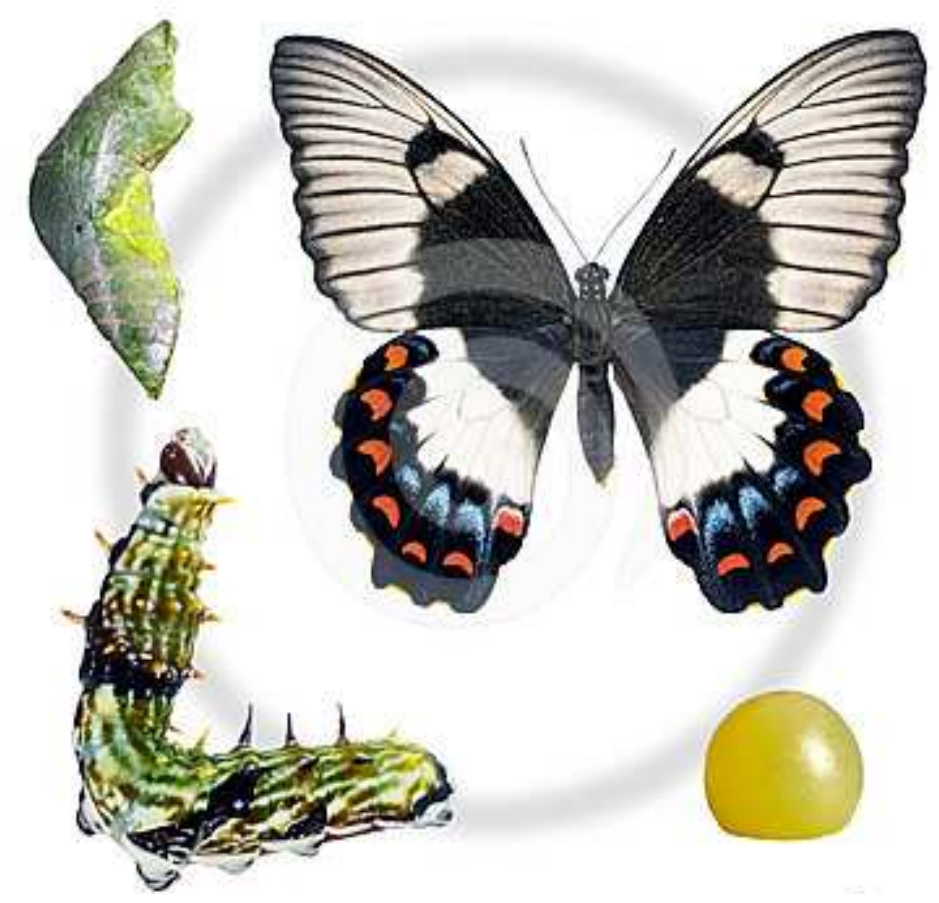

Ilustración 49. Las fases del ciclo vital de la mariposa. 


\section{El huevo.}

Es la primera fase del ciclo vital de la mariposa. Es un periodo inactivo o inmóvil. El embrión-oruga se desarrolla con la información genética de sus progenitores dentro de una envoltura protectora que es blanda y blanquecina en el momento de la puesta, pero que se va endureciendo, variando su color, textura y forma con el paso del tiempo.

Como explica en su libro Ivo Novák:

- "La superficie exterior puede ser más o menos suave o rugosa, toscamente esculpida con crestas y huecos o estar decorada con manchas irregulares. La forma del huevo demuestra una gran diversidad y puede ser esférica, cónica, cilíndrica, con forma de barra, bote o huso, angular o plana y tipo escama. El corion tiene un orificio diminuto llamado micrópilo a través del cual penetra el esperma móvil para alcanzar el gameto femenino y fertilizarlo. El micrópilo puede estar situado en la zona superior del huevo, y el huevo se llama huevo vertical, o puede estar situado lateralmente, en cuyo caso se denomina yacente. (...) A veces, la coloración puede cambiar con el desarrollo del embrión. Los huevos pálidos pueden adquirir marcas rojizas; otras veces toman colores más oscuros como pardo y violeta. En huevos con cáscara fina y translúcida es posible ver hacia el final del desarrollo embrionario la cabeza de la oruga a través del corion". ${ }^{140}$

El lugar escogido por las mariposas para colocar los huevos varía: hojas, ramas, troncos, tallos, flores... pero casi todas lo hacen sobre una planta que al nacer pueda otorgarle a la oruga los nutrientes necesarios para su supervivencia, pues hay mariposas que sobreviven gracias al alimento ingerido en su estado oruga.

Los huevos se ven afectados por factores externos como la luz, la temperatura y la humedad. En el momento de la eclosión, la luz jugará un papel importantísimo porque el embrión-oruga se regirá por ella para decidir cuándo es el momento idóneo para salir del huevo.

\footnotetext{
${ }^{140}$ NOVÁK, Ivo. “Mariposas". Ed. Susaeta. Madrid, 1.990. Pág. 8.
} 


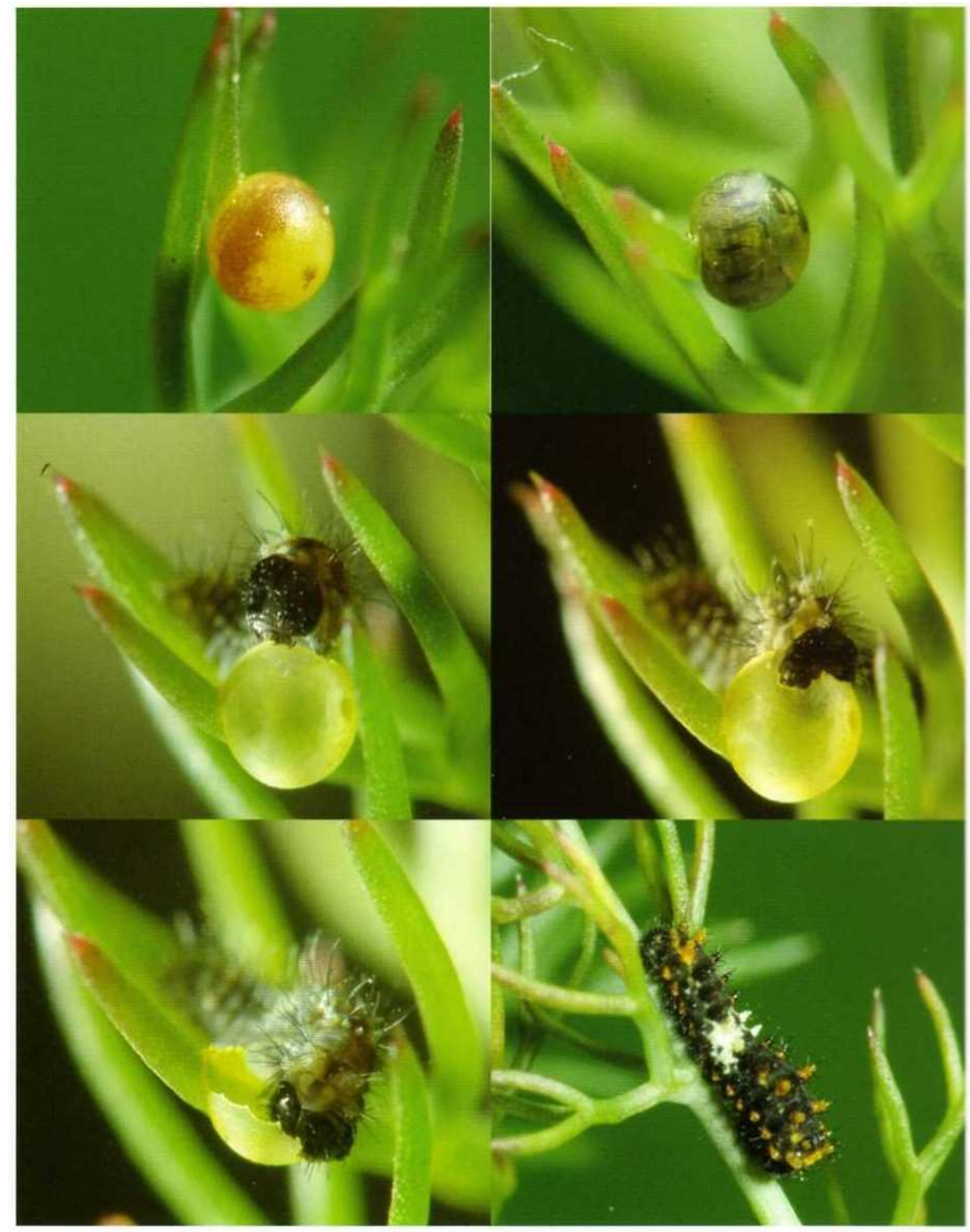

Ilustración 50. Nacimiento de Papilio machaon. 


\section{La oruga.}

Es la segunda fase del ciclo vital de la mariposa y es una fase móvil y activa. En ella, la oruga crece y se desarrolla hasta estar preparada para realizar la crisálida donde se transformará en mariposa. Por tanto, su única función en este periodo es nutrirse, evitar ser devorada, no enfermarse y sobrevivir a las condiciones climáticas y a los cambios estacionales.

Para ello, la oruga debe de comenzar su alimentación devorando el huevo vacío o corión del que ha eclosionado. A partir de este momento como bien menciona Ivo Novák, la oruga debe comenzar la búsqueda de los alimentos específicos que componen su dieta, ya sean hojas verdes, yemas, raíces, bulbos, madera o cualquier otra cosa. Algunas orugas roen diferentes semillas, manzanas, nueces, bellotas y otros frutos. Otras se alimentan de materia derivada de otros animales, como plumas, pelos, cera de abejas y hasta carne de animales muertos. En su hábitat natural estas orugas viven en nidos de pájaros o madrigueras de mamíferos (...) Existen también orugas depredadoras que o bien devoran a las de su propia clase (un ejemplo de canibalismo) o a otras orugas y animales ${ }^{141}$.

Como su única función es nutrirse, su cuerpo posee una forma cilíndrica idónea para este fin. Está dividido en trece segmentos y tres de ellos, poseen unas patas articuladas con uñas que le sirven para sujetar la comida y el resto posee patas que utiliza para sujetarse a la planta en la que se encuentra. Además su piel está preparada para realizar diversos cambios para no obstaculizar su crecimiento. Tiene unas mandíbulas fuertes con las que es capaz de triturar los alimentos que ingiere y una glándula que produce hebras de seda que podrá utilizar tanto para hacer la crisálida o pupa como para dejarse transportar por el viento.

\footnotetext{
${ }^{141}$ NOVÁK, Ivo. "Mariposas". Op. Cit. Pág. 9.
} 


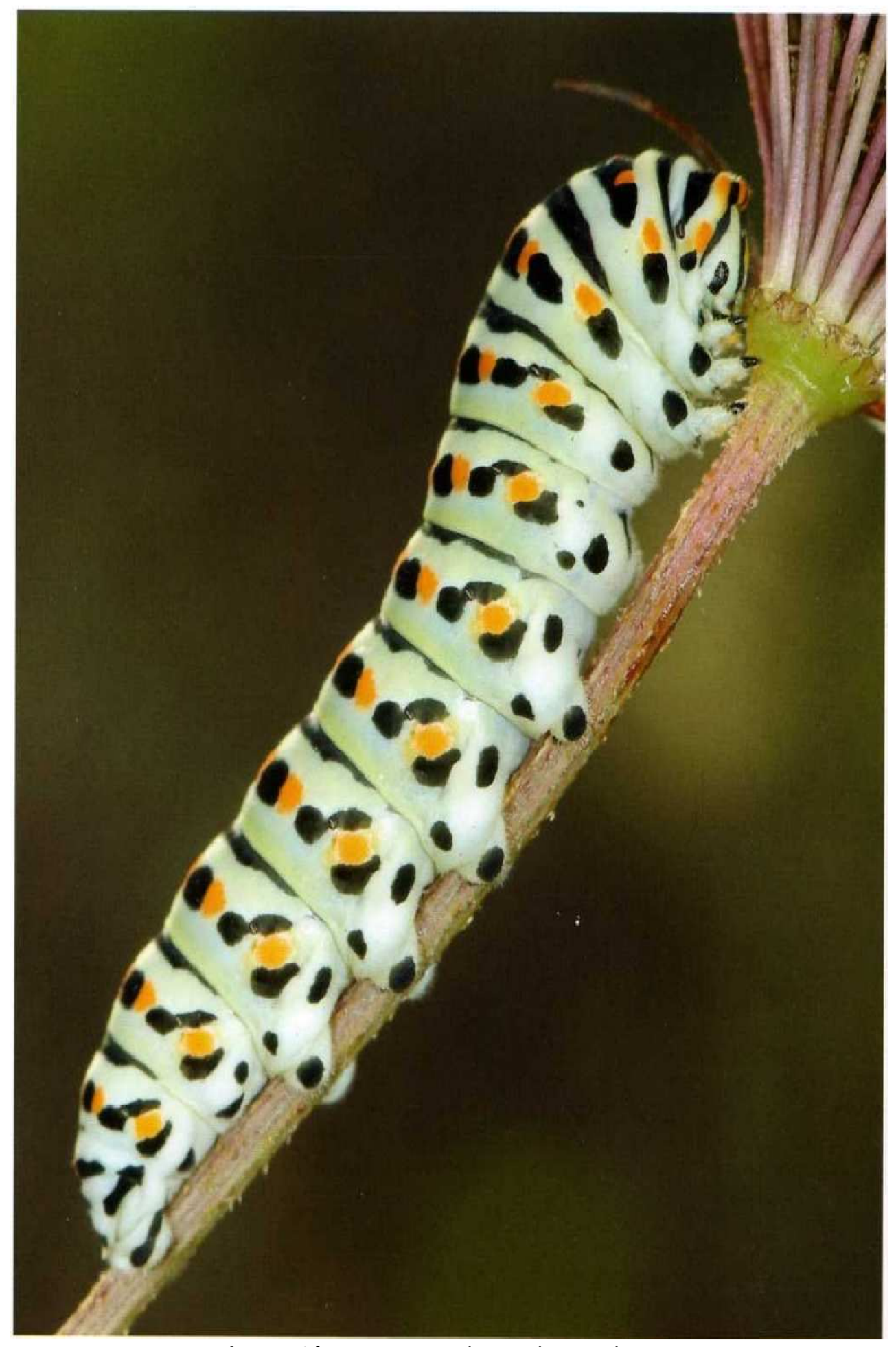

Ilustración 51. Oruga de Papilio machaon. 


\section{La crisálida o pupa.}

Es la tercera fase del ciclo vital de la mariposa y es un periodo inactivo porque no hay ingesta de alimentos por parte de la oruga, pero a su vez es una fase de transformación y cambio, pues en el interior de la crisálida se da uno de los procesos más complejos de la naturaleza: la metamorfosis.

Todos los tejidos de la oruga desaparecerán por completo dejando paso a otros nuevos. Es una transformación total.

La oruga busca el lugar idóneo para realizar su crisálida, pero a pesar de su esfuerzo, ésta es una etapa muy vulnerable en su ciclo vital. Son muchos los depredadores que intentarán atacarlas en esta fase, aunque las crisálidas también poseen armas de defensa ante sus atacantes, tal y como nos narra David Carter:

- "Aunque las pupas tienen cáscaras protectoras duras, no dejan de ser vulnerables a los pájaros, ratones y otras criaturas que las consideran bocados sabrosos. Al igual que las orugas, muchas aseguran su protección confundiéndose con el entorno; algunas son incluso capaces de cambiar de color para asimilarse a la superficie sobre la que descansan. Otras parecen hojas muertas o trozos de ramitas, mientras que las pupas venenosas suelen ser bastante conspicuas y de colores brillantes. Las pupas de diversas polillas se forman en el interior de un envoltorio protector de seda o capullo". ${ }^{142}$

Por tanto, al igual que ocurría con las orugas, las crisálidas o pupas utilizan ciertas estrategias defensivas ante sus depredadores porque no hay que olvidar que en ocasiones los periodos de metamorfosis son cortos, pero otras veces pueden durar varios años.

\footnotetext{
${ }^{142}$ CARTER, David. “Mariposas diurnas y nocturnas”. Op. Cit. Pág. 15.
} 


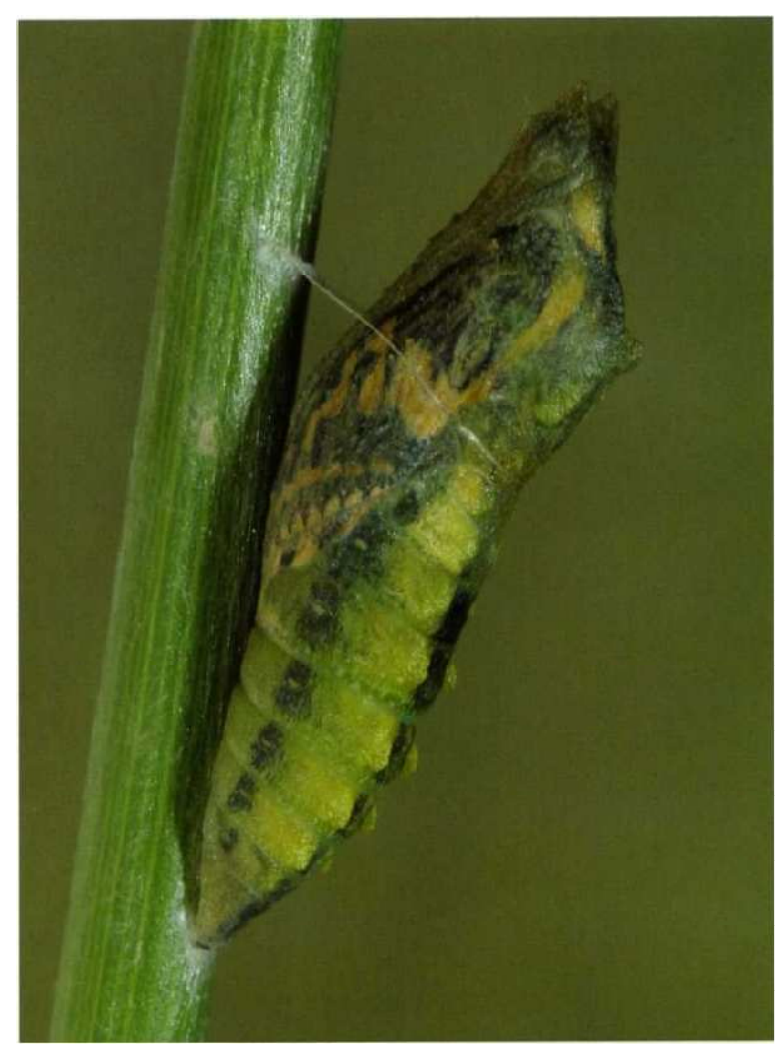

Ilustración 52. Crisálida de Papilio machaon. 


\section{La mariposa o imago.}

Es la última fase del ciclo vital de la mariposa. Es el momento en el que la mariposa emerge de su crisálida. Lo hace en cuestión de segundos, debido a que la mariposa colgada boca abajo debe abrir sus alas nada más salir de la crisálida para que se le sequen y evitar así, posibles deformaciones permanentes.

Como cualquier otro insecto su cuerpo está dividido en tres partes; cabeza, tórax y abdomen. Carecen de esqueleto interno pero tienen la parte exterior de su estructura endurecida. Poseen sentidos, antenas, grandes ojos y algunas especies una trompa larga y gruesa para absorber el néctar de las flores y la humedad del suelo. Tres segmentos forman el tórax y en cada uno hay insertadas un par de patas y en los posteriores un par de alas. Las alas son la parte que más llama la atención de estos insectos por su colorido y bellos dibujos.

\section{"Las mariposas y sus alas"}

Nos fascinan porque su vuelo es sutil, porque sus coloridas alas nos atraen, porque pensamos que son frágiles y etéreas, apenas hechas de papel. Nos llama la atención su silenciosa existencia. Su presencia nos alegra cuando irrumpen en primavera entre las flores silvestres recién abiertas y sentimos que la vida renace. El movimiento de sus alas es incapaz de perturbar la calma que sin darnos cuenta sentimos.

Pero difícilmente tenemos posibilidad de acercarnos a ellas. Son huidizas, algunas excesivamente pequeñas para poder admirar sus colores, para completar sus formas.

Son muchas, tan iguales y a la vez tan diferentes, $y$ lo más sorprendente es que están entre nosotros". ${ }^{143}$

\footnotetext{
${ }^{143}$ CÓRDOBA LEÓN, Juan Ramón; SESMA MORANAS, José Manuel y MARTín TORAL, Gabino. “Mariposas en libertad ". Op. Cit. Pág 1.
} 
El color, la forma, el dibujo y el tamaño de sus alas varía de unas especies a otras. También depende de si las mariposas son diurnas 0 nocturnas.

El colorido de sus alas se debe a que están recubiertas de escamas solapadas y éstas, pueden estar pigmentadas o producir colores físicamente por difracción y refracción de la luz.

El colorido y dibujo de sus alas le sirve a la mariposa como arma de defensa ante sus depredadores utilizándolas como camuflaje para confundirse con el entorno o mimetizando a las especies venenosas para engañar a sus enemigos.

La mariposa debe de mantenerse con vida para realizar la única misión que posee que es, la reproducción y la posterior puesta de huevos. El macho muere después de aparearse con la hembra, y ésta lo hace una vez ha fecundado los huevos y ha realizado su puesta en un lugar seguro.

Con esta nueva puesta de huevos, vuelve a repetirse este maravilloso ciclo vital. 


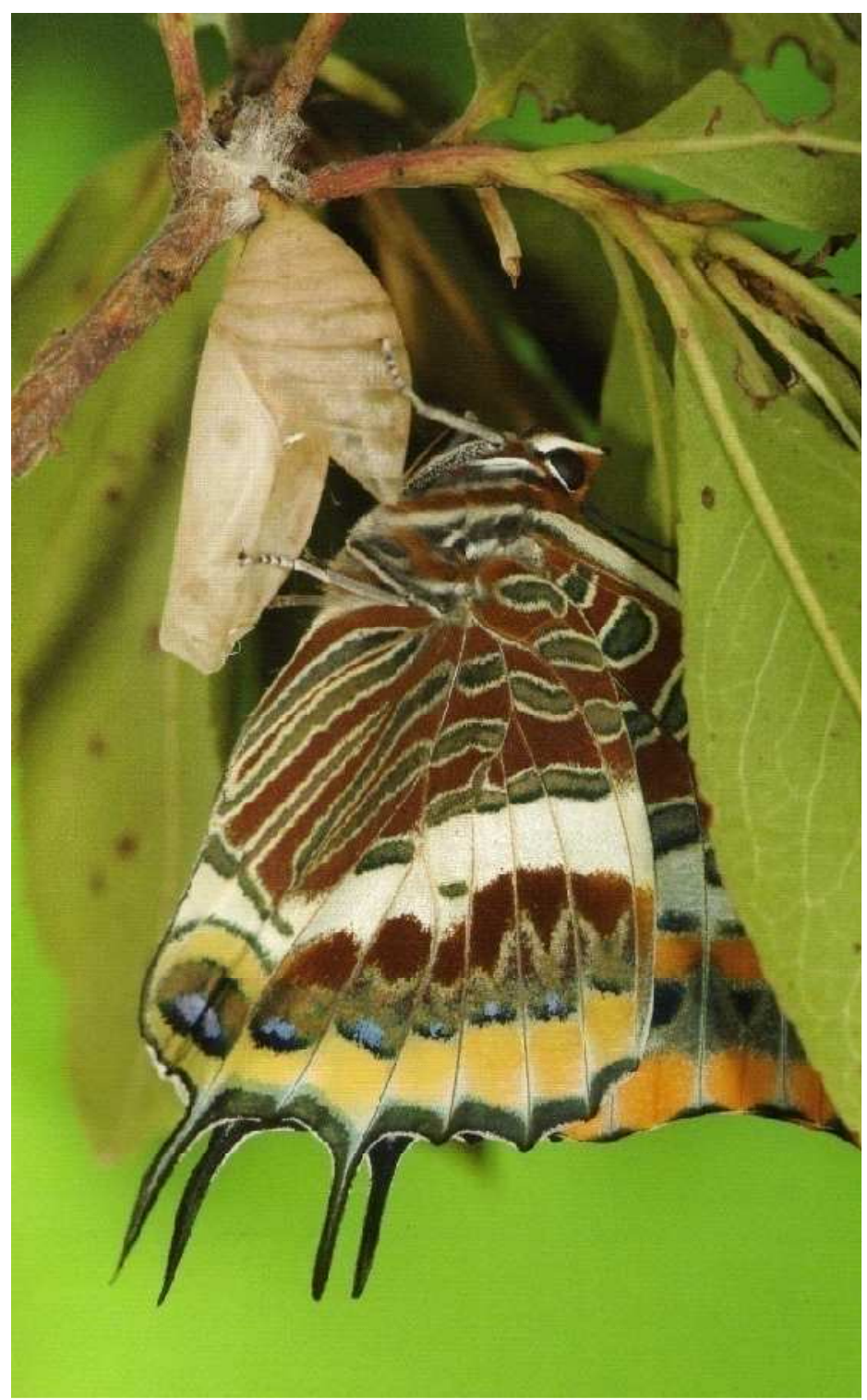

Ilustración 53. Imago recién emergido de Charaxes Jasius. 

5.2. El proceso de fundición artística a la cera perdida. 
El segundo proceso que analizaremos será el proceso de fundición a la cera perdida. Este, al igual que ocurría con el ciclo vital de la mariposa no creemos que deje indiferente a nadie que pueda contemplarlo. El olor, el calor, el color incandescente del metal fundido hace que nos estremezcamos ante este proceso artístico.

Los principales elementos que forman este proceso son; el fuego, la cera y el metal. En este caso, al hablar de metal estamos refiriéndonos al bronce. $Y$ ¿Qué es el bronce? Este metal es una aleación formada por estaño y cobre. El estaño hace que baje el punto de fusión del cobre, permite que sea capaz de reproducir con mayor fidelidad los relieves y formas del molde y le otorga dureza. El resultado es una aleación capaz de soportar el paso del tiempo sin sufrir deterioros. Considerado un material noble, el bronce, ha sido utilizado en escultura ininterrumpidamente a lo largo de la historia. También posee una sonoridad y una brillantez digna de mención.

Desde que el hombre primitivo fue capaz de controlar y trabajar los metales ha seguido innovando e investigando ininterrumpidamente nuevos materiales para moldes y técnicas de creación. El bronce comenzó a utilizarse sobre el año 3000 a.C. en el comienzo de la que más tarde se denominaría Edad de Bronce.

Desde su aparición el Hombre no ha dejado de utilizar este material tanto para crear esculturas, herramientas, piezas necesarias para otros procesos... y ha seguido innovando en su proceso de trabajo, pues el bronce no puede ser utilizado directamente, sino que debemos fundirlo aplicándole calor, para que sea capaz de reproducir una forma ya existente.

Desde la Antigüedad hasta nuestros días, el proceso de fundición en bronce ha ido variando. Al principio el molde utilizado era el barro, la arcilla, las piedras...después este molde evolucionó y el material utilizado para realizarlo era la escayola y el ladrillo molido, el cual formaba una especie de pasta para crear el molde de olla o chamota. En la década de los cuarenta del pasado siglo XX se desarrolla en EE.UU. el proceso de fundición a la cera perdida con molde de cáscara cerámica. 
Este último es el proceso que más nos interesa, el cual también ha evolucionado desde sus inicios hasta nuestros días gracias sobre todo a las nuevas tecnologías y a la química. Su uso, también ha variado con el paso del tiempo. Algunos artistas contemporáneos ven en la utilización del bronce un retroceso al pasado y otros lo utilizan como parte de instalaciones o intervenciones, lo trabajan principalmente por su plasticidad y capacidad reproductiva.

El proceso de fundición artística a la cera perdida con molde de cáscara cerámica consta de siete fases bien diferenciadas:

1. Mezcla de materias primas para la creación de una cera con las propiedades adecuadas para el trabajo a realizar (resina de colofonia, cera virgen y parafina).

2. Elaboración del modelo en cera y del sistema de colada.

3. Elaboración del molde cerámico (Sílice coloidal y moloquita).

4. Descere: eliminación del modelo interno de cera. Cocción del molde cerámico.

5. Colada en bronce.

6. Desmoldeo y extracción de la pieza en bronce.

7. Limpieza y pátina de la pieza en bronce. 


\section{La cera para fundición.}

Al igual que ocurría en el ciclo vital de la mariposa, la primera fase es una de las más importantes porque dependiendo de la calidad y porcentaje de las materias primas utilizadas en la creación de la cera, está, poseerá unas propiedades $u$ otras.

- “(..) ¿qué es una cera? responder que es una materia plástica, de bajo punto de fusión, combustible, que no se seca y mantiene su forma (en condiciones no extremas de temperatura), con alta capacidad de reproducción de formas y texturas en estado viscoso o semilíquido, semitras/úcida, es decir, que deja pasar levemente la luz a su través (lo que hace merecedora de ese gran parecido con la carne humana que exhiben los museos), impermeabilizante, o sea que repele el agua y por tanto, hidratante indirectamente, y medianamente adherente". ${ }^{144}$

La cera ha tenido múltiples usos desde la Antigüedad, sus utilizaciones más comunes han sido: en velas y cirios, escritura con estilete, el lacrado de documentos, reproducciones, como impermeabilizante, en pulimentos, en recetas medicinales... No todas las ceras son iguales y dependiendo de su composición y proporción poseen unas características u otras. Varían en su color, olor, impermeabilidad, plasticidad, pudiendo clasificarlas en naturales o sintéticas. Ejemplo de naturales sería la cera virgen proveniente de las abejas y como ejemplo de las sintéticas sería la parafina, que proviene del petróleo.

La cera se utiliza en el proceso de fundición por su gran plasticidad, porque funde a baja temperatura y enfría relativamente rápido, es maleable, tiene una gran capacidad de reproducción, no tiene un alto coste, es de fácil disponibilidad, hay un sinfín de modos de utilizarla (tallada, soldada, recortada...), mezcla bien con otras sustancias, y además es hidrófoba, lo que nos va a ser muy útil a lo largo de todo el proceso.

Pero no podremos obtener unas condiciones óptimas para la realización de la pieza en bronce, si sólo utilizamos un tipo de cera. La cera virgen podríamos calificarla como blanda y la parafina por el contrario, sería una cera dura. Su mezcla en la proporción adecuada más el aporte de la resina de colofonia crea una cera más moldeable, menos deformable, más adhesiva y

\footnotetext{
${ }^{144}$ MARCOS MARTínEZ, Carmen. "Tesis Doctoral. Fundición a la cera perdida: Técnica de la cascarilla cerámica". Ed. Universidad Politécnica de Valencia. Valencia, 2001. Pág. 26.
} 
con mayor plasticidad, que posee las condiciones necesarias para la realización y reproducción de la obra imaginada por el artista.

Las proporciones de estos tres elementos pueden variar según la temperatura ambiente, pero se suele trabajar con un 60 ó $70 \%$ de cera virgen, un 20 ó $10 \%$ de parafina y un 30 ó $10 \%$ de resina de colofonia.

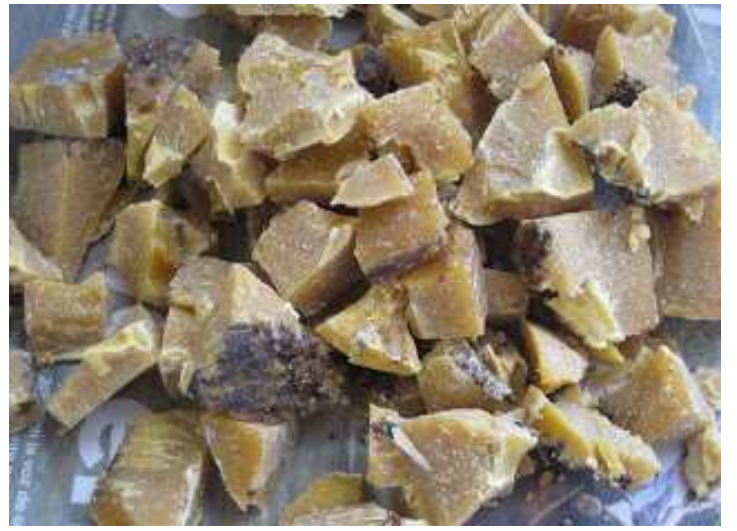

Ilustración 54. Cera virgen

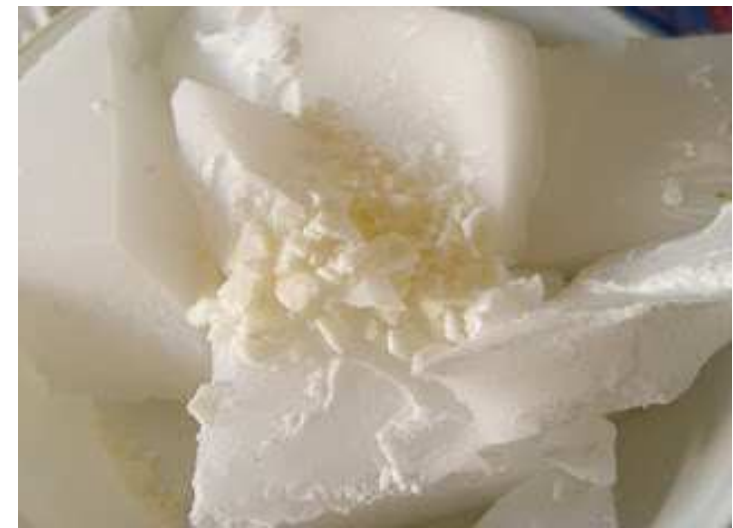

llustración 55. Parafina.

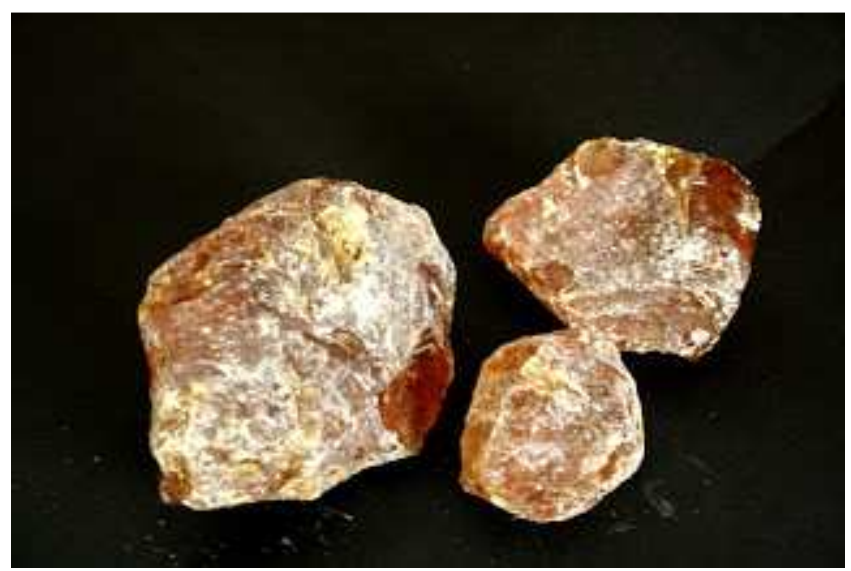

Ilustración 56. Resina de colofonia. 


\section{Elaboración del modelo en cera y del sistema de colada.}

Una vez obtenida la mezcla óptima de ceras, el siguiente paso es realizar el modelo en este material y colocarle los bebederos que son como ríos que se encargan de transportar el metal fundido hasta cualquier lugar de la pieza evitando rechupes o faltas.

Una vez obtenida la "cera ideal", habrá que verterla o manipularla para obtener un modelo de tamaño real que represente a la obra. Como podemos leer en la Tesis Doctoral de Carmen Marcos: "El modelo es el requisito previo a todo proceso de fundición (...) Esto implica que el trabajo tenga el tamaño real que se desea obtener, así como la forma y textura deseados, puesto que en el campo de la fundición se considera modelo al objeto sobre el cual se elabora directamente el molde de fundición, transmitiéndose las formas del primero al segundo, y de éste al metal fundido". ${ }^{145}$

La cera puede ser trabajada de múltiples formas; tallada, recortada, soldada, doblada, vaciada, modelada... Por todas las cualidades nombradas anteriormente, la cera es el material escogido por el artista para crear una mímesis de la pieza definitiva. Una de sus propiedades más apreciadas es que puede reproducir fielmente cualquier textura, marca o impresión que el escultor quiera que posea la obra final en bronce.

Es un material relativamente fácil de trabajar, su bajo punto de fusión ayuda a la hora de realizar soldaduras e incluso se puede llegar a manipular y darle forma con el calor que desprenden nuestras propias manos. Al repeler el agua, es más fácil extraerla de los moldes porque éstos se humedecen o se sumergen en ella, antes de aplicarles o verterles la cera.

El material escogido para la realización de estos moldes suele ser la escayola por su porosidad y poder de absorción del agua, su disponibilidad y su bajo precio. Esto ayuda a que una vez húmedos, la cera que está en contacto con ellos se enfríe y no se adhiera al molde, liberándose con facilidad.

\footnotetext{
${ }^{145}$ MARCOS MARTÍNEZ, Carmen. "Tesis Doctoral. Fundición a la cera perdida: Técnica de la cascarilla cerámica”. Op. Cit. Pág. 51.
} 
Estos moldes se suelen utilizar para la realización de bebederos, troncos y copas necesarios en la estructura del árbol de colada. Para ello, en algunos casos la cera es vertida en el molde de escayola llenándolo por completo de una manera pausada y constante, otras veces se añade una cantidad de cera al molde y se voltea para que al enfriarse se quede adherida a las paredes hasta obtener el grosor deseado, en otros casos se puede aplicar la cera con pincel e incluso se puede llenar en su totalidad el molde y cuando veamos que se ha formado una capa del grosor deseado volcarlo para eliminar la cera sobrante. También se utilizan moldes de escayola, humedecidos previamente, normalmente con forma rectangular o cuadrada para crear planchas de cera con el fin de realizar las piezas, y podemos obtener resultados similares si acotamos un espacio con maderas, lo humedecemos y vertemos la cera.

Una vez realizado el modelo en cera, el siguiente paso es crear un árbol de colada mediante el cual nos aseguremos que todas las partes del molde cerámico hueco quedarán regadas por el bronce fundido evitando defectos en la pieza final. El molde en cera más el árbol de colada se deberán de colocar en posición invertida para poder verter en ellos, el metal fundido.

El árbol de colada está formado por una serie de bebederos, de diferentes grosores y tamaños, una copa o vaso de colada por donde se verterá y alojará el metal fundido y unos respiraderos para facilitar la extracción de los gases y el aire que se acumulen en la pieza a causa del metal. La copa o vaso de colada, llamado también bebedero principal, normalmente posee unas paredes de un grosor de 3 a $5 \mathrm{~mm}$. Está unida al bebedero principal y su misión es alojar y soportar el vertido del metal fundido, por lo que debe de tener una forma similar a un embudo.

Los bebederos tienen forma cilíndrica y su tamaño y grosor dependerá de las dimensiones de la pieza a realizar en bronce, pero no suelen ser largos ni muy gruesos. Su número también irá en función de la complejidad de la pieza a reproducir. Deben de colocarse con cierta inclinación y deben de tener una superficie lisa para mejorar el paso del metal.

Los bebederos pueden dividirse en primarios o secundarios, dependiendo de la importancia de la zona de la pieza que tengan que regar. Existe un 
bebedero primario unido al principal o copa y a la pieza con el sistema de colada ya montado, que posee un grosor considerable y es más bien corto, que su misión es sostener a la pieza con el árbol de colada, recibir el metal fundido y distribuirlo por el resto de bebederos. Estos bebederos, llamados secundarios tienen la función de distribuir el metal fundido por todas las partes de la pieza por igual, evitando cualquier problema en la pieza final.

Para ello, los colocamos en posición ascendente y en ángulo agudo para ayudarse de la fuerza de la gravedad.

Si utilizamos la técnica de la chamota en vez de la de cáscara cerámica, el número de bebederos y respiraderos aumentará, la copa será más alta y estrecha, y necesitará un desagüe para ayudar en algunos casos a expulsar la cera de la pieza. 


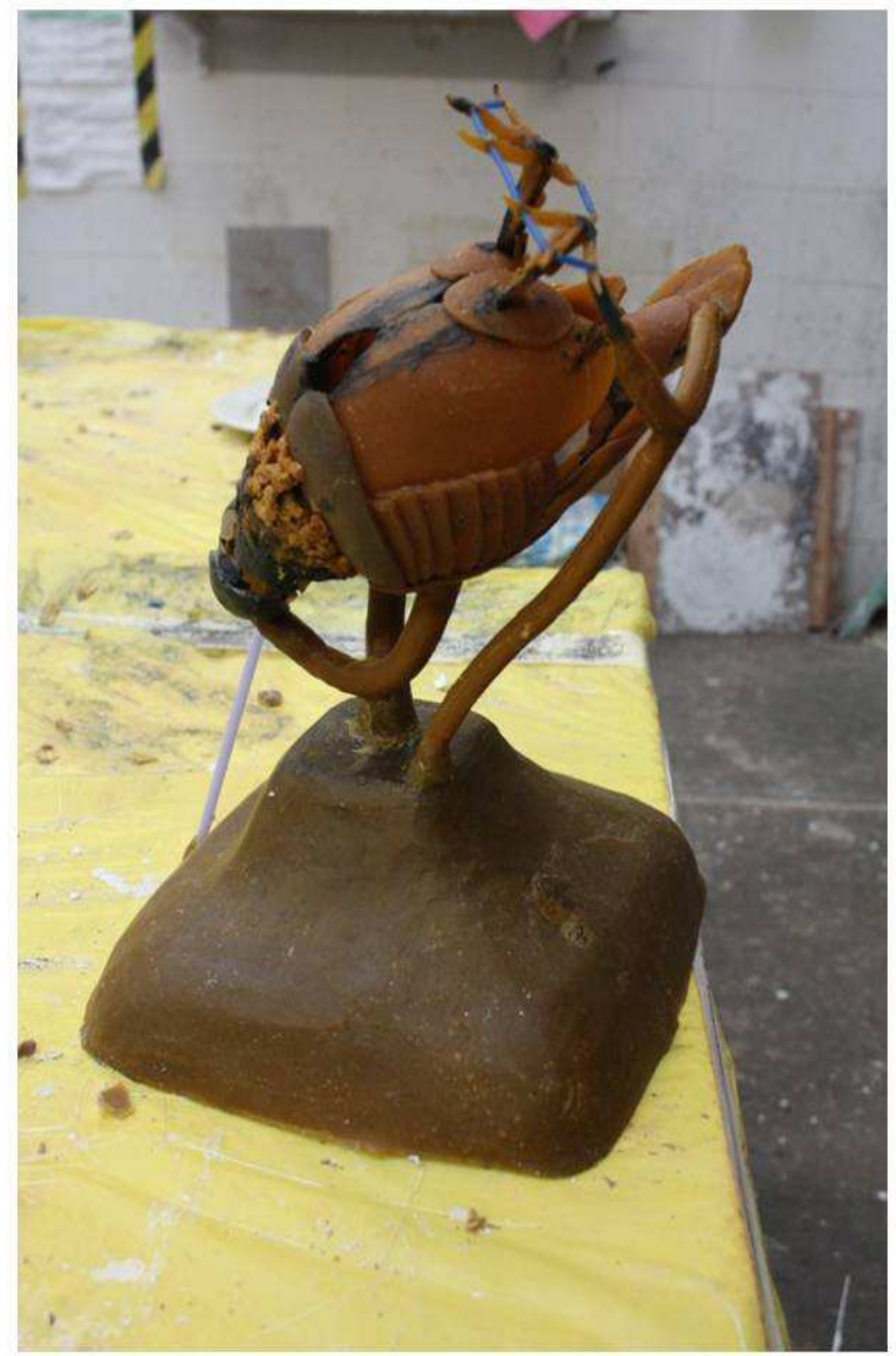

Ilustración 57. Modelo en cera con su correspondiente árbol de colada. Pieza de Gil Gijón. Perdiz roja. Curso 2012-13. Facultad de Bellas Artes de la U.P.V. 


\section{Elaboración del molde cerámico.}

Después de la creación del árbol o sistema de colada, el siguiente paso es crear un molde cerámico que lo cubra por completo y sea capaz de aguantar la elevada temperatura del metal fundido. También debe de ser poroso para poder eliminar en la medida de lo posible los gases que acompañan al metal fundido durante la colada.

La cáscara cerámica es el material elegido para la realización de este molde. Es una mezcla de material cerámico de diferente grano denominado, moloquita (capaz de aguantar altas temperaturas) y un aglutinante, sílice coloidal (mantiene unidas las partículas de la moloquita y tiene mayor poder refractario que el resto de aglutinantes). De la mezcla de la moloquita en polvo y el sílice coloidal líquido, obtendremos una pasta densa a la que denominaremos papilla o barbotina cerámica. El modelo en cera, con su árbol de colada completo, es bañado con la papilla o barbotina cerámica y sobre ella se aplica un granulado fino del mismo material cerámico, la moloquita. Tras aplicar varias capas obtendremos un molde cerámico capaz de aguantar altas temperaturas, resistente, poroso, con un buen registro, capaz de separarse del metal una vez solidificado, ligero, con facilidad para ver los posibles defectos. Este molde debe ser descerado y cocido, y aplicándole calor previamente, evitaremos un choque térmico al entrar en contacto con el metal fundido.

- "Llamamos cascarilla cerámica a una técnica de fundición en la cual el molde- que es desechable, o perdido- se elabora por capas sucesivas de una barbotina 0 papilla cerámica y un estuco o un granulado cerámico aplicadas sobre un modelo, también perdido, habitualmente creado en cera". ${ }^{146}$

Esta fase es una de las más importantes del proceso de fundición y por tanto, según sea el tipo de molde utilizado en el proceso, éste recibirá un nombre determinado. Si el molde es de arena, esa técnica se llamará fundición a la arena, si el molde es de cáscara cerámica, fundición a la cera perdida con molde de cáscara cerámica y si el material refractario es la chamota, recibe el nombre de fundición a la cera perdida con molde de chamota.

\footnotetext{
${ }^{146}$ MARCOS MARTíNEZ, Carmen. "Tesis Doctoral. Fundición a la cera perdida: Técnica de la cascarilla cerámica". Op. Cit. Pág. 203.
} 
Para crear el molde cerámico, lo primero, es asegurarse de que el árbol de colada está colocado correctamente y la pieza es capaz de mantenerse por sí misma. El siguiente paso, es aplicarle a la pieza una capa de goma-laca disuelta en alcohol, para poder aplicarle la papilla o barbotina a la pieza y que ésta no la repela, debido al agua que contiene el sílice coloidal líquido. Se le añadirá pigmento de carbón vegetal para poder ver a simple vista dónde hemos aplicado la goma laca y asegurarnos de que todo el árbol de colada queda impregnado de esta capa adherente.

A continuación se le aplicará una primera capa de papilla o barbotina hecha con la moloquita en polvo (granulometría de -200), asegurándonos que la cubra por completo y su densidad sea viscosa. De ella, dependerá la capacidad de reproducción del modelo. El periodo de secado de esta primera capa conviene que sea más largo que el resto de capas.

Después del secado correspondiente, pasaremos a aplicar varias capas de papilla o barbotina y estuco de grano fino (30-80) y posteriormente a su secado, aplicarle varias capas de papilla o barbotina y estuco de grano medio (16-30), que otorgarán a la pieza una mayor resistencia. Hay que dejar un periodo de secado de cuatro horas como mínimo entre los baños cerámicos de las capas intermedias, si bien esto es relativo y varía según el tamaño y tipo de pieza de que se trate, pero tanto la primera como la última capa necesitarán un mayor tiempo de secado. La zona de secado debe de estar a una temperatura estable, ventilada y sin humedad, para evitar posibles cambios o leves movimientos en la cera que pudieran afectar al molde. 


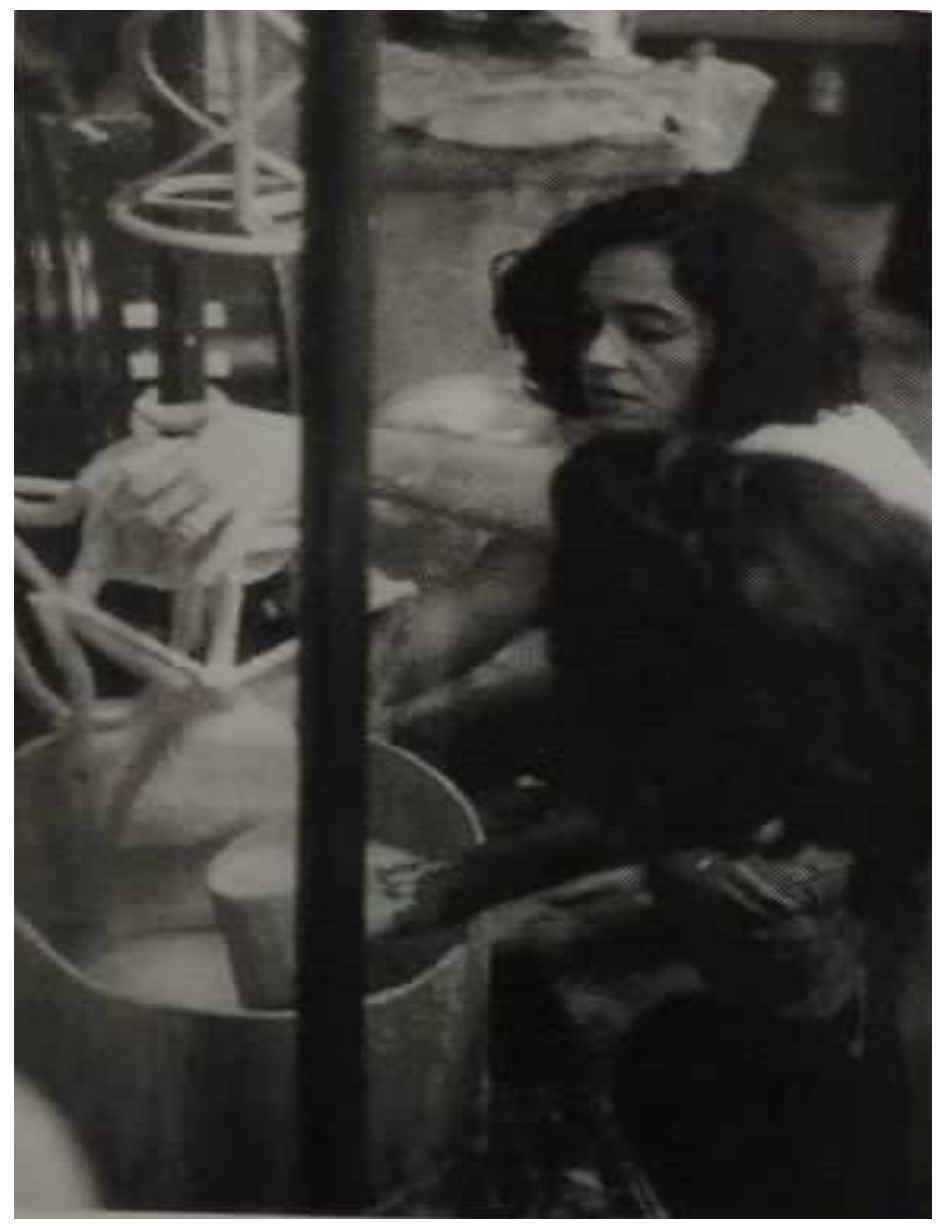

Ilustración 58. Aplicación de una de las capas del revestimiento de cáscara cerámica. Profesora Carmen Marcos Martínez. 


\section{Descere y cocción del molde de cáscara cerámica.}

Una vez creado el molde de cascarilla cerámica, continuaremos con la siguiente fase que es, el descere y cocción del molde cerámico.

- "Con el término descere nos referimos a la parte de la técnica de la cascarilla cerámica en la que el molde es sometido a la acción del calor para secarlo y para derretir la cera del modelo. El término cocción se refiere a la parte del proceso que, íntimamente ligada al descere en tiempos y espacios, pues se produce en el mismo lugar y a continuación del anterior, tiene como objetivo el endurecimiento del material del molde por su sinterización, eliminando además todo resto orgánico y de humedad. La cocción es, al final y al cabo, la que produce realmente el molde cerámico". ${ }^{147}$

Este descere se viene realizando desde décadas pasadas en un horno que se denomina, campana de descere. Este horno se puede realizar mediante un bidón recubierto por manta cerámica y unas poleas que le ayuden a bajar o a subir según lo requiera el tamaño de la pieza o el momento del descere. La pieza debe de ir colocada sobre una rejilla firme capaz de soportar su peso y su finalidad es que la cera una vez derretida por el aporte de una fuente de calor como suele ser un soplete enganchado a la rejilla, pueda caer a un contenedor con agua que se encuentra en la parte inferior.

Todo ello, va colocado en una estructura de metal estable y firme que evitará cualquier peligro y dará estabilidad al descere. La campana de descere no tiene unas medidas fijas, ya que dependerá del tamaño de las piezas que vayamos a descerar.

\footnotetext{
${ }^{147}$ MARCOS MARTínEZ, Carmen. Tesis doctoral "Fundición a la cera perdida: Técnica de la cascarilla cerámica". Op. Cit. Pág. 372.
} 


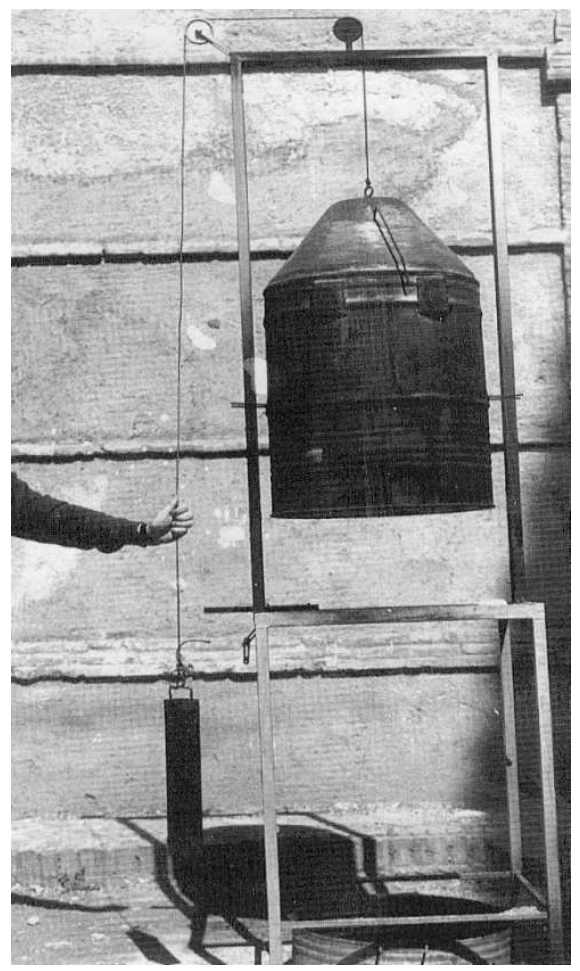

Ilustración 59. Horno con polea para ser elevado. Su uso está recomendado para sacar las ceras a los moldes de cáscara cerámica.

En el proceso tradicional instaurado por Mr. David Reid, el descere y la cocción del molde se da en el mismo momento al aplicarles la fuente de calor. El primer paso es calentar el horno (campana de descere) para producir un choque térmico al introducir la pieza. Una vez caliente, la pieza se colocará en el centro de la rejilla y se bajará el bidón recubierto de manta cerámica hasta una medida óptima y se le aplicará calor. Esto hará que la pieza quede libre de cera y además que el material del molde pase a convertirse en material cerámico con una mayor porosidad, dureza, resistencia a altas temperaturas... Una vez terminado el descere y cocción, la pieza es sacada de la campana y colocada en un lecho refractario. El color anaranjado que ha adquirido durante el proceso, nos permite apreciar si contiene grietas. Si la pieza no presenta ningún problema o presenta alguna grieta casi imperceptible, sólo quedará una vez enfriada, darle una capa de seguridad con papilla o barbotina y el último tamaño de estuco que se le había aplicado a la pieza antes del descere y dejarla secar el tiempo correspondiente. En el caso de grietas finas esta capa 
de refuerzo o seguridad debe de estar muy bien aplicada, para sellarlas. Se puede dar una última capa sólo con papilla o barbotina para evitar que los granos de estuco se desprendan y caigan en el interior de las piezas contiguas en el momento de colocación en la colada en bronce. Si por el contrario la pieza presenta alguna grieta gruesa, o por algún golpe le falta cascarilla en alguna zona o bien nos parece que hay zonas más debilitadas que otras, se debe de añadir papilla o barbotina, fibra de vidrio para reparar la falta o grieta, encima de ésta, más papilla o barbotina y estuco del mismo grano que la última capa antes del descere y dejarla secar al menos cuatro horas o calentar la zona con un soplete. Hay que añadirle fibra sólo en las zonas que corresponda, pues el molde pierde su porosidad en la zona donde ésta se encuentre. Si se cree conveniente se le puede añadir un último baño sólo con papilla o barbotina para que el grano no perjudique a la pieza en la colada.

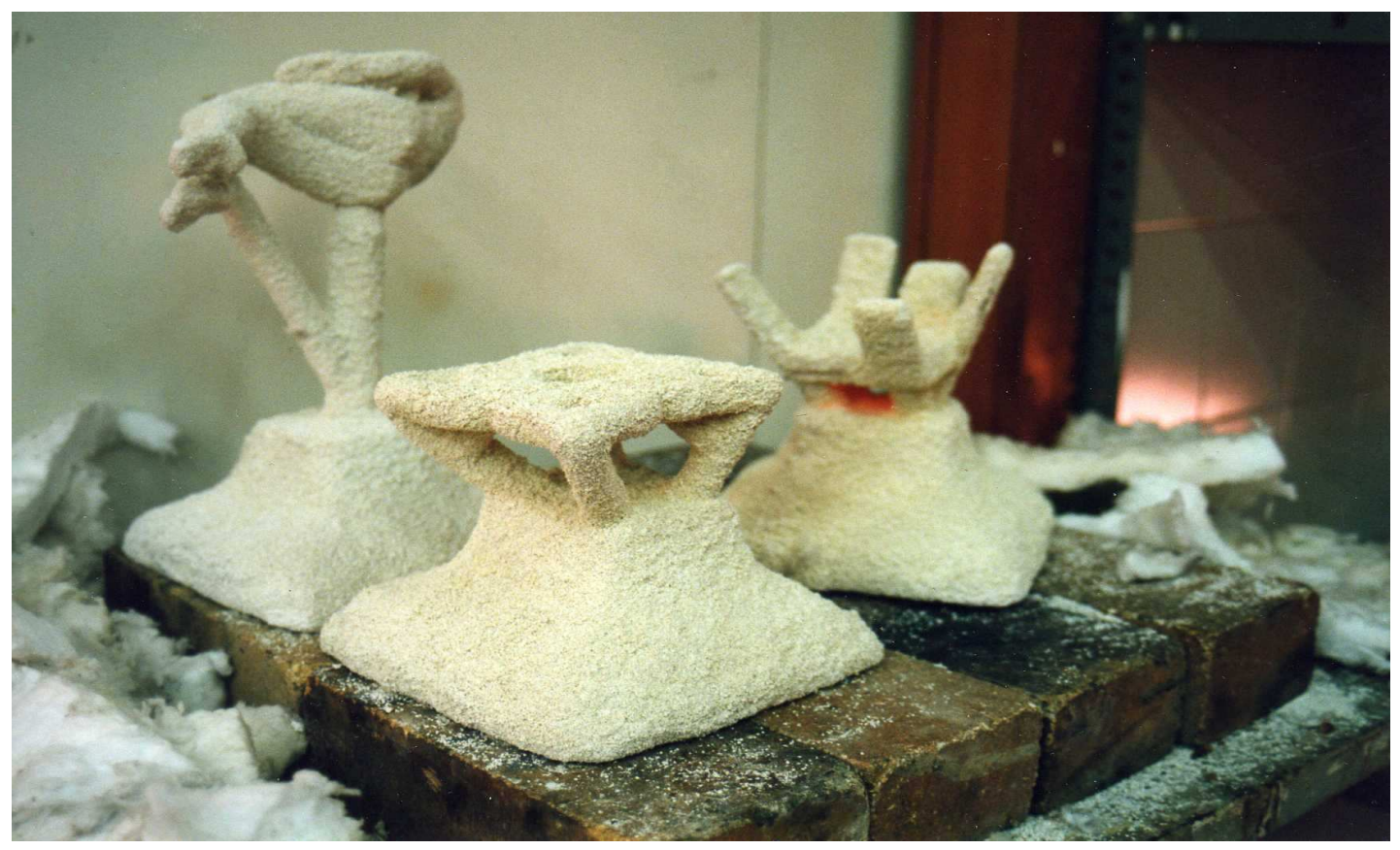

Ilustración 60. Estado de la pieza después del descere y la cocción. 


\section{Colada de bronce.}

El siguiente paso en el proceso de fundición, es la colada en bronce. Para ello, se deben de colocar las piezas en un lecho de colada, en posición invertida con lo que la copa queda en posición de recipiente para recibir el metal fundido. Las piezas se colocan en el citado lecho de colada, una especie de horno recubierto de material refractario donde estarán suspendidas apoyadas en varias pletinas o barras de acero asegurándonos que la copa se encuentre bien sujeta. Una vez colocadas se cierra el horno o lecho con su tapa y se procede a calentarlas mediante un soplete, evitando así un choque térmico al verter en el molde el metal fundido.

Si el molde fuera de chamota, este choque térmico sí que tendría lugar, ya que el molde no se calentaría previamente porque estaría enterrado en el momento de la colada.

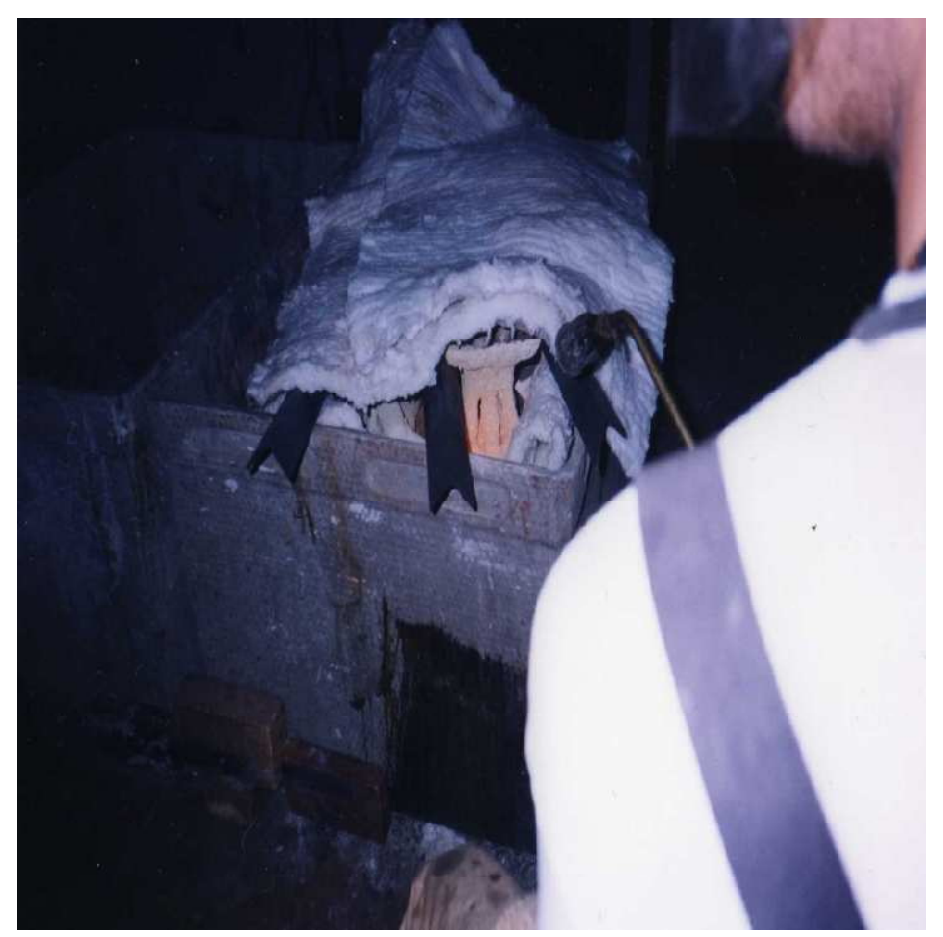

llustración 61. Precalentamiento de las piezas antes de la colada en bronce. 
El bronce se coloca en el interior de un crisol y éste a su vez en el interior de un horno preparado para generar y resistir altas temperaturas. Una vez se está fundiendo el metal se le añade un poco de fósforo para aumentar su fluidez.

El metal fundido hay que verterlo de una manera constante, para evitar problemas con el aire que pudiera entrar en la pieza y además, porque debe de llenar primero las diferentes partes de la pieza y por último los respiraderos y la copa, la cual nos va a servir de almacenamiento del bronce por si la pieza necesitara mayor cantidad del previsto.

La idea es que el metal que entra en el molde registre la superficie de éste rápidamente, evitando cualquier defecto en la pieza final.

Una vez el metal se encuentra alojado en el molde cerámico, debe de enfriarse y solidificarse. Para ello, o bien se deja reposar y enfriar el bronce por si solo de una manera lenta y estable o después de un periodo de reposo y enfriamiento se le añade agua de modo selectivo al molde. 


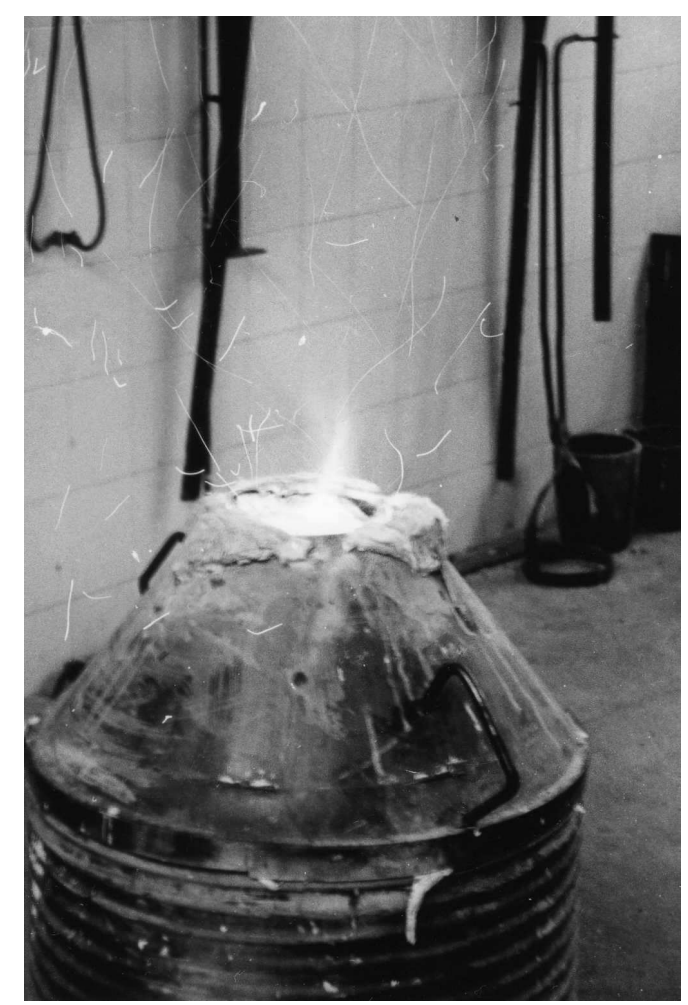

Ilustración 62. Horno de fundición.

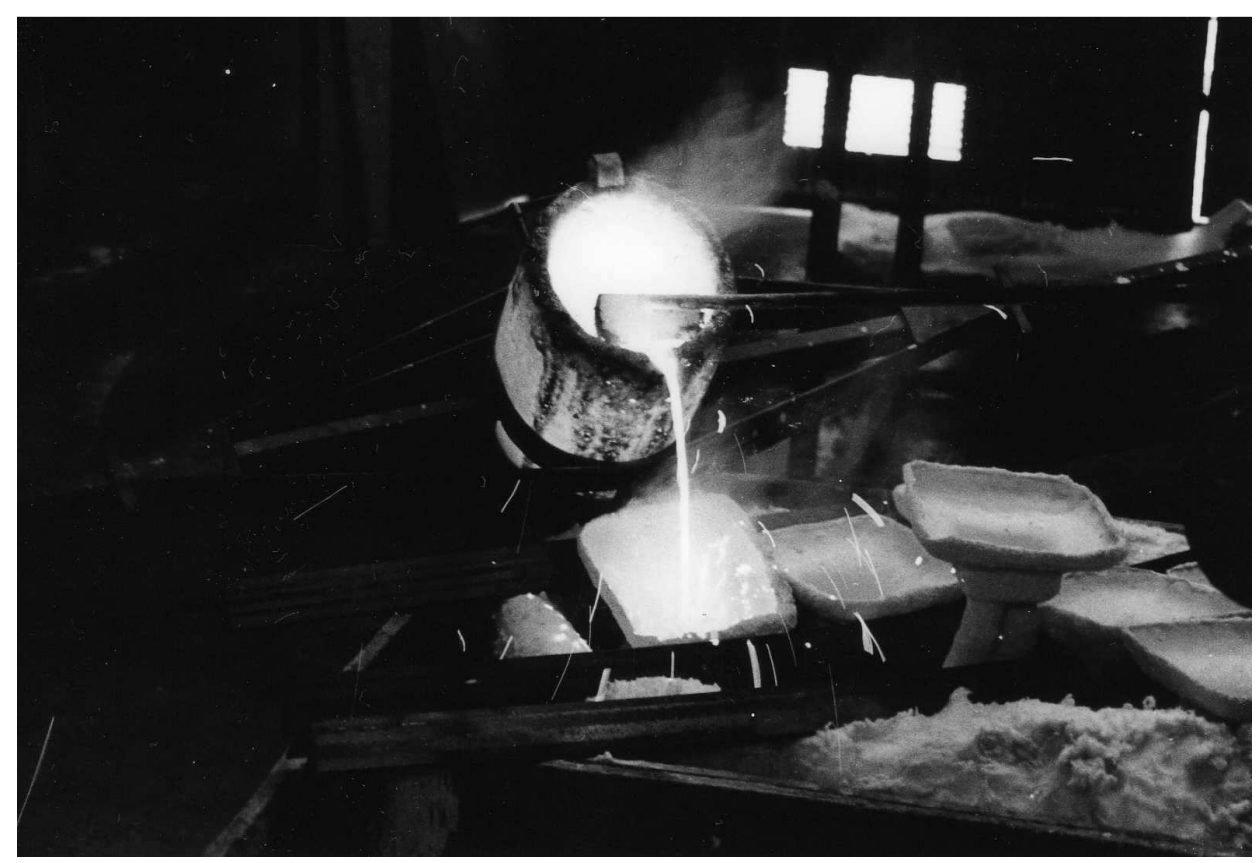

Ilustración 63. Colada en bronce. Momento del vertido del metal fundido en los moldes de cáscara cerámica. 


\section{Desmoldeo y extracción de la pieza en bronce.}

Una vez el metal se ha enfriado y solidificado, pasamos al siguiente paso del proceso de fundición, el desmoldeo y extracción de la pieza en bronce. Para ello, el molde cerámico debe de ser eliminado y este proceso se lleva a cabo de una manera manual con un cincel y un martillo, posteriormente se le pasará un cepillo metálico. Si la complejidad de la pieza impidiera eliminar los restos del molde, tendríamos que utilizar técnicas más agresivas como pueden ser los ácidos, la sosa o el chorro de arena.

Una vez eliminado por completo el molde cerámico, el siguiente paso será deshacernos del árbol de colada para liberar la pieza en bronce. Para ello, utilizaremos medios mecánicos como radiales o sierras. Para los restos ya cortados de bebederos utilizaremos limas, cepillos y fresas.

Una vez libre la pieza en bronce, podremos observar si es una reproducción exacta del modelo creado en cera, y si es así, sabremos que el proceso de fundición artística ha sido resuelto con éxito. Sólo nos restaría aplicarle una pátina de color o pulirla. 


\section{Limpieza y pátina de la pieza en bronce.}

Por último, nos quedaría la limpieza y patina de la pieza en bronce.

Tras limpiar la pieza de polvo y restos cerámicos, la pieza está preparada para recibir el brillo y color que le otorguen el aspecto visual que se merece un material noble como el bronce. Para ello, habrá que calentarla o aplicarle alguna pátina, después, se someterá a un proceso de abrillantado y encerado.

El requisito previo para comenzar el proceso de patinado es la limpieza profunda y desengrasado del metal, con buenos cepillos, agua y jabón. La mayoría de colores se obtienen por la aplicación de la mezcla de diversos productos químicos con pincel en la pieza calentada a soplete, atacando así su superficie. Otro modo más natural es aquel por el que se obtiene la gama de rojos, pues se debe de calentar la pieza hasta el rojo vivo y a continuación echarle agua fría o sumergirla rápidamente en arena de sílice (aleación 85-5). Todas las pátinas dependen en su duración de varios factores, entre los que destacan las dimensiones y grosor de la pieza.

Una vez obtenida la pátina deseada sólo nos queda someter a la pieza a un proceso de abrillantado y encerado para embellecer, aún más si cabe, el metal. 


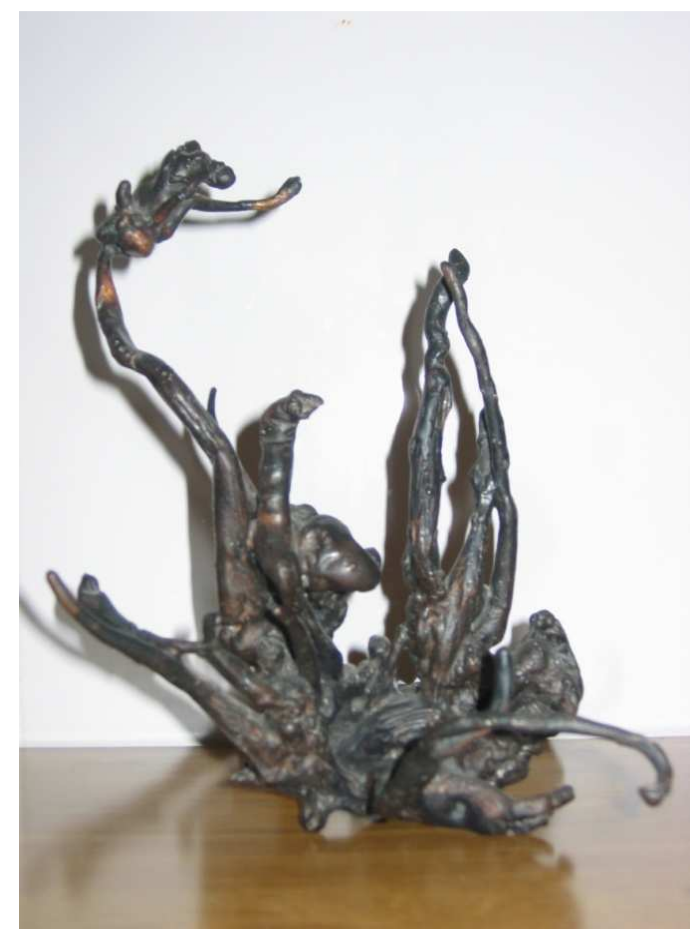

Ilustración 64. Vegetal. Año 2000. Laura Pinilla Zapater. 

5.3. Comparación poética entre el ciclo vital de la mariposa y el proceso de fundición artística a la cera perdida. 
Una vez descrito el ciclo vital de la mariposa y el proceso de fundición artística, podemos crear una conexión poética e imaginativa entre ambas, basándonos en el estudio ya realizado del ser humano como una especie más de la naturaleza y la obra de arte como prolongación del artista. En capítulos anteriores también hemos tratado de dotar de vida la obra de arte al ser poseedora y proyectar los sentimientos, sensaciones, ideas y vivencias del artista, transmitiéndole este su energía y naturaleza. Este hecho también dota de naturaleza a los procesos artísticos por medio de los cuales se crea la obra de arte, convirtiéndose en una especie de vía entre el hombre-artista y su obra. Gracias a esta naturaleza otorgada en nuestro caso concreto al proceso de fundición artística a la cera perdida, podemos crear esta comparativa entre ambos procesos. Para poder desarrollar esta idea, nos centraremos en dotar de vida a los diferentes elementos que conforman el proceso de fundición, como son el fuego, la cera y el metal.

Las conexiones entre ambos procesos irán más allá de las meras coincidencias apreciables a simple vista como el hecho de que ambos procesos son complejos y que poseen una belleza atrayente.

Basta con observar de una manera más poética ambos procesos, para darse cuenta de que, la calidad de los nutrientes iniciales marcará en gran medida el porvenir del resultado final, que el elemento fuego está presente en ambos procesos mediante la temperatura o la digestión de la oruga. Existe un crecimiento y un desarrollo tanto por parte del lepidóptero como por parte de la obra de arte. También se crea un espacio mágico, protector y místico en ambos procesos en el momento en que la oruga crea y se oculta en el interior de la crisálida. Allí realiza la metamorfosis, proceso mediante el cual se convierte en un nuevo ser. Estas cualidades también se le pueden aplicar al hueco que obtenemos al descerar y cocer el molde cerámico, por estar cargado de significado, pues todo lo que se nos oculta y no podemos percibir, aviva nuestra imaginación.

También podemos crear una conexión mediante el resultado final de ambos procesos, debido a que en ambos, el producto inicial desaparece para dejar paso a otro totalmente nuevo, el cual puede sufrir una serie de 
deformaciones tanto internas como externas si no se toman las medidas adecuadas a lo largo de todo el proceso. Una vez enfriado el bronce y secadas las alas de la mariposa, será el momento de que el color haga su aparición llenándolo todo de diferentes tonos y matices. Esta diversidad de tonos se obtendrá al verse afectada la oruga en su proceso de metamorfosis, por factores externos como la temperatura y la humedad. El bronce también obtiene algunas de sus tonalidades en procesos que requieren un aumento de la temperatura y posteriormente, una bajada drástica de esta.

Para comenzar con el análisis de las coincidencias nombradas anteriormente, debemos ampliar el estudio ya realizado anteriormente del ser humano y su lugar en el mundo natural.

Para ello, debemos retroceder hasta los orígenes del mundo y observar como todos los seres vivos han sufrido una evolución continua desde su aparición hasta nuestros días y que sólo los individuos más fuertes o con peculiaridades han sido capaces de adaptarse al medio en el que se encontraban.

El hombre al igual que la mariposa lleva en este mundo millones de años. Según podemos leer en la obra de Roberto de la Maza (1987) "Mariposas Mexicanas", se tiene poca información debido a la fragilidad de sus cuerpos, pero se sabe que a mediados del Eoceno, hace aproximadamente 48 millones de años, aparecen en el continente americano los primeros insectos con las características de un lepidóptero, cuyos fósiles se encontraron en Colorado, Estados Unidos. ${ }^{148}$

En el caso de la evolución del ser humano "para los paleontólogos, el punto de inicio de la historia de la humanidad empezó con la aparición de los primates hace unos 65 millones de años (...). Entre las especies que pertenecen a los primates están, además del ser humano, los simios, monos y musarañas (...) Después de la separación entre el ser humano y el chimpancé, apareció el primer homínido, el llamado Australopithecus, que posteriormente

\footnotetext{
${ }^{148}$ http://www.bibliotecasvirtuales.com7biblioteca/Articulos/AbrahamBastidaAguilar/ mariposamonarca.asp $\quad(13 / 1 / 2.010$ a las $16: 10 \mathrm{~h})$.
} 
dio lugar al Homo Habilis, el primer espécimen del género Homo, al que pertenecemos los seres humanos modernos." ${ }^{149}$

Al hablar de seres vivos, además del hombre, también estamos haciendo referencia a los animales (incluyendo a los lepidópteros), las plantas y los microorganismos. De todos ellos, el ser humano es quien ha sufrido una evolución más importante, debido a su capacidad de raciocinio.

Este hecho, como venimos comentando a lo largo de toda la tesis, en vez de acercar al ser humano al resto de seres vivos y tratarlos en hermandad y protegerlos, ha creado una brecha, un distanciamiento al creerse superior al resto de seres del planeta, y también de la "Madre" naturaleza. Nos hemos alejado de ella pensando que eso nos convierte en superiores, pero en realidad sólo estamos negando nuestros instintos naturales lo cual nos lleva en la mayoría de casos a una infelicidad constante. Somos esclavos laborales en trabajos que no nos definen sólo porque nos han impuesto la constante necesidad de consumir objetos que ni necesitamos ni nos hacen felices.

Joseph Beuys en una entrevista con Elizbeth Rona, en octubre de 1981 ante la pregunta de si existía una crisis general, él respondió que nos encontrábamos a las claras, en una crisis tan profunda que no podíamos saber si los hombres vivirían todavía en este planeta a finales de siglo. Si continuaba la destrucción del entorno, así como el sistema económico tal como lo concebía el capitalismo, con la explotación de la tierra, el aniquilamiento de la forma de vida natural, la amenaza que pesaba sobre la salud del hombre, podíamos decir que la vida humana estaría realmente amenazada antes de que terminara el siglo. La humanidad se encontraba así sumergida en una profunda crisis a la que conducían los intereses del poder, del capital, del dinero, del Estado. Tales eran los principales enemigos de la humanidad. ${ }^{150}$

Pero el hombre todavía posee ciertas necesidades básicas que lo unen al resto de seres vivos y por tanto a los lepidópteros como son: comer, beber,

\footnotetext{
${ }^{149}$ http://redescolar.ilce.edu.mx/redescolar/actpermanentes/historia/histdeltiempo/mundo/prehis/ t_evolu.htm (22/1/2.010 a las 11:14h).

${ }^{150}$ Entrevista de Joseph Beuys con Elizabeth Rona, octubre de 1981 publicada en Lamarche Vadel, Bernard. “Joseph Beuys". Op. Cit. Pág. 82.
} 
reproducirse, descansar, protegerse de las inclemencias del clima, de los depredadores y de las enfermedades.

Para cubrir todas estas necesidades, como hemos mencionado anteriormente, el hombre primitivo, que no era capaz de explicar y controlar los fenómenos que ocurrían a su alrededor optó por darles una explicación mágico-religiosa donde las cuevas además de lugar de protección y refugió se convirtieron en lugares sagrados o santuarios donde aparecieron los primeros dibujos creados por el hombre, lo que denominamos arte Paleolítico.

Pero desde esas primeras imágines y grabados representados por el hombre-artista hasta nuestros días el arte ha evolucionado en gran medida, y lo ha hecho paralelamente al desarrollo intelectual, físico y social que el hombre ha sufrido con el paso del tiempo. Ha ido unido a sus sueños, miedos, política, sociedad, dudas, vivencias... Pero el hombre evoluciona y con el también lo hace su arte, ya que como hemos podido comprobar anteriormente, desde su aparición en el planeta el hombre es un hombre-artista, pues el arte nace y morirá con él, como especie.

El hombre primitivo aprende a dominar los metales y esto conlleva grandes cambios en su estilo de vida y sociedad, pero todavía en la Edad de Bronce no ha dejado de lado la creencia de poder controlar las fuerzas naturales, y para ello, realiza rituales y ofrendas a los dioses de las aguas, los montes, del sol... Porque como comenta Mircea Eliade en su libro "Lo sagrado y lo profano": (...) el hombre que opta por una vida profana no logra abolir del todo el comportamiento religioso" ${ }^{\text {"151, }}$, y aunque el ser humano cada vez es más capaz de explicar y prever las acciones de la naturaleza, no puede dejar de lado las creencias y rituales ancestrales.

Como hemos podido comprobar aproximadamente en la década de los 70 , nacen diversos movimientos artísticos que buscan la conexión y los lazos perdidos del hombre con la naturaleza. Tanto en el arte Póvera como en el Land Art, los materiales usados son los encontrados en la naturaleza (hojas, piedras, madera, polen, cera, el fuego, el aire, barro...) son los denominados

\footnotetext{
${ }^{151}$ ELIADE, Mircea. "Lo sagrado y lo profano". Op. Cit. Pág.23.
} 
materiales pobres y los lugares escogidos para la exposición y presentación de sus obras, son naturales, como un camino, un bosque, un río, un campo, un árbol... Desaparece la visión de obras perdurables en el tiempo y lo efímero va ganando terreno en el mundo artístico. Además de los artistas estudiados anteriormente, también hay otros nombres como; Giovanni Anselmo, Mario Merz, Gilberto Zorio, Luciano Fabrio, Walter de María, Michelangelo Pistoletto, Christo, Richard Long, Nils Udo, Robert Smithson, Michael Heizer, Andy Goldsworthy... Se podría decir que es un retorno al hombre primitivo y a su arte natural, donde tanto los soportes, como los pigmentos, los aglutinantes, las ceras, las herramientas eran extraídas o usadas directamente de la naturaleza. Por eso, para nosotros es importantísimo que dentro del arte moderno aparezcan este tipo de movimientos para recordarle al espectador cuál es nuestro verdadero ser y cuál el impuesto.

Podemos decir que la manera y el modo de pensar y realizar experiencias creativas que tenían estos artistas son una de las ideas que están presentes en nuestra visión poética en cuanto a la conexión entre el ciclo vital de la mariposa y el proceso de fundición artística. Para acercarnos más a este pensamiento hemos tratado de dotar de vida al proceso de fundición artística mediante un análisis de los elementos que lo componen.

El siguiente punto a tratar sería la simbología y utilización del elemento fuego. El único elemento que el hombre es capaz de crear por si solo es el fuego, pero no siempre fue así. El hombre primitivo respetaba y temía a este elemento que conocía pero que no era capaz de dominar. Una vez aprendió a crearlo y controlarlo, su mundo inmediato se vio modificado, puesto que, el hombre ya era capaz de calentarse, cocinar sus alimentos, alumbrarse, defenderse...

Según Pilar Crespo: "No es difícil imaginar un grupo de homínidos hace cuatrocientos mil años (...) alrededor de una hoguera. Aprovechando su luz para ahuyentar a las fieras y prolongar el día; y el calor para combatir el frío de la noche, cocinar y descubrir y perfeccionar nuevas técnicas. De esta manera el hogar del fuego se convierte en un lugar donde confluyen todas las 
actividades cotidianas, un lugar de comunicación, un punto mágico y hogar del hombre"152.

El fuego le otorga bienestar y seguridad, necesidades primordiales en la vida del hombre. El sentirse protegido le aporta tranquilidad, descanso y relajación.

Gaston Bachelard nos dice que el fuego encerrado en el hogar fue sin duda para el hombre el primer tema de ensoñación, el símbolo del reposo, la invitación al descanso. No se concibe apenas una filosofía del reposo sin la ensoñación ante los leños que llamean. (...) renunciar a la ensoñación ante el fuego es renunciar al uso verdaderamente humano y primero del fuego. Sin duda, el fuego calienta y reconforta. ${ }^{153}$ Quién no ha observado una hoguera y se ha visto atraído por la belleza de las diferentes tonalidades de la llama, su olor, su humo, su calor y una vez sólo quedan resquicios casi sin "vida" entre sus brasas, seguimos sintiendo atracción por sus cenizas.

El fuego nos otorga paz y tranquilidad, está presente en todos los procesos que se dan en la naturaleza y desde la Antigüedad se le ha otorgado la capacidad de explicarlo todo.

- $\quad$ "El fuego es un fenómeno privilegiado que puede explicarlo todo. Si todo aquello que cambia lentamente se explica por la vida, lo que cambia velozmente se explica por el fuego. El fuego es lo ultra-vivo. El fuego es íntimo y universal. Vive en nuestro corazón vive en el cielo. Sube desde las profundidades de la sustancia y se ofrece como un amor. Desciende en la materia y se oculta, latente, contenido como el odio y la venganza. Entre todos los fenómenos, verdaderamente es el único que puede recibir netamente dos valoraciones contrarias: el bien y el mal. (...) El fuego es bienestar y es respeto. Es un dios tutelar y terrible, bondadoso y malvado. Puede contradecirse: por ello es uno de los principios de explicación universal". ${ }^{154}$

Es uno de los cuatro elementos junto con el agua, el aire y la tierra, aunque como hemos podido ver en el primer capítulo de este proyecto, en Oriente los elementos están clasificados en cinco; agua, tierra, fuego, metal y madera. Cada uno tienen unas cualidades, un sexo, una dirección, un color, un humor, un sabor, un órgano... El formar parte de todo, hace que se encuentre

\footnotetext{
${ }^{152}$ CRESPO RICART, Pilar. Tesis Doctoral "Fundición y proceso: El retorno al origen". Op. Cit. Págs. 53 y 54.

${ }^{153}$ BACHELARD, Gaston. "Psicoanálisis del fuego". Op. Cit. Pág. 29.

${ }^{154}$ BACHELARD, Gaston. "Psicoanálisis del fuego". Op. Cit. Págs. 17 y 18.
} 
presente en todas las acciones de la naturaleza. El fuego se encuentra tanto en el calor de la digestión, durante la gestación, en el deseo, en la envidia, en el amor, en el odio, en el acto amoroso... tiene la capacidad de dar vida y quitarla, por tanto, será tanto temido como idolatrado. Es el agente transformador que decía Heráclito. Para él, el origen de todo era el fuego.

Éste, estará presente tanto en el ciclo vital de la mariposa como en el proceso de fundición artística, ya sea como fuego engendrador, creador, agente transformador, interno o externo, etc.

La ubicación del fuego en el proceso de fundición artística es algo evidente, pues es sabido por todos que el fuego transforma el metal sólido en metal fundido, aunque no por todos es conocida la importancia del fuego en el acabado final del bronce, donde permite y acelera las reacciones para crear las distintas tonalidades. No obstante, no sucede lo mismo con el ciclo vital de la mariposa, donde es necesario tener unos conocimientos precisos sobre este proceso para darse cuenta de la importancia que tienen algunos factores ambientales como son la temperatura, la humedad y la luz para que éste llegue a buen término.

La temperatura es uno de los factores más decisivos porque afecta tanto al crecimiento del embrión-oruga que se encuentra en el interior del huevo como a la oruga cuando se encuentra en el interior de la crisálida, creando periodos de inactividad. Estos periodos pueden ser comparables con los periodos de inactividad del bronce cuando se encuentra almacenado esperando ser utilizado y pasar a su fase activa. El calor consigue despertar a ambos elementos, dando paso a la metamorfosis.

Pero la primera fase de ambos procesos es una de las más importantes por ser un momento de fluidez y fusión de diversos elementos. El líquido amniótico o creador procedente de la disolución de varios nutrientes, marcará el porvenir del producto final. Esa mezcla de nutrientes viene avivada por el fuego, sin él no podrían llevarse a cabo ambos procesos.

Según Bachelard: "Se repite, en todos los campos y sin la menor prueba, que el fuego es el principio de la vida. (...) Un partero, después de un largo 
tratado sobre el desarrollo del embrión y la utilidad de las aguas del amnios, viene a profesar que el agua, ese líquido acarreador de todo alimento en los tres reinos, debe ser animada por el fuego". 155

Este líquido amniótico necesita del calor y la humedad para sobrevivir, o lo que es lo mismo, del fuego y del agua.

En la simbología de los elementos el calor corresponde al elemento activo y masculino que es el fuego, mientras que la humedad corresponde al elemento pasivo y femenino que es el agua. En Oriente, el agua sería el elemento yin (expansivo, tranquilo, femenino...) frente al fuego, elemento yang (concentrado, ardiente, masculino...), pero estos elementos no son contrapuestos, sino que se complementan el uno con el otro.

- "(...) tan pronto como la humedad y el calor se han mezclado en las debidas proporciones, dan lugar a la vida, y de estos dos elementos nace todo, y a pesar de ser el fuego enemigo del agua, es esta húmeda irradiación calorífica lo que produce todas las cosas, y esta discorde concordia resulta apropiada para la reproducción". 156

Sin el fuego creador, el inicio de ambos procesos no podría llevarse a cabo y por tanto, ninguno podría llegar a culminarse. Esta fase pasiva en ambos procesos, da lugar a una fase activa de crecimiento y expansión, de cambio y de movimiento. Este crecimiento viene marcado por el calor interno, del calor presente en la digestión de la oruga y el fuego o calor aplicado a la cera, para reblandecerla, suavizarla y poder modelarla.

- “(..) ese calor íntimo, encerrado, custodiado y poseído que constituye una digestión feliz, conduce inconscientemente a postular la existencia de un fuego escondido e invisible en el interior de la materia, o, como dicen los alquimistas, en el vientre del metal". ${ }^{157}$

Según esta idea, la cera como materia también poseerá ese fuego interior. Por tanto, no es de extrañar que varios autores otorguen a la cera la capacidad de estar viva, debido a su poder de transformación, su compor-

\footnotetext{
${ }^{155}$ BACHELARD, Gaston. "Psicoanálisis del fuego". Op. Cit. Pág. 120.

${ }^{156}$ OVIDIO NASON, Publio. "Metamorfosis I". Editado por el Consejo Superior de Investigaciones Científicas. Madrid, 1.992. Pág. 24.

${ }^{157}$ BACHELARD, Gaston. "Psicoanálisis del fuego”. Op. Cit. Pág. 127.
} 
tamiento frente a los factores externos; calor, humedad, etc. Así, encontramos que la cera y el fuego, principales componentes del proceso de fundición artística, han dejado de ser inertes, para transformarse en materia viva. Más adelante veremos cómo el metal también es considerado "vivo" por los alquimistas que creían que los minerales y los metales eran los embriones de la Madre Tierra, y crecían dentro de ella.

Además el fuego simbólicamente va unido a la vida, muerte y resurrección, por tener la capacidad de crear vida, quitarla y purificarla, al igual que la abeja y la mariposa. Es el calor vital, la destrucción y la purificación del alma. Debido a la creencia de que el fuego otorga la salvación y purifica el alma, en algunas culturas se realizaban ceremonias fúnebres que consistían en quemar a sus muertos.

Un ejemplo de sacrificio y ascensión espiritual después de la muerte por el fuego, la podemos encontrar en el escrito de George Sand: “¿Por qué no poseo los ojos de una hormiga para admirar este abedul abrasado?; jcon qué transportes de ciega alegría y de frenesí de amante, estos enjambres de diminutas mariposas blanquecinas vienen a precipitarse en él! ¡He aquí el volcán en toda su majestad! He aquí el espectáculo de un inmenso incendio. Esta luz deslumbrante las embriaga y las exalta, como haría conmigo la visión de todo el bosque incendiado". ${ }^{158}$. Esta idea la completa Bachelard con su propia visión personal: "El amor, la muerte y el fuego han sido unidos en el mismo instante.

Mediante su sacrificio en el corazón de la llama, la mariposa nos da una lección de eternidad. La muerte total y sin rastro es la garantía de que partamos enteramente al más allá". 159

Como podemos observar el fuego no sólo está presente y es uno de los elementos más importantes en el proceso de fundición, como en un primer momento se podría pensar, sino que se encuentra presente en todos los procesos naturales, en la materia y en todos los seres vivos.

\footnotetext{
${ }^{158}$ SAND, George. Citada por GASTON, Bachelard en “Psicoanálisis del fuego". Op. Cit. Págs. 33 y 34.

${ }^{159}$ GASTON; Bachelard. "Psicoanálisis del fuego". Op. Cit. Pág. 34.
} 
La simbología y el uso del fuego por parte del hombre primitivo como hemos comentado anteriormente, fue evolucionando a la vez que él también lo hacía. En sus inicios, su función era la cocción de alimentos, ahuyentar a los depredadores, calentarse, ampliar las horas de visibilidad, etc. pero una vez el hombre fue capaz de controlar y dominar el fuego, pronto aprendió a trabajar los metales. A este periodo se le ha denominado Edad de los Metales y lleva por nombre el metal más utilizados en casa época. Nosotros nos centraremos en la Edad de Bronce. Según la opinión de María Cruz Fernández; "Pocas contribuciones a la historia de la Humanidad han tenido tanta transcendencia en el dominio de la naturaleza como la adquisición de los medios materiales y técnicos para producir objetos de bronce (...) La experimentación con el metal (...) es un proceso de larga duración que obligó a la realización de múltiples ensayos". ${ }^{160}$

Los orfebres y metalúrgicos son los encargados de realizar estos trabajos y como el bronce era considerado un metal noble, todas las familias pudientes querían poseer objetos de metal acorde con sus riquezas y sus ambiciones.

Pero también hay una vertiente destinada a temas religiosos. Los depósitos de objetos metálicos eran ofrendas o donativos a las divinidades naturales, con el fin de evitar inclemencias del tiempo, malas cosechas...

Como hemos podido comprobar, el proceso de fundición artística ha sido utilizado por el hombre desde hace más de 5000 años.

\footnotetext{
${ }^{160}$ FERNÁNDEZ, María Cruz. "Historia del arte. La Edad de los Metales”. Ed. Historia 16. Madrid, 1989. Pág. 8.
} 


\section{Se hizo el bronce}

"Se hizo el bronce para ser carne inmortal

y fuego de pasiones anudadas al destino

contra las cenizas del tiempo.

Se creó para darle un cuerpo a los dioses,

para que se cumplieran sus designios

y tú, oh mortal, supieras de la eternidad.

Yacían los metales enterrados

hasta que un fuego prometeico los despertó

y alguien los transformó para ti.

Quien volviera poder a tejer las estatuas divinas

y elevar nuevas columnas con el humo de la piedad

mientras las libaciones se derraman

$y$ vuelve a la tierra el fruto de la tierra.

El mar devuelve a veces lo que ya no nos pertenece:

sucios trozos de bronce

sumergidos en una noche". ${ }^{161}$

\footnotetext{
${ }^{161}$ http://www.adapse.com/texto/poemas.html (31/3/2.011 a las $\left.11^{\prime} 03 h\right)$. Espada, Javier. "Se hizo el bronce". 
En la Edad de Bronce, ya se utilizaba el proceso de fundición a la cera perdida y algunos trabajos se realizaban martilleando láminas de metal hasta obtener la forma deseada.

Como hemos comentado anteriormente, el metal en Oriente forma parte de los cinco elementos fundamentales o cinco regiones del cielo junto al agua, la tierra, el fuego y la madera.

Según Hans Biedermann: “(...) la imagen asiático-oriental del mundo, elaborada en la antigua china, parte de los principios primarios yin y yang y que no conoce solamente cuatro, sino cinco regiones del cielo (...) Los elementos son aquí agua, madera, fuego, tierra y metal. Un antiguo verso mnemotécnico dice: «El agua crea la madera, pero destruye el fuego; el fuego crea la tierra, pero destruye el metal; el metal crea el agua, pero destruye la madera; la madera crea el fuego, pero destruye la tierra; la tierra crea el metal, pero destruye el agua»". 162

En este verso podemos comprobar cómo la tierra crea el metal, por tanto no es de extrañar que los alquimistas otorguen a la Madre Tierra un carácter sagrado y al mineral la capacidad de estar vivo. Pero no son los únicos, pues Giuseppe Penone en su serie de obras "Gesti vegetali", también le otorga al metal una ligereza, un ritmo, una calidez, un movimiento, una vivacidad que nos aleja en gran medida de esa imagen fría, eterna, sólida... que normalmente acompaña al bronce. Además no hay que olvidar que como hemos visto en capítulos anteriores, para él, la madera, el metal, la piedra, aunque materiales clasificados como eternos o duraderos por otros artistas, se convierten en fluidos, efímeros, blandos. Todo depende de la manera del artista de percibir y entender el paso del tiempo, porque todo está, en constante cambio y movimiento aunque algunas transformaciones sean casi imperceptibles a nuestros ojos por llevar un ritmo de desgaste y erosión más ralentizado que el nuestro.

Esa manera de percibir la vida, de "fluir" con lo que nos rodea, como hemos podido ver a lo largo de la tesis es transmitida a su obra y por tanto, el

\footnotetext{
${ }^{162}$ BIEDERMANN, Hans. “Diccionario de Símbolos”. Ed. Paidós. Barcelona, 1.996. Pág. 164.
} 
proceso artístico empleado para la realización de sus obras, estará impregnado de "vida" ya que es el camino a través del cual se comunica con su obra.

Giuseppe Penone ha creado una serie de esculturas que son, y forman parte de la naturaleza. Son como seres del bosque, llenos de vida.

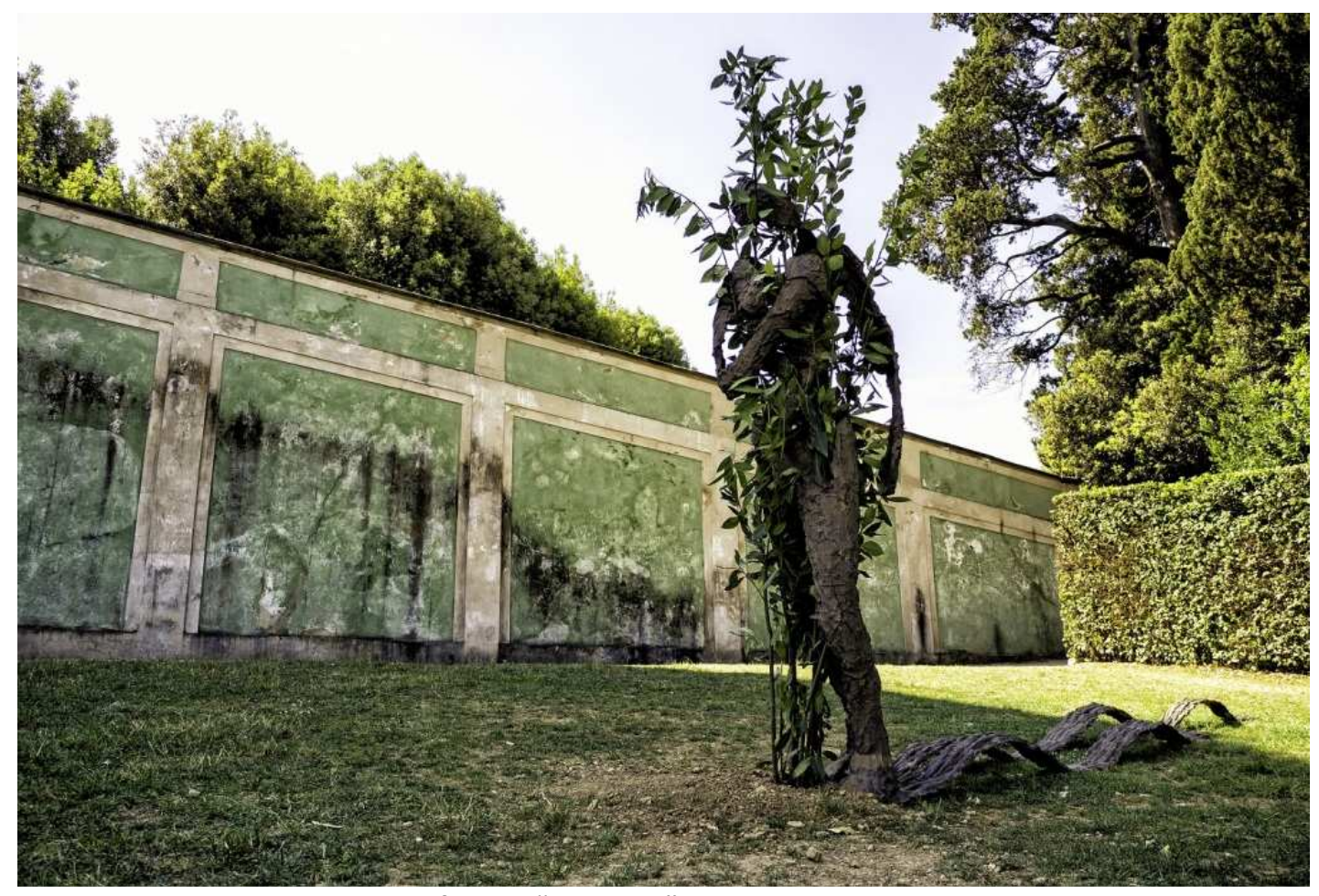

Ilustración 65. "Sentiero". Giuseppe Penone.

Guy Tosatto en el catálogo del C.G.A.C. de Giuseppe Penone, menciona la Génesis del universo para explicar cómo los tres estados del mundo visible conservan la memoria de ese estado original.

- “...) la génesis del universo. Génesis, o más bien aquel momento de la creación en el que todos los elementos que la componían aún estaban fundidos, confundidos en una misma y única sustancia, en un mismo Todo (...) constituía una materia maleable, fluida y viva. Las tres categorías del mundo visible conservan la huella de este estado original. Por consiguiente, se puede deducir que hay algo de mineral $y$ vegetal en lo animal y recíprocamente algo de animal $y$ vegetal en lo mineral". 163

${ }^{163}$ TOSATTO, Guy en VV.AA. “Giuseppe Penone, 1.968-1.998: 22 xaneiro-4 abril 1999”. Op. Cit. Pág. 285. 
Basándose en esta idea Penone otorga la misma importancia en sus obras, tanto al metal, como a la piedra, como a una calabaza, unas patatas, unas ramas... De este modo el metal, aunque ahora podamos percibirlo como un material sólido, frío y eterno, en un momento dado pudo estar dotado de vida.

Para los alquimistas el metal siempre ha estado vivo, ya que se ha formado en el interior de la Madre Tierra.

- “...) si las fuentes, las galerías de las minas y las cavernas son asimiladas a la vagina de la Madre Tierra, todo cuanto nace en su "vientre» está aún vivo, bien que en estado de gestación. $O$ dicho de otro modo: los minerales extraídos de las minas son, en cierto modo, embriones: crecen lentamente, con un ritmo temporal distinto al de los animales y vegetales, pero crecen, <<maduran>> en las tinieblas telúricas". 164

Para los alquimistas, como hemos podido ver anteriormente, el metal y el mineral están vivos en cuanto los engendra la madre naturaleza y además llegan a ser clasificados como embriones en gestación. Por tanto, la extracción de cualquiera de ellos, es una especie de parto de la Madre Tierra. Por tanto, a los minerales y a los metales se les adjudica la capacidad de ser gestados, de nacer, de crecer, de madurar, de sufrir, de morir, de renacer e incluso de su matrimonio (aleaciones).

Todos estos procesos vienen avivados por el fuego, y a éste se le otorgan propiedades espirituales y divinas. De este modo, a los materiales principales en el proceso de fundición artística; la cera y el metal, sean en estado sólido o fundido, se les otorga la capacidad de estar vivos, de ser obedientes y dejarse moldear.

Debido a estos dos materiales existe una conexión en el proceso de fundición entre lo frío y lo caliente, lo orgánico y lo inorgánico, lo natural y lo artificial, lo efímero y lo duradero, el mundo animal y el mineral. Una vez dotados de vida los elementos principales en el proceso de fundición artística (la cera, el fuego y el metal), el siguiente paso en la conexión poética de ambos procesos es la comparativa entre la crisálida y el hueco del molde.

\footnotetext{
${ }^{164}$ ELIADE, Mircea. “Herreros y Alquimistas”. Op. Cit. Pág. 41.
} 
Para ello, comenzaremos por la cueva como lugar mágico y místico y la importancia que ésta tuvo para el ser humano.

- 'La cueva, gruta o caverna tiene un significado místico desde los primeros tiempos (...) como abismo interior de la montaña, es el lugar donde lo numinoso se produce o puede recibir acogida. Por ello, desde la prehistoria, y no sólo por la causa utilitaria de esconder y preservar las imágenes, se situaron en grutas profundas las pinturas simbólicas de los correspondientes cultos y ritos". ${ }^{165}$

Como hemos mencionado en apartados anteriores las cuevas eran el lugar escogido por los hombres primitivos como soporte para su arte. Las cuevas se convertían en un lugar sagrado, una especie de santuario o templo. La cueva era el lugar escogido para estas representaciones porque además de darles protección y cobijo, en las zonas más profundas donde sólo unos pocos se atreverían a entrar por su oscuridad y aislamiento, se creaba un aura de misterio, misticismo y magia. Era el poder y el temor a lo desconocido.

Pilar Crespo, en su Tesis Doctoral, escribe al respecto de la cueva: "La cueva como geografía física, como hueco sobre la tierra o en la tierra, natural o artificial es un espacio complejo y sugerente. (...) Engloba la dualidad complementaria y contradictoria de todo gran símbolo: positivo-negativo, dentro-fuera, arriba-abajo, cielo-tierra, macrocosmos-microcosmos, Dios-hombre, llenovacío, vida-muerte, luz-oscuridad espacio-tiempo". 166

La simbología de la cueva va unida tanto al proceso de fundición artística como al ciclo vital de la mariposa. En el momento preciso en que el interior del molde cerámico se encuentra vacío porque ya se ha realizado el descere y la cocción del molde y la oruga se ha resguardado en el interior de su crisálida para realizar su metamorfosis, se crea un lugar místico y mágico. Un lugar oculto, aislado, fuerte, protector pero a la vez vulnerable, un espacio que se nos niega a la vista y a su vez nos ofrece toda su riqueza.

- "El espacio que queda entre los límites es el vacío que estos definen. En este proceso el hueco del molde que alojará el metal es en potencia una forma y en acto esta misma forma vacía. El espacio de los huecos es inquietante, sugerente, dual. (...) La ausencia de luz produce una sensación de irrealidad y trastoca las nociones

\footnotetext{
${ }^{165}$ CIRLOT, Juan-Eduardo. “Diccionario de símbolos". Ed. Labor. Barcelona, 1991. Pág. 161.

${ }^{166}$ CRESPO RICART, Pilar. Op. Cit. Pág. 44.
} 
de espacio y tiempo. (...) La percepción alterada del espacio interior se refuerza con la distorsión temporal (...) La desorientación espacio-temporal provocada por la falta de referencias propicia situarse en el estado de ensoñación que facilita percibir e imaginar una nueva realidad.(...) Los moldes son como las conchas, los caparazones o cáscaras, que protegen y potencian lo que guardan en su interior. Son las vainas donde sufre su metamorfosis la crisálida. (...) Es en potencia algo invisible mientras permanezca vacío. Posee la fuerza de las cosas frágiles que pueden ser eternas. Es mágico, ambiguo, misterioso, arriesgado, frágil. Hemos construido una vasija, un habitáculo, una concha, una cáscara, el hueco que enterramos para que en el germiné la forma (...) Hemos conseguido un molde preñado de naturaleza". ${ }^{167}$

Casi todas estas cualidades se pueden aplicar tanto al molde cerámico hueco, como a la crisálida aunque la oruga se encuentre dentro realizando su metamorfosis, pues no se trata del ser vivo que en ella se encuentra, sino del lugar que la envuelve y la protege.

La crisálida y el molde cerámico hueco, se transforman en hogar. fuego que está presente en el hogar, nos otorga bienestar y protección porque nos calienta, nos reconforta, nos permite soñar, reposar... De la misma manera que las cuevas ofrecieron protección al hombre primitivo que las utilizó como refugio para resguardarse de los depredadores y de las inclemencias del tiempo.

Esta relación de la crisálida con el hogar, no es nueva, pues la podemos encontrar en el libro "La poética del espacio" de Gaston Bachelard, donde podemos leer cómo la palabra crisálida es una piedra de toque que no engaña. En ella se reúnen dos sueños que hablan del reposo del ser y de su impulso, la cristalización de la noche y las alas que se abren al día. (...) Así, la casa soñada debe tenerlo todo. Debe ser, por muy vasto que sea su espacio, una cabaña, un cuerpo de paloma, un nido, una crisálida. (...) Pero una vez más, nido, crisálida y vestido, no forman más que un momento de la morada. Cuanto más condensado es el reposo, cuanto más hermética es la crisálida, cuanto en

\footnotetext{
${ }^{167}$ CRESPO RICART, Pilar. Op. Cit. Págs. $43,44,47$ y 48.
} 
mayor grado el ser que sale de ella es el ser de otra parte, más grande es su expansión. ${ }^{168}$

Pero no hay que olvidar que esto corresponde a un momento concreto dentro de ambos procesos: el tiempo que transcurre mientras la oruga se convierte en mariposa y mientras la cera desaparece del molde y deja paso al metal fundido.

El resultado en ambos casos no se verá hasta que la mariposa emerja de la crisálida y el escultor rompa el molde cerámico una vez solidificado el bronce. El resultado será un ser u obra nueva que nada tiene que ver con la anterior, ambos han sufrido una metamorfosis. El lugar que ocupaban tan sugerente y místico deja de importarnos, desaparece y todo es nuevo, sorprendente y desconocido.

Como ya hemos mencionado al fuego se le otorga la capacidad de estar vivo, también se le atribuye la simbología de la muerte y la resurrección, por crear vida, quitarla y purificarla. Pero no es el único elemento que aparece en ambos procesos al que se le atribuyen estas propiedades. También se relaciona de una manera simbólica con el ciclo vital de la mariposa. Y la abeja también es símbolo de vida, muerte y resurrección en diferentes culturas.

Las abejas son las creadoras de la cera. Ésta es uno de los componentes principales en el proceso de fundición artística. Para el cristianismo la imagen de la abeja hace mención a Cristo, debido a que este animal sufre procesos de inactividad en el invierno los cuales se relacionan con la muerte y al retomar su actividad normal en tiempos más cálidos, se relacionan con la resurrección.

Un rito gallego llamado el rito funerario del Abellón, estaba basado claramente en estas creencias. Este rito según nos describe Eladio Rodríguez González es una costumbre funeraria gallega: a danza do abellón, hoy seguramente desaparecida.

\footnotetext{
${ }^{168}$ BACHELARD, Gaston. "La poética del espacio". Op. Cit. Págs. 103 y 104. 
- "O abellón: antigua costumbre popular, conocidísima en varias comarcas gallegas, que se relaciona con el viejo culto de los muertos y en la tradición que considera a la abeja como personificación del alma inmortal. Antes de dar sepultura a una persona fallecida, los deudos y amigos del finado entran en el aposento donde se halla el cadáver, $y$, cogidos de las manos, dan vueltas en torno al muerto, imitando al propio tiempo con la boca el zumbido del "abellón". El que toma parte en esta especie de danza fúnebre y deja antes de tiempo, de dar vueltas o de simular el monótono rumor de aquel insecto, está llamado a muerte próxima, según vulgar creencia". 169

Debido a la simbología de la abeja y del fuego, que están presentes en el proceso de fundición artística podemos crear una conexión entre ambos procesos, pues el ciclo vital de la mariposa para el mundo cristiano representa esta misma simbología, vida, muerte y resurrección. Entre los antiguos tanto la abeja como la mariposa servían para representar el alma. La fase oruga hace referencia a la vida (fase activa), la fase crisálida hace referencia a la muerte (fase inactiva), y por último la fase mariposa hace referencia a la resurrección o la salvación (fase activa).

- "Por pasar de oruga a mariposa es símbolo de resurrección o de la salida de la tumba. Para los aztecas representaba el alma o el aliento vital que escapa de la boca del agonizante: una mariposa jugando entre unas flores representaba el alma de un guerrero caído en los campos de batalla.

Así mismo, los guerreros muertos acompañaban al sol en la primera mitad de su curso visible, hasta mediodía: en ese momento volvían a descender a la tierra en forma de colibríes o mariposas." 170

El hombre cristiano siempre ha visto reflejadas en la abeja y la mariposa sus creencias espirituales, pues una vez muerto el ser humano ascenderá a los cielos dejando el mundo terrenal.

En un bello poema de Antonio Machado podemos comprobar cómo la miel, la abeja, la cera y el calor del sol, nos acercan a Dios.

\footnotetext{
${ }^{169}$ http://www.sea-entomologia.org/PDF/BOLETIN_12/B12-013-031.pdf (28/5/2.009 a las 10'58h).

${ }^{170}$ http://www.museodebogota.gov.co/descargas/publicaciones/pdf/Glosario_funerario.pdf

$\left(27 / 5 / 2.009\right.$ a las $\left.11^{\prime} 16 \mathrm{~h}\right)$.
} 
Anoche cuando dormía...

[Poema: Texto completo.]

Antonio Machado

Anoche cuando dormía

soñé, ibendita ilusión!,

que una fontana fluía

dentro de mi corazón.

Di, ¿por qué acequia escondida,

agua, vienes hasta mí,

manantial de nueva vida

de donde nunca bebí?

Anoche cuando dormía

soñé, ibendita ilusión!,

que una colmena tenía

dentro de mi corazón;

y las doradas abejas

iban fabricando en él,

con las amarguras viejas

blanca cera y dulce miel.

Anoche cuando dormía

soñé, ibendita ilusión!,

que un ardiente sol lucía

dentro de mi corazón.

Era ardiente porque daba

calores de rojo hogar,

y era sol porque alumbraba

y porque hacía llorar.

Anoche cuando dormía

soñé, ibendita ilusión!,

que era Dios lo que tenía

dentro de mi corazón. ${ }^{171}$

\footnotetext{
${ }^{171}$ http://www.ciudadseva.com/textos/poesia/esp/machado_a/anoche_cuando_dormia.htm (10-07-2015 a las 12:05h) 
Las conexiones poéticas entre ambos procesos continúan con los posibles defectos en el bronce final y los posibles defectos físicos en las mariposas.

Aunque el proceso de fundición artística ha ido evolucionando desde sus inicios a nuestros días, los defectos de las piezas de fundición, no han podido ser eliminados por completo. Basta con un fallo mínimo en cualquier fase del proceso de fundición artística para que éste no llegue a buen término.

Podemos errar a la hora de mezclar los componentes iniciales para la elaboración de una "cera" perfecta para el modelo, o en la manera de aplicarle los baños, en el momento del descere o la cocción de la pieza, e incluso en el mismo momento de la colada, el resultado es el mismo, una pieza dañada con unos defectos físicos, que pueden ser tanto internos como externos. Si llegados a este punto recordamos la creencia de los alquimistas, de que los minerales y metales estaban vivos y crecían en el interior de la Madre Tierra, no es de extrañar que al igual que el ser humano, también estén expuestos por su naturaleza a sufrir deformaciones y defectos físicos, si no se les cuida y se les proporciona todo lo que necesitan, para madurar sin problemas.

Este hecho crea una unión entre el proceso de fundición artística y el ciclo vital de la mariposa, en cuanto las mariposas como cualquier ser vivo, pueden nacer con ciertas deformidades físicas o con problemas internos de mayor o menor importancia.

Tras la emersión de la mariposa de la crisálida, ésta tiene que extender sus alas en posición invertida para dejarlas secar al sol, evitando cualquier deformación física visible y poder volar posteriormente.

Ivo Novák, en su libro "Mariposas", comenta lo siguiente: "la variabilidad de los individuos, poblaciones y especies difiere en el grado o medida de sus características. En el caso de mariposas y polillas, las desviaciones más notables (aunque no siempre las más útiles) son naturalmente variaciones en el color y el dibujo de las alas. Se dice que las mariposas y polillas aparecen de varias formas. En general, son formas individuales (también llamadas aberraciones) y no son hereditarias. Otras desviaciones tienen lugar en forma 
de mutaciones y son permanentes, siendo transmitidas a la descendencia según las leyes de la herencia genética". ${ }^{172}$

La humedad, la temperatura, la calidad de los nutrientes son los factores que más contribuyen a que aparezca algún problema físico en las mariposas. Estos pueden ser: cambios en el dibujo o color de sus alas, su tamaño o forma, etc.

El bronce fundido por su parte, una vez alojado en el interior del molde cerámico se encuentra a gran temperatura y debemos dejarlo enfriar y solidificar antes de romper el molde para evitar posible defectos en la pieza y que ésta sea lo más fiel posible en su registro.

Pero no es sólo en este momento del proceso donde hay que ser precavidos, como ya hemos mencionado, hay que serlo durante toda la duración del mismo. Para obtener buenos resultados tanto en fundición artística como en cualquier otro proceso artístico, es necesario ser buenos conocedores del proceso antes de llevarlo a cabo, posteriormente con la práctica se irá perfeccionando.

- "(...) si no se toman ciertas precauciones durante el moldeado, la colada o el desmoldeado, las piezas que se obtienen pueden quedar deformadas, incompletas, parcialmente llenas, o por causa de tensiones internas, tener demasiada fragilidad o por lo menos tendencia a deformarse. En todos los casos enumerados anteriormente, las piezas presentan defectos de integridad o de forma". ${ }^{173}$

Estos defectos pueden ser: faltas, rechupes, grietas, tensiones internas, deformidades, roturas, no-llenados, uniones frías, arrugas o pliegues, etc. Para verificar las lesiones internas de las piezas de fundición es necesario realizarles un diagnóstico radiológico, lo cual las dota de un carácter más humano.

Para finalizar nos introduciremos en el mundo del color de la naturaleza mediante las pátinas en bronce y las alas de las mariposas.

Una vez el producto final existe, sea una mariposa o una pieza en bronce, el color entra en juego de una manera sorprendente, siendo una de sus

\footnotetext{
${ }^{172}$ NOVÁK, Ivo. “Mariposas”. Op. Cit. Pág. 15.

${ }^{173}$ Le BRETON, H. "Defectos de las piezas de fundición". Ediciones Urmo. Bilbao, 1975. Pág. 20. 
características más notorias. Los factores externos como hemos comentado con anterioridad, o los nutrientes iniciales afectan a ambos procesos produciendo diferentes colores y tonalidades. Algunas especies de mariposas poseen elaborados y complejos dibujos en sus alas, con una amplia gama de colores, tonalidades y destellos metálicos:

- "Los elaborados dibujos de las alas están formados por diminutas escamas que o bien contienen pigmentos o producen colores físicamente por difracción y refracción de la luz, dando con ello a las alas su llamativo esplendor". ${ }^{174}$

En cuanto al metal, el color que podemos ver en su superficie recibe el nombre de pátina. Éste, al igual que a la mariposa, le otorga al bronce belleza y majestuosidad. Estos colores se pueden obtener estando la pieza fría o caliente, aunque normalmente se obtienen bien por cambios bruscos de temperatura en el metal, como puede ser la causa de la obtención de la gama de rojos, o por aplicación en la superficie de la pieza de una serie de disoluciones químicas, que, al aplicarle calor mediante un soplete, harán reaccionar la superficie del bronce y obtendremos la gama de azules, verdes y marrones o negros.

La gama de color que se puede obtener al realizar la pátina en bronce es muy amplia, pero los colores más usados suelen ser los ya mencionados, rojos, verdes, negros y azules. Los rojos se forman mediante un cambio brusco de temperatura, esto se consigue como hemos comentado anteriormente, calentando la pieza hasta el rojo vivo y a continuación echarla en agua fría o sumergirla rápidamente en arena de sílice (aleación 85-5). El nitrato de hierro, puede dar tonalidades amarillas, rojas y negras.

Por tanto, la humedad, la luz y los cambios bruscos de temperatura otorgan al bronce su color, al igual que ocurre con la mariposa. Llegando incluso a deteriorarlo con el paso del tiempo.

\footnotetext{
${ }^{174}$ NOVÁK, Ivo. “Mariposas”. Op. Cit. Pág. 13.
} 
Fragmento del poema de Pablo Neruda

\author{
"Esta campana rota..." \\ El bronce roto y verde, \\ la campana de bruces \\ y dormida \\ fue enredada por las enredaderas, \\ y del color oro duro del bronce \\ pasó a color de rana: \\ fueron las manos del agua, \\ la humedad de la costa, \\ que dio verdura al metal, \\ ternura a la campana. ${ }^{175}$
}

Toda esta gama de colores presente en el bronce también podemos encontrarla en las alas de las mariposas, pues los colores de pigmento presentes en las escamas suelen dar tonalidades verdes, aunque también rojas y amarillas. Si los colores vienen dados por refracción o difracción de la luz mediante las escamas presentes en sus alas, los colores resultantes, suelen ser tornasolados generalmente azules. También el color negro está presente en las alas de las mariposas, sobre todo en aquellas que utilizan el contraste entre el rojo, negro y amarillo como colores de advertencia ante los depredadores.

Si la mariposa pierde las escamas que recubren sus alas por cualquier motivo, por ejemplo por el contacto con la piel de un ser humano, la impronta de nuestro dedo quedará marcada en la mariposa para siempre, pues al perder las escamas de esa zona, también pierde su colorido en ella y se vuelve transparente.

Algo muy similar tiene lugar en la pátina en bronce, pues si los ácidos son aplicados por el artista mediante pinceles o brochas la pieza recibirá la

\footnotetext{
${ }^{175} \mathrm{http}: / /$ www.poemas-del-alma.com/pablo-neruda-esta-campana-rota.htm (10/07/2015 a las $12: 56 h)$
} 
impronta del escultor, es decir, una vez terminada la obra se podrá ver en ella la huella de esas herramientas y la manera y fuerza con que el artista ha aplicado la pátina en ella.

- "Tanto los bronces, como los cobres y los metales en general son sumamente sensibles a la acción de los ácidos, el agua y el aire. El resultado de las pátinas depende de la aleación del bronce y del método de aplicación". ${ }^{176}$

Nos gustaría dejar a un lado la teoría del color del bronce, para centrarnos en una de las visiones más románticas y poéticas de la pátina de este metal noble que hemos podido leer a cargo del artista Giuseppe Penone.

- "Es el bronce que con gran facilidad traduce, fosiliza el vegetal, el gesto de su crecimiento y el color de sus humores.

Admiramos el paisaje de la pátina del bronce que no es ni óxido ni color, sino que exuda del metal con la misma frescura natural de los verdes, grises, rojos de los musgos y de los follajes.

El metal sufre los elementos del aire, la lluvia, el viento, el calor del sol y de ellos, como en los vegetales se forma su color. El aire denso y compacto en perpetua tensión mordiente y sutil penetra en el bronce y le corroe, le comprime, hace aparecer (florecer) en su superficie el brillante esplendor del paisaje". ${ }^{177}$

Según esta idea, el bronce deja de ser un metal frío para transformarse en algo cálido, deja de ser inorgánico para transformarse en orgánico, deja de ser mineral para dejar paso a su parte vegetal y animal. Este acercamiento a la naturaleza nos acerca también a la mariposa, la cual, aunque animal, también posee parte vegetal y parte mineral. Todas las cosas, formamos parte de un Todo, por tanto, la mariposa puede ser mineral en cuanto el mineral puede ser mariposa.

\footnotetext{
${ }^{176}$ ACOSTA, Fátima en VV.AA. “La fundición artística en la universidad española: La investigación, año 2006". Edita Grupo de Investigación nuevos Procedimientos Escultóricos. Valencia, 2007. Pág. 28.

${ }^{177}$ PENONE, Giuseppe, citado en CRESPO RICART, Pilar. "Fundición y proceso: El retorno al origen". Op. Cit. Pág. 79.
} 

6. Conclusiones 
Como hemos comentado anteriormente, esta tesis, era una ampliación de nuestro trabajo de investigación donde realizábamos una analogía poética entre el ciclo vital de la mariposa y el proceso de fundición artística a la cera perdida. La tesis partía de una idea que nació en el taller de fundición artística tras la observación, contemplación y participación activa en este proceso creativo. La energía, la fuerza, el color incandescente del metal fundido en el momento de la colada, nos acercaba a la figura del alquimista alrededor del crisol. Se creaba un momento mágico y espiritual, el espacio se llenaba de energía, de fuerza, de "vida". En el momento de la colada en bronce nos dimos cuenta, que la visión fría, sólida, pesada y eterna que poseíamos del bronce desaparecía para dejar paso a una imagen cálida, vivaz, ligera, fluida y atemporal, era como estar presenciando algo vivo. Este cambio conceptual se podía llevar a cabo gracias a ese proceso creativo que le otorgaba la energía necesaria para esa transformación. Por tanto el proceso de fundición artística bajo nuestra visión personal, poética y subjetiva, se transformaba en un proceso cargado de naturaleza debido tanto a los elementos principales que lo componen, el fuego, la cera y el metal, como por el ser natural que lo realiza que es el hombre-artista. La tesis como hemos podido comprobar se basa en la ampliación de esa visión del hombre-artista como una especie más de la naturaleza y formando parte de un Todo. El hombre como ser plástico, imaginativo y creativo desde su aparición en el planeta. El planteamiento de nuevas maneras de entender el arte basándonos en la relación entre el hombre-artista y su obra. Dotar de vida a la obra de arte, puesto que en ella residen las experiencias, emociones, miedos, vivencias... del ser que las realiza, son la prolongación del hombre-artista. Y por último, convertir los procesos creativos en un camino de unión y comunicación entre el hombre-artista y su obra, transformándolos en conductores de ilusiones, ideas, sensaciones...

Una realidad que actualmente se encuentra, como hemos comentado a lo largo de toda la tesis, en vías de extinción es ver al ser humano como una especie más de la naturaleza. Lo que nos equipararía y nos hermanaría con el resto de seres vivos del planeta. Esto es tan sencillo de comprender como que; si el agua se contamina, si algunas especies desaparecen, si se siguen talando 
árboles de forma masiva, si seguimos contaminando el aire, malgastando los recursos naturales... no sólo está sufriendo la naturaleza, nosotros también sufrimos las consecuencias. No somos mejores ni peores, sólo es que hemos perdido el respeto por nuestro entorno a lo largo del camino, pero nunca es tarde para retroceder y darse cuenta de que esa felicidad tan ansiada por el ser humano está más cerca de lo que imaginamos, sólo hay que dejar de mirar para ver en profundidad el problema que nos atañe y darnos cuenta de que esta vida que llevamos donde el tiempo corre tan deprisa, basada en la razón y el presente apenas existe de manera consciente, no nos deja espacio para valorar los pequeños detalles y los pequeños logros conseguidos cada día y eso nos crea decepciones y nos hace infelices. Creemos tener la capacidad de escoger, cuando nuestro camino viene marcado por el consumo y el antropocentrismo, caminamos hacia un aislamiento con respecto a nuestros sentimientos e instintos, y esto nos aleja de nuestro ser y nos convierte en marionetas de un sistema que sólo piensa en su propio beneficio.

Con este trabajo nos hemos dado cuenta que ser libre, no es poder escoger que comprar o que ropa ponerte, ser libre es sentirse unido a un Todo, no dejarse llevar únicamente por nuestro ego, ni por nuestra mente, hay que dejar que de vez en cuando nuestro "espíritu" o "alma" también coja las riendas y nos permita realizar acciones, en nuestro caso como artistas, que nos permita hacer obras donde nos fundamos en ellas, que el espacio-tiempo desaparezca y que en ese momento sólo seamos obra.

Creemos que los artistas que verdaderamente han triunfado a lo largo de la historia, da igual la técnica, el estilo, el contenido, la forma... ha sido porque han vivido con tal intensidad ese momento de creación, que la obra queda impregnada de ella y se transmite al espectador. Un ejemplo donde esta idea pensamos se puede apreciar de una manera más clara, es contemplando la obra del artista holandés, Vincent van Gogh. 


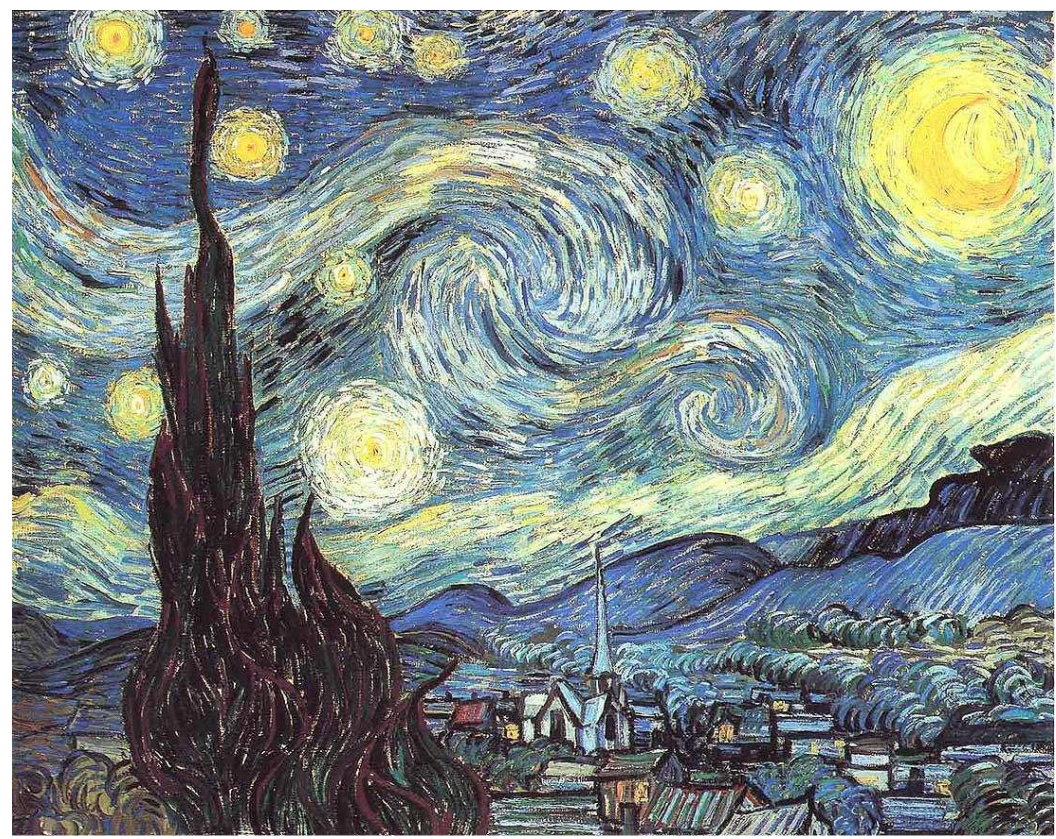

Ilustración 66. Noche estrellada-Starry Night-Vincent van Gogh Museo de Arte Moderno de Nueva York. $189073,7 \times 92,1 \mathrm{~cm}$. Óleo sobre lienzo

Cada pincelada es un reflejo de su pasión, de sus sueños, de su decepción, de sus dudas, de su lucha interior... El espectador no puede en cuanto maravillarse frente a una de sus pinturas, dejando a un lado si estéticamente nos parece más o menos arraigada conforme a nuestros gustos personales, no se trata de entender el arte, se trata de vivirlo.

Puede ser una vivencia trágica o alegre, una rebeldía o un sueño, pero si su "espíritu" se ha fundido con ella, esa obra, no podrá pasar inadvertida, porque es una ventana que nos deja ver el interior del artista, podremos vislumbrar mediante su contemplación, los pensamientos y sentimientos más ocultos, su verdadero ser, su esencia.

El trabajo nos ha acercado a otra realidad del arte como es, el mercado artístico, con coleccionistas, galerías, museos... Esta es la otra cara de la moneda, el arte ha llegado a un punto en el que muchos artistas no crean conforme a su "espíritu", se dejan guiar por las normas de mercado, realizan un arte vendible y productivo que les procure una vida cómoda y el reconocimiento que anhelan. Este tipo de arte, no podrá equiparase con aquel que nace del 
interior del artista y proyecta en su obra todo su ser, porque este, también es el reflejo del artista, pero corroído por la sociedad en la que vivimos, un arte vendido y vacío, sin sentimiento.

Por tanto, a lo largo del trabajo, hemos podido comprobar que el arte es un punto importante dentro de la naturaleza del hombre, pues nos acompaña a lo largo de nuestra vida y existe desde que el hombre apareció en el planeta.

Somos seres creativos y plásticos desde nuestro nacimiento, basta ver a cualquier niño y darse cuenta que su instinto es el de crear, experimentar, plasmar y utilizar los materiales y objetos que estén a su alcance para desarrollar sus pensamientos. En ellos no existe el miedo al fracaso ni al qué dirán, no buscan unos cánones de belleza establecida, sólo buscan expresarse y dejar volar su imaginación, solo buscan ser felices y disfrutar del momento, y en ese instante, son libres.

Estudiando el arte primitivo hemos comprobado que este, estaba unido a los fenómenos naturales y el hombre respetaba la naturaleza. El estudio de las filosofías orientales, el taoísmo y el confucionismo, nos ha trasladado a una visión bastante alejada de la occidental tanto en pensamiento como artísticamente hablando, nos ha ayudado a comprendernos y conocernos a nosotros mismos.

Creemos que es importante tener diversos puntos de vista, y ser conocedores de otras realidades para formarnos como persona, y así ser capaz de ampliar nuestros horizontes.

Tal vez, lo más complicado a la hora de abordar esta tesis haya sido plasmar en papel, toda una serie de ideas, pensamientos, sentimientos, dudas... que estaban alojados en nuestra mente de manera efímera e intangible. Podríamos compararlo con el hecho de dotar de vida la obra de arte, debido a que es una visión más ilusoria para el tipo de sociedad actual.

Esta sufre una transformación igual de importante que cualquier otro proceso natural. La metamorfosis de la obra de arte, comienza en la mente del artista, allí nace una idea, que es efímera, pero que debe de transformarse en algo tangible. Todo el proceso de realización se impregna con la energía, el 
esfuerzo, la ilusión, la decepción... del artista. Además están impregnadas de las vivencias, de los temores, de los recuerdos y sentimientos de su creador.

Por tanto, pensamos que en la tesis se ha podido llegar a comprender la importancia recíproca que tiene la obra y el artista, y también el espectador que se impregna de su esencia.

Hemos podido ver como después de un paso importante como es ver al hombre como naturaleza y la obra de arte como prolongación del artista, era necesario conforme al ser que lo realiza, que es el hombre-artista, abarcar el tema de los procesos creativos que eran la base de nuestro trabajo de investigación. Estos son los medios por los que esa metamorfosis de la obra de arte mencionada anteriormente, se puede llevar a cabo.

En cuanto que la persona que lo realiza (hombre-artista), es naturaleza, y el resultado final está cargado de vida, el proceso artístico se convierte en un conductor, es un camino por el que desfilan los mismos sentimientos, miedos y vivencias que posteriormente se alojarán en la pieza.

Por tanto, hemos ubicado esta comparativa poética entre ambos procesos en el último capítulo de la tesis, por ser la base de la que hemos partido y gracias a ella se ha desarrollado todo nuestro estudio posterior. Creemos que el hecho de dejar volar la imaginación, es importante para todo ser humano, pero en especial para el ser artista, y nosotros nos hemos dejado guiar por ella en la realización de la comparativa entre un proceso natural y un proceso artístico, y los resultados han valido la pena. Nos hemos valido de un estudio por separado de ambos procesos para darlos a conocer al lector de manera más detallada y posteriormente nos hemos podido adentrar en un mundo subjetivo, donde los puntos de conexión aparentemente inexistentes en un principio, han ido cogiendo fuerza conforme estudiábamos y valorábamos los diferentes elementos por separado.

Resumiendo lo dicho hasta el momento, hemos transformado una idea que nacía de la praxis artística y sensitiva propia en una investigación doctoral. Hemos reflexionado sobre el Arte como herramienta de unión con la naturaleza. Hemos dejado a un lado nuestro antropocentrismo y hemos 
reflexionado sobre el ser humano como una especie más de la naturaleza, desde una visión más humilde frente a esta y el resto de seres vivos. Hemos comenzado a valorar el presente como tiempo real y disfrutar de él, sin volcar nuestras aspiraciones con planes a largo plazo o anclados en un pasado que no regresará. También hemos podido observar que, si valoramos los pequeños detalles y los logros de cada día, estaremos más cerca de la felicidad. Hemos planteado una visión más espiritual del arte basándonos en la conexión irrompible entre el hombre-artista y sus creaciones. Hemos dotado de vida a la obra de arte por ser la prolongación del artista y hemos convertido a los procesos creativos en un camino de unión y comunicación entre el hombre-artista y su obra. Hemos establecido entre dos procesos a simple vista dispares como son, el ciclo vital de la mariposa y el proceso de fundición artística a la cera perdida, un gran número de conexiones, creando una analogía poética entre ambos.

Toda la intensidad y energía que el hombre-artista ha puesto en la creación de su obra, el espectador será capaz de sentirla e impregnarse de ella y si somos nosotros mismos y dejamos a un lado nuestras necesidades banales, consumistas, egocéntricas, rencores, celos, envidias... y simplemente vivimos y disfrutamos de la vida, eso sí, de manera respetuosa con todo lo que nos rodea, estaremos más cerca de la libertad que nunca. 

7. Bibliografía general 
ACOSTA, Fátima en VV.AA. "La fundición artística en la universidad española: La investigación, año 2006". Edita Grupo de Investigación Nuevos Procedimientos Escultóricos Ministerio de Educación y Ciencia. Valencia, 2007.

- ALBELDA, José; SABORIT, José. "La construcción de la naturaleza". Edita Direcció General de Promoció Cultural, Museus i Belles Arts. Conselleria de Cultura, Educació i Ciencia. Generalitat Valenciana, 1997.

- AllendesalazAR Olaso, Mercedes. "Spinoza. Filosofía, pasiones y política”. Alianza Universidad (Alianza editorial). Madrid, 1988.

- $\quad$ AVRILLA, Jean- Marc en VV.AA. "Wolfgang Laib, Richard Long, Richard Serra y Lawrence Weiner". Collection du capcMusée <<Exposition sentimentale>> du 26 juin au 30 septembre 1992. Château de Jau. Musée d 'art moderne de Colliure.1992.

- BACHELARD, Gaston. "El agua y los sueños. Ensayo sobre la imaginación de la materia". Edita Fondo de Cultura Económica. México, 1.994.

- BACHELARD, Gaston. "La poética de la ensoñación". Edita Fondo de Cultura Económica. México, 1997.

- BACHELARD, Gaston. "La poética del espacio". Edita Fondo de Cultura Económica. México, 1965.

- BACHELARD, Gaston. "Psicoanálisis del fuego". Ed. Alianza. Madrid, 1966.

- BIEDERMANN, Hans. "Diccionario de Símbolos”. Ed. Paidós. Barcelona, 1996.

- CARTER, David. "Mariposas diurnas y nocturnas". Ediciones Omega. Barcelona, 1993.

- CASÁS, Fernando. "Naturgeist" (Huesca. Arte y Naturaleza). Ed. Diputación de Huesca. 1997.

- CIRLOT, Juan-Eduardo. "Diccionario de símbolos". Ed. Labor. Barcelona, 1991.

- CONFUCIO. "Los cuatro libros". Ed. R.B.A. Barcelona, 2006.

CÓRDOBA LEÓN, Juan Ramón; SESMA MORANAS, José Manuel y MARTíN TORAL, Gabino. "Mariposas en libertad". Ediciones Publimarca. Madrid, 2.006.

- CORREDOR MARTÍNEZ, Juan Antonio. "Técnicas de fundición artística". Ed. Universidad de Granada. Granada, 1999.

- CRESPO RICART, Pilar. "Fundición y proceso: El retorno al origen". Tesis Doctoral. Ed. Universidad Politécnica de Valencia. Valencia, 1997.

- DE MICHELI, Mario. "Las vanguardias artísticas del siglo XX". Alianza editorial. Madrid, 1985.

- DORFLES, Gillo. “Naturaleza y artificio”. Ed. Lumen. Barcelona, 1972.

- ELIADE, Mircea. "El vuelo mágico”. Ediciones Siruela. Madrid, 1995.

- $\quad$ ELIADE, Mircea. "Herreros y alquimistas". Ed. Alianza. Madrid, 1999. 
- ELIADE, Mircea. "Imágenes y símbolos". Ed. Taurus Humanidades. Madrid, 1999.

- ELIADE, Mircea. "Lo sagrado y lo profano". Ed. Paidós. Barcelona, 1998

- FERNÁNDEZ, María Cruz. "Historia del arte. La Edad de los Metales". Ed. Historia 16. Madrid, 1.989.

- $\quad$ FERNÁNDEZ POLANCO, Aurora. “Arte Povera”. Ed. Nerea. Guipúzcoa, 1999.

- FERNÁNDEZ- RUBIO, Fidel. "Guía de mariposas diurnas de la Península Ibérica, Baleares, Canarias, Azores y Madeira". Ediciones Pirámide. Madrid, 1991.

- FUSTER, Joan. "El descrédito de la realidad". Facultad de Bellas Artes de la Universidad Politécnica de Valencia. Valencia, 1999.

- GARCÍA- ORMAECHEA, Carmen. "Las claves del arte oriental". Ed. Ariel, S.A. Barcelona, 1988.

- GOMBRICH, Ernst H. "Historia del arte". Alianza Editorial. Madrid, 1982.

- HAMILTON, Elizabeth. "Desentrena a tu loro. La mente y el camino del Zen". Editorial Edaf, S.I. Madrid, 2010.

- IMPELLUSO, Lucía. "La naturaleza y sus símbolos: plantas, flores y animales". Ed. Electa. Barcelona, 2.003.

- JASPERS, Karl. "Los metafísicos que pensaron desde el origen. Anaximandro, Heráclito, Parménides, Plotino, Anselmo, Spinoza, Lao-Tse, Nagarjuna”. Ed. Tecnos D.L. Madrid, 1998.

- JASPERS, Karl. "Los grandes maestros espirituales de Oriente y Occidente". Editorial Tecnos (Grupo Anaya,S.A). Madrid, 2001.

- JUNG, C.G, BORGES Jorge Luis; WILHELM, Richard; VOGELMANN D.J; WILHELM, Hellmut. "I Ching. El libro de las Mutaciones". Ed. Edhasa: Sudamericana. Barcelona, 2001.Más información: versión del chino al alemán, con comentarios, por Richard Wilhelm ; traducción al español, con presentación y notas, por D.J. Vogelmann ; prólogo de C.G. Jung, Richard Wilhelm y Hellmut Wilhel

- KUSHI, Michio. "El libro de la macrobiótica". Ed. Sol Universal. Málaga. Primera traducción en español, 1979.

- KIM, Sue-Hee. "El arte del Extremo Oriente”. Ed. Anaya. Madrid, 1993.

- LAMARCHE-VADEL, Bernard. "Joseph Beuys". Ediciones Siruela. Madrid, 1994.

- LAO ZI. "Libro del curso y de la virtud: Dao de Jing". Ed. Siruela. Madrid, 1998.

- $\quad$ LAO TZU. "Tao te Ching”. Ed.Azul. Barcelona, 1999.

- LAUER, Mirko. “I Ching”. Barral editores. Barcelona, 1971.

- Le BRETON, H. "Defectos de las piezas de fundición”. Ediciones Urmo. Bilbao, 1975. 
- LEVI-STRAUSS, Claude. "El pensamiento salvaje". Fondo de cultura económica de México. México, 1964.

- LEVI-STRAUSS, Claude. "Mitológicas. Lo crudo y lo cocido I". Fondo de cultura económica de México. México, 1986.

- LOGAN, A, en VV.AA. "Tratado práctico de fundición". Ed. Aguilar. Madrid, 1953.

- LONG, Richard. "Piedras". Ed. Ministerio de Cultura/The British Council. 1986.

- MARCOS MARTíneZ, Carmen. "Fundición a la cera perdida: Técnica de la cascarilla cerámica". Tesis Doctoral. Ed. Universidad Politécnica de Valencia. Valencia, 2001.

- MARTínEZ PARRA, Teresa. "Los materiales orgánicos aplicados a la cascarilla cerámica en el campo de la fundición artística. Proceso y poética". Trabajo de Iniciación a la Investigación. Edita Universidad Politécnica de Valencia. Valencia, 2005.

- MELOTTI, Umberto. "El hombre entre la naturaleza y la historia". Ediciones Península. Barcelona, 1981

- $\quad$ NOVÁK, Ivo. “Mariposas”. Ed. Susaeta. Madrid, 1990.

- OHSAWA, Georges. "Filosofía de la Medicina en Extremo Oriente. El libro del Juicio Supremo". Traducido por Mauricio Waroquiers. Publicaciones Gea. Buenos Aires - Argentina 2005.

- OVIDIO NASON, Publio. "Metamorfosis I". Editado por el Consejo Superior de Investigaciones Científicas. Madrid, 1992.

- PENONE, Giuseppe; Centro Galego de Arte Contemporánea. "Giuseppe Penone, 1968-1998: 22 xaneiro - 4 abril 1999". Centro Galego de Arte Contemporánea". Edita Xunta de Galicia. Santiago de Compostela, 1999.

- PENONE, Giuseppe; Centro Galego de Arte Contemporánea. "Respirar la sombra = Respirar l'ombra". Edita Centro Galego de Arte Contemporánea. Santiago de Compostela, 1999.

- PISCHEL, Gina. "Breve historia del arte chino". Ed. Labor, S.A. Barcelona 1967.

- REICHHOLF-RIEHM, Helgard. “Mariposas”. Ed.Blume. Barcelona, 1990.

- RIPOLL, Eduardo. "Historia del Arte. El arte Paleolítico". Ed. Historia 16. Madrid, 1986.

- SPINOZA. "Tratado de la reforma del entendimiento. Principios de la filosofía de Descartes. Pensamientos metafísicos”. Alianza Ed. Madrid, 1988.

- SPINOZA. "Tratado breve". Alianza Ed. Madrid, 1990.

- STACHELHAUS, Heiner. “Joseph Beuys”. Ed. Parsifal. Barcelona, 1990.

- TOLLE, Eckhart. "El poder del ahora”. GAIA ediciones. Mostoles, 2001.

- VIDAL LÓPEZ, Pere, en VV.AA. "La fundición artística en la universidad española: La docencia año 2006". Edita Grupo de Investigación Nuevos. Procedimientos Escultóricos Ministerio de Educación y Ciencia. Valencia, 2007. 
- VIRGILIO MARÓN, Publio. "Bucólicas/Geórgicas". Ed. Planeta. Barcelona, 1988.

- VV.AA. "Château de Jau. Musée d'art moderne de Collioure. $<<$ Expositon sentimentale>>". Ed. Musée d'art contemporain de Bourdeaux. Bordeaux, 1992

- VV.AA. "Las Bellas Artes. Orígenes del Arte Occidental". Enciclopedia ilustrada de pintura, dibujo y pintura. Volumen 1. Grolier Incorporated. New York, London...1969.

- VV.AA. "The Real Thing" Arte contemporáneo de China. Producción: Tate, 2008. IVAM Institut Valencià d'Art Modern. Valencia, 2008.

- WILHEM, Richard. “Confucio”. Ed. Alianza. Madrid, 1986.

- WONG, Eva. "LIE TSE. Una guía taoísta sobre el arte de vivir". Editorial Edaf. Madrid. 2012. 


\section{PÁGINAS WEB}

- www.waste.ideal.es/sealth.htm

- $\quad$ http://es.wikipedia.org/wiki/Wu_Xing

- http://www.saberoculto.es/HorCHINO4.htm

- Es.wikipedia.org/wiki/Heráclito

- https://es.wikipedia.org/wiki/Pante\%C3\%ADsmo

- http://es.wikipedia.org/wiki/Her\%C3\%A1clito

- http://www.johnvalentino.com/Teaching/Art390/Projects/390Proj3/ JosephBeuys.html

- http://www.kaleidoscopio.com.ar/fs_files/user_img/Arte/Relectura\%20de\% 20Beuys\%20a\%20partir\%20de\%20los\%20c\%C3\%B3digos\%20Barthesianos.pdf

- http://discursosen-transito.blogspot.com.es/2010/08/5a-sesion.htm

- elena.vozmediano.info/giuseppe-penone/

- http://mediation.centrepompidou.fr/education/ressources/ ENS-penone/penone.htm

- http://conlenostreidee.altervista.org/giuseppe-pennone/

- http://www.huffingtonpost.com/2012/09/17/potato-art-giuseppepenone_n_1889816.html

- http://www.facartes.unal.edu.co/catedra_creacion/craneo.pdf

- http://mediation.centrepompidou.fr/education/ressources/ENSpenone/penone.html

- http://the-inner-art.blogspot.com.es/2013/02/la-naturaleza-en-el-arte-degiuseppe.html

- www.waste.ideal.es/seath.htm

- http://artsplastiquesmaupassant.blogspot.com.es/2010/07/giuseppe-penone-etlarbre-des-voyelles.html

- www.museoreinasofia.es/exposiciones/wolfgang-laib-sin-principio-sin-fin

- http://www.elmundo.es/elmundo/2007/04/17/cultura/1176819871.html

- https://lamemoriadelasolas.wordpress.com/2007/06/17/piedra-de-leche/

- http://www.alenasarakapud.com/tags/wolfgang-laib

- http://aragon.lehoulme.free.fr/spip.php?article215

- http://www.art21.org/images/wolfgang-laib/the-rice-meals-1998?slideshow=1

- http://www.sculpture.org/documents/scmag01/may01/laib/laib.sh

- http://www.artinamericamagazine.com/news-features/interviews/wolfgang-laibmoma/

- http://www.architecturaldigest.com/blogs/daily/2013/01/wolfgang-laib-pollenfrom-hazelnut-moma

- http://www.smithsonianmag.com/science-nature/the-otherworldly-calm-ofwolfgang-laibs-glowing-beeswax-room-9127160/?no-ist

- http://www.conectadosporeluniverso.com/despertar-de-conciencia/de-gusano-amariposa/

- http://es.dreamstime.com/foto-de-archivo-libre-de-regal\%C3\%ADas-mariposahuerta-swallowtail-macho-del-ciclo-vital-image24511555 
- http://www.bibliotecasvirtuales.com7biblioteca/Articulos/ AbrahamBastidaAguilar/mariposa monarca.asp

- http://redescolar.ilce.edu.mx/redescolar/actpermanentes/historia/ histdeltiempo/mundo/prehis/t_evolu.htm

- http://www.adapse.com/texto/poemas.html

- http://betweenoldcontemporaryart.files.wordpress.com/2014/07/fig_-5-sentieroe-muro-penone-firenze.jpg

- http://www.sea-entomologia.org/PDF/BOLETIN_12/B12-013-031.pdf

- http://www.museodebogota.gov.co/descargas/publicaciones/pdf/ Glosario_funerario. Pdf

- https://es.wikipedia.org/wiki/Pante\%C3\%ADsmo\#Spinoza

- http://www.ciudadseva.com/textos/poesia/esp/machado_a/ anoche_cuando_dormia. htm

- http://www.poemas-del-alma.com/pablo-neruda-esta-campana-rota.htm

- http://www.sculpture.org/documents/scmag01/may01/laib/laib.shtml

- http://salonkritik.net/06-07/2007/04/

- https://es.wikipedia.org/wiki/Pante\%C3\%ADsmo

- http://fress.co/20-dibujos-que-muestran-las-diferencias-entre-oriente-china-yoccidente-alemania/

- www. Eduinnova.es/ene2010/Arte_oriental.pdf

- http://escultura2hh.blogspot.com.es/ 

8. Índice de ilustraciones 


\section{llustración 1.}

El taijitu, la forma más conocida de representar el concepto del yin y el yang (yīnyáng). https://es.wikipedia.org/wiki/Yin_y_yang

(06/09/2015 a las $12: 18 \mathrm{~h})$

\section{Ilustración 2.}

Cuatro imágenes iniciales que al añadirles un trazo más, se convierten en los ocho trigramas. WILHEM, Richard. "I Ching. El Libro de las Mutaciones". Editorial Sudamericana. Buenos Aires, 2001. Pág. 407.

\section{Ilustración 3.}

Los cinco elementos.

http://www.saberoculto.es/HorCHINO4.htm

(03/06/2015 a las 11h)

\section{Ilustración 4.}

Lao-Tse.

https://es.wikipedia.org/wiki/Lao-Tse

$(09 / 07 / 2015$ a las $12: 50 h)$

\section{Ilustración 5.}

Heráclito Ilorando; por Hendrick Ter Brugghen (1628)

https://es.wikipedia.org/wiki/Her\%C3\%A1clito

(04/05/2015 a las $16: 44 \mathrm{~h})$

\section{Ilustración 6.}

Retrato de Baruch de Spinoza cerca de 1665. http://es.wikipedia.org/wiki/Baruch_Spinoza (04/05/2015 a las $16: 45 \mathrm{~h})$

\section{Ilustración 7.}

Casa Tassel (Escaleras). Victor Horta.

http://historia3modernismo.blogspot.com.es/2011/01/art-nouveau-victor-horta.html (23/08/2015 a las 20:05h)

\section{Ilustración 8.}

Pintura de Ren Xun (1835-1893).

http://www.chinafinearts.com/china art_02.htm

$(23 / 08 / 2015$ a las $11: 12 \mathrm{~h})$

\section{Ilustración 9.}

Guo Xi. Principios de la primavera, firmado y fechado en 1072. Colgante pergamino, tinta y color en 158.3×108.1 seda. Museo Nacional del Palacio, Taipei.

https://en.wikipedia.org/wiki/Guo_Xi

$(23 / 08 / 2015$ a las $12: 15 \mathrm{~h})$

\section{Ilustraciones de la 10 a la 15.}

Diferencias entre cultura oriental y occidental http://fress.co/20-dibujos-que-muestran-las-diferencias-entre-oriente-china-y-occidentealemania/

$(21 / 08 / 2015$ a las $12: 11 \mathrm{~h})$

\section{Ilustraciones 16 y 17.}

Las cribadoras, 1859

El sueño, detalle, 1866.

https://es.wikipedia.org/wiki/Gustave_Courbet

$(27 / 08 / 2015$ a las $11: 24 \mathrm{~h})$ 


\section{Ilustración 18.}

Joseph Beuys I Like America and America Likes Me, 1974. (Coyote)

http://www.johnvalentino.com/Teaching/Art390/Projects/390Proj3/JosephBeuys.html

$(05 / 07 / 2015$ a las $10: 36 h)$

\section{Ilustraciones 19 y 20.}

Me gusta América. Le gusto a América - 1974.

http://www.kaleidoscopio.com.ar/fs_files/user_img/Arte/Relectura\%20de\%20Beuys\%20a\%20pa rtir\%20de\%20los\%20c\%C3\%B3digos\%20Barthesianos.pdf

(24/05/2015 a las $9: 39 h)$

\section{Ilustraciones 21 y 22.}

Cómo explicar cuadros a una liebre muerta - 1965

http://www.kaleidoscopio.com.ar/fs_files/user_img/Arte/Relectura\%20de\%20Beuys\%20a\%20pa rtir\%20de\%20los\%20c\%C3\%B3digos\%20Barthesianos.pdf

(24/05/2015 a las 9:41h)

\section{Ilustraciones 23 y 24.}

Bomba de miel en el lugar de trabajo - 1977.

http://www.kaleidoscopio.com.ar/fs_files/user_img/Arte/Relectura\%20de\%20Beuys\%20a\%20pa rtir\%20de\%20los\%20c\%C3\%B3digos\%20Barthesianos.pdf

(24/05/2015 a las $9: 44 h)$

\section{Ilustración 25}

Joseph Beuys Bomba de miel en el lugar de trabajo, 1977.

http://discursosen-transito.blogspot.com.es/2010/08/5a-sesion.html

$(28 / 05 / 2015$ a las $08: 12 h)$

\section{Ilustración 26}

[Alpes Maritimos. Continuará creciendo excepto en aquel punto], 1968

Vista tomada durante la realización de la obra.

http://mediation.centrepompidou.fr/education/ressources/ENS-penone/penone.html

$(03 / 06 / 2015$ a las $10: 25 h)$

\section{Ilustración 27.}

"Patatas" ("Patates") realizada en 1977.

http://conlenostreidee.altervista.org/giuseppe-pennone/

(03/06/2015 a las $10: 37 \mathrm{~h})$

\section{Ilustraciones 28 y 29.}

Patatas con forma de ojos, oidos, nariz y boca. Giuseppe Penone. Basler Kunstmuseum http://www.huffingtonpost.com/2012/09/17/potato-art-giuseppe-penone_n_1889816.html $(08 / 06 / 2015$ a las $10 \mathrm{~h})$

\section{Ilustración 30}

Proyecto para escultura al aire libre.

VV.AA. "Giuseppe Penone, 1968-1998": 22 Xaneiro-4 abril 1999. Centro Gallego de Arte

Contemporáneo. Santiago de Compostela: Xunta de Galicia, D, L.1999. Pág. 13.

\section{Ilustración 31.}

Être fleuve 1 [Essere fiume 1], 1981. Pierre naturelle et pierre taillée. (Ser río), 1981. Piedra natural y piedra tallada. Ph. Salvatore Mazza, 1981

http://mediation.centrepompidou.fr/education/ressources/ENS-penone/penone.html (03/06/2015 a las $10: 27 \mathrm{~h})$

\section{Ilustraciones 32 y 33 .}

Penone trabajando el cedro de Versalles,2000

El cedro de Versalles, 2000-2003

http://the-inner-art.blogspot.com.es/2013/02/la-naturaleza-en-el-arte-de-giuseppe.html

(09/06/2015 a las 10:30h) 


\section{Ilustraciones 34 y 35.}

Soplo de hojas.

Hojas de boj. 1979.

http://artsplastiquesmaupassant.blogspot.com.es/2010/07/giuseppe-penone-et-larbre-desvoyelles.html (08/06/2015 a las 9:26h)

\section{Ilustración 36.}

Wolfgang Laib posa junto a su obra, 'Nowhere-Everywhere' (Foto: EFE). http://www.elmundo.es/elmundo/2007/04/17/cultura/1176819871.html $(06 / 07 / 2015$ a las $18: 20 \mathrm{~h})$

\section{Ilustración 37.}

Proceso "Milkstone" ("Piedra de leche"). https://lamemoriadelasolas.wordpress.com/2007/06/17/piedra-de-leche/ $(14 / 06 / 2015$ a las 09:18h)

\section{Ilustración 38.}

Milkstone, every day ritual (Milkstone, ritual diario) http://www.alenasarakapud.com/tags/wolfgang-laib $(06 / 07 / 2015$ a las $18: 48 \mathrm{~h})$

\section{Ilustración 39.}

"Milkstone". http://aragon.lehoulme.free.fr/spip.php?article215

$(14 / 06 / 2015$ a las $09: 20 \mathrm{~h})$

\section{Ilustraciones 40 y 41.}

Detalle de la obra de Wolfgang Laib "Rice Meals".

Su obra "Rice Meals" ("Platos de arroz")

http://www.art21.org/images/wolfgang-laib/the-rice-meals-1998?slideshow=1

$(16 / 06 / 2015$ a las $8: 41 \mathrm{~h})$

\section{Ilustración 42.}

Recolección de polen por Wolfgang Laib.

http://www.sculpture.org/documents/scmag01/may01/laib/laib.shtml

$(17 / 06 / 2015$ a las $10: 37 \mathrm{~h})$

\section{Ilustración 43.}

Materiales de trabajo. (Ph: Jason Mandella)

http://www.artinamericamagazine.com/news-features/interviews/wolfgang-laib-moma/ $(16 / 06 / 2015$ a las $8: 45 h)$

\section{Ilustraciones 44 y 45.}

Wolfgang Laib instalando su trabajo "Pollen from Hazelnut" en el MOMA. 2013

Su obra "Pollen from Hazelnut" en el MOMA. 2013

http://www.architecturaldigest.com/blogs/daily/2013/01/wolfgang-laib-pollen-from-hazelnutmoma

(16/06/2015 a las 9:15h)

\section{Ilustraciones 46 y 47.}

Wolfgang Laib instalando la "Habitación de cera"

Laib utiliza una plancha caliente, cuchillos y espátulas para trabajar la cera de abejas. Fotos por Rhiannon Newman.

http://www.smithsonianmag.com/science-nature/the-otherworldly-calm-of-wolfgang-laibsglowing-beeswax-room-9127160/?no-ist

(06/07/2015 a las 19:44h)

\section{Ilustración 48.}

Imago recién emergido de Papilio machaon.

http://www.conectadosporeluniverso.com/despertar-de-conciencia/de-gusano-a-mariposa/ $(18 / 06 / 2015$ a las $10: 39 h)$ 


\section{Ilustración 49.}

Las fases del ciclo vital de la mariposa.

http://es.dreamstime.com/foto-de-archivo-libre-de-regal\%C3\%ADas-mariposa-huertaswallowtail-macho-del-ciclo-vital-image24511555

(18/06/2015 a las $11: 50 h)$

\section{Ilustraciones de la 50 a la 53.}

Nacimiento de Papilio machaon.

Oruga de Papilio machaon.

Crisálida de Papilio machaon.

Imago recién emergido de Charaxes Jasius.

Córdoba León, Juan ramón; Sesma Moranas, José Manuel y Martín Toral, Gabino. "Mariposas en libertad“. Ediciones Publimarca. Madrid, 2.006. Págs. 16, 17, 19 y 15.

\section{llustraciones de la 54 a la 56.}

Cera virgen.

Parafina.

Resina de colofonia.

http://escultura2hh.blogspot.com.es/

(21/09/2015 a las 8:32h).

\section{Ilustración 57.}

Modelo en cera con su correspondiente árbol de colada. Pieza de Gil Gijón. Perdiz roja. Curso 2012-2013. Facultad de Bellas Artes de la U.P.V. Foto cedida por la profesora Carmen Marcos Martínez.

\section{Ilustración 58.}

"La fundición artística en la universidad española: La investigación, año 2006". Edita Grupo de Investigación Nuevos Procedimientos Escultóricos. Valencia, 2007. Pág. 122.

\section{Ilustración 59.}

Horno con polea para ser elevado. Su uso está recomendado para sacar las ceras a los moldes de cáscara cerámica.

Corredor Martínez, Juan Antonio. "Técnicas de fundición artística". Ed. Universidad de Granada. Granada, 1.997.Págs. 164, 220 y 244.

\section{Ilustraciones de la 60 a la 64.}

Estado de la pieza después del descere y la cocción

Precalentamiento de las piezas antes de la colada en bronce.

Horno de fundición.

Colada en bronce. Momento del vertido del metal fundido en los moldes de cáscara cerámica.

Vegetal. Año 2.000.

Fotografías de la autora de la tesis.

\section{Ilustración 65.}

"Sentiero". Giuseppe Penone.

http://betweenoldcontemporaryart.files.wordpress.com/2014/07/fig_-5-sentiero-e-muro-penonefirenze.jpg

(30/06/2015 a las 09:37h)

\section{Ilustración 66.}

Noche estrellada-Starry Night-Vincent Van Gogh. Museo de Arte Moderno de Nueva York. 1890. $73,7 \times 92,1 \mathrm{~cm}$. Óleo sobre lienzo http://museodelarte.blogspot.com.es/2012/02/noche-estrellada-vincent-van-gogh.html $(28 / 08 / 2015$ a las $10: 49 \mathrm{~h})$ 


\section{Ilustraciones 67 y 68. (Anexo)}

Cuatro imágenes iniciales que al añadirles un trazo más, se convierten en los ocho tigramas. Los ocho signos básicos con sus atributos, función de sus imágenes y posición en el contexto familiar.

WILHEM, Richard. "I Ching. El libro de las Mutaciones". Editorial Sudamericana. Buenos Aires, 2001. Págs.407 y 445.

Ilustraciones de la 69 a la 88. (Anexo)

Diferencias entre cultura oriental y occidental http://fress.co/20-dibujos-que-muestran-las-diferencias-entre-oriente-china-y-occidentealemania/

(21/08/2015 a las $18.45 h)$ 
Anexo 


\section{Carta del jefe indio Noah Sealth, 1854.}

¿Cómo se puede comprar o vender el firmamento, ni aun el calor de la tierra?

Dicha idea nos es desconocida.

Si no somos dueños de la frescura del aire ni del fulgor de las aguas, ¿cómo podrán ustedes comprarlos?

Cada parcela de esta tierra es sagrada para mi pueblo. Cada brillante mata de pino, cada grano de arena en las playas, cada gota de rocío en los bosques, cada altozano y hasta el sonido de cada insecto, es sagrada a la memoria y el pasado de mi pueblo. La savia que circula por las venas de los árboles lleva consigo las memorias de los pieles rojas.

Los muertos del hombre blanco olvidan su país de origen cuando emprenden sus paseos entre las estrellas, en cambio nuestros muertos nunca pueden olvidar esta bondadosa tierra puesto que es la madre de los pieles rojas. Somos parte de la tierra y asimismo ella es parte de nosotros. Las flores perfumadas son nuestras hermanas; el venado, el caballo, la gran águila; estos son nuestros hermanos. Las escarpadas peñas, los húmedos prados, el calor del cuerpo del caballo y el hombre, todos pertenecemos a la misma familia.

Por todo ello, cuando el Gran Jefe de Washington nos envía el mensaje de que quiere comprar nuestras tierras, nos está pidiendo demasiado. También el Gran Jefe nos dice que nos reserva un lugar en el que podemos vivir confortablemente entre nosotros. El se convertirá en nuestro padre, y nosotros en sus hijos. Por ello consideramos su oferta de comprar nuestras tierras. Ello no es fácil, ya que esta tierra es sagrada para nosotros. El agua cristalina que corre por los ríos y arroyuelos no es solamente agua, sino que también representa la sangre de nuestros antepasados. Si les vendemos tierras, deben recordar que es sagrada, y a la vez deben enseñar a sus hijos que es sagrada y que cada reflejo fantasmagórico, en las claras aguas de los lagos cuenta los sucesos y memorias de las vidas de nuestras gentes. El murmullo del agua es la voz del padre de mi padre.

Los ríos son nuestros hermanos y sacian nuestra sed; son portadores de nuestras canoas y alimentan a nuestros hijos. Si les vendemos nuestras tierras, ustedes deben recordar y enseñarles a sus hijos que los ríos son nuestros hermanos y también los suyos, y por lo tanto, deben tratarlos con la misma dulzura con que se trata a su hermano.

Sabemos que el hombre blanco no comprende nuestro modo de vida. El no sabe distinguir entre un pedazo de tierra y otro, ya que es un extraño que llega de noche $y$ toma de la tierra lo que necesita. La tierra no es su hermana, sino su enemiga y una vez 
conquistada sigue su camino, dejando atrás la tumba de sus padres sin importarle. Le secuestra la tierra de sus hijos. Tampoco le importa. Tanto la tumba de sus padres, como el patrimonio de sus hijos son olvidados. Trata a su madre, la Tierra, y a su hermano, el firmamento, como objetos que se compran, se explotan y se venden como ovejas o cuentas de colores.

Su apetito devorará la tierra dejando atrás solo su desierto. No sé, pero nuestro modo de vida es diferente al de ustedes. La sola vista de sus ciudades apena la vista del piel roja. Pero quizás sea porque el piel roja es un salvaje y no comprende nada.

No existe un lugar tranquilo en las ciudades del hombre blanco, ni hay sitio donde escuchar cómo se abren las hojas de los árboles en primavera o como aletean los insectos. Pero quizá también esto debe ser porque soy un salvaje que no comprende nada. El ruido parece insultar nuestros oídos. Y después de todo, ¿para qué sirve la vida si el hombre no puede escuchar el grito solitario del chotacabras ni las discusiones nocturnas de las ranas al borde de un estanque? Soy un piel roja y nada entiendo. Nosotros preferimos el suave susurro del viento sobre la superficie de un estanque, así como el olor de ese mismo viento purificado por la lluvia del mediodía o perfumado con aromas de pinos. El aire tiene un valor inestimable para el piel roja, ya que todos los seres comparten un mismo aliento-la bestia, el árbol, el hombre, todos respiramos el mismo aire. El hombre blanco no parece consciente del aire que respira; como un moribundo que agoniza muchos días es insensible al hedor. Pero si les vendemos nuestras tierras deben recordar que el aire no es inestimable, que el aire comparte su espíritu con la vida que sostiene. El viento que dio a nuestros abuelos el primer soplo de vida, también recibe sus últimos suspiros. Y si les vendemos nuestras tierras, ustedes deben conservarlas como cosa aparte y sagrada, como un lugar donde hasta el hombre blanco puede saborear el viento perfumado por las flores de las praderas. Por ello consideramos su oferta de comprar nuestras tierras. Si decidimos aceptarla, yo pondré una condición: el hombre blanco debe tratar a los animales de esta tierra como sus hermanos.

Soy un salvaje y no comprendo otro modo de vida. He visto a miles de búfalos pudriéndose en las praderas, muertos a tiros por el hombre blanco desde un tren en marcha. Soy un salvaje y no comprendo como una máquina humeante puede importar más que el búfalo al que nosotros matamos sólo para sobrevivir.

¿Qué sería del hombre sin los animales? Si todos fueran exterminados, el hombre también moriría de una gran soledad espiritual; porque lo que le sucede a los animales también le sucederá al hombre. Todo va enlazado.

Deben enseñarles a sus hijos que el suelo que pisan son las cenizas de nuestros abuelos. Inculquen a sus hijos que la tierra esta enriquecida con las vidas de nuestros semejantes a fin de que sepan respetarla. 
Enseñen a sus hijos que nosotros hemos enseñado a los nuestros que la tierra es nuestra madre. Todo lo que le ocurra a la tierra le ocurriría a los hijos de la tierra. Si los hombres escupen en el suelo, se escupen a si mismos. Esto sabemos: la tierra no pertenece al hombre; el hombre pertenece a la tierra; Esto sabemos. Todo va enlazado, como la sangre que une a una familia. Todo va enlazado.

Todo lo que le ocurra a la tierra, le ocurrirá a los hijos de la tierra. El hombre no tejió la trama de la vida; él es sólo un hilo. Lo que hace con la trama se lo hace así mismo. Ni siquiera el hombre blanco, cuyo Dios pasea y habla con él de amigo a amigo, queda exento del sentido común.

Después de todo, quizás seamos hermanos. Ya veremos, sabemos una cosa que quizá el hombre blanco descubra un día: nuestro Dios es el mismo Dios. Ustedes pueden pensar que ahora que Él les pertenece lo mismo que desean que nuestras tierras les pertenezcan; pero no es así. Él es el dios de los hombres y su compasión se comparte por igual entre el piel roja y el hombre blanco. Esta tierra tiene un valor inestimable para Él y si se daña se provocaría la ira del creador. También los blancos se extinguirían, quizás antes que las demás tribus. Contaminan sus lechos y una noche precederán ahogados en sus propios residuos. Pero ustedes caminarán hacia su destrucción, rodeados gloria, inspirados por la fuerza de Dios que los trajo a esta tierra y que por algún designio especial les dio dominio sobre ella y sobre el piel roja. Ese destino es un misterio para nosotros, pues no entendemos por qué se exterminan los búfalos, se doman los caballos salvajes, se saturan los rincones secretos de los bosques con el aliento de tantos hombres y se atiborra el paisaje de las exuberantes colinas con cables parlantes... ¿Dónde está el matorral? Destruido. ¿Dónde está el águila? Desaparecido. Termina la vida y empieza la supervivencia"178.

${ }^{178}$ Carta del jefe indio Noah sealth, 1.854 www.waste.ideal.es/sealth.htm $\quad$ (14/12/12 a las 9:30h). 
I Ching. "El Libro de las Mutaciones". (Explicación más ampliada)

Al principio del origen de todas las cosas, no existía la materia, todo era energía y ésta necesitaba de la unión de dos fuerzas fundamentales como son el Cielo y la Tierra, para materializarse. El Cielo correspondería a la parte Yang, lo luminoso, lo masculino, lo condicionante, lo creativo y vendría representado mediante un trazo continuo _ y la Tierra sería la parte Yin, lo oscuro, lo femenino, lo condicionado, lo receptivo y vendría representada por un trazo dividido en dos partes iguales - Con la duplicación de estas dos fuerzas fundamentales surgen cuatro imágenes diferentes:

$=$ el Yang viejo 0 grande $\equiv$ el Yin viejo o grande $=$ el Yang joven o pequeño $=$ el Yin joven o pequeño, que corresponden a las cuatro estaciones del año. Mediante otro añadido de un trazo surgen luego los ocho signos o trigramas:

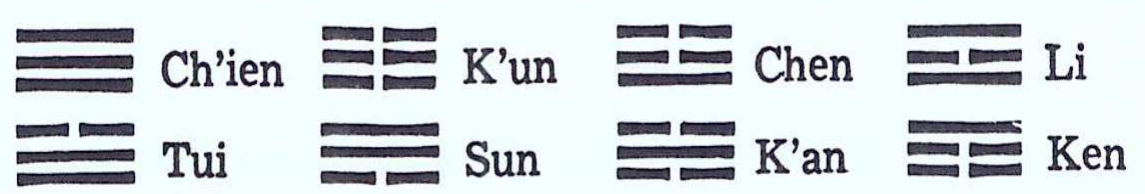

Ilustración 67. Cuatro imágenes iniciales que al añadirles un trazo más, se convierten en los ocho trigramas.

Estos ocho trigramas representan la transformación continua de todos los fenómenos. Los cuales, hacen mención al cielo (Ch'ien), la tierra (K'un), el agua ( $K^{\prime} a n$ ), el fuego (Li), la montaña (Ken), el lago (Tui), el viento (Sun) y el trueno (Chen). De ellos, el cielo y la tierra, serían los progenitores. El viento y el trueno serían los hijos mayores porque el último de los trazos de su trigrama es distinto al resto. El fuego y el agua representarían a los hijos medianos, por encontrarse en el lugar central del trigrama el trazo discordante. Por último, la montaña y el lago representarían a los hijos menores, por encontrarse el trazo discordante en la posición más elevada del trigrama. Como he nombrado anteriormente, estos signos también poseen género, siendo el trueno, el agua y 
la montaña de género masculino y el fuego, el lago y el viento, de género femenino. Esto se debe a que el sexo de cada trigrama viene dado por el trazo discordante que esté presente en cada uno de ellos, es decir, si hay dos trazos continuos y un trazo partido, será éste último el que indique el género del signo, en este caso femenino. Si por el contrario el trigrama se compone de dos líneas partidas y un trazo continuo, este último será el encargado de atribuir el género al signo, en ese caso sería masculino. Por tanto, los ocho signos o trigramas están divididos en dos progenitores, tres hijos y tres hijas.

Estos ocho trigramas hacen mención a los cinco elementos o cinco transformaciones existentes en la cosmología oriental. Estos son, la Tierra, el Agua, el Fuego, la Madera y el Metal. En el I Ching, el elemento Tierra es representado por los trigramas Tierra (K'un) y Montaña (Ken), el elemento Agua es representado por el trigrama Agua ( $\left.K^{\prime} a n\right)$, el elemento madera es representado por los trigramas Viento (Sun) y Trueno (Chen) y el elemento Metal es representado por los trigramas Cielo (Ch'ien) y Lago (Tui) y el elemento Fuego es a su vez representado por el trigrama Fuego (Li).

Los trigramas también indican dirección. El trigrama Tierra corresponde al Suroeste, el trigrama Montaña corresponde al Noreste, el trigrama Agua corresponde al Norte, el trigrama Viento corresponde al Sureste, el trigrama Trueno corresponde al Este, el trigrama Cielo corresponde al Noroeste, el trigrama Lago corresponde al Oeste y el trigrama Fuego corresponde al Sur.

\begin{tabular}{|ccccccc|c|c|c|}
\hline Elemento & Metal & Metal & Fuego & Madera & Madera & Agua & Tierra & Tierra \\
I Ching & Cielo & Lago & Fuego & Viento & Trueno & Agua & Montaña & Tierra \\
Dirección & Noroeste & Oeste & Sur & Sureste & Este & Norte & Noreste & Suroeste \\
Trigramas & $\equiv$ & $\mathbf{E}$ & $\mathbf{\Xi}$ & $\mathbf{E}$ & $\mathbf{\Xi}$ & $\mathbf{m}$ & $\mathbf{\Xi}$ & $\mathbf{E}^{179}$ \\
\hline
\end{tabular}

${ }^{179}$ http://es.wikipedia.org/wiki/Wu_Xing (21/2/2014 a las $\left.11 \mathrm{~h}\right)$. 
Estos ocho signos se pueden interpretar según sus propiedades, según la función de sus imágenes o según su posición en el orden familiar:

\begin{tabular}{|c|c|c|c|}
\hline Ch'ien, & lo Creativo, & $\begin{array}{l}\text { es fuerte, es } \\
\text { el Cielo, }\end{array}$ & el padre \\
\hline K'un, & lo Receptivo, & $\begin{array}{l}\text { es abnegado, es } \\
\text { la Tierra, }\end{array}$ & la madre \\
\hline Chen, & lo Suscitativo, & $\begin{array}{l}\text { es movimiento, es } \\
\text { el trueno o } \\
\text { la madera, }\end{array}$ & $\begin{array}{l}\text { el hijo } \\
\text { mayor }\end{array}$ \\
\hline K'an, & lo Abismal, & $\begin{array}{l}\text { es peligro, es agua } \\
\text { o nubes, }\end{array}$ & $\begin{array}{l}\text { el hijo } \\
\text { del medio }\end{array}$ \\
\hline Ken, & el Aquietamiento & $\begin{array}{l}\text { es detención, } \\
\text { es la montaña, }\end{array}$ & $\begin{array}{l}\text { el hijo } \\
\text { menor }\end{array}$ \\
\hline Sun, & lo Suave & $\begin{array}{l}\text { es penetración, es } \\
\text { el viento o } \\
\text { la madera, }\end{array}$ & $\begin{array}{l}\text { la hija } \\
\text { mayor }\end{array}$ \\
\hline $\mathrm{Li}$ & lo Adherente, & $\begin{array}{l}\text { es luminoso o } \\
\text { condicionado, es } \\
\text { el sol o el } \\
\text { relámpago, es } \\
\text { el fuego, }\end{array}$ & $\begin{array}{l}\text { la hija } \\
\text { del medio }\end{array}$ \\
\hline Tui, & lo Sereno, & $\begin{array}{l}\text { es alegría, es } \\
\text { el lago }\end{array}$ & $\begin{array}{l}\text { la hija } \\
\text { menor }\end{array}$ \\
\hline
\end{tabular}

Ilustración 68. Los ocho signos básicos con sus atributos, función de sus imágenes y posición contexto familiar

Las imágenes representadas por los ocho signos 0 trigramas corresponden a estados de mutación, de cambio continuo, de transformación constante.

Es la duplicidad de estos ocho trigramas, la que nos lleva hasta los sesenta y cuatro hexagramas existentes en el "I Ching". Cada uno de ellos se representa mediante seis trazos y hace mención a un cambio en la naturaleza. Estos cambios son cíclicos, como sucede con el día y la noche, el transcurrir de las estaciones, la vida y la muerte... y todo ello se basa en la dialéctica entre los opuestos. No puede existir el bien sin el mal, la pobreza sin la riqueza, la salud sin la enfermedad, la vida sin la muerte, la luz sin la oscuridad... Nada hay que sea inalterable al cambio, porque todo está en un constante 
movimiento. No existe el cien por cien, todo conlleva un porcentaje de su opuesto.

Como último componente del I Ching, encontramos los Dictámenes o Sentencias, se podría decir, que su función es atribuir palabras a las imágenes que acompañan cada hexagrama. 


\section{Yang Liu}

La diseñadora nacida en China Yang Liu, que a la edad de 14 años se traslado a vivir a Alemania, es conocedora de ambas culturas y ha decidido crear una obra que refleja las diferencias existentes entre la cultura de oriente y occidente, mediante una serie de 20 dibujos o ilustraciones sencillas, pero muy esclarecedoras. El lado de color azul corresponde a Occidente y el lado de color rojo corresponde a Oriente.

\section{Cómo esperar en el turno}

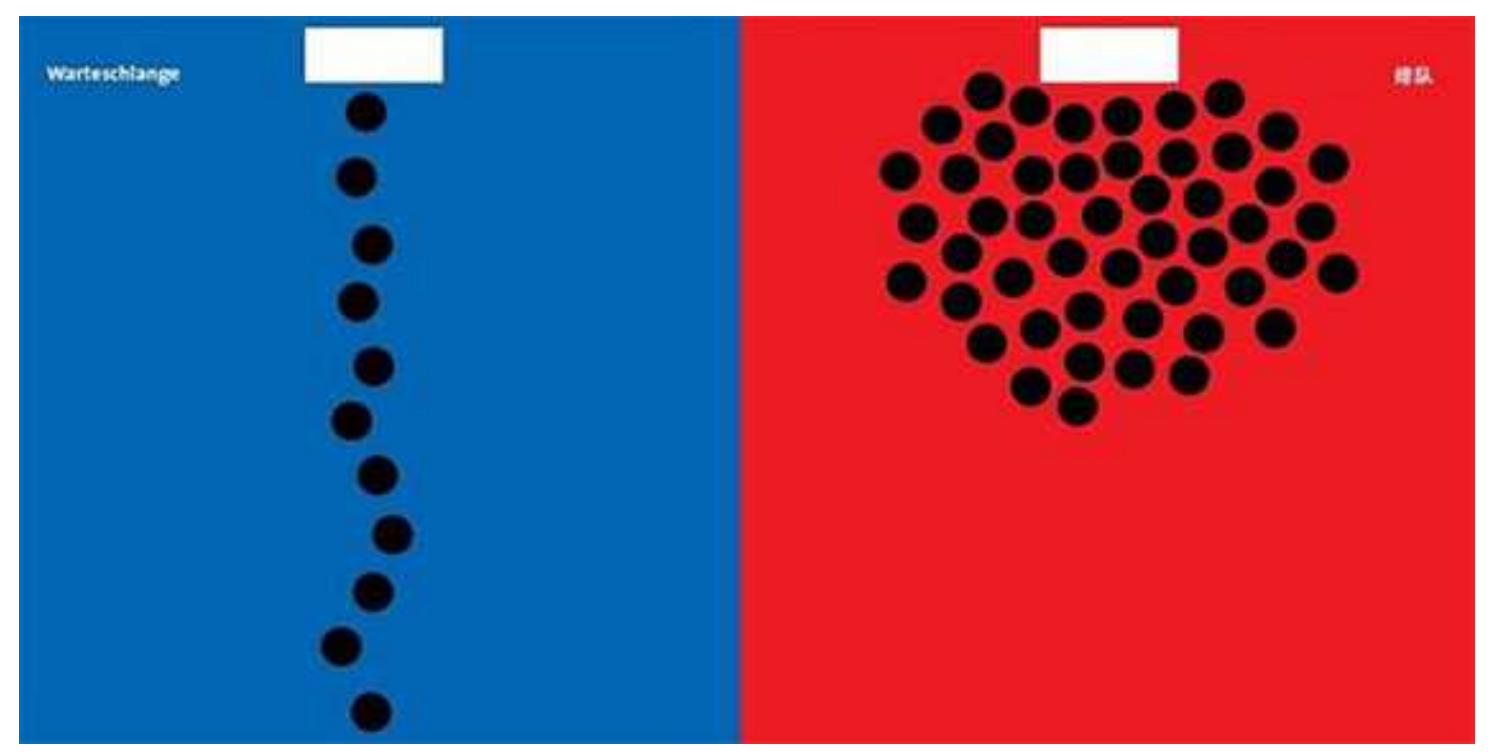

Ilustración 69 


\section{Visión de los animales}

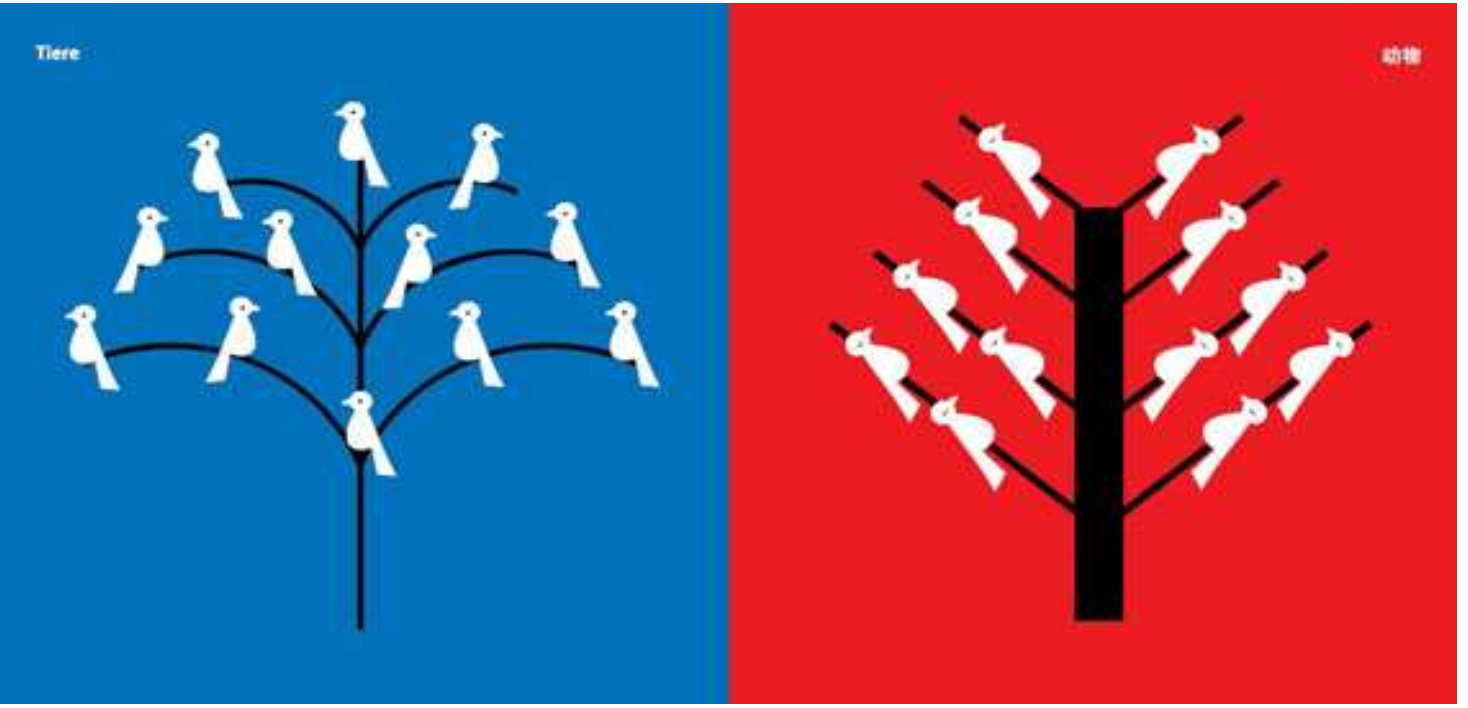

Ilustración 70

Enfoque para resolver un problema

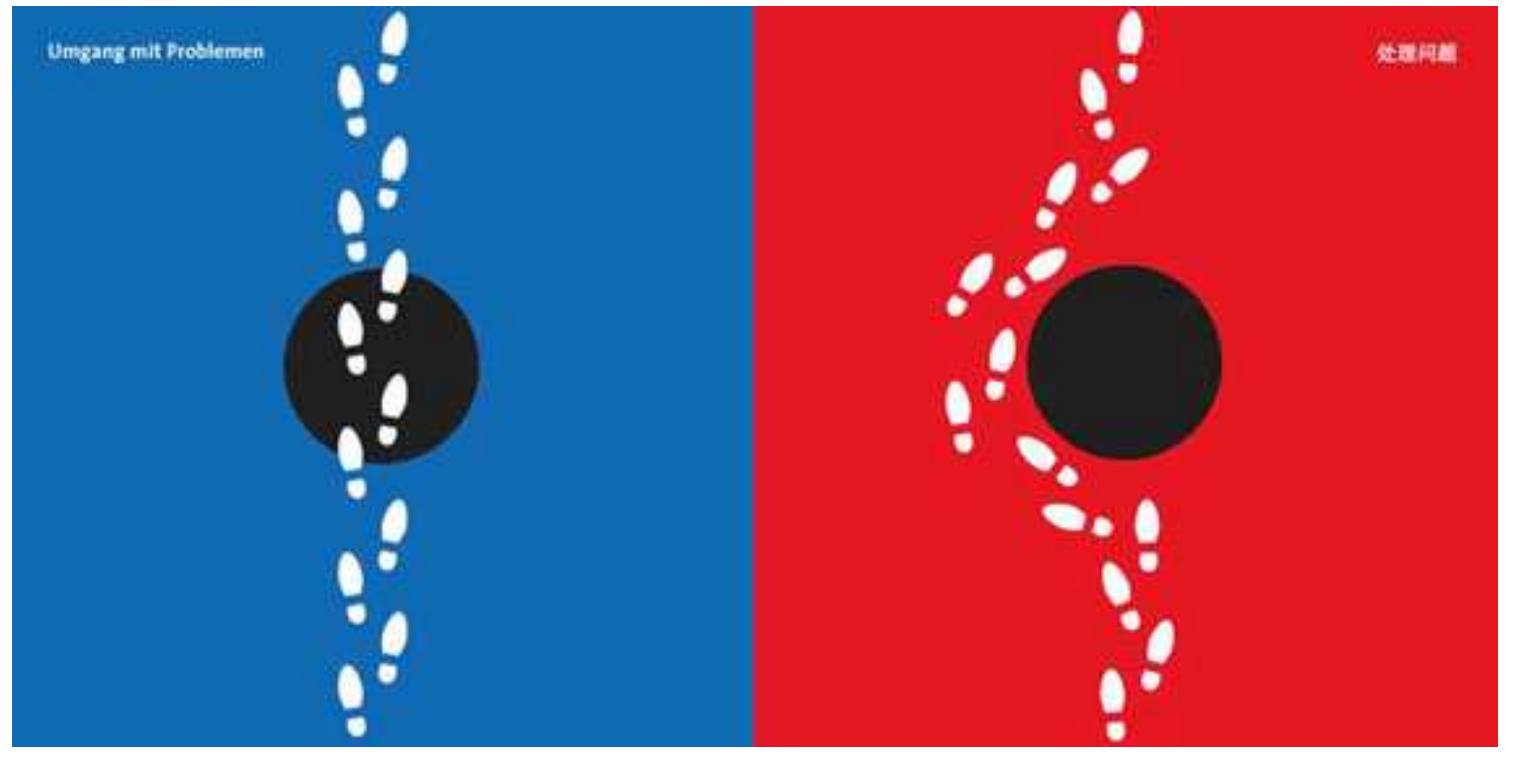

Ilustración 71 


\section{Personas en una fiesta}

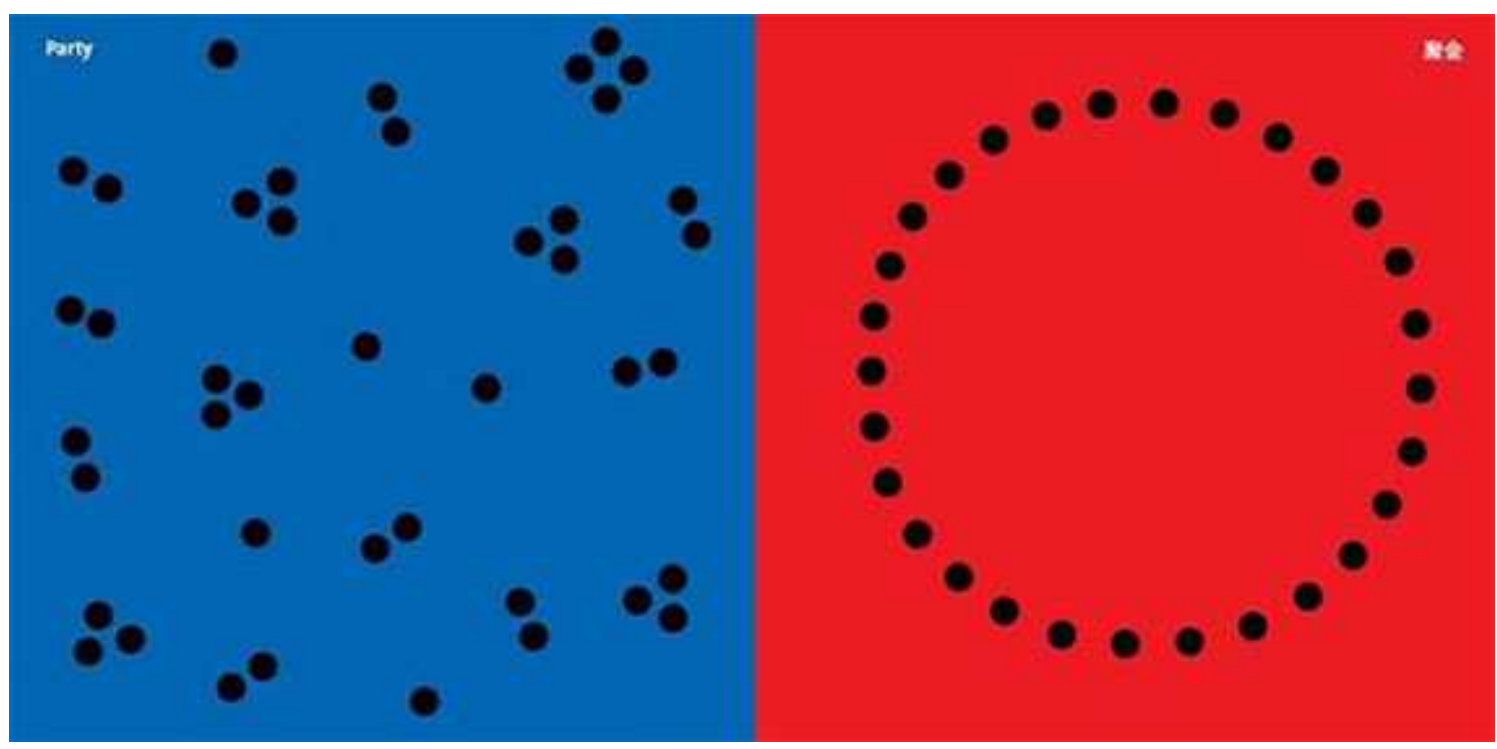

\section{Ilustración 72}

\section{Contactos interpersonales}

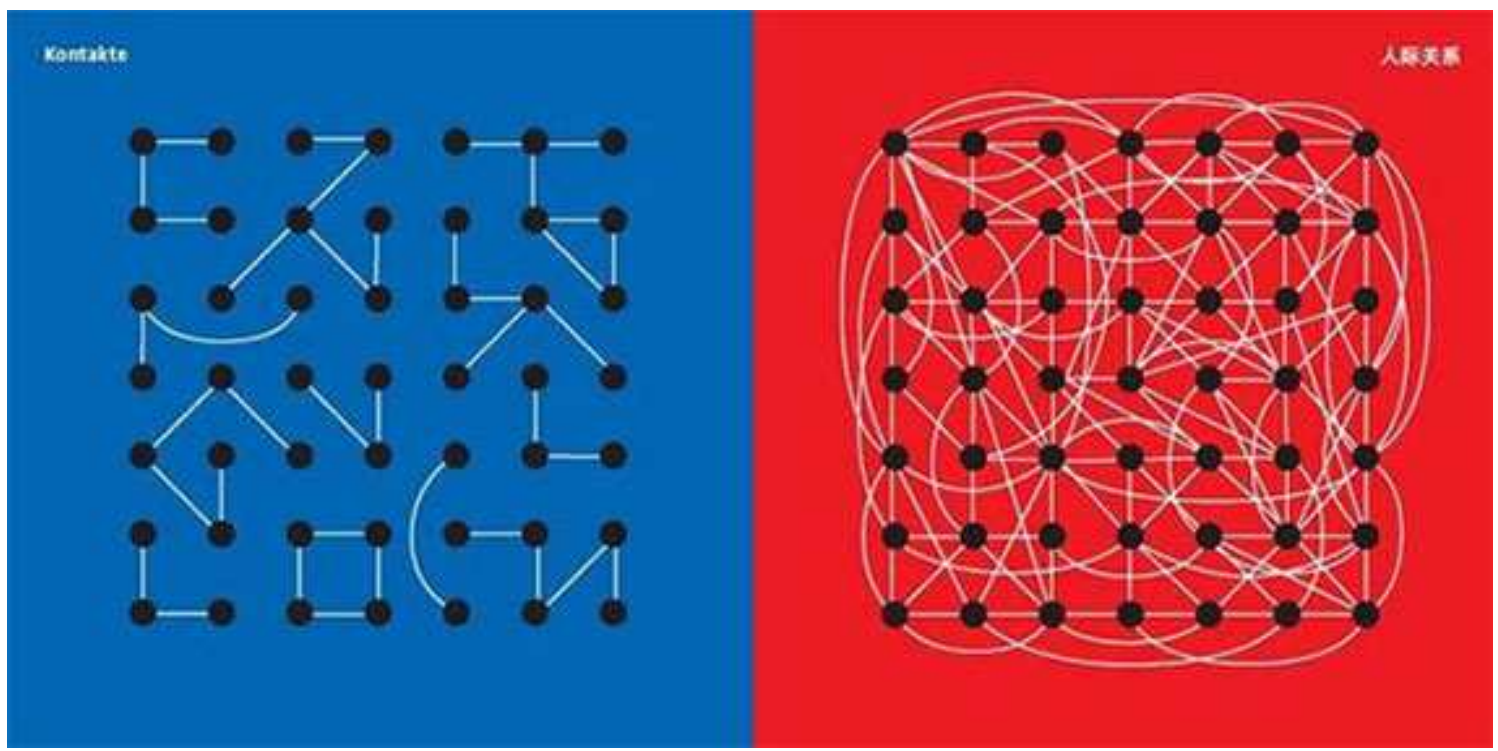

Ilustración 73 


\section{Ruido en un restaurante}

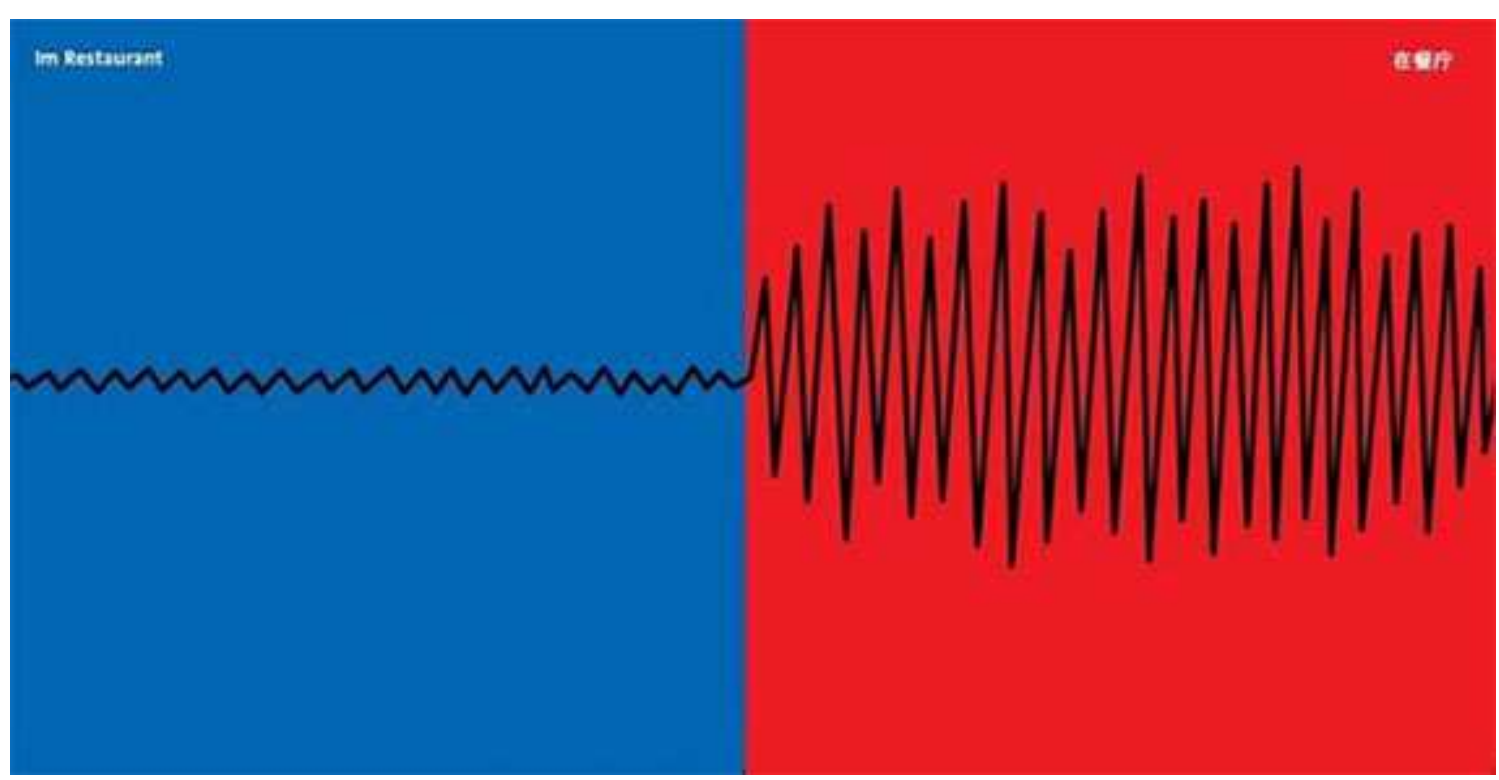

Ilustración 74

\section{Puntualidad}

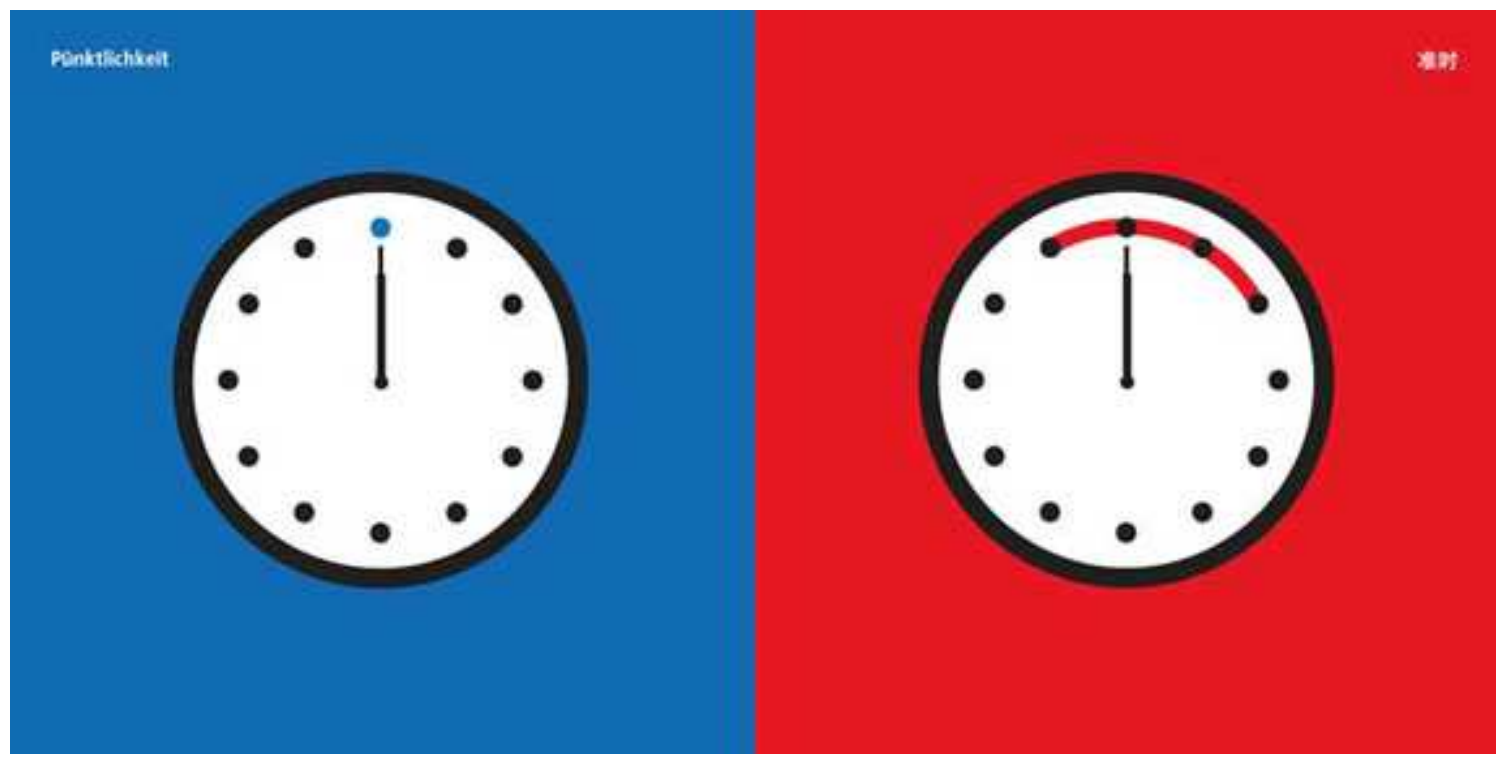

Ilustración 75 


\section{Estilo de vida}

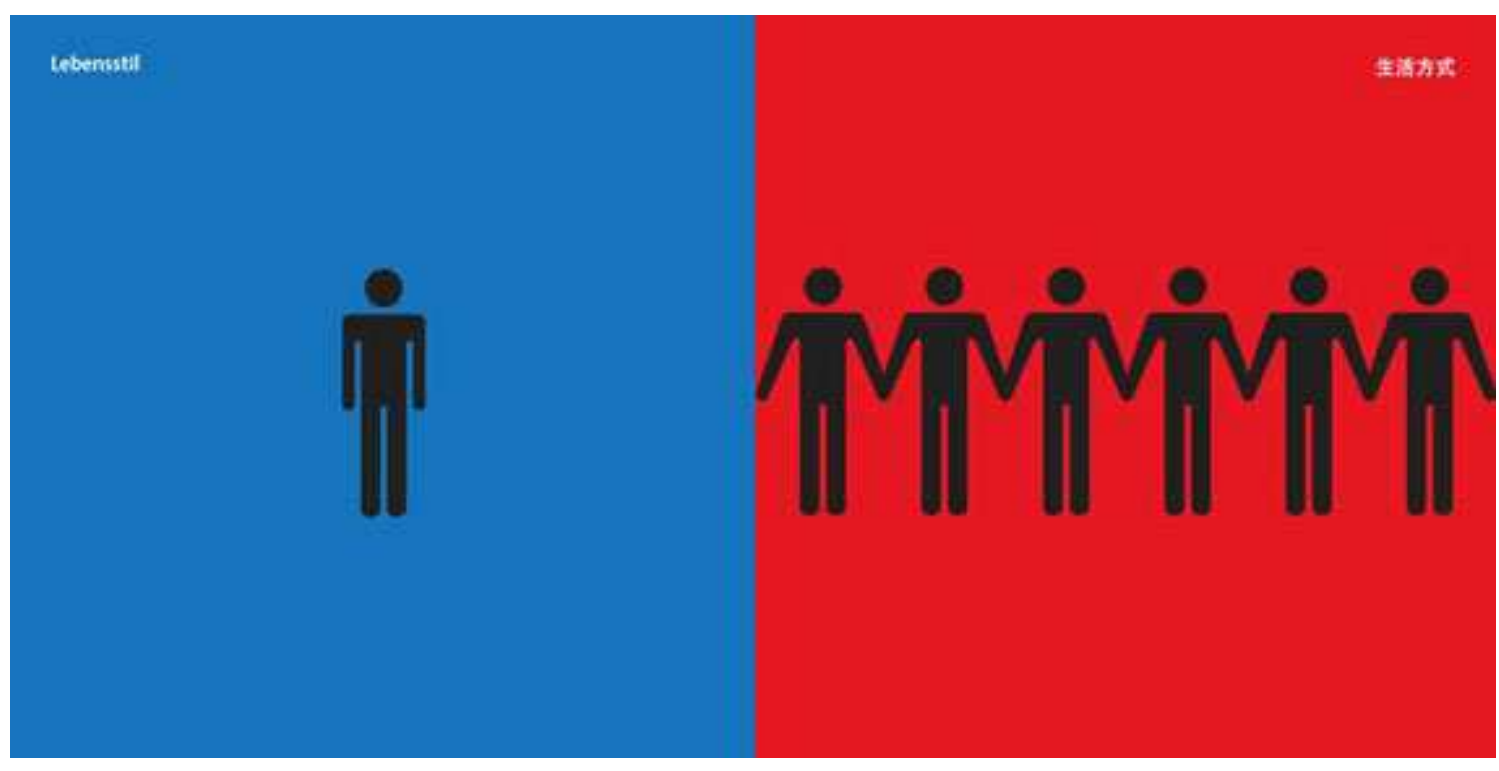

Ilustración 76

Exteriorización de los sentimientos

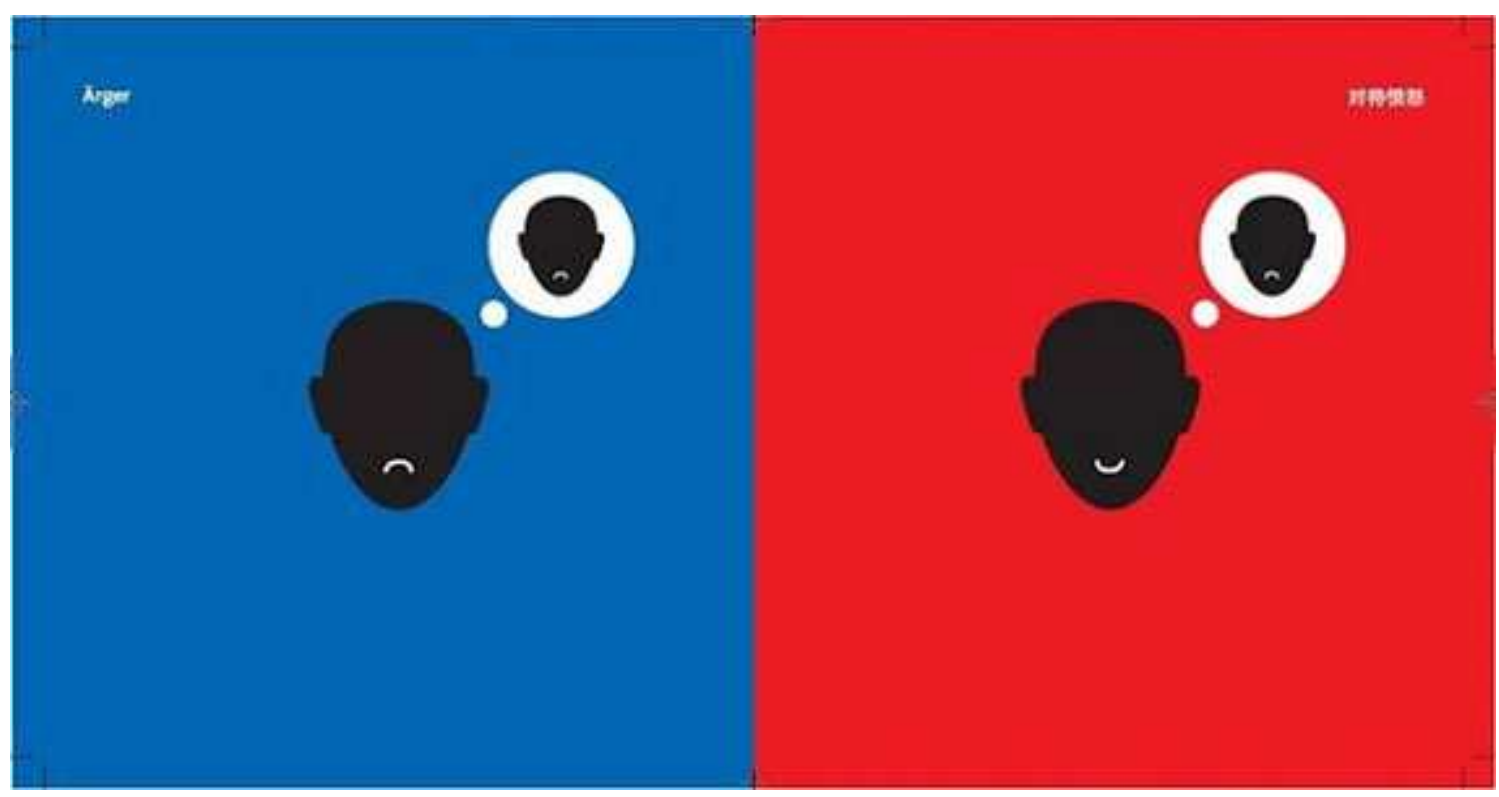

Ilustración 77 


\section{El jefe}

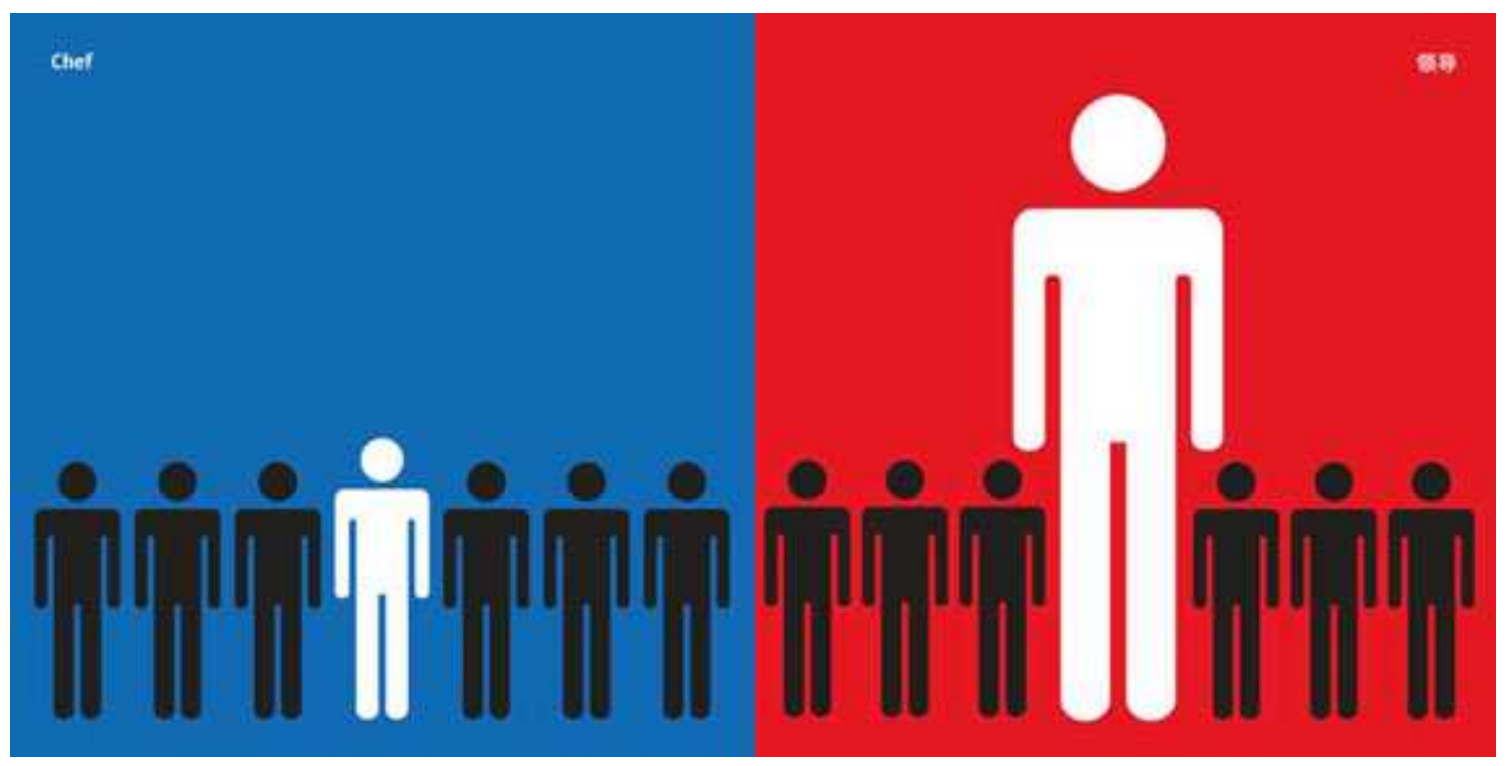

Ilustración 78

Reacción ante algo nuevo

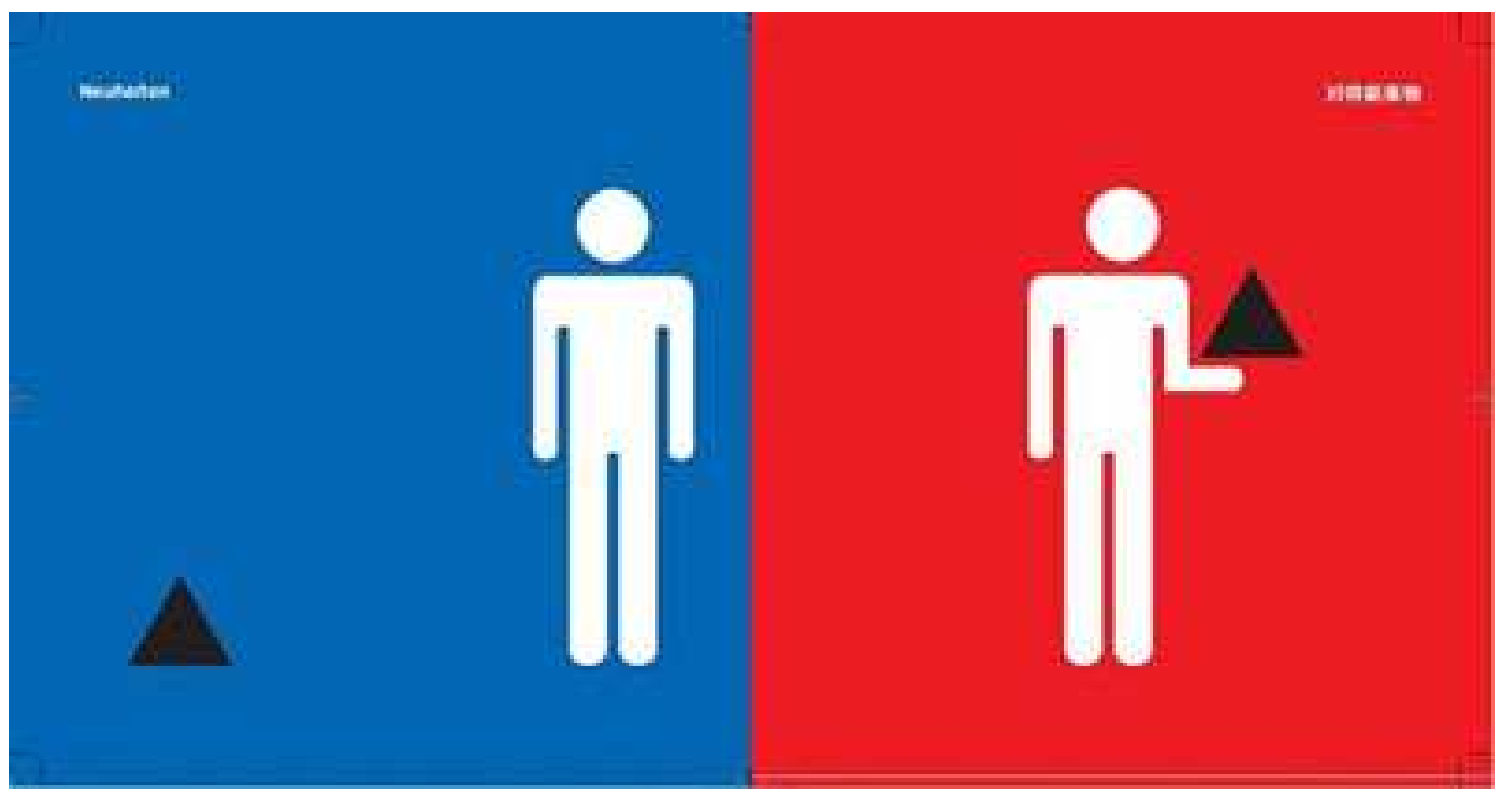

Ilustración 79 


\section{Los viajes}

$$
\text { Belien }
$$
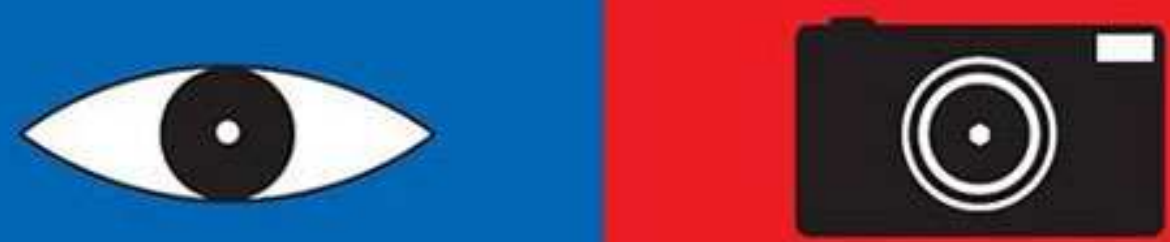

Ilustración 80

Durante la vejez

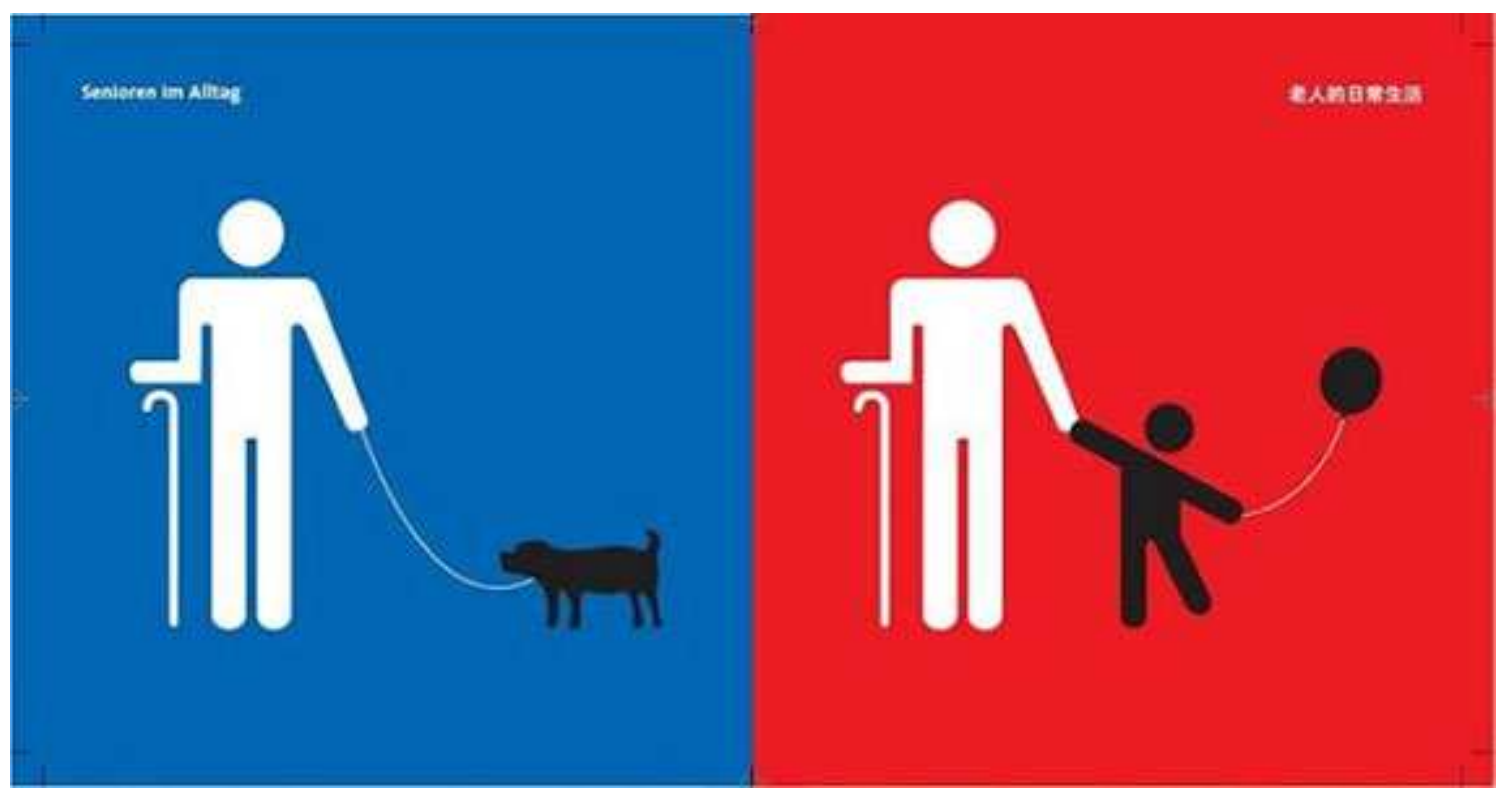

Ilustración 81 
El Ego

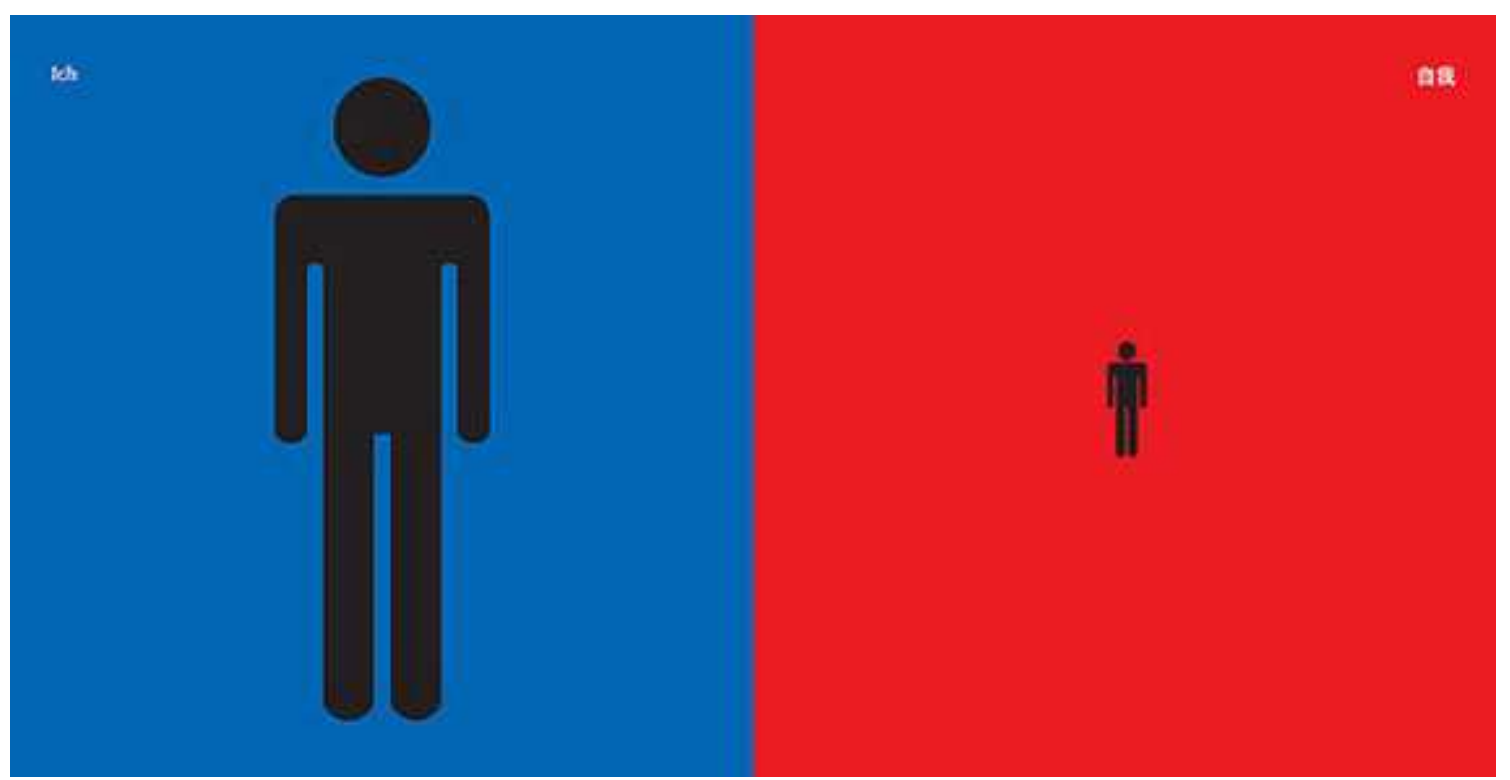

Ilustración 82

Percepción de los alemanes sobre China y de los chinos sobre Alemania

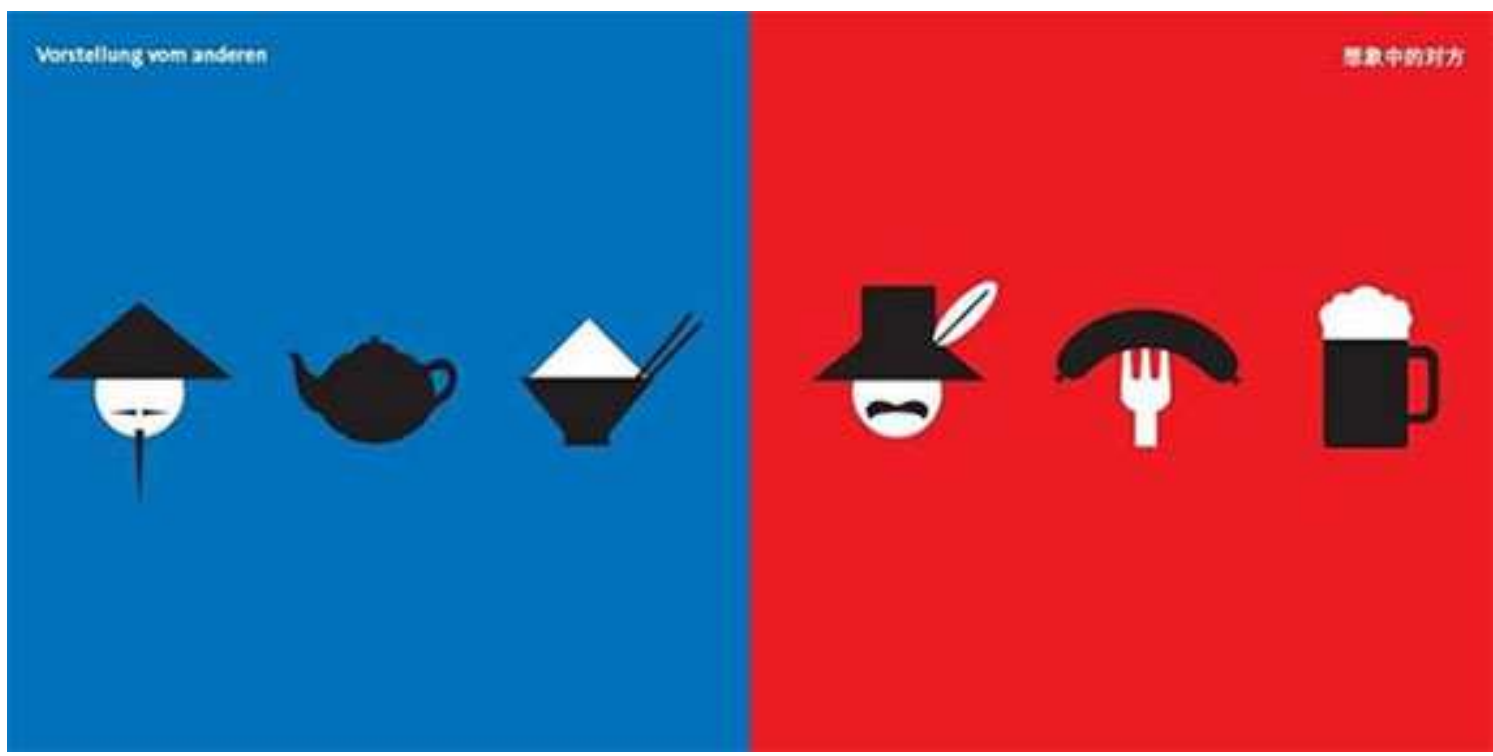

Ilustración 83 


\section{Expresión de las opiniones}
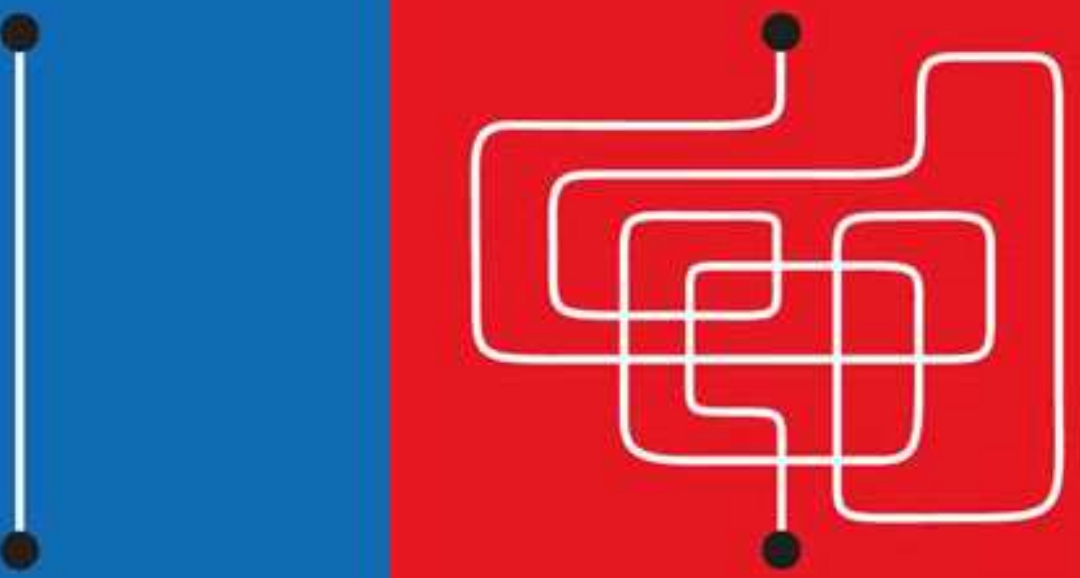

\section{Ilustración 84}

\section{Interacción de la familia con los niños}

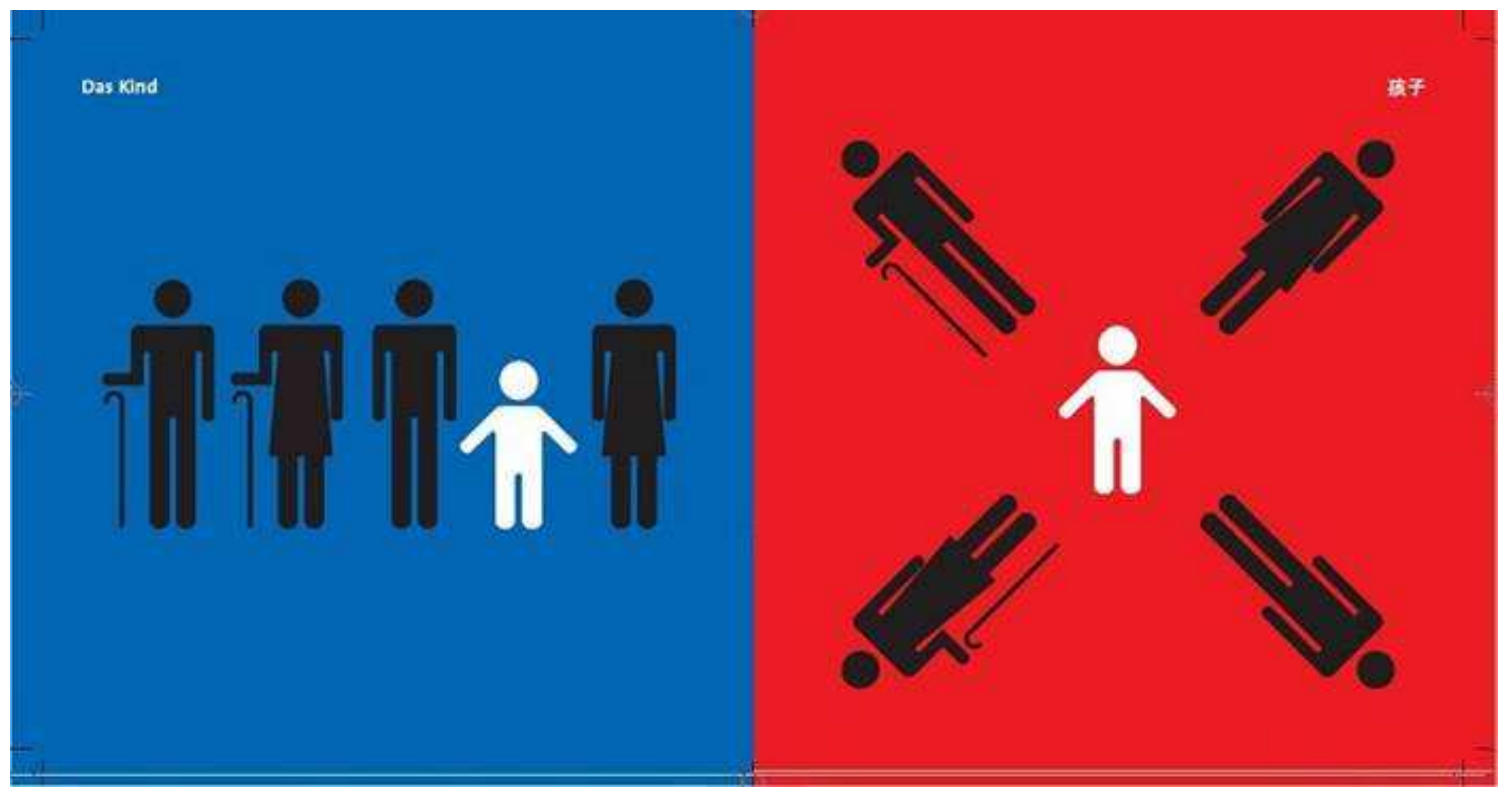

Ilustración 85 
Relación entre el humor y el clima

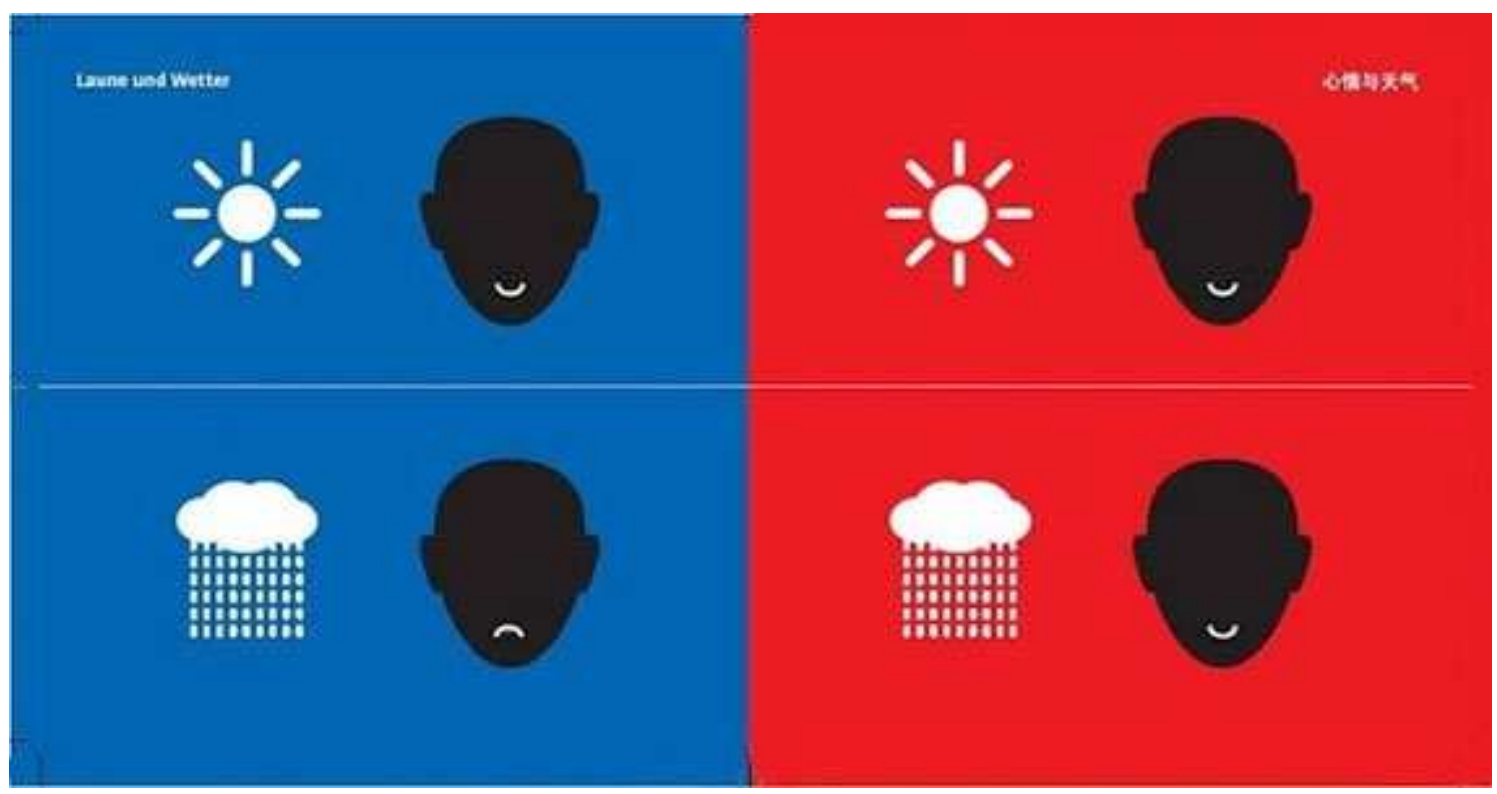

llustración 86

Hora de la ducha

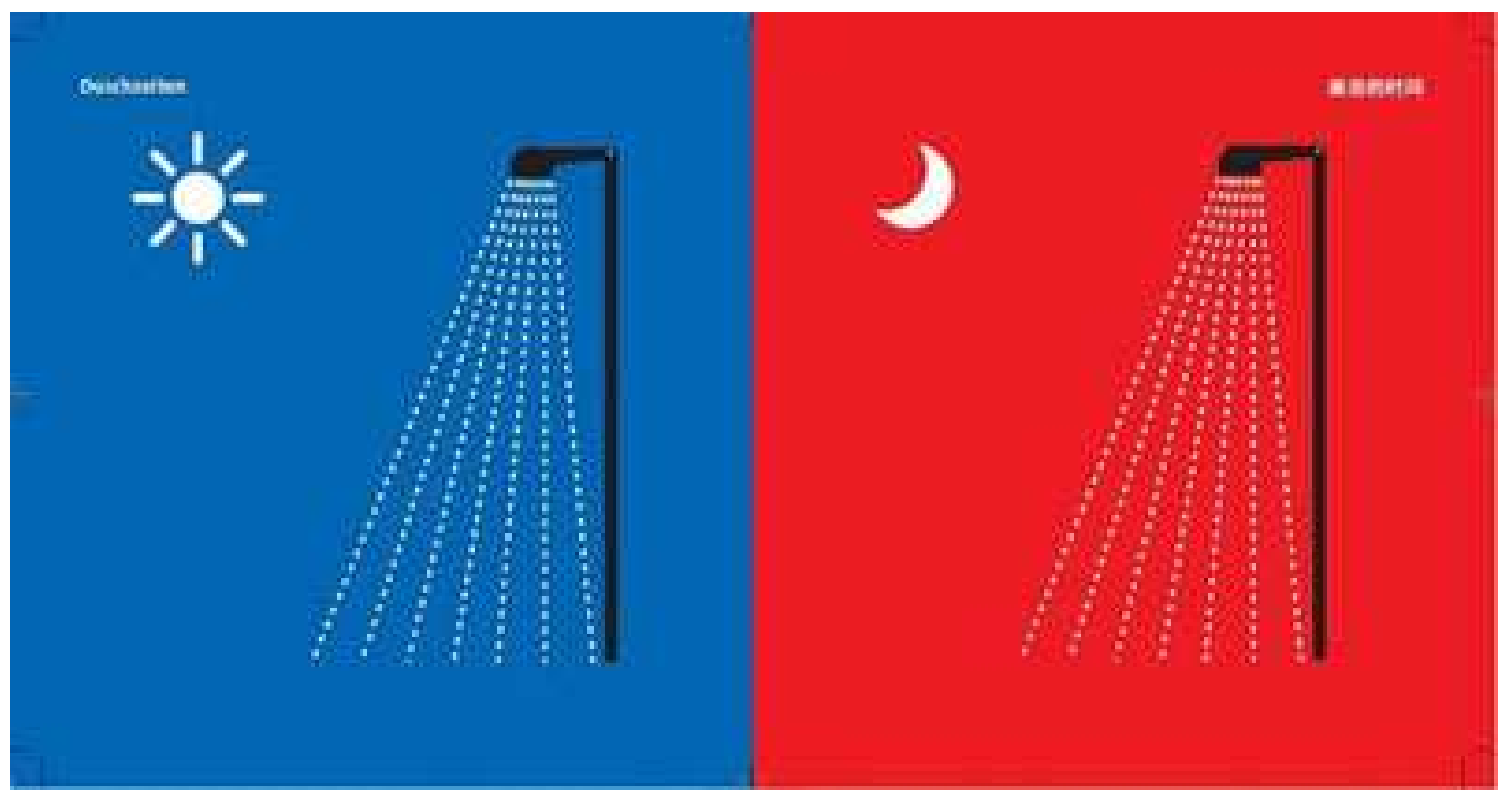

Ilustración 87 
Comidas durante el día (frías o calientes)

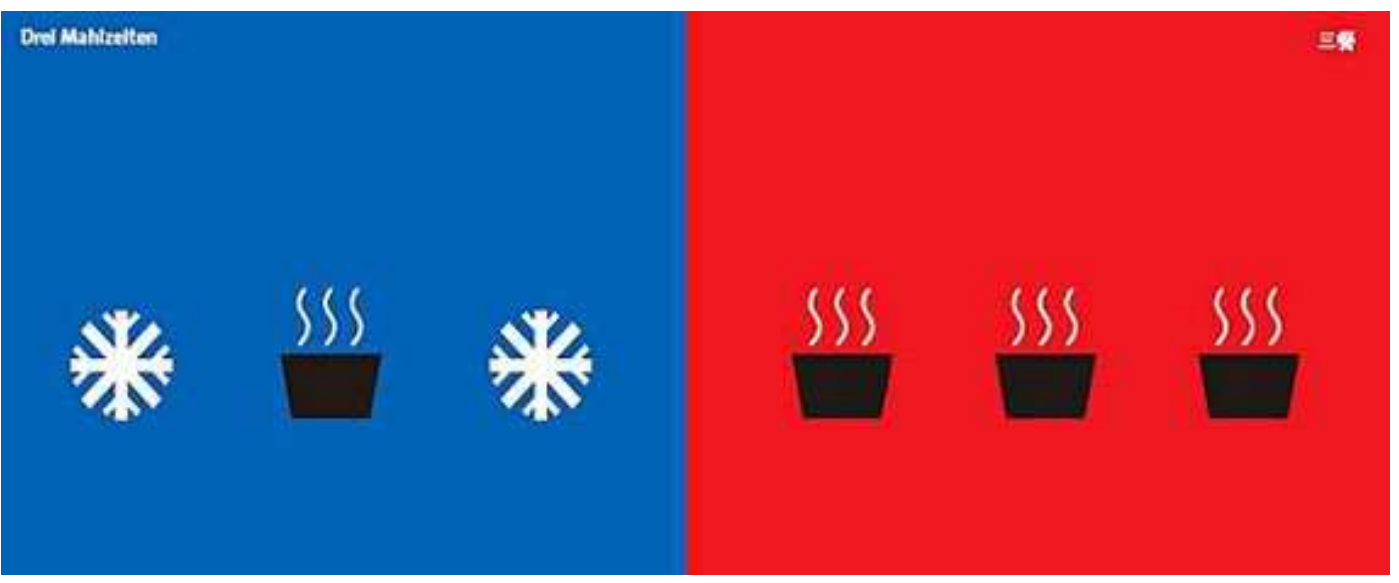

Ilustración 88 

